Ricardo Bragança de Vasconcellos Fontes

\title{
O disco intervertebral humano nas regiões cervical e lombar: morfologia e envelhecimento
}

Tese apresentada ao Departamento de Anatomia do Instituto de Ciências Biomédicas da Universidade de São Paulo para obtenção do título de Doutor em Ciências.

São Paulo

2011 
Ricardo Bragança de Vasconcellos Fontes

\title{
O disco intervertebral humano nas regiões cervical e lombar: morfologia e envelhecimento
}

\author{
Tese apresentada ao Departamento de \\ Anatomia do Instituto de Ciências Biomédicas \\ da Universidade de São Paulo para obtenção \\ do título de Doutor em Ciências. \\ Área de concentração: Ciências \\ Morfofuncionais \\ Orientador: Prof. Dr. Edson Aparecido Liberti \\ Versão original
}


DADOS DE CATALOGAÇÃO NA PUBLICAÇÃO (CIP)

Serviço de Biblioteca e Informação Biomédica do

Instituto de Ciências Biomédicas da Universidade de São Paulo

담eprodução total

Fontes, Ricardo Bragança de Vasconcellos.

$O$ disco intervertebral humano nas regiões cervical e lombar: morfologia e envelhecimento / Ricardo Bragança de Vasconcellos Fontes. -- São Paulo, 2011.

Orientador: Edson Aparecido Liberti.

Tese (Doutorado) - Universidade de São Paulo. Instituto de Ciências Biomédicas. Departamento de Anatomia. Área de concentração: Ciências Morfofuncionais. Linha de pesquisa: Disco intervertebral humano.

Versão do título para o inglês: The human intervertebral disc in the cervical and lumbar segments: morphology and aging.

Descritores: 1. Disco intervertebral 2. Morfologia (Anatomia) 3. Envelhecimento 4. Colágeno 5. Hominidae 6. Microscopia eletrônica de varredura I. Liberti, Edson Aparecido II. Universidade de São Paulo. Instituto de Ciências Biomédicas. Programa de PósGraduação em Ciências Morfofuncionais III. Título. 
UNIVERSIDADE DE SÄO PAULO

INSTITUTO DE CIÉNCIAS BIOMÉDICAS

\begin{abstract}
Candidato(a): $\quad$ Ricardo Bragança de Vasconcellos Fontes.
Titulo da Tese: $\quad$ O disco intervertebral humano nas regiões cervical e lombar: morfologia e envelhecimento.
\end{abstract}

Orientador(a):

Edson Aparecido Liberti.

A Comissão Julgadora dos trabalhos de Defesa da Tese de Doutorado, em sessão pública realizada a

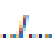
considerou

\title{
$\begin{array}{ll}\text { ( ) Aprovado(a) } & \text { ( ) Reprovado(a) }\end{array}$
}

\begin{tabular}{|c|c|}
\hline Examinador(a): & Assinatura: \\
\hline & (1) \\
\hline & Instituição: ..... \\
\hline Examinador(a): & Assinatura: .......... \\
\hline & Nome: ................... \\
\hline & Instituição: ........ \\
\hline Examinador(a): & Assinatura: ....................... \\
\hline & Nome: \\
\hline & Instituição: ....... \\
\hline Examinador(a): & Assinatura: ................ \\
\hline & Nome: .................. \\
\hline & Instituição: .......... \\
\hline Presidente: & Assinatura: \\
\hline & 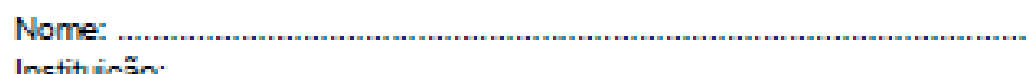 \\
\hline & Instituição: ................. \\
\hline
\end{tabular}


Prezado Senhor,

São Paulo, 14 de novembro de 2007.

\section{PARECER 811/CEP}

Atendendo sua solicitação, a Comissão de Ética em Pesquisas com Seres Humanos do ICB, em sua $80^{\circ}$ reunião realizada em 13.11.07, analisou o projeto de sua responsabilidade intitulado: "Repercussões morfológicas do envelhecimento nos discos intervertebrais cervicais e lombares humanos".

Informo a V.Sa. que, após análise e discussão o referido projeto foi aprovado por esta Comissão.

Lembramos que cabe ao pesquisador elaborar e apresentar a este Comitê, relatórios anuais (parciais ou final), de acordo com a resolução 196/06 do Conselho Nacional da Saúde, item IX.2 letra c.

O primeiro relatório deverá ser encaminhado à Secretaria deste CEP em 13 de novembro de 2008.

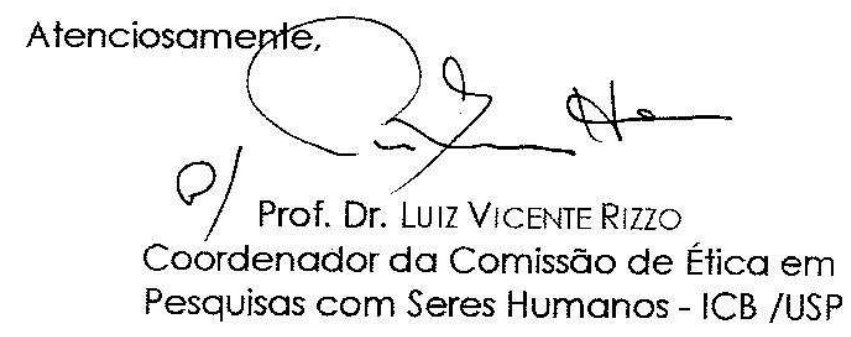

IImo. Sr.

RICARDO BRAGANÇA DE VASCONCELLOS FONTES

Departamento de Anatomia

Instituto de Ciências Biomédicas -USP 
Juntos passamos por uma mudança de país, duas residências médicas em neurocirurgia, uma preceptoria, um fellowship em cirurgia de coluna e um doutorado, além de incontáveis problemas insolúveis, cirurgias e noites de plantão. Eu buscava aprimorar-me em minha profissão; ela o fez por amor. 
No mês de Junho de 2011, durante a redação final desta tese, perdemos nossa querida Silvia. Ela era a voz da razão e o ponto de equilíbrio de nosso laboratório. Estive constantemente discutindo com ela o que eu acreditava ser seu maior defeito: a crença inabalável na bondade das pessoas. Isto se refletia em tudo que fazia, do cuidado com sua família à orientação de seus alunos, passando pelas aulas que ministrava e sua pesquisa. Apesar da saudade, sinto-me feliz por ter sido tocado, como tantos outros, por sua amizade e carinho.

Espero que todos nós possamos levar um pouquinho desse "defeito" da Silvia.

\section{A Um Ausente \\ Carlos Drummond de Andrade}

Tenho razão de sentir saudade, tenho razão de te acusar.

Houve um pacto implícito que rompeste e sem te despedires foste embora.

Detonaste o pacto.

Detonaste a vida geral, a comum aquiescência de viver e explorar os rumos de obscuridade sem prazo sem consulta sem provocação até o limite das folhas caídas na hora de cair. Antecipaste a hora.

Teu ponteiro enloqueceu, enloquecendo nossas horas. Que poderias ter feito de mais grave do que $o$ ato sem continuação, o ato em si, o ato que não ousamos nem sabemos ousar porque depois dele não há nada? Tenho razão para sentir saudade de ti, de nossa convivência em falas camaradas, simples apertar de mãos, nem isso, voz modulando sílabas conhecidas e banais que eram sempre certeza e segurança. Sim, tenho saudades. Sim, acuso-te porque fizeste o não previsto nas leis da amizade e da natureza nem nos deixaste sequer o direito de indagar porque o fizeste, porque te foste. 


\section{Agradecimentos}

Aos indivíduos envolvidos nesta pesquisa e suas famílias. Através de seu ato maior em hora tão dolorosa, espero que outros seres humanos possam se beneficiar dos resultados desta pesquisa.

Aos meus pais, Nilton e Mariza Fontes. Amor, honestidade, trabalho e determinação foram ensinados desde cedo: na teoria, na prática e com exemplos.

Ao meu grande amigo, orientador e "Mestre" Prof. Dr. Edson Aparecido Liberti. Nestes doze anos em que trabalhamos juntos, foram incontáveis as lições aprendidas. Sua humildade e disposição em ensinar o tornam exemplo perfeito não do título, mas do substantivo aqui tornado adjetivo: "professor".

To Dr. Vincent C. Traynelis, not only for the valuable input and comments on this project but also for the patience in the operating room, teachings in clinic and helping me become a better physician.

Ao meu amigo, colega neste projeto de pesquisa e "Mestre", Prof. Ms. Josemberg da Silva Baptista. Muitas horas passadas juntos na bancada e ainda muitas outras discutindo o trabalho, ao vivo ou via Skype, sempre com o vocabulário peculiar de nosso grupo de pesquisa.

Quem pode se dar ao luxo de contar não com um ou dois, mas um grupo dos melhores professores de Anatomia das universidades federais brasileiras para auxiliá-lo em seu doutorado? Aos nobres colegas e "Mestres", Prof. Dr. Carlos Eduardo Seyert, Prof. Dr. Dorival Terra Martini, Prof. Dr. Eduardo Beber, Profa. Dra. Flavia de Oliveira, Prof. Ms. Ricardo Eustáquio e Prof. Ms. William Paganini Mayer, não seria um “obrigado" a palavra mais apropriada para agradecê-los, mas o "valeu!!!!". Com este grupo, fica até fácil.

Ao grande companheiro de laboratório, "Truta" e "Mestre", Thiago Habacuque da Silva, pelas (muitas) horas passadas juntas no laboratório e pelo auxílio com as ressonâncias. 
A todos os colegas e "Mestres" de VQM e ICB: foram muitos os amigos feitos nestes doze anos de convivência. Para não omitir alguém, não cito nenhum nome aqui mas o de todos nas demais páginas desta tese. Há um pouco de cada um de vocês neste trabalho.

A todos os professores, técnicos e funcionários da Universidade de São Paulo envolvidos nesta tese: Prof. Dr. Said Rahnamaye Rabbani, Dr. Antonio Carlos Bloise Jr. e Dr. Hernán Joel Cervantes Rodríguez (Instituto de Física - USP); Dra. Rose Eli Grassi Rici (Faculdade de Medicina Veterinária e Zoologia - USP) e Sra. Marta Maria da Silva Righetti e Sr. Sebastião Boleta (Instituto de Ciências Biomédicas - USP).

Aos meus professores e colegas de faculdade na FMUSP, residência médica e preceptoria no Hospital das Clínicas da FMUSP e fellowship e residência na Rush University.

Às entidades que forneceram apoio financeiro a esta pesquisa: CAPES/CNPq (bolsa de doutorado), Rush University Medical Center e Cervical Spine Research Society (projeto de pesquisa).

Aos meus pacientes, razão de toda esta pesquisa.

Meu muito obrigado! 
A palavra "impossível" é uma expressão infeliz; nada de bom pode se esperar daqueles que a utilizam com frequência.

Thomas Carlyle (1795-1881) 


\section{Resumo}

Fontes RBV. O disco intervertebral humano nas regiões cervical e lombar: morfologia e envelhecimento [Tese (Doutorado em Ciências Morfofuncionais)]. São Paulo: Instituto de Ciências Biomédicas da Universidade de São Paulo; 2011.

Introdução: A doença degenerativa discal é um grave problema de saúde pública. As alterações morfológicas que caracterizam o envelhecimento normal confundem-se com aquelas consideradas patológicas, em parte devido ao desconhecimento de como a morfologia do disco se altera ao longo da vida, especialmente em nível cervical. O objetivo deste estudo foi elaborar um perfil destas alterações nos segmentos cervical e lombar. Materiais e Métodos: Discos intervertebrais humanos cervicais e lombares foram coletados em autópsia de 30 indivíduos assintomáticos: 15 jovens (<35 anos) e 15 idosos (>65 anos). A morfologia destes discos foi analisada com técnicas de avaliação macroscópica, ressonância magnética (RM), histologia, microscopia eletrônica de varredura (MEV) e imunohistoquímica para os colágenos de tipo I, II, III, IV, V, VI, IX e X. Resultados: Alterações degenerativas foram mais acentuadas nos discos de idosos, porém mesmo os discos jovens apresentaram degeneração significativa. A RM foi incapaz de detectar muitas dessas alterações. $\mathrm{O}$ anel fibroso possui lamelas oblíquas que se adensam com o envelhecimento. A análise histológica não revela um núcleo distinto em nível cervical, porém a MEV o demonstra claramente. As fibras colágenas sofreram intenso remodelamento e formam um padrão único para cada segmento, sendo colágeno tipo II o predominante nos discos humanos, com elevado conteúdo de colágeno IV nos discos cervicais e colágeno VI no anel e IX no núcleo lombar. Discussão: As alterações em nível cervical são semelhantes às do nível lombar com algumas peculiaridades: substituição cartilagínea é comum. Muitas das técnicas rotineiras de avaliação não conseguem detectar as alterações discais ultraestruturais únicas de cada segmento. A identificação de alterações colágenas próprias do envelhecimento normal permite identificar indivíduos que fogem deste padrão e fornecer bases para terapias de regeneração discal.

Palavras-chave: Disco intervertebral. Degeneração discal. Envelhecimento. Fotomicrografia. Microscopia de polarização. Microscopia eletrônica. 


\begin{abstract}
Fontes RBV. The human intervertebral disc in the cervical and lumbar segments: morphology and aging [Ph.D. thesis (Morphological Sciences)]. São Paulo: Instituto de Ciências Biomédicas da Universidade de São Paulo; 2011.
\end{abstract}

Introduction: Degenerative disc disease is a major public health problem. The morphological alterations of normal aging are frequently mistaken for those considered to be pathologic. This is at least in part due to our lack of understanding of how discs age in asymptomatic individuals, particularly in the cervical segment. Our aim is therefore to elaborate a morphological profile of these alterations in the cervical and lumbar levels. Materials and Methods: Human cervical and lumbar intervertebral discs were harvested at autopsy from 30 asymptomatic individuals: 15 young ( $<35$ years old) and 15 elderly ( $>65$ years old). The morphology of these discs was studied utilizing macroscopic technique, magnetic resonance (MR), histology, scanning electron microscopy (SEM) and immunohistochemistry against types I, II, III, IV, V, Vi, IX and X collagens. Results: Degenerative changes were more evident in discs of elderly individuals but even young discs displayed significant degeneration. MR could not detect several of these alterations. The annulus is composed of alternating oblique lamellae that get denser as they age. Histology frequently did not reveal a distinct nucleus in the cervical segment but SEM did. Collagen fibers underwent an extensive remodeling and form a pattern unique to each segment. Collagen II is the predominant collagen type in human discs, with important components of collagen IV in cervical discs and VI in the annulus and IX in the nucleus of lumbar specimens. Discussion: Alterations in cervical discs are similar to those in lumbar specimens but include some peculiarities: cartilaginous transformation is common. Several alterations could not be detected by MR or normal histology. Understanding how collagens are modified during normal aging enables the identification of individuals with abnormal ultrastructure and provides theoretical bases for regeneration therapies.

Key words: Intervertebral disc. Intervertebral disc degeneration. Aging. Photomicrography. Microscopy, polarization. Microscopy, electron. 


\section{Lista de llustrações}

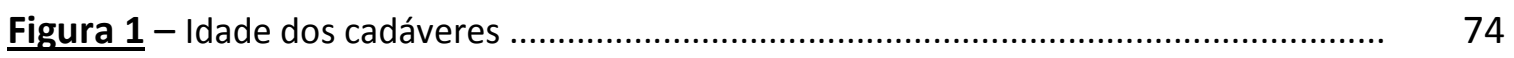

Figura 2 - Altura dos cadáveres ..........................................................................

Figura 3 - Peso dos cadáveres ........................................................................ 75

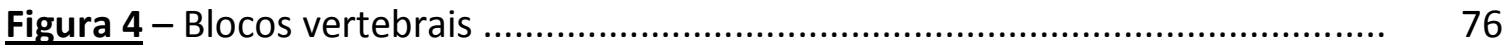

Quadro 1 - Classificação morfológica de Thompson ............................................. 78

Quadro 2 - Anticorpos utilizados no estudo .................................................... 82

Figura 5 - Análise gráfica no Image J................................................................ 86

Figura 6 - Comparação de imagens de RM com macroscopia - espécime pouco degenerado .................................................................................... 90

Figura 7 - Comparação de imagens de RM com macroscopia - discrepância entre segmentos

Figura 8 - Comparação de imagens de RM com macroscopia - espécime com degeneração acentuada

Figura 9 - Avaliação macroscópica segundo Thompson - extremos de graduação.

Figura 10 - Avaliação macroscópica segundo Thompson - exemplos cervicais ........

Figura 11 - Avaliação macroscópica segundo Thompson - exemplos lombares .....

Figura 12 - Graduações de Thompson - avaliação entre grupos

Figura 13 - Discos cervicais, HE, região anterior. Espécimes com baixo grau de degeneração

Figura 14 - Disco cervical, HE, região anterior em orientação coronal. Disposição oblíqua

Figura 15 - Discos cervicais, HE, região anterior. Espécimes com elevado grau de degeneração

Figura 16 - Discos cervicais, HE, região central. Progressão presumida das alterações degenerativas

Figura 17 - Discos cervicais, $\mathrm{HE}$, região posterior do anel. Espécimes com baixo grau de degeneração

Figura 18 - Discos cervicais, HE, região posterior do anel. Espécimes com elevado grau de degeneração 
Figura 19 - Discos cervicais, HE. Características classicamente associadas com degeneração: placa vertebral e condrócitos

Figura 20 - Discos cervicais, HE. Discrepância entre caracteres histológicos degenerativos e classificação de Thompson

Figura 21 - Discos cervicais, Picro-Sirius, região anterior. Espécimes com baixo grau de degeneração

Figura 22 - Discos cervicais, Picro-Sirius, região anterior. Espécimes com elevado grau de degeneração

Figura 23 - Discos cervicais, Picro-Sirius, região posterior. Espécimes com baixo grau de degeneração

Figura 24 - Discos cervicais, Picro-Sirius, região posterior. Espécimes com elevado grau de degeneração

Figura 25 - Discos cervicais, fibras elásticas. Grupo Jovem

Figura 26 - Discos cervicais, fibras elásticas. Grupo Idoso

Figura 27 - Discos cervicais, fibras elásticas. Único exemplar do Grupo Idoso com presença significativa de fibras elásticas

Figura 28 - Discos cervicais, fibras elásticas, Grupo Idoso. Presença de fibras elásticas nos ligamentos longitudinais

Figura 29 - Discos lombares, HE, região anterior. Espécimes com baixo grau de degeneração

Figura 30 - Discos lombares, HE, região anterior. Espécimes com elevado grau de degeneraçao

Figura 31 - Discos lombares, HE, região central. Degeneração nuclear e correlação com graduação de Thompson

Figura 32 - Discos lombares, HE, região posterior. Espécimes com baixo grau de degeneração

Figura 33 - Discos lombares, HE, região posterior. Espécimes com elevado grau de degeneração

Figura 34 - Discos lombares, HE. Características degenerativas típicas nos discos do segmento lombar 
Figura 35 - Discos lombares, coloração Picro-Sirius, região anterior. Espécimes com baixo grau de degeneração

Figura 36 - Discos lombares, coloração Picro-Sirius, região anterior. Espécimes com elevado grau de degeneração

Figura 37 - Discos lombares, coloração Picro-Sirius, região central. Espécimes com baixo grau de degeneração

Figura 38 - Discos lombares, coloração Picro-Sirius, região central. Espécimes com elevado grau de degeneração

Figura 39 - Discos lombares, coloração Picro-Sirius, região posterior. Espécimes com baixo grau de degeneração

Figura 40 - Discos lombares, coloração Picro-Sirius, região posterior. Espécimes com elevado grau de degeneração

Figura 41 - Discos lombares, fibras elásticas, região anterior. Espécimes de GJ agrupados conforme o grau de degeneração

Figura 42 - Discos lombares, fibras elásticas, região anterior. Espécimes de GI agrupados conforme o grau de degeneração

Figura $\mathbf{4 3}$ - Discos lombares, fibras elásticas, região central. Espécimes de $\underline{\text { GJ }}$ agrupados conforme o grau de degeneração

Figura 44 - Discos lombares, fibras elásticas, região central. Espécimes de $\underline{\text { GI }}$ agrupados conforme o grau de degeneração

Figura 45 - Discos lombares, fibras elásticas, região posterior. Espécimes de GJ agrupados conforme o grau de degeneração

Figura 46 - Discos lombares, fibras elásticas, região posterior. Espécimes de $\underline{\text { GI }}$ agrupados conforme o grau de degeneração

Figura 47 - Discos cervicais, MEV, espécimes de GJ

Figura 48 - Discos cervicais, MEV, espécimes de $\underline{\text { GI }}$

Figura 49 - Discos lombares, MEV, espécimes de $\underline{\mathbf{G J}}$.....

Figura 50 - Discos cervicais, MEV, espécimes de $\underline{\mathbf{G I}}$

Figura 51 - Expressão imuno-histoquímica dos diferentes tipos de colágeno ........

Figura 52 - Quantificação da marcação por IHC, espécimes cervicais .

Figura 53 - Quantificação da marcação por IHC, espécimes lombares 
Figura 54 - Distribuição dos tipos de colágeno por setor discal, com resultados da

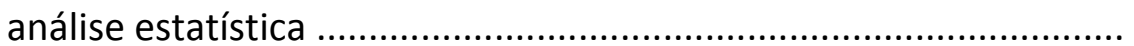




\section{Lista de Tabelas}

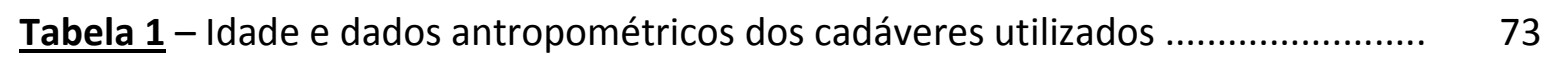

Tabela 2 - Resumo das medidas de imuno-histoquímica ...................................... 85

Tabela 3 - Graduação de Thompson ............................................................. 92 


\section{Lista de Abreviaturas e Siglas}

\begin{tabular}{|c|c|}
\hline $\mathrm{AF}$ & - Anel fibroso \\
\hline ANOVA & - Analysis of variance \\
\hline Arg & - Arginina \\
\hline BDNF & - Brain-derived growth factor \\
\hline CervAnt & - Cervical anterior \\
\hline CervPost & - Cervical posterior \\
\hline CGRP & - Calcitonin gene-related peptide \\
\hline $\mathrm{cm}$ & - centímetro(s) \\
\hline CML & - N-carboximetil-lisina \\
\hline $\mathrm{DAB}$ & - Diaminobenzidina \\
\hline DDD & - Doença degenerativa discal \\
\hline EDTA & - Ácido etilenodiaminotetraacético \\
\hline Et al. & - Et alii \\
\hline G & - Guanina \\
\hline GAG & - Glicosaminoglicana \\
\hline GI & - Grupo idoso \\
\hline GJ & - Grupo jovem \\
\hline Gln & - Glutamina \\
\hline $\mathrm{HE}$ & - Hematoxilina e eosina \\
\hline IFN- $\gamma$ & - Interferon-gama \\
\hline ICB-USP & - Instituto de Ciências Biomédicas da Universidade de São Paulo \\
\hline IGF-1 & - Insulin-like growth factor-1 \\
\hline $\mathrm{IHC}$ & - Imuno-histoquímica \\
\hline IASP & - International Association for the Study of Pain \\
\hline IL-X & - Interleucina-número (IL-1, IL-6, IL-8, etc.) \\
\hline IL-XR & - Receptor para interleucina-número (IL-1R, IL-6R, etc.) \\
\hline $\mathrm{Kb}$ & - Kilobase \\
\hline $\mathrm{Kg}$ & - Kilograma(s) \\
\hline LLA & - Ligamento longitudinal anterior \\
\hline LLP & - Ligamento longitudinal posterior \\
\hline
\end{tabular}




$\begin{array}{ll}\text { LombAnt } & \text { - Lombar anterior } \\ \text { LombNuc } & \text { - Lombar, núcleo } \\ \text { LombPost } & \text { - Lombar posterior } \\ \text { M } & \text { - Molar } \\ \text { MMP } & \text { - Matrix metalloproteinase } \\ \text { N } & \text { - Normal } \\ \text { NP } & \text { - Não-polarizada } \\ \text { NGF } & \text { - Nerve growth factor } \\ \text { NP } & \text { - Núcleo pulposo } \\ \text { ODI } & \text { - Oswestry Disability Index } \\ \text { P } & \text { - Polarizada } \\ \text { PG } & \text { - Proteoglicana } \\ \text { PIB } & \text { - Produto Interno bruto } \\ \text { PBS } & \text { - Phosphate-buffered saline } \\ \text { RGB } & \text { - Red-green-blue } \\ \text { RM } & \text { - Ressonância magnética } \\ \text { VLRP } & \text { - Small leucine-rich proteoglycan } \\ \text { T } & \text { - Timidina } \\ \text { TGF- } \beta & \text { - Transforming Growth Factor-beta } \\ \text { TIMP } & \text { - Grau de Thompson - Th1, Th2... } \\ \text { TNF- } \alpha & \text { - Tissue-inhibitors-of-matrix-metalloproteinases } \\ \text { VIP } & \text { - Tumor necrosis factor-alpha } \\ \text { VIine intestinal peptide }\end{array}$




\section{Sumário}

1 Introdução e revisão de literatura ................................ 21

1.1 Introdução e considerações epidemiológicas ........................... 22

1.2 Dor localizada à região da coluna vertebral ............................ 25

1.3 Primeiras descrições anatômicas do disco intervertebral ......... $\quad 26$

1.4 Conceitos embriológicos básicos ........................................... 28

1.5 A descrição fundamental do disco intervertebral ..................... 31

1.6 Adições modernas à biologia do disco intervertebral ............... 34

1.6.1 Hidratação do disco intervertebral e conteúdo de proteoglicanas ..... $\quad 35$

1.6.2 O sistema de fibras colágenas no disco intervertebral - "perfil

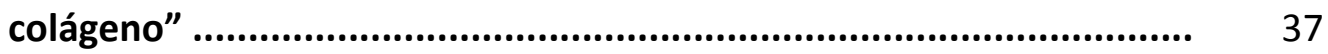

1.6.3 Desenvolvimento e degeneração discal ............................................. 43

1.6.4 Fisiopatologia da doença degenerativa discal ..................................... 51

1.6.5 Genética e doença degenerativa discal ............................................ 55

1.7 Características e deficiências de diferentes modelos de estudo da degeneração discal: in vitro, in vivo, por imagem e morfológicos

1.8 Particularidades dos discos do segmento cervical .................... 63

1.9 Contribuições brasileiras ao estudo da degeneração discal .... 67

2 Objetivos e hipóteses ............................................ 69

3 Materiais e Métodos ................................................. 71

3.1 Obtenção e fixação dos espécimes ............................................ 72

3.2 Avaliação por ressonância magnética ...................................... 76

3.3 Análise morfológica e descalcificação ..................................... 77

3.4 Microscopia de luz ................................................................ 79

3.5 Microscopia eletrônica de varredura ....................................... $\quad 80$

3.6 Imuno-histoquímica ................................................................. 80 
3.7 Quantificação da marcação imuno-histoquímica ....................... 83

3.8 Tratamento estatístico .......................................................... 87

4 Resultados ........................................................... 88

4.1 Ressonância magnética ............................................................ 89

4.2 Avaliação macroscópica ....................................................... 91

4.3 Microscopia de luz .............................................................. 97

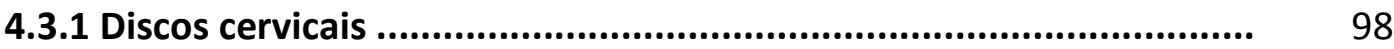

4.3.1.1 Organização geral dos discos- HE ......................................... 98

4.3.1.2 Feixes conjuntivos - Picro-Sirius ............................................. 106

4.3.1.3 Fibras elásticas .................................................................. 110

4.3.2 Discos lombares ........................................................................... 116

4.3.2.1 Organização geral dos discos - HE ......................................... 116

4.3.2.2 Feixes conjuntivos - Picro-Sirius ............................................. 123

4.3.2.3 Fibras elásticas ..................................................................... 129

4.4 Microscopia eletrônica de varredura ....................................... 135

4.5 Imuno-histoquímica ............................................................... 139

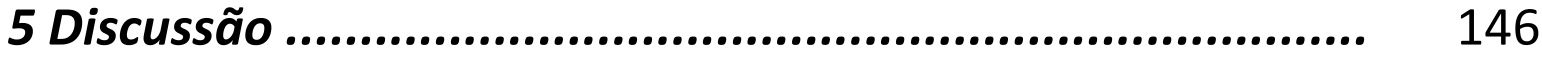

6 Conclusões ............................................................. 164

Referências ........................................................... 166

Anexos

Anexo A - Resumo de alocação dos cadáveres .............................. $\quad 184$

Anexo B - Imagens de microscopia produzidas e avaliadas ........... $\quad 185$ 
1 Introdução e revisão de literatura 


\subsection{Introdução e considerações epidemiológicas}

"The clinical picture of backache has often been an enigma to the medical profession". É assim que Coventry et al. iniciam o mais importante estudo sobre a estrutura do disco intervertebral em $1945^{1}$. A despeito de avanços tecnológicos e de múltiplas abordagens para seu estudo nos últimos 65 anos, esta frase permanece atual e tanto a cervical como a lombalgia, importantes problemas de saúde pública. A dor referida à região da coluna vertebral é hoje uma das queixas médicas mais frequentes: estima-se que de 70 a $80 \%$ da população adulta passe por um episódio clinicamente relevante deste problema ao longo da $v \operatorname{vida}^{2,3}$. Estudos adequados de incidência e prevalência de dor referida à região cervical (doravante aqui denominada apenas cervicalgia) ou lombar (lombalgia) são de condução extremamente complexa: os resultados são ultimamente afetados por inúmeros fatores, como geografia (país desenvolvido ou em desenvolvimento, área urbana ou rural), população (idade, tabagismo, doenças associadas, uso de analgésicos, situação ocupacional, sedentarismo), características de atendimento médico (por médico generalista ou especialista, unidade básica de atendimento ou hospital terciário) ou ainda de acordo com a maneira que o estudo afere esta informação (modelo prospectivo ou retrospectivo, reportado pelo paciente, seu médico ou outro profissional de saúde) $)^{2}$.

Um grande número de estudos dedicou-se a estimar a prevalência de cervical e/ou lombalgia em diferentes populações - por exemplo, Strine e Hootman calcularam a prevalência de três meses de cervicalgia ou lombalgia na população americana em $31 \%$ no ano de $2002^{4}$. Possivelmente mais útil é o cálculo da incidência, uma vez que estas queixas podem se tornar crônicas, porém tal cálculo é consideravelmente mais difícil de ser feito. Assim, um número bem menor de estudos seguiu populações previamente assintomáticas e calculou a incidência ao longo de determinado período de tempo. Em virtude dos fatores expostos no parágrafo anterior, a incidência anual de lombalgia na população geral reportada na literatura varia imensamente: valores desde 4 até $93 \%$ podem ser encontrados 5,6 . Divergências desta natureza são creditadas a diferentes perfis destas 
subpopulações com relação a fatores de risco, como fumo e situação ocupacional, por exemplo ${ }^{7}$. Entretanto, mesmo em subpopulações com motivos para esconder esta queixa, a incidência de lombalgia é significativa: ao avaliar soldados de forças especiais do exército americano que poderiam ter suas promoções negadas se reportassem lombalgia, Carragee e Cohen relataram que $84 \%$ dos mesmos confirmaram ter passado por pelo menos um episódio de lombalgia em um período de 18 meses afastados de combate, e em $12 \%$ dos mesmos esta queixa foi classificada como "severa" baseado no Oswestry Disability Index $(O D I)^{8}$. Ainda assim, mesmo as taxas de incidência mais baixas resultam em elevada prevalência deste problema na população. Em uma revisão recente, Walker identificou 30 estudos epidemiológicos com metodologia apropriada publicados entre 1966 e 1998. A partir destes estudos, pôde calcular a prevalência pontual em 12 a 33\%, prevalência de um ano em 22 a $65 \%$ e prevalência para a vida inteira em 11 a $84 \%{ }^{9}$. A conclusão que se pode obter a partir dos estudos epidemiológicos é que a incidência de qualquer tipo de lombalgia durante um período de 1-2 anos é muito alta; por outro lado, o risco de este ser um episódio prolongado e necessitar assistência médica mais elaborada é bem menor².

O número de estudos epidemiológicos que se refere à cervicalgia é muito menor. Uma recente meta-análise detectou apenas dezessete estudos adequados entre os anos 1980$2006^{10}$. Mesmo assim, o padrão de grandes variações se repete: Bot et al. analisaram prospectivamente um ano de atendimento nos hospitais gerais da Holanda, para um total de mais de 1.500 .000 consultas médicas e chegaram a uma incidência de 23,1 episódios por 1000 pessoas.ano (primeiro episódio de cervicalgia) ${ }^{11}$. No outro extremo, Stahl et al. reportaram uma incidência muito maior, de 213 novos casos de cervicalgia por 1000 pessoas.ano, calculada a partir de questionários respondidos por pacientes em unidades básicas de saúde do Canadá ${ }^{12}$. Estas taxas são em geral menores que as de lombalgia, porém também resultam em prevalência bastante significativa. Estima-se que a prevalência de um ano para cervicalgia na população adulta oscile ao redor de $20 \%$, enquanto que cerca de $67 \%$ da população apresenta ao menos um episódio clinicamente relevante de cervicalgia ao longo da vida ${ }^{2,13,14}$. 
O impacto econômico destas duas condições sobre a sociedade moderna é imenso. Analisando uma coorte de 1146 pacientes afastados do trabalho por pelo menos 28 dias, dentro de um período de recrutamento de um ano em 5 dos 21 hospitais regionais da Suécia, Hansson e Hansson calcularam custos diretos e indiretos de cervical e lombalgia ${ }^{15}$. Os custos diretos, incluindo procedimentos percutâneos e cirúrgicos para tratamento, representaram apenas $7 \%$ dos custos totais ao final de dois anos de seguimento. Todavia, a perspectiva de retorno ao trabalho foi muito baixa: ao final deste seguimento de dois anos, $28 \%$ deles não havia retornado ao trabalho. Sendo assim, a maior parcela dos custos decorreu de perdas indiretas, como pagamento de benefícios e dias perdidos de trabalho. Ao final do estudo, estes 1146 pacientes haviam levado a perdas de mais de 30 milhões de euros; extrapolando-se para o número de pessoas afastadas pelas mesmas causas naquele país durante o ano de 2001, pode-se calcular que os custos totais para tratamento de cervical e lombalgia chegaram a $1 \%$ do produto interno bruto (PIB) da Suécia ${ }^{15}$. Wieser et al. realizaram análise semelhante na Suiça exclusivamente para lombalgia: partiram de um grupo aleatório de pouco mais de 2500 habitantes, dos quais a metade apresentara lombalgia no último mês. Destes, 350 permaneciam em tratamento para lombalgia. Analisando os custos envolvidos no tratamento desta pequena amostra, Wieser et al. estimaram os custos diretos de tratamento de lombalgia na Suiça inteira em 2,6 bilhões de euros ou $6,1 \%$ de todo o gasto nacional em saúde. Quanto aos custos indiretos, estes ficam entre 2,2 e 4,1 bilhões de euros, consumindo assim 1,6 a 2,3\% do PIB suiço no ano de $2005^{16}$. A maior parcela destes custos indiretos seriam decorrentes de "presenteísmo", um neologismo derivado de absenteísmo e que denota as perdas de produtividade daqueles trabalhadores que comparecem ao trabalho, porém sintomáticos ${ }^{16}$.

Há uma base de dados bem menor relativa aos custos societários exclusivamente da cervicalgia quando comparado com a lombalgia. Cassidy e Coté analisaram oito trabalhos publicados recentemente que lidavam com os custos populacionais da cervicalgia ${ }^{17}$. Destes oito, apenas um aplicava-se à cervicalgia de etiologia degenerativa em população previamente assintomática; a grande maioria tratava de efeitos crônicas de lesões cervicais traumáticas do tipo "chicote" - na Holanda, em 1996, Borghouts et al. avaliaram os custos diretos e indiretos decorrentes de cervicalgia. Mais uma vez, os custos indiretos (US\$ 527 
milhões - 77\% do total) superaram em muito os custos diretos (US\$ 160 milhões - 23\%). Estes valores corresponderam a $1 \%$ dos gastos em saúde e $0,1 \%$ do PIB da Holanda naquele ano ${ }^{18}$.

\subsection{Dor localizada à região da coluna vertebral}

As queixas de cervical ou lombalgia podem ser divididas em dois grandes grupos, de acordo com seu componente predominante: dores irradiadas ou localizadas. Estas queixas, quando associadas aos sinais verificados no exame físico, entram chaves diagnósticas distintas. 0 topodiagnóstico é facilitado nas dores com irradiação através da correlação com dermátomos e outros dados de exame neurológico, como fraqueza de grupos musculares específicos ou alterações de reflexos. Identificada a(s) raiz(es) acometida(s), o diagnóstico etiológico buscará identificar uma causa funcional (nas quais se incluem as de origem metabólica, infecciosa, inflamatória e paraneoplásica, entre outras) ou anatômica (dentre estas, as diversas síndromes compressivas e parte das traumáticas) ${ }^{19}$.

Em contraste com as dores irradiadas, o exercício diagnóstico das dores localizadas é mais difícil. Esta dor localizada é por vezes referida na literatura como "mecânica" ou "axial" que não deve ser associada automaticamente com doença degenerativa discal ou outro mecanismo etiológico, pois referem-se apenas às características clínicas da dor ${ }^{20,21}$. No presente texto, o termo "dor localizada" será utilizado, referindo-se à dor que não se irradia para as extremidades e restringe-se às regiões occipital, cervical posterior e interescapular. Esta cervicalgia pode ser uni- ou bilateral e estender-se até as regiões temporal e parietal, caracterizando-se ainda por restrição de movimento do pescoço ${ }^{20}$. Na região lombar a definição é similar - a região afetada consiste na região lombar, glútea e porção posterior da coxa, uni- ou bilateral, com piora da dor na posição sentada ou em pé ${ }^{22,23}$. Apesar de muitas vezes relacionado à doença degenerativa vertebral, este tipo de dor pode ser causado por diversas condições: acometimento vertebral por infecções, neoplasias ou fraturas (sejam elas traumáticas ou patológicas). De fato, a origem mais frequente de dor mecânica é 
miofascial, que geralmente ocorre no contexto de algum tipo de atividade física causando macro- ou micro-traumas do aparato musculoligamentar ao redor da coluna vertebral ${ }^{24}$. Usualmente autolimitados, a repetição destes microtraumatismos pode levar a hiperatividade anormal e crônica da junção neuromuscular em determinados setores do músculo - por sua vez gerando isquemia local e dor. Há extensa comprovação experimental desta teoria e imagina-se também que este controle anormal da unidade motora está envolvido pelo menos parcialmente na geração de dor de outras etiologias ${ }^{23-25}$. Entretanto, quando causas mais óbvias são excluídas, frequentemente a investigação diagnóstica aponta na direção da chamada doença degenerativa discal (DDD). Como se verá adiante, uma das maiores dificuldades para elucidar a DDD é compreender o que é envelhecimento normal e o que é uma situação patológica. Com este objetivo, revisaremos a anatomia e embriologia normais do disco intervertebral, para ultimamente conceituarmos degeneração e DDD, tratando de sua fisiopatologia.

\subsection{Primeiras descrições anatômicas do disco intervertebral}

As características estruturais básicas dos discos intervertebrais humanos, e mesmo algumas características histológicas, já eram conhecidas dos anatomistas do século XIX - os egípcios conheciam os discos intervertebrais e Vesalius os menciona sucintamente. Entretanto, pertence a Hubert von Luschka a pioneira descrição detalhada do disco intervertebral que sobreviveu até nossos dias. Luschka publicou uma série de trabalhos anatômicos entre 1852 e 1858 em que delineou a estrutura do disco intervertebral, as placas vertebrais e elucidou sua natureza cartilagínea ${ }^{26}$. Por outro lado, descreveu o disco intervertebral como uma articulação sinovial do tipo plana: o que ele interpretou como a cavidade central corresponde ao núcleo pulposo em crianças, além de erroneamente descrever um revestimento epitelial para esta cavidade. Ainda assim, ele inadvertidamente descreveu pela primeira vez uma das alterações ulteriormente identificadas como sendo características do envelhecimento: Luschka observou que a sua suposta cavidade do disco diminuía em altura com a idade até se tornar apenas uma fissura em idosos ${ }^{26}$. 
Uma descrição mais apropriada do disco surgiu no início do século XX. Em 1905 Testut já descreveu a coluna vertebral como sendo composta por 33 ou 34 vértebras articulando-se entre si através de um ligamento interósseo ("ligament interosseux") - apesar de denominálo um ligamento, Testut demonstrou o disco intervertebral como um menisco composto por duas partes: um anel periférico fibrocartilagíneo e um núcleo gelatinoso. Detalhando o anel fibroso (AF) típico do segmento lombar, Testut descreveu a organização em lamelas das fibras oblíquas do AF, a alternância de orientação entre estas lamelas, a diferença de altura entre os diferentes setores do disco (mais alto na região do núcleo) e por fim, até a presença de vasos e ramos nervosos na periferia do anel fibroso. Testut ainda teceu comentários acerca de uma maior celularidade nos núcleos de crianças até a idade de oito anos, quando comparados com indivíduos de sessenta ou mais anos, indicando que alterações próprias do envelhecimento certamente já eram conhecidas naquela época ${ }^{27}$. Quanto ao núcleo pulposo, Testut já mantinha que este era derivado de uma massa celular no embrião que praticamente desaparece antes do nascimento, indicando que a noção de origens embrionárias distintas para o anel e o núcleo já era corrente e amplamente aceita naquela época ${ }^{27,28}$.

Poirier et al., em 1908, repetiram basicamente a mesma descrição de Testut porém abandonaram o termo ligamento e, ao descrever o disco pela primeira vez como uma anfiartrose, adotou o termo "disques intervertébreaux". Poirier et al. mencionaram também a presença de fibras elásticas no disco, afirmando, entretanto, que estas aumentam em número quanto mais próximas do núcleo ${ }^{29}$. As descrições anatômicas até o final da década de 1930 permanecem basicamente as mesmas; por exemplo, Chiarugi em 1926 manteve o termo "fibrocartilagini intervertebrali", além de reconhecer a presença de fibras elásticas no interior do anel fibroso ${ }^{28-30}$. Nos anos seguintes houve avanço principalmente no estudo da inervação dos ligamentos longitudinais e porções mais superficiais do anel fibroso, como os trabalhos de Hovelacque e Roofe, baseados na pioneira descrição de Luschka do chamado ramo nervoso sinovertebral, hoje listado na Terminologia Anatômica apenas como ramo meníngeo ${ }^{31-33}$. Ainda digno de nota foi o trabalho radiológico de Schmorl e Junghanns, 
principalmente focado no corpo vertebral e suas alterações degenerativas, mas novos conceitos acerca da estrutura discal propriamente dita haveriam de aguardar as três publicações clássicas de Coventry et al., em $1945^{26,32-34}$.

\subsection{Conceitos embriológicos básicos}

Os primeiros comentários acerca da origem embrionária dos discos intervertebrais foram novamente de Luschka; este sugeriu mas não demonstrou um papel da notocorda na sua formação ${ }^{26}$. Em 1859, Kölliker foi o primeiro a detectar células derivadas da notocorda no interior do disco intervertebral, enquanto Löwe mais tarde chegou a afirmar que todo o núcleo pulposo era formado a partir da notocorda ${ }^{35,36}$. A opinião de Löwe, entretanto, não foi amplamente aceita naquele momento. Mesmo nas últimas décadas do século XIX, importantes patologistas como Virchow e Dursy sustentavam que o núcleo pulposo era, na verdade, formado a partir da degeneração do anel fibroso devido à vascularização insuficiente ${ }^{37,38}$. O valor da teoria de Virchow e Dursy é que já se reconhecia naquela época a nutrição deficiente na região central do disco; a conclusão equivocada, entretanto, só começou a ser desfeita no início do século XX: Bardeen, em 1905, descreveu o processo básico de formação do disco intervertebral ${ }^{39}$. Adições importantes foram feitas por Kollmann e Minot, e coube finalmente a Keyes e Compere sumarizar estes conhecimentos e, adicionando dados de suas próprias pesquisas, chegar à teoria de desenvolvimento do disco intervertebral como nós a conhecemos ${ }^{40-42}$.

O período de desenvolvimento da coluna vertebral pode ser dividido em três fases: mesenquimal, cartilagíneo e ósseo. Ao redor de quatro semanas de vida intrauterina, células mesenquimais derivadas dos esclerótomos deslocam-se até uma posição ao redor da notocorda. Estas células agrupam-se então em uma coluna segmentada; estes setores são separados entre si pelas artérias segmentares. Esta segmentação é completa apenas na porção lateral, onde os nervos e artérias segmentares se desenvolvem - na região central, esta nunca chega a acontecer por completo. As células mesenquimais passam a se 
concentrar em regiões específicas desta coluna, onde em cada segmento são identificados dois setores: uma porção cefálica, com organização celular mais frouxa, e outra porção caudal, com maior densidade celular. Neste momento, as células mais próximas das artérias segmentares desenvolvem-se mais rapidamente, fato atribuído por Keyes e Compere à melhor nutrição destas áreas: estas são a porção caudal da região densa e a região cefálica da porção frouxa imediatamente caudal. Em virtude da proliferação acentuada destes setores, estes setores de dois somitos diferentes fundem-se e tornam-se o primórdio ou anlage do corpo vertebral - a esta teoria deu-se o nome de resegmentação, sugerida pela primeira vez por Remak ${ }^{43}$. Remak ainda postulou que, desta maneira, a segmentação final das vértebras (derivadas de dois esclerótomos diferentes) não corresponderia à mesma segmentação dos músculos paraespinhais (derivados, em cada segmento, de um único dermatomiótomo), permitindo assim que estes últimos estivessem ligados a duas vértebras diferentes e pudessem movê-las. Ainda que extremamente elegante, não há como comprovar a teoria de $\operatorname{Remak}^{44}$. A resegmentação ocorre apenas na região central, enquanto que na porção lateral a segmentação original permanece, de modo que os pares de elementos posteriores, incluindo os pedículos, são derivados apenas da densa porção caudal de um único somito e depois se fundem ao corpo vertebral ${ }^{42,43,45-47}$.

A porção cranial da região densa persiste e, mais uma vez atribuído por Keyes e Compere à nutrição deficiente deste setor, torna-se o disco intervertebral, especificamente $\mathrm{o}$ anel fibroso - correlacionando ainda com o fato de permanecer uma estrutura essencialmente avascular durante o restante da vida. Há alguma divergência sobre qual setor do esclerótomo ultimamente forma o disco - autores como Christ e Wilting sustentaram que o disco é derivado da frouxa porção caudal do somito ${ }^{45}$. De qualquer maneira, com a hiperplasia das células que formam o corpo vertebral, a notocorda desaparece desta região, permanecendo apenas na região central pouco vascularizada, distante das artérias intersegmentares - ulteriormente este resquício da notocorda irá compor parte do núcleo pulposo. Estas células diferenciam-se inicialmente em fibroblastos e aderem às superfícies dos corpos vertebrais acima e abaixo ${ }^{42}$. Muito mais que mero remanescente embriológico, estas células derivadas da notocorda possuem papel ativo no desenvolvimento do disco. Estudos experimentais em que a notocorda foi removida de embriões de aves 
demonstraram a formação de arcos neurais a partir do mesênquima axial que deveria originar os corpos vertebrais e discos ${ }^{45-48}$.

Após a sexta semana, centros de condrogênese já surgiram nas vértebras, dando início à segunda fase da embriogênese vertebral. Na décima semana, as fibras do anel fibroso já estão mais bem definidas, e podem ser vistas inclusive ao redor do núcleo pulposo e inserindo-se no corpo vertebral acima e abaixo. É esta inserção que Keyes e Compere acreditam corresponder no adulto à placa vertebral, e portanto deriva completamente do anel fibroso e não do núcleo pulposo ${ }^{42}$. Estes mesmos autores reconheceram que há mais tecido derivado de notocorda ao nascimento em um único disco do que na notocorda inteira na sétima semana de gestação; portanto, inferem que há proliferação de células derivadas da notocorda pelo menos até o nascimento. Após este momento, identificaram a proliferação celular na região central do disco como sendo primordialmente de natureza fibrosa e oriunda da placa vertebral, correlacionada assim com a diminuição e gradual desaparecimento do material nuclear ao longo da vida adulta. Por final, segue o período de ossificação, completando-se apenas aos 8-9 anos de idade ${ }^{42}$.

De suma importância é esta noção introduzida por Keyes e Compere que o núcleo pulposo não é uma estrutura apenas vestigial mas sim altamente complexa e especializada, resultante de um elaborado processo de embriogênese. Estas teorias introduzidas na primeira metade do século XX permanecem até hoje em seus conceitos básicos com pequenas correções, por exemplo, com a introdução da idéia de degeneração de pelo menos parte das células da notocorda e não exclusivamete migração para o espaço intervertebral ${ }^{49}$. Ulteriores adições a estes mecanismos se fizeram basicamente no campo da genética e biologia molecular. A sequência da embriogênese do disco estava delineada, permitindo o aparecimento dos primeiros estudos focalizando primordialmente a degeneração discal ${ }^{47}$. 


\subsection{A descrição fundamental do disco intervertebral}

Certamente vital para o entendimento da anatomia normal e patológica do disco intervertebral é a trilogia de trabalhos de Coventry et al. publicada em 1945; até hoje ela é reconhecida como tal ${ }^{1,50-53}$. É a primeira série anatômica detalhada desde a macro- até a microscopia do quinto disco lombar de um número significativo (88) de cadáveres de todas as faixas etárias. Estes trabalhos sofrem de defeitos inerentes aos trabalhos morfológicos daquela época, como generalizações impróprias (ao afirmar, por exemplo, que todos os discos de diferentes segmentos vertebrais são iguais) e limitações tecnológicas; ainda assim, é constantemente citado nos estudos mais atuais de degeneração discal pelo seu pioneirismo e achados histológicos ainda relevantes ${ }^{53}$.

Coventry et al. obtiveram 88 discos L5S1 através de autópsias de rotina, removidos de indivíduos de 10 meses a 79 anos de idade ${ }^{1}$. Após a obtenção de radiografia lateral, o espécime era seccionado no plano sagital mediano e submetido a fixação, descalcificação e ulterior estudo por técnicas histológicas de hematoxilina e eosina (HE), Van Gieson e De Galantha. Estes autores iniciaram a descrição macroscópica da placa vertebral dividindo-a em duas, a placa óssea (pertencente à vertebra) e a cartilagínea (pertencente ao disco). Esta placa óssea seria nada mais que uma condensação do osso esponjoso; eles distinguem a placa óssea de um osso cortical pela presença, em indivíduos jovens, de numerosos canais similares aos do osso esponjoso. Coventry et al. confirmaram a presença do Randleiste de Schmorl ou o anel epifisário - áreas periféricas da placa óssea que inicialmente são compostas de cartilagem. Este anel gradualmente se calcifica a partir da idade de 6 anos, completa a circunferência aos 12, inicia a fusão com o corpo vertebral aos 14 e torna-se indistinguível aos 20. Já naquela época havia a controvérsia se o anel epifisário era ou não uma estrutura separada da placa cartilagínea - autores como Schmorl e Beadle sustentavam que não há evidência de crescimento endocondral no anel epifisário cartilagíneo, e sua única função seria ancorar as fibras do anel fibroso. Por outro lado, Keyes e Compere, Mau e Haas postularam que o anel epifisário é uma parte da placa cartilagínea e somente se funde ao 
corpo vertebral ao final do crescimento longitudinal. O restante da placa cartilagínea prosseguiria com sua função no disco vertebral, seus limites adjacentes ao anel ósseo $34,42,54,55$. Coventry et al. não favoreceram uma teoria ou outra (que permanece em aberto até nossos dias), mas comprovou que o anel era completo em todos os seus 88 espécimes embora menos espesso em sua porção posterior. Já a placa cartilagínea é composta de cartilagem hialina comum, com arranjo grosseiramente horizontal, e está relacionada com a síntese do tecido fibrocartilagíneo do anel fibroso ${ }^{1}$.

Estes autores ainda delinearam no primeiro de seus artigos o anel fibroso, descrevendo-o como a estrutura limitante do disco, composto por lamelas fibrosas e fibrocartilagíneas que se alternam em diferentes orientações enquanto alinhadas dentro de uma mesma lamela. 0 anel fibroso, segundo eles, é a maior e mais forte porção do disco intervertebral, mais espesso e resistente em sua porção anterior que posterior, sendo que algumas das lamelas penetram o osso da vértebra ancorando-se como fibras de Sharpey, conferindo resistência adicional. Já nesta descrição Coventry et al. enfatizaram que não há limite nítido entre o anel e o núcleo na maioria dos indivíduos adultos; isto não deveria ocorrer, portanto, como surpresa aos anatomistas dos próximos 65 anos que repetidamente descreveram esta característica como novidade ${ }^{53,56}$. Quanto ao núcleo pulposo, identificaram-no como a porção dinâmica ou ativa do disco em virtude de sua consistência semigelatinosa. Sua linha de demarcação desaparece ao longo da terceira década de vida e, embora autores anteriores tenham identificado remanescentes notocordais ao nascimento, Coventry et al. não lograram identificar nenhum; mencionaram, isso sim, que os núcleos adultos contêm fibroblastos e condrócitos em seu interior, ressaltando ainda que não há cavidade recoberta por uma membrana sinovial em seu interior, demonstrando como esta idéia persistia mesmo 100 anos depois da descrição equivocada de Luschka. De fato, ainda hoje há anatomistas que tentam aplicar o modelo de diartrose ao disco intervertebral ${ }^{1,57}$. Por fim, apontaram a presença de canais vasculares através da placa vertebral até a idade de 30 anos, confirmando pesquisas de Übermuth, e comentaram rapidamente acerca das supostas fibras nervosas encontradas na porção posterior do anel fibroso e ligamento longitudinal posterior - embora Roofe as tenha descrito e apontado a ausência de órgãos receptores especializados como indicativo de estas terminações nervosas estarem envolvidas com a 
transmissão de impulsos dolorosos, Coventry et al. não conseguiram detectar nenhuma fibra nervosa com as colorações de rotina ${ }^{33,58}$.

Assim como diversos autores antes deles, Coventry et al. perceberam que o disco sofria modificações ao longo da vida e estava longe de ser um vestígio inerte. Estes autores tentaram, pela primeira vez, distinguir seus achados entre "envelhecimento normal" e "achados degenerativos". Coventry et al. o fizeram, entretanto, de maneira completamente arbitrária. Ao listar as modificações que o disco sofre ao longo da vida, desde o primeiro ano de idade até a oitava década, Coventry et al. descreveram o desaparecimento dos canais vasculares, a progressiva perda da distinção anel-núcleo, substituição do tecido nuclear original por fibrocartilagem, o surgimento dos grupos de condrócitos no interior do disco, adensamento das fibras que compõem o anel fibroso, hialinização cartilagínea da placa vertebral, vascularização da porção posterior do anel fibroso, o aparecimento de fissuras no disco e a extrusão (em pequena quantidade) de material nuclear pela placa vertebral - todas estas alterações foram listadas pelos autores em seu segundo trabalho, tratando de alterações ditas "normais" do desenvolvimento e senescência do disco. Em outro grupo, foram listadas como "anormais" ou "patológicas", alterações como o surgimento de osteófitos, expansão e inchaço do núcleo pulposo, achatamento discal, protrusões anteriores e posteriores (com ruptura total ou parcial das fibras do anel fibroso), presença de nódulos de Schmorl (inclusões macro- ou microscópicas de material nuclear no osso esponjoso do corpo verterbal) e calcificações do núcleo pulposo ${ }^{50,51}$. Os próprios autores apontaram a maior deficiência de sua classificação e reafirmaram a falta de critérios para dividir as alterações desta maneira; por exemplo, reconhecem que a maioria (56/88) dos discos estudados apresentava nódulos de Schmorl e, portanto, alterações supostamente patológicas seriam a regra, e não a exceção na população geral. Além disso, fizeram questão de ressaltar que muitas das alterações apontadas como patológicas podem ser assintomáticas: osteófitos, expansão nuclear, protrusões anteriores e posteriores discretas e os mesmos nódulos de Schmorl (enquanto a quantidade de material extruído não fosse significativa a ponto de provocar uma diminuição da altura discal) poderiam estar entre estas últimas ${ }^{50,51}$. 
Estes pioneiros devem ser lembrados por terem sumarizado os conhecimentos da época e adicionado importantes contribuições, além de terem lançado as bases histológicas para a avaliação da degeneração discal. Ainda assim, reconheceram a dificuldade de dividir estas alterações entre envelhecimento normal e patológico; são, com razão, considerados até hoje como os mais importantes trabalhos acerca da degeneração discal.

\subsection{Adições modernas à biologia do disco intervertebral}

Embora as principais características anatômicas e histológicas dos discos intervertebrais tenham sido delineadas à época de Coventry et al., muito ainda havia por se estudar quanto ao seu desenvolvimento, composição e ultraestrutura. Com a proliferação dos modelos e métodos de estudo do disco intervertebral na segunda metade do século XX, multiplicou-se o nosso conhecimento sobre estas estruturas, acumulando-se por vezes de maneira até desordenada. Torna-se então um desafio bastante interessante organizar e compreender o que estes novos dados representam para a prática clínica.

A despeito dos diferentes métodos empregados, os estudos realizados no período pós-1945 caracterizam-se por raramente estudar isoladamente as características morfológicas do disco. Na maioria das vezes, dedicam-se a analisar algum aspecto do disco intervertebral através de determinada técnica e, simultaneamente, descrever o mesmo critério em uma população idosa, sintomática ou ainda, no caso particular dos estudos de imagem, nos mesmos individuos após um prolongado período de tempo. Sendo assim, as frentes de investigação são agrupadas abaixo conforme a área e suas conclusões, revisadas. 


\subsubsection{Hidratação do disco intervertebral e conteúdo de proteoglicanas}

Desde as primeiras décadas do século XX sabe-se que a maior parte da massa do disco é composta por água, principalmente ligada a proteoglicanas - uma das duas mais importantes classes de macromoléculas encontradas nos discos, juntamente com a família dos colágenos. Já se provou também que estas proteoglicanas (PGs) são as principais moléculas que compõem o NP, onde são responsáveis por resistir a forças de compressão, enquanto que os colágenos, concentrados no anel fibroso, proporcionam resistência a forças de rotação, translação e distração ${ }^{59,60}$.

Püschel foi o primeiro a descrever a desidratação do disco intervertebral durante o processo de envelhecimento em 1930, seguido por Eckert e Decker que correlacionaram o mesmo fato com a degeneração do disco ${ }^{61,62}$. Entretanto, foi apenas muito mais tarde que se identificou esta desidratação como uma diminuição no conteúdo de PGs, descrita inicialmente por Taylor et al. no início dos anos $1990^{61,65}$. Sabe-se que as PGs são glicoproteínas constituídas por uma proteína central e uma ou mais cadeias laterais de glicosaminoglicanas (GAGs). As PGs encontradas nos discos intervertebrais são de dois tipos: as "large aggregating" - aggrecan e versican - e as "small interstitial" - biglycan, decorin, fibromodulin e lumican, estas também chamadas de SLRPs, ou "small leucine-rich proteoglycans". São as grandes PGs agregadoras, em particular a aggrecan, responsáveis pela maior parte da capacidade do disco de reter água, devido à pressão osmótica gerada pelas numerosas cadeias laterais de $\mathrm{GAGs}^{60,63}$.

Desde a identificação pioneira de GAGs no disco intervertebral por Hallen em $1962^{64}$, diversos autores tentaram identificar quais eram as principais GAGs e como este conteúdo se modificaria com o envelhecimento - talvez esta seja a área em que mais informação tenha sido produzida acerca dos discos intervertebrais. As principais GAGs presentes nos discos intervertebrais humanos são sulfato de condroitina, sulfato de keratan, sulfato de dermatan e hialuronan. Uma das alterações consideradas "clássicas" do envelhecimento nos 
discos intervertebrais é o aumento da relação sulfato de keratan/sulfato de condroitina identificado por Lyons et al. em 1964. Ulteriormente, a via bioquímica que dá origem a estas duas moléculas foi elucidada e descobriu-se que a síntese de sulfato de condroitina exige oxigênio já na sua primeira etapa, na conversão de UDP-glicose (UDP: uracila-difosfato) para UDP-ácido glucorônico. Na ausência de oxigênio, esta conversão é desviada para UDPgalactose, que ao final resultará em sulfato de keratan. Assim, ao longo da década de 1980 elevadas proporções de sulfato de keratan foram identificadas em tecidos com vascularização deficiente - especificamente na córnea, diversos tipos de cartilagem e no disco intervertebral ${ }^{60,65,66}$. A maior quantidade de sulfato de keratan também foi percebida em condições patológicas que levam a uma diminuição na difusão de oxigênio, como no espessamento da córnea, e é nítida sua relação com a oclusão dos canais vasculares na placa vertebral durante a infância: o aumento mais pronunciado na quantidade de sulfato de keratan no disco intervertebral humano ocorre ao redor dos 10 anos de vida. A partir daí, o aumento é muito mais gradual ${ }^{65,66}$.

Além do elevado poder osmótico das grandes moléculas de PGs, sabe-se que as pequenas PGs exercem papel fundamental no remodelamento da matriz extracelular. Estas moléculas influenciam a atividade metabólica do disco ligando-se a colágenos, fatores de crescimento, receptores de superfície em fibroblastos e moléculas como fibronectina e trombospondina, afetando a síntese de fibrilas de colágeno e regulando o processo de reparo no disco intervertebral. Exatamente como isso acontece não é conhecido; os dados na literatura são esparsos e muitas vezes derivados de modelos experimentais simplificados. Aparentemente, fibromodulin e lumican estão envolvidas regulação da síntese de colágeno - sabe-se que camundongos geneticamente modificados fibromodulin-null exibem fibrilas de colágeno mais finas, além de um aumento correspondente de lumican. Já se mostrou também que a quebra das moléculas de fibromodulin induz a resposta inflamatória através da ligação com a fração C1q do complemento. De qualquer maneira, parece estabelecido que estas pequenas PGs possuem um papel ativo nas transformações que o disco intervertebral sofre ao longo da vida. Enquanto que o conteúdo absoluto de colágeno e grandes PGs diminui ao longo da vida, algumas pequenas PGs como fibromodulin e biglycan acumulam-se em diferentes setores do disco. Esta interação é uma das áreas de pesquisa em morfologia de 
discos intervertebrais mais ativas e importantes contribuições para o estudo da senescência normal do disco intervertebral ainda devem surgir ${ }^{60,67,68}$.

\subsubsection{O sistema de fibras colágenas no disco intervertebral - "perfil colágeno"}

A outra classe de macromoléculas que compõe o disco intervertebral é a dos colágenos. Juntamente com as PGs, estas macromoléculas são responsáveis por $80 \%$ do peso seco do disco intervertebral ${ }^{69}$. A descrição inicial da presença de colágenos no disco intervertebral humano data de 1954, por Naylor et al. - como a maioria dos estudos da segunda metade do século $\mathrm{XX}$, o estudo buscava não apenas descrever o perfil desta classe de proteínas através de cristalografia mas também como este padrão se modificava com 0 envelhecimento ${ }^{70}$. Uma caracterização mais detalhada deste sistema de fibras, entretanto, estava limitada pelos métodos disponíveis à época e o desconhecimento dos diferentes tipos de colágenos. Sendo assim, as alterações próprias do envelhecimento foram inicialmente descritas apenas em termos de mudança de eixo da cristalografia. Deste então, diferentes métodos morfológicos surgiram e foram gradualmente aplicados ao estudo dos colágenos do disco intervertebebral: microscopia óptica com polarização ${ }^{71}$, microscopia eletrônica ${ }^{72,73}$, cromatografia com brometo de cianogênio ${ }^{74}$ e imuno-histoquímica ${ }^{75}$ entre outros métodos menos comuns.

A despeito de dados iniciais fornecidos por cromatografia, a diferenciação dos diferentes tipos de colágeno torna-se possível a partir dos estudos de microscopia eletrônica. Todavia, a correlação dos diferentes tipos de colágeno com a histologia e arranjo espacial do disco intervertebral torna-se factível para um número razoável de espécimes apenas com o advento de técnicas imunológicas (imuno-histoquímica e/ou imuno-fluorescência) e técnicas especiais de microscopia óptica, em meados dos anos $1970^{76-79}$. Ainda assim, uma análise detalhada de um grande número de setores e espécimes através de técnicas imunológicas é problemática em virtude do tempo e custos envolvidos. Por outro lado, a alternativa mais barata, microscopia óptica com coloração pela técnica de Picro-Sirius, raramente foi utilizada 
para estudar o disco intervertebral: existem na literatura apenas estudos animais ou relatos isolados em que a mesma foi empregada ${ }^{80-83}$.

Os trabalhos pioneiros de identificação dos diferentes tipos de colágeno no disco intervertebral foram publicados por Eyre e Muir, inicialmente em porcos e depois em humanos $^{74,84}$. Estes autores, através de estudo por cromatografia com brometo de cianogênio, mencionam a presença exclusiva de colágeno tipo I no AF e do colágeno tipo II no NP. Este método, além de bem pouco prático, levou-os a esta conclusão precipitada de "presença exclusiva" em ambos os setores do disco. Foi só com os estudos imunológicos que a caracterização detalhada dos colágenos dos discos interverterbrais humanos efetivamente foi alcançada.

O primeiro estudo da distribuição dos colágenos no disco intervertebral por técnica imunológica foi o de Beard et $\mathrm{al}^{69}$. Como a maioria dos estudos imuno-histoquímicos ou por imuno-fluorescência, a intensidade da marcação foi graduada por um sistema semiqualitativo que possui uma subjetividade inerente. Além disso, estudos deste tipo frequentemente demonstram imagens em grande aumento de uma ou duas células, usualmente fibroblastos ou condrócitos, fortemente marcadas - o estudo de Beard et al. não foge a esta regra ${ }^{69}$. Embora este tipo de imagem enfatize a intensidade da coloração e produza um resultado gráfico impressionante, é de importância limitada pois impede uma análise regional para avaliação da porcentagem de células ou área marcadas. Beard et al. adicionaram à descrição pioneira de Eyre e Muir que colágeno tipo I estava ausente no NP mas também na porção profunda do AF; por outro lado, as fibras superficiais do AF eram quase que exclusivamente compostas de colágeno tipo $\mathrm{I}^{69}$. Esta marcação para colágeno tipo I foi mais forte em neonatos, diminuindo com o envelhecimento. Já colágeno tipo II era o principal componente do NP, embora pudesse ser encontrado também nas lamelas mais superficiais do AF ao contrário do afirmado por Eyre e Muir, sem apresentar variação significativa ao longo do processo de envelhecimento. Por fim, colágeno tipo III foi descrito de maneira menos frequente nas lamelas profundas do AF e NP. Apesar das generalizações, o trabalho de Beard et al. é notável não só por seu pioneirismo, mas também por produzir o 
único dado acerca do perfil colágeno em discos cervicais: em duas linhas, Beard et al. afirmaram que ao analisar os discos cervicais, torácicos e lombares de três indíviduos (um neonato, uma criança de três meses e um adulto de 40 anos) o perfil colágeno "não variou"$^{\prime \prime 9}$.

A partir deste estudo pioneiro, Roberts et al. prosseguiram na determinação do perfil colágeno, desta vez avaliando um maior número de tipos de colágeno (I, II, III, IV, VI e IX) em peças de autópsia, cirurgia e nucleotomia ${ }^{85,86}$. Nestes estudos, as indicações para cirurgia foram bastante vagas (uma delas é reportada apenas como "paraplegia"), mas Roberts et al. assumem que espécimes cirúrgicos representariam indivíduos "sintomáticos" para efeitos de comparação. Os resultados foram diferentes do que a maior parte da literatura reportava até o momento: especificamente, Roberts et al. afirmam que houve "pouca" reatividade para colágeno I, apenas nas lamelas mais externas do disco intervertebral. Colágeno tipo II estava disperso por toda a matriz, assim como os tipos III e VI. Colágeno tipo II ainda representou a quase totalidade dos colágenos na placa vertebral, contando com a completa ausência de colágeno tipo I neste setor. Por outro lado, colágenos tipos IV e IX estavam ausentes de discos humanos considerados "normais", embora colágeno tipo IV pudesse ser ocasionalmente detectado na placa vertebral. Além desta descrição, Roberts et al. optaram por enfatizar a análise dos espécimes obtidos em cirurgia. Pouca diferença em relação aos espécimes retirados de autópsia foi notada na marcação para colágeno tipo II; um aumento na expressão de colágeno tipo I foi percebido, sem, entretanto, delinearem região discal ou magnitude. As maiores diferenças foram vistas na expressão de colágeno tipo III e VI colágeno tipo III estava expresso em maior quantidade, particularmente ao redor de grupos de condrócitos, e colágeno tipo $\mathrm{VI}$, em menor quantidade. Por fim, uma pequena quantidade de colágeno tipo IX foi detectada em discos removidos durante cirurgia. O trabalho de Roberts et al. é notável por analisar outros tipos de colágeno menos frequentemente encontrados no disco, procurar uma discriminação regional em sua análise e buscar comparar grupos teoricamente sintomático e controle. Contudo, o trabalho sofre das mesmas deficiências que se tornarão recorrentes neste tipo de estudo, como subjetividade na avaliação da expressão imuno-histoquímica, descrição regional vaga e grande variação etária dentro dos grupos (de 21 a 85 anos no grupo "controle") - como relatado 
anteriormente por Coventry et al., o aspecto histológico de discos lombares de indivíduos na terceira e nona décadas de vida varia imensamente. Assim, não há como classificá-los dentro de um mesmo grupo para efeitos de controle, muito menos considerar os achados dentro de tal grupo como homogêneos ${ }^{1,50,51,86}$.

A despeito dos muitas análises de expressão de colágeno em modelos animais e de cultura de células encontrados na literatura, o número de trabalhos que envolvem discos com sua estrutura intacta e realizam uma análise regional em humanos é diminuto ${ }^{53,83,87}$. Neste sentido, destacam-se os trabalhos do grupo de Andreas Nerlich, em Munique, Alemanha. Este grupo publicou três trabalhos entre 1997 e 2002 tratando da diversos aspectos estruturais de discos lombares humanos, tendo recebido diversos prêmios por esta análise ${ }^{53,56,88}$. Até hoje, estes trabalhos são reconhecidos como as mais importantes contribuições para o estudo do perfil colágeno em discos lombares. Estes autores partiram de um grupo presumivelmente assintomático de 47 cadáveres de diversas idades (neonatos até 86 anos), de onde obtiveram 229 discos lombares para análise histológica. Deste total, selecionaram 45 discos L3L4 para análise imuno-histoquímica, além de mais 20 discos lombares (o segmento nunca foi mencionado) com "degeneração signifcativa". Em seus 2 estudos iniciais, Nerlich et al. reiteraram as impressões de Coventry et al. ao descrever progressivas alterações histológicas na medida que analisa cadáveres mais idosos: fendas iniciais em discos de adolescentes (13-16 anos), tornando-se mais comuns até estarem presentes em todos os cadáveres de adultos jovens (16-25 anos); grupos de condrócitos ("clusters") progressivamente maiores a medida que o grau de degeneração macroscópica (escala de Thompson) aumenta, especialmente ao lado de grandes fendas; aumento e adensamento do componente fibroso; "modificações granulares", alterações da matriz extracelular do NP conforme descritas por Coventry et al.; proliferação vascular e a perda da distinção anel-nuclear como um dos eventos finais da degeneração ("burnt-out") 1,56,88.

Nerlich et al. procederam então uma análise semi-quantitativa da expressão dos diferentes tipos de colágeno através de imuno-histoquímica ${ }^{56}$. Iniciando com os indivíduos mais jovens, verificaram que colágeno I é expresso principalmente na região superficial do AF mas 
também em sua região profunda; não foi detectada expressão no NP. A expressão de colágeno tipo II segue um gradiente oposto: sem expressão no AF superficial, é mais frequentemente encontrado no NP e na placa vertebral. Colágeno III estava discretamente expresso no $\mathrm{AF}$, enquanto colágeno $\mathrm{V}$ e VI eram visualizados tanto no AF como NP. Colágeno VI, especificamente, era mais frequente ao redor de condrócitos no NP e na placa vertebral, enquanto que no AF estava associado com a matriz intersticial. Colágeno IX foi encontrado em associação com colágeno II, respeitando sua distribuição com uma marcação pericelular discretamente mais forte.

Ao analisar cadáveres de indivíduos mais idosos, algumas mudanças na expressão dos diferentes colágenos ficaram evidentes. Colágeno I passa a ser expresso no NP em indivíduos com discos muito degenerados; mesmo no AF, a expressão aumenta. Colágeno II aumenta discretamente com a idade, mas nos discos Thompson $V$ a expressão é diminuída, padrão também seguido por colágeno III e VI. Colágeno V passa a ser detectado na placa vertebral de discos degenerados. Por fim, quando a distinção AF-NP é perdida, a expressão de colágenos II e IX diminui severamente, enquanto que a maior parte do disco é positiva para colágenos I, III, V e VI. Bastante peculiar foi a análise de Nerlich et al. para a presença de dois colágenos que, consideram estes autores, não fariam parte do disco intervertebral "normal"colágenos IV e X. Embora ausentes de discos de crianças, a expressão de colágeno IV aumenta no NP até atingir um pico em adultos jovens, enquanto que colágeno $X$ foi visto apenas após os 47 anos, com um aumento "algo linear" ("somewhat linear") a partir de então. Como uma última análise, Nerlich et al. introduziram a $\mathrm{N}$-carboximetil-lisina ( $N$ (carboxymethyl)-lysine, ou $\mathrm{CML}$ ) como critério de degeneração do disco intervertebral. $\mathrm{A}$ CML é então formada como uma modificação pós-translacional de proteínas em ambiente com grande conteúdo de radicais livres de oxigênio ${ }^{52}$. A expressão de CML foi detectada em espécimes a partir dos 13 anos de idade, aumentando de maneira linear a partir desta idade porém mantendo-se ausente de discos sem alterações histológicas significativas. Muitos destes critérios histológicos foram depois incorporados pelo grupo em um sistema de gradação da degeneração discal, embora o perfil colágeno e a expressão de CML tenham sido deixados de lado ${ }^{53}$. 
A análise que estes autores fazem dos extensos dados oriundos de seu trabalho é muito interessante. Eles propuseram considerar os colágenos IV (em adultos jovens) e X (em idosos) como marcadores fenotípicos de uma modificação celular do disco intervertebral que ulteriormente levaria à destruição da estrutura do disco. O colágeno $X$, em particular, é enfatizado como sendo produzido apenas por condrócitos hipertróficos e portanto um dos sinais avançados de degeneração. Os resultados destes três estudos são muito importantes e colocam estes trabalhos de Nerlich et al. no mesmo patamar de importância que a trilogia de Conventry et al. ${ }^{1,56}$. Entretanto, e apesar de seu pioneirismo na descrição do perfil colágeno, Nerlich et al. deixa evidente algumas discrepâncias com relação aos trabalhos mais antigos $^{56}$. A expressão de colágeno I segundo Nerlich et al. e Roberts et al. é muito menor que se esperaria a partir dos trabalhos de análise bioquímica. Estes autores então supõem um mecanismo de mascaramento em virtude do arranjo compacto de fibras paralelas ${ }^{56,91}$. Na verdade, esta teoria é puramente especulativa, já que múltiplos fatores, desde falta de afinidade pelo anticorpo até mascaramento em virtude de fixação podem explicar este fenômeno. Talvez a crítica mais importante é que, apesar de os autores tentarem alguma quantificação, a análise das variações do perfil colágeno ainda é completamente subjetiva um sistema com gradação de " 0 " a "4+" não é apropriado para uma análise de variação temporal. Os resultados de Nerlich et al., possivelmente em virtude desta classificação imperfeita, são descritos em termos de uma impressionante homogeneidade por faixa etária ${ }^{56}$.

A despeito destas questões em aberto, não há na literatura mais análises do perfil colágeno em discos humanos, certamente devido não só à dificuldade em se obter espécimes cadavéricos padronizados em relação a idade mas também à complexidade da condução de estudos imuno-histoquímicos para diversas proteínas em material tão grande como o disco. 


\subsubsection{Desenvolvimento e degeneração discal}

A biologia do disco intervertebral é alvo de grande atenção na comunidade científica hoje três vezes mais artigos foram publicados em 2007 acerca deste assunto que em $1997^{89}$. A fronteira entre o envelhecimento discal considerado normal e alterações consideradas patológicas é absolutamente indistinta e reconhecida como tal desde o início dos estudos morfológicos do disco intervertebral, por exemplo, por Coventry et al. ${ }^{1,50,51}$. Mais uma vez, foram estes os primeiros autores a tentarem uma divisão - além do critério de "gravidade" das alterações morfológicas, puderam, através de seu estudo, introduzir o conceito de "frequência" das alterações. Assim, alterações menos graves e mais comuns (pequenas fissuras no AF, por exemplo) seriam parte do envelhecimento normal, enquanto que modificações "avançadas" e infrequentes (como herniações anteriores ou posteriores) seriam patológicas. Os próprios autores apontaram como esta tentativa de utilização da frequência poderia ser inadequada - 56 dos 88 discos estudados possuíam nódulos de Schmorl, considerados por Coventry et al. como uma alteração patológica, e assim lamentaram a dificuldade para chegar a uma distinção satisfatória ${ }^{50}$.

A partir da determinação de diversas alterações histológicas por Coventry et al. bem como a sequência em que ocorrem, em 1954 outro critério foi introduzido por Harris e MacNab para classificar as alterações morfológicas - a cronologia $^{90}$. Em sua revisão, os autores sugerem que a detecção em idades precoces das alterações esperadas para mais tarde na vida, baseadas largamente na descrição de Coventry et al., caracterizariam alterações patológicas $^{1,90}$. Estas duas maneiras de distinguir o envelhecimento normal da doença degenerativa discal permanecem em uso até hoje ${ }^{91}$. Em particular, autores que não levaram em conta estudos de imagem, como Adams e Roughley, prosseguem utilizando uma definição baseada em gravidade e frequência ${ }^{92}$. Estes autores utilizaram uma definição de degeneração discal como "falência estrutural devido a um processo de remodelamento discal mediado por células", e realizam a distinção entre envelhecimento e degeneração patológica pelo conceito abstrato de "falência estrutural". Além da dificuldade de conceituar "falência estrutural", possivelmente tendo que recorrer a características clínicas, é fácil 
perceber que alterações precoces/mínimas (como pequenas fissuras ou grupos de condrócitos no AF) são parte do envelhecimento normal, enquanto que alterações extremas/tardias (como herniações francas ou o completo achatamento do disco) seriam patológicas e parte da DDD. Entretanto, resta toda uma faixa de alterações intermediárias cuja classificação não é clara, além de ser difícil conciliar o conceito de alterações patológicas, por vezes bastante numerosas, em indivíduos absolutamente assintomáticos. Neste sentido, os estudos de imagem, em particular a RM, tiveram papel crucial para se chegar a uma definição moderna de degeneração discal ${ }^{92,93}$.

Frente ao desafio de uniformizar os termos empregados para o estudo das alterações morfológicas do disco intervertebral de etiologia não-traumática, Fardon e Milette propuseram um consenso em 2001 através dos esforços de uma força-tarefa composta por membros de sociedades profissionais americanas de cirurgiões de coluna e radiologistas ${ }^{93}$. Reconhecendo a frequente falta de correlação das alterações morfológicas com sintomas, Fardon e Milette iniciaram sua revisão ao afirmar que qualquer esforço para tentar diferenciar alterações morfológicas decorrentes do envelhecimento normal de alterações ditas patológicas é, na verdade, inútil. Sendo assim, estabeleceram como disco intervertebral "normal" o disco jovem sem quaisquer alterações morfológicas ainda que, dentro de determinado contexto, estas possam ser consideradas próprias da idade. Assim, sabe-se que a ocorrência de tais discos é possível apenas em idades muito precoces. Consequentemente, Fardon e Milette agruparam sob o termo "degeneração discal" o conjunto de todas estas alterações morfológicas em nível celular, mesmo que possam ser consideradas "normal para a idade" ou assintomáticas, esquivando-se assim de realizar a distinção entre patológico e normal. Por fim, reservaram o termo "doença degenerativa discal" (DDD) apenas para a síndrome clínica caracterizada por manifestações dolorosas atribuídas à degeneração discal. As definições de degeneração discal e DDD são muito apropriadas, uma vez que os autores enfatizaram que a correlação é difícil de ser feita e o termo DDD não deve ser usado na ausência de sintomas. Estas definições serão utilizadas ao longo deste trabalho, e "degeneração" será empregada também para descrever as alterações verificadas nos discos de indivíduos presumivelmente assintomáticos ${ }^{93}$. 
O evento dominante ao longo do desenvolvimento discal no período pós-natal é a diminuição e eventual término do suprimento vascular em uma idade muito precoce, gerando um ambiente avascular. Este fato é conhecido de longa data e foi inicialmente descrito por Übermuth e Bohmig (1930) ${ }^{58,94}$. Ambos os autores localizam o fechamento dos pequenos vasos que atravessam a placa vertebral ao redor dos 8-9 anos de idade; Coventry et al., por outro lado, afirmam ter detectado estes vasos em indivíduos mais velhos de até 33 $\operatorname{anos}^{50}$. A maioria dos autores hoje concorda que estes vasos são obliterados ainda na primeira década de vida e o microambiente discal pobre em oxigênio é o evento desencadeador da sequência de alterações degenerativas no disco intervertebral. Ainda assim, o disco permanece metabolicamente ativo, suportado por difusão através da placa vertebral ou a partir dos vasos que normalmente ocorrem na periferia do anel fibroso ${ }^{98}$.

Imagina-se que a transformação do microambiente discal em uma área de metabolismo predominantemente anaeróbio é o evento desencadeante das transformações morfológicas descritas nas seções acima ${ }^{95}$. Para que haja as extensas mudanças no perfil de PGs e colágenos já revisadas, a matriz extracelular necessita ser extensamente remodelada, o que decorre de alterações no balanço entre síntese e degradação de cada componente individual desta matriz. A degradação destes componentes protéicos da matriz discal ocorre pela ação de enzimas agrupadas genericamente sob o termo "proteases". As principais proteinases envolvidas neste processo são as matrix metalloproteinases ou MMPs. Estas enzimas, inicialmente detectadas em outros tecidos, sabidamente estão envolvidas na degeneração de cartilagem de outras articulações no corpo humano. As MMPs são subdivididas ainda de acordo com seus principais alvos: assim, há MMPs que recebem a denominação "colagenases", como a MMP-1, MMP-8, MMP-13 e MMP-18, por atuarem sobre os colágenos fibrilares intactos (I, II e III); há as "gelatinases", como MMP-2 e MMP-9, que podem clivar tanto móleculas da membrana basal bem como moléculas desnaturadas de colágeno; e as "stromelysins", como MMP-3, MMP-10 e MMP-11, que degradam colágeno e outras proteínas como fibronectina e proteoglicanas, por exemplo. Estas moléculas são secretadas inicialmente como pró-enzimas e, uma vez ativadas, dependem da ação de 
enzimas chamadas "tissue-inhibitors-of-matrix-metalloproteinases" (TIMPs) para serem inativadas. Inicialmente descritas no disco intervertebral herniado por Kang et al., uma correlação entre maior expressão de MMPs e idade (particularmente MMP-1, -2, -3 e -9) foi demonstrada por Weiler et al. ${ }^{96-99}$. De maneira até mais importante, Weiler et al. conseguiram ainda correlacionar maior expressão de MMP-1 e -2 no AF e -1, -2 e -3 no NP com maiores achados histológicos de degeneração ${ }^{100-103}$. Por outro lado, Roberts et al. também detectaram maior expressão de TIMP-1 em espécimes removidos de cirurgia, inferindo isto como evidência de um processo ativo de degredação e remodelamento ${ }^{102}$. Baseados largamente nos estudos de Roberts et al. e Weiler et al., pensa-se hoje que as MMPs estão implicadas no remodelamento da matriz extracelular do disco durante o processo degenerativo ${ }^{96,102}$. Todavia, estes estudos possuem diversos pontos em aberto e falhas de metodologia, como a falta de explicação para expressão significativa de MMP-8 no disco (expressa apenas por neutrófilos, normalmente ausentes na degeneração sem herniação), ausência de distinção regional (NP versus AF) por Roberts et al. e uso de espécimes não-padronizados, inclusive combinando amostras obtidas de cirurgia (sintomáticos) e autópsia (presumivelmente assintomáticos) ${ }^{102}$. A associação de MMPs e TIMPs com o processo degenerativo também foi demonstrada através de modelos animais e experimentos in vitro, embora a distinção entre idade e degeneração nas correlações com a expressão de MMPs e TIMPs nos discos intervertebrais ainda esteja por ser estudada. Um estudo com discos de idosos, porém divididos entre grupos com degeneração incipiente e avançada potencialmente distinguiria se a expressão destras moléculas é apenas um marcador para envelhecimento ou de fato relacionada com o processo degenerativo.

Uma série de outras moléculas com presumível função modulatória do processo degenerativo discal foram extensamente estudadas. Tumor necrosis factor-alpha (TNF- $\alpha$ ) é um dos mais potentes mediadores pró-inflamatórios conhecidos e também modula a ação das moléculas da família das MMPs. Detectado em casos de herniação discal franca, acredita-se a partir de estudos animais que seja um dos mediadores responsáveis pela dor irradiada típica da radiculopatia ${ }^{104}$. Uma correlação positiva entre expressão de TNF- $\alpha$ no AF e idade ou degeneração foi demonstrada por Weiler et al. ${ }^{101}$. Apesar de outros grupos terem 
apontado resultados conflitantes, isto foi geralmente confirmado no AF pela ulterior associação com idade ou grau histológico de degeneração não só da própria molécula de TNF- $\alpha$ como também de seus 2 receptores e enzima conversora. Não há como fazer a distinção se o aumento da expressão de TNF- $\alpha$ é causa ou consequência do processo degenerativo, ou ainda compreender plenamente as vias pelas quais o TNF- $\alpha$ influi no remodelamento da matriz, mas novamente torna-se um candidato a mediador importante no processo degenerativo ${ }^{101,105,106}$.

Sugeriu-se ainda, através de estudos in vitro, que moléculas como TGF- $\beta$ (Transforming Growth Factor-beta), IGF-1 (Insulin-like Growth Factor-1), interleucina-1 (IL-1) e seu receptor IL-1R, IL-6/IL-6R, IL-8, INF- $\gamma$ (Interferon-gama) e prostaglandina $\mathrm{E}_{2}$ estariam super-expressas em discos degenerados, envelhecidos ou removidos de pacientes com dor discogênica ${ }^{103,106,107}$. TGF- $\beta$ em particular foi também detectado em um pequeno estudo por Nerlich et al. em uma frequência aumentada em indivíduos mais idosos, especialmente em associação com a expressão de fibronectina; trata-se de um pequeno estudo, qualitativo e sem análise estatística mais aprofundada ${ }^{108}$. IL-1 e seu receptor IL-1R foram detectados em quantidades aumentadas por Le Maitre et al. no AF interno e NP de discos degenerados estes autores agruparam discos obtidos de autópsia e cirurgia em grupos não-degenerado, degenerado e herniado ${ }^{109}$.

Dois outros processos frequentemente associados com a degeneração discal são a angiogênese e proliferação de teminais nervosos no disco. A angiogênese em particular é mais comumente relacionada com a herniação discal franca, com extensa documentação de sua ocorrência, usualmente considerada parte do processo inflamatório e muito mais uma consequência do que uma causa da herniação ${ }^{110}$. Ultimamente, alguns estudos associaram a presença de vascular endothelial growth factor (VEGF) com degeneração discal apenas, e não herniação ${ }^{110,111}$. Sabe-se que a produção de VEGF é estimulada por duas citocinas envolvidas na degeneração discal, IL-1 e TNF- $\alpha$. Lee et al. apontam que a expressão de VEGF 
pode até ser maior em espécimes unicamente degenerados do que em discos francamente herniados, fato suportado por alguns estudos animais ${ }^{110-112}$.

Assim como no caso de pequenos vasos, sabe-se que terminais nervosos estão presentes nas porções periféricas do AF desde pelo menos o início do século XX - Testut descreveu a presença destas fibras nervosas em $1905^{27}$. Nas décadas seguintes, a inervação dos ligamentos longitudinais e AF foi objeto específico de investigações por diversos anatomistas como Leriche, Roofe, Jung e Brunschwig $27,28,33,34,113$. Algumas destas fibras foram traçadas até o chamado ramo recorrente lombar ou sinuvertebral (que hoje consta da Terminologia Anatômica como ramo meníngeo), particularmente aquelas na região posterior do AF e ligamento longitudinal posterior (LLP) ${ }^{31}$. Os ramos da região anterior do disco intervertebral e do ligamento longitudinal anterior (LLA) provêm, no segmento lombar, do tronco simpático e de ramos comunicantes em cada nível ${ }^{114}$. Em sua maior parte, foram descritas como fibras finas e amielínicas; considerando-se o fato de até os anos 1990 poucos órgãos receptores terem sido descritos no interior dos discos, imaginava-se já em 1940 que estes nervos possuiriam função nociceptiva ${ }^{33}$. Avanços na determinação da natureza dos órgãos receptores no disco intervertebral reveleram que os mesmos estão situados no LLA, LLP e periferia do AF. Estes seriam ainda predominantemente mecanorreceptores, com pequena função nociceptiva segundo Roberts et al., embora tal caracterização tenha sido contestada e ultimamente impossível de ser verificada completamente ${ }^{100,115}$.

Nos anos 1980, com a proliferação dos métodos de detecção imunológica, o interesse nas fibras nervosas do disco e estruturas adjacentes foi reavivado. Tanto em modelos animais como em espécimes humanas, uma série de autores descreveu a presença de fibras nervosas através da detecção de neuropeptídeos, como substância P (SP), calcitonin generelated protein (CGRP) e vasoactive intestinal peptide (VIP) ${ }^{116-120}$. Neste contexto, os trabalhos de Grönblad e Weinstein foram muito importantes para introduzir a questão do comportamento deste terminais nervosos na degeneração discal ${ }^{116,119}$. Utilizando técnicas imuno-histoquímicas, estes autores sugeriram que haveria o crescimento dos terminais nervosos sabidamente presentes na periferia do AF para suas regiões mais profundas e 
inclusive o NP. Este tema foi bastante aprofundado por Freemont et al., em estudo de grande repercussão publicado no Lancet $^{121,122}$. Estes autores compararam discos obtidos de cirurgias para artrodese lombar com espécimes de autópsias não-selecionadas através de técnicas imuno-histoquímicas para um marcador neuronal geral (PGP 9.5), um marcador de axonogênese (GAP43) e um neurotransmissor com função nociceptiva e autonômica (SP). Apesar de alguma marcação para PGP 9.5 ter sido detectada em todos os discos na periferia, Freemont et al. reportam a existência de marcação para GAP43 e SP apenas nos discos de indivíduos sintomáticos e particularmente naqueles considerados como os discos responsáveis por lombalgia através de discografia. Além disso, houve correlação importante com os outros marcadores nos indivíduos sintomáticos, com 76 e $28 \%$ das fibras positivas para PGP 9.5 também marcadas para substância P e GAP43 respectivamente ${ }^{122}$.

É interessante que Freemont et al. não correlacionaram imediatamente todos estas fibras nervosas com nocicepção. Pelo contrário, na discussão de seu artigo enfatizaram que a maioria das fibras positivas para PGP 9.5 e SP possuiriam função vasoregulatória e sempre acompanhavam vasos neo-formados no interior do disco. Segundo estes mesmos autores, as fibras positivas para GAP43 seriam as envolvidas com remodelamento discal e nocicepção aberrante. Alguns problemas comuns a vários dos trabalhos citados nesta seção também afetaram esta análise. Especificamente, a idade de nenhum espécimes não foi comentada e a histologia dos espécimes obtidos de autópsia é descrita como "normal". As únicas características histológicas citadas destes espécimes "normais" seriam clusters de até 3 condrócitos e ausência de fibrose, o que é sabido de longa data como sendo absolutamente improvável desde a mais precoce infância ${ }^{1}$. Ainda assim, as fibras teoricamente nociceptivas estenderam-se até a porção interna apenas em $41 \%$ dos casos presumidos sintomáticos ${ }^{122}$.

O grupo de Freemont et al. prosseguiu nesta linha de investigação com diversos trabalhos nos anos seguintes, implicando os fatores de crescimento Nerve Growth Factor (NGF) e Brain-derived Growth Factor (BDNF) no processo de invasão neural aberrante do disco. Segundo os mesmos autores, BDNF seria mais importante para nocicepção, uma vez que NGF foi detectado em altos níveis também em discos não degenerados. NGF por sua vez 
estaria associado com fibras nervosas de função autonômica associadas com regulação osmótica das células do disco intervertebral ${ }^{122-124}$. A produção destes fatores neurotróficos também se demonstrou responsiva a IL-1 e TNF- $\alpha$, duas citocinas implicadas no processo degenerativo ${ }^{123}$. Mais uma vez, estes novos trabalhos basearam-se em comparações com espécimes "controle" reportados com histologia "normal", sem idade definida, o que prejudica a comparação com os espécimes cirúrgicos ou "sintomáticos". Pior ainda, em pelo menos uma oportunidade o espécime controle foi removido de nível adjacente no mesmo indivíduo sintomático, poucos dias após discografia ${ }^{121}$. Outros grupos também suportaram o papel do BDNF na degeneração discal, implicando uma maior expressão deste fator de crescimento na degeneração discal, mas em nenhum estudo estes achados foram positivos na região interna do $\mathrm{AF}$ em mais de $40 \%$ dos indivíduos sintomáticos, e menos ainda para o $N P^{123,125}$.

Sem dúvida alguma, inúmeros mecanismos foram implicados durante os últimos 65 anos no processo de degeneração discal e uma revisão completa da literatura torna-se absolutamente impossível ${ }^{92,93}$. Nenhum destes mecanismos explica de maneira inequívoca a degeneração discal por completo, o que é refletido em todos as teorias atuais que enfatizam a caráter multifatorial deste processo. Torna-se evidente da mesma maneira que ainda há muito espaço para pesquisa não apenas dos indivíduos sintomáticos, mas também dos discos oriundos de indivíduos assintomáticos. A partir da revisão da literatura, percebe-se que a seleção e descrição destes espécimes não recebe o mesmo cuidado que aqueles de populações sintomáticas, presumivelmente por se tratarem dos espécimes "controle" e, portanto, menos interessantes. Até hoje, os autores que exibiram o maior cuidado na seleção e interpretação de espécimes ditos "controle" foram Coventry et al.; esta população merece uma análise mais detalhada empregando métodos modernos ${ }^{1,50,51}$. 


\subsubsection{Fisiopatologia da doença degenerativa discal}

Pelas definições de Fardon e Milette adotadas nesta tese, a fisiopatologia da doença degenerativa discal trata da origem da síndrome clínica e não de seus aspectos morfológicos puros. Portanto, analisar-se-á a origem da sintomatologia, ou seja, cervical ou lombalgia sem irradiação, partindo das considerações acerca de dor localizada da seção 1.2 desta tese. Como em todos os aspectos tratados nesta introdução, há maior literatura acerca da região lombar. $\mathrm{O}$ assunto permanece extremamente confuso e diversas teorias acerca da gênese da dor localizada à região da coluna vertebral podem ser encontradas. Na ausência de herniação discal ou déficit motor, Manchikanti et al. estimam que em $85 \%$ dos casos de lombalgia os dados de história, exame físico e imagem são incapazes de apontar a causa definitiva da lombalgia ${ }^{126}$. O único ponto em comum entre a maioria dos estudos na literatura é o reconhecimento deste caráter multifatorial e das influências que modulam a percepção dolorosa - fatores psicológicos, modulação central, plasticidade neuronal e abuso de analgésicos são alguns dos fatores mais citados, entre muitos outros ${ }^{127,128}$.

Como revisado no item 1.2, diversas estruturas podem estar envolvidas na origem da cervical ou lombalgia: Bogduk et al. revisaram fatores e estruturas vertebrais e paravertebrais que podem causar a dor localizada: espasmo muscular, pontos-gatilho, impactação de lâminas, espondilólise, ligamentos diversos e suas lesões (interespinhoso, iliolombar, entre outros), o disco intervertebral e as facetas articulares, entre outras. Há muito pouca evidência de qualidade na literatura para suportar estes dados; além disso, parte desta investigação é realizada utilizando-se de métodos de bloqueio anestésico ou invasivos, como discografia, por sua vez também controversos e com evidência limitada na literatura ${ }^{114,126,129,129}$.

Teorias sobre como o disco intervertebral pode estar envolvido na gênese da dor localizada provavelmente existem desde os primeiros estudos anatômicos. Todavia, mais do que simplesmente relacionar a dor com alterações degenerativas, mecanismos fisiopatológicos 
necessitam ser postulados. Uma das teorias mais aceitas na questão da dor localizada envolve o conceito de "segmento móvel" (motion segment) criado por Schmorl e Junghanns em $1968^{103,130}$. Estes autores consideravam o conjunto de dois corpos vertebrais adjacentes e o disco entre eles como a menor unidade funcional da coluna espinhal. Kirkaldy-Willis et al. partiram deste modelo no final dos anos 1970 para criar seu conceito de "complexo de três articulações" (three-joint complex), em que uma perfeita interação entre as duas articulações dos processos articulares (zigoapofisárias) e a sínfise intervertebral seria necessária para uma a coluna funcionar de maneira fisiológica ${ }^{131}$. Assim, alterações degenerativas do disco intervertebral afetariam as facetas articulares, e vice-versa. KirkaldyWillis utilizou o conceito de three-joint complex para explicar como degeneração discal causaria inicialmente hipertrofia facetária e ultimamente estenose central ou do recesso lateral. A partir daí, o conceito de three-joint complex foi logo adaptado para explicar também a dor localizada, através da diminuição de altura do disco intervertebral, alteração de suas propriedade mecânicas e subsequente aumento da carga sobre as facetas $\operatorname{articulares}^{103,131,132}$. A cápsula da articulação dos processos articulares é inervada em profusão por fibras $A \delta$ e $C$, fato conhecido na época de Kirkaldy-Willis uma vez que Cloward brevemente menciona a sensibilidade das facetas em seu trabalho de $1952^{133}$. Embora os nociceptores desta articulação normalmente possuam elevados limiares de estímulo mecânico, uma situação combinada de aumento de carga e sensibilização destes receptores por mediadores químicos, por exemplo, durante o processo inflamatório, levando à redução de seus limiares poderia provocar dor localizada ${ }^{103,134,135}$.

Dados abundantes suportam a teoria de "complexo de três articulações" para gênese da dor localizada. Há estudos de imagem na literatura provando que degeneração discal geralmente precede a osteoartrose das articulações facetárias, demonstrando assim o mecanismo fisiopatológico ${ }^{136,137}$. Um dos defeitos mais frequentemente apontados no modelo de Kirkaldy-Willis é que este não leva em conta a ação de estabilização de ligamentos e músculos paraespinhais. Embora os próprios criadores desta teoria reconheçam o defeito, modelos biomecânicos apontam que a adição da ação muscular sobre o modelo de Kirkaldy-Willis levaria a uma diminuição da pressão intradiscal e das forças sobre o corpo vertebral, resultando, por outro lado, em maior sobrecarga das 
articulações facetárias - ou seja, o modelo na verdade ainda estaria subestimando o papel das articulações facetárias na geração da dor ${ }^{103,128,138}$. Embora amplamente aceita, esta teoria por si só não explica a totalidade dos casos de dor localizada, seja pela elevada frequência de indivíduos asintomáticos com extensa degeneração facetária como também pela situação inversa, bastante frequente, de indivíduos sintomáticos sem alterações facetárias $^{139-141}$.

Há ainda aqueles autores que defendem que o disco seja o próprio gerador da dor - a este conceito é dado o nome de dor discogênica, e muito cuidado é necessário ao se analisar a literatura acerca deste termo. Para que o disco pudesse ser considerado intrinsecamente doloroso, havia a necessidade de se demonstrar de maneira inequívoca sua inervação como visto acima, este conceito somente foi maturado nos anos $1940^{33,34,114,129}$. Embora a origem da teoria discogênica seja difícil de precisar, sabe-se que a primeira discografia foi realizada por Schmorl em 1929 e a primeira série clínica surgiu em 1948, com Lindblom $^{142,143}$. Como se verá adiante, a discografia está intimamente ligada ao desenvolvimento do próprio conceito de dor discogênica; ainda assim, a maioria dos trabalhos ditos "pioneiros" dos anos 1940 e 1950 não se refere ao conceito moderno da dor discogênica, e sim ao mecanismo de geração de dor irradiada através do extravasamento de substâncias irritantes no espaço periradicular provocado pela ruptura do disco em oposição à compressão direta. Um exemplo é o trabalho de Raney et al. de 1949, frequentemente citado como um dos primeiros trabalhos a suportar a idéia de dor discogênica. Raney et al. especificamente alegam que, por ser uma estrutura normalmente desprovida de inervação, "a degeneração discal por si só não pode causar sintomas" e sim deve sensibilizar, quando de sua ruptura, estruturas inervadas adjacentes, provocando cefaléia cervicogênica como uma forma de dor irradiada ${ }^{144}$.

Ironicamente, talvez a primeira obra que trata do disco sendo intrinsecamente doloroso e atribuindo à sua própria inervação o papel de carrear o estímulo nociceptivo se refere aos discos da região cervical. Ao relatar a sua experiência clínica na realização de discografias no segmento cervical, Cloward descreveu uma série de dores localizadas à região da coluna 
vertebral e revisou as vias nervosas pelas quais o estímulo nociceptivo seria transmitido conforme descrito pelos anatomistas de sua época ${ }^{145}$. Cloward enfatizou que o disco é o próprio gerador da dor no contexto da degeneração discal, daí seu pioneirismo, afirmando ainda na mesma obra que aplicava a sua técnica cirúrgica, discectomia com artrodese interssomática, em discos do segmento lombar com resultados semelhantes, inferindo-se a partir daí que reconhecia o mesmo mecanismo fisiopatológico no segmento lombar pelo menos desde $1943^{133,146}$. Estes trabalhos de Cloward, por serem focados principalmente em um método diagnóstico e uma técnica cirúrgica, frequentemente passam despercebidos. $\mathrm{Na}$ maioria da literatura revisada, a descrição clínica inicial de dor discogênica é creditada a Crock em 1970 147,148. A despeito de mais de 40 anos de reconhecimento clínico, uma descrição clínica definitiva do termo dor discogênica ainda não é encontrada na literatura ${ }^{147}$. Sumarizando revisões recentes, em termos clínicos a dor discogênica pode ser definida como dor referida à região vertebral, sem irradiação de padrão típico de dermátomo que sugira radiculopatia, exclusão de outras causas orgânicas (tumores, infecção), atribuição à degeneração discal e comprovada por discografia ${ }^{126,147,149,150}$. A necessidade de comprovação por discografia para o diagnóstico inequívoco é cercada de controvérsias, como a suposta elevada ocorrência de falsos-positivos, mas ultimamente a mesma tem sido reafirmada como procedimento diagnóstico de grande valor quando a resposta é positiva de acordo com todos os critérios da International Association for the Study of Pain (IASP): discografia avaliada por tomografia computadorizada (CT) com achados degenerativos incluindo ruptura anelar, injeção de contraste em até 50 psi provocando dor típica em um determinado disco e injeção de 2 discos adjacentes sem provocação da dor típica (controles negativos) ${ }^{147,151,151-153}$.

Apesar da controvérsia gerada ao redor do emprego da discografia para confirmar a presença de dor discogênica, é geralmente aceito que esta e a dor facetária são dois dos mais importantes mecanismos pelos quais a alteração estrutural do disco pode gerar dor ${ }^{129}$. As lacunas na fisiopatologia proposta são evidentes e passam pela ocorrência destas mesmas alterações degenerativas em indivíduos assintomáticos, que são o objeto de estudo desta tese. 


\subsubsection{Genética e degeneração discal}

Apesar de múltiplos estudos, até hoje a associação entre alterações degenerativas no disco intervertebral e traços genéticos é frustra na melhor das hipóteses. Um famoso estudo de uma coorte de gêmeos dinamarqueses demonstrou alguma associação genética para a ocorrência de lombalgia; exatamente como isso acontece é incerto ${ }^{154}$. Isto decorre, dentre outras causas, de nosso desconhecimento acerca do processo fisiopatológico: os estudos genéticos mais eficientes são os de associação fenótipo - gene-candidato. Este método depende de uma previsão acertada sobre quais seriam os possíveis genes-candidatos, o que, por sua vez, depende de um profundo cohecimento do processo degenerativo. Estudos de associação fenótipo - gene-candidato também são idealmente utilizados para doenças causadas por um único gene com padrão mendeliano de herança; em condições poligênicas e com importantes influências do meio, como a degeneração discal, o poder estatístico destes estudos é muito reduzido. A abordagem alternativa, estudos genômicos de associação, não faz suposições sobre os possíveis genes envolvidos porém é muito ampla e frequentemente aponta para genes sobre os quais não se sabe a localização tampouco a função. A título de exemplo deste tipo de estudo, recentemente Gruber et al. estudaram alterações de expressão gênica em culturas de células de AF de discos degenerados (Thompson IV e V) e não-degenerados (Thompson I, II e III) ${ }^{155}$. Estes autores encontraram nada menos que 424 genes com expressão distinta entre os dois grupos, seja sub- ou superexpressão, muitos deles com função ou importância desconhecida para o processo degenerativo $^{155}$. Estudos de associação genômica são ainda mais complicados em virtude das variações da doença degenerativa discal de acordo com a subpopulação em questão, sendo que até hoje de todas as associações genéticas reportadas para degeneração discal, apenas quatro puderam ser comprovadas em mais de um grupo étnico. Por fim, discrepâncias metodológicas e diferenças quanto à própria definição do que consiste o "fenótipo" de degeneração discal atrapalham a interpretação dos resultados: em diferentes estudos, abaulamento discal, herniação, alterações em radiografias lombares ou a 
necessidade de cirurgia têm sido determinados como o "fenótipo" positivo de doença degenerativa discal ${ }^{156-158}$.

Até hoje, a maior parte dos estudos genéticos para degeneração discal se concentrou nos genes que codificam as três cadeias do colágeno IX. Estudos utilizando camundongos portadores de mutações ou deleções no gene da cadeia $\alpha 1$ do colágeno IX (gene COL9A1) já haviam revelado diversas alterações musculares, ósseas e cartilagíneas, entre elas a degeneração dos discos intervertebrais em uma idade muito precoce, com escoliose progressiva, paraplegia e morte dos animais ${ }^{159,160}$. Baseados nestes modelos animais, Annunen et al. procuraram identificar na população finlandesa mutações nos genes do colágeno IX que pudessem estar associadas com degeneração discal ${ }^{157}$. Annunen et al. partiram de 157 indivíduos selecionados com dor irradiada, dos quais 73\% possuíam comprovação radiológica de degeneração discal - surge aí um exemplo de como o "fenótipo" considerado para degeneração discal afeta os estudos de associação: tal quadro clínico permite inferir que estes indivíduos demonstravam não apenas degeneração mas também herniação ou abaulamento discal com radiculopatia. Em seis destes 157 indivíduos, uma mutação denominada Trp2 substituía um resíduo Arg ou Gln no códon 326 da cadeia $\alpha 2$ de colágeno 9 (gene COL9A2) por um resíduo Trp - uma mutação muito rara, uma vez que Trp é encontrado poucas vezes nas proteínas da classe dos colágenos e nunca especificamente em colágeno IX de mamíferos. Ao pesquisar 174 controles finlandeses assintomáticos, a mutação Trp2 não foi encontrada nenhuma vez. Estudos posteriores de famílias de pacientes finlandeses confirmaram a associação desta mutação com um maior grau radiológico de degeneração discal, embora a associação com sintomas não fosse clara $^{157,161}$. Ulteriormente, a associação entre a mutação Trp2 e degeneração discal foi descartada em uma amostra da população alemã porém comprovada nas populações do sul da China e do Japão em grupos etários específicos ${ }^{162-164168-170}$. Outras mutações com substituição de aminoácidos por resíduos Trp nos genes do colágeno IX foram descritas, mas este caso demonstra como as associações genéticas para degeneração discal variam de acordo com o grupo étnico ${ }^{164}$. 
O gene COL1A1 (17q21.3-q22) é responsável por uma das cadeias de colágeno tipo 1. Um polimorfismo (TT/GT/GG) no intron 1 deste gene, exatamente no sítio de ligação do fator de transcrição Sp1, é associado com menor densidade mineral óssea e fraturas vertebrais. A partir destas associações conhecidas, Pluijm et al. procuraram analisar a relação de polimorfismos deste gene com a prevalência de osteoporose na população holandesa ${ }^{165}$. Pluijm et al. não conseguiram identificar nenhuma relação com osteoporose; entretanto, seu protocolo de estudo envolvia a obtenção de radiografias laterais da coluna tóraco-lombar ${ }^{165}$. Utilizando-se de um antigo critério de avaliação de degeneração de discos intervertebrais em radiografias simples, Pluijm et al. afirmam que um genótipo TT para este sítio de ligação Sp1 está associado com degeneração discal. Ulteriormente, tal associação foi também demonstrada em um pequeno estudo com indivíduos gregos assintomáticos, desta vez avaliando-os com RM (ressonância magnética). Fica evidente neste caso como as diferentes definições de fenótipo positivo para degeneração discal afetam estes estudos de associação ${ }^{158,165,166}$.

O gene VDR (vitamin $D$ receptor) é outro gene envolvido no metabolismo ósseo cujas associações com anomalias do desenvolvimento de tecidos mineralizados são conhecidas de longa data. Em mais um estudo utilizando radiografias para determinar a prevalência de osteoporose, desta vez na população australiana, Jones et al. identificaram que determinados alelos para o polimorfismo Taq1 do gene VDR estão associados com degeneração discal ${ }^{158,167}$. Estes resultados foram ulteriormente confirmados utilizando RM em gêmeos finlandeses e nas populações chinesa e japonesa ${ }^{168-171}$. Entretanto, ao contrário dos genes COL1A1, COL9A2 e COL9A3, não se consegue imaginar um papel direto para os polimorfismos do gene VDR na degeneração discal. A visão mais aceita é que na verdade estes polimorfismos de VDR devem representar apenas um marcador para mutações de outros genes. O gene VDR está localizado em 12q12-q14, e tanto o gene para colágeno tipo II (COL2A1) como para IGF-1 estão localizados próximos - especificamente, a distância de VDR até COL2A1 é de menos de 740 kb. Ambos estes genes estão sabidamente envolvidos na composição e processo degenerativo do disco intervertebral, e é de se esperar que estudos genéticos futuros possam elucidar como estes genes se relacionam com os polimorfismos de VDR identificados até o momento ${ }^{158}$. 
Outra proteína para a qual foi identificada uma associação genética com degeneração discal em mais de um grupo étnico é a MMP-3. Como visto acima, acredita-se que este gene esteja envolvido no remodelamento da matriz extracelular durante o processo de degeneração discal $^{158,172}$. Os dados, porém, que suportam esta associação são bem mais tênues que para os outros 3 genes. Takahashi et al., ao estudar a presença de polimorfismos 5A/6A na região promotora do gene MMP-3, utilizou critérios diferentes para estudar um grupo jovem (RM) e um grupo idoso (radiografias simples) de 54 e 49 indivíduos, respectivamente. A presença de um genótipo 5A5A ou 5A6A nos indivíduos idosos estava associada com maior grau de degeneração, porém isto não se verificou na faixa etária mais jovem ${ }^{172}$. $O$ fato de Takahashi et al. utilizar diferentes definições radiológicas de fenótipo positivo para degeneração discal por si só já compromete severamente os dados de seu estudo; entretanto, seus resultados

foram replicados por Valdes et al. em uma amostra de 720 mulheres inglesas ${ }^{158,173}$. Como em muitos dos estudos de associação genética, este resultado não se manteve em todas as populações estudadas: na população finlandesa, Noponen-Hietala et al. não encontraram associação entre degeneração discal e os polimorfismos descritos para o promotor do gene da MMP-3 $3^{174}$.

\subsection{Características e deficiências de diferentes modelos de estudo da degeneração discal: in vitro, in vivo, por imagem e morfológicos}

Apesar de diversos modelos experimentais terem sido utilizados ao longo destes quase 160 anos no estudo da degeneração discal, um único modelo definitivo provavelmente nunca será encontrado. Cada modelo experimental possui características e limitações próprias e é a combinação entre as diferentes informações fornecidas através de cada um deles que permitirá o entendimento da degeneração discal. Muito se contribuiu através de modelos in vitro, particularmente quanto ao microambiente celular do disco intervertebral. Através destes modelos de cultura de células e tecidos, animais ou humanos, aspectos importantes do processo degenerativo foram elucidados, como a modulação do mesmo pelas próprias 
células do disco e os diferentes padrões de expressão protéica e gênica ${ }^{175}$. Já modelos biomecânicos in vitro são ideais para análise de carga e pressões não só sobre o disco intervertebral mas também sobre as facetas. Dados sobre as modificações das propriedades mecânicas dos discos degenerados, por exemplo, foram obtidas através de estudos biomecânicos in vitro, e são nestes mesmos modelos que as principais intervenções cirúrgicas são testadas antes de serem validadas in vivo ${ }^{175,176}$.

Qualquer revisão rápida da literatura sobre degeneração discal irá revelar uma grande quantidade de modelos animais para estudos in vivo da degeneração discal. Estes permitem um controle de condições experimentais e reproducibilidade de resultados que não é possível com nenhum outro tipo de estudo, embora considerações éticas e de custos envolvidos sejam relevantes. Os modelos in vivo de degeneração discal podem ser divididos entre aqueles em que a degeneração ocorre naturalmente ou é provocada por intervenção humana. Sabe-se que os discos de todos estes animais possuem diferenças morfológicas em relação aos humanos, como em sua população celular ${ }^{177}$. Dentre os modelos naturais, sabese que alguns roedores (ratos de areia), cachorros (raças condrodistróficas, como beagle e basset hound) e primatas (babuínos) exibem graus variados de degeneração espontânea. Muitos pesquisadores aproveitaram-se disso para elucidar diversos aspectos morfológicos da degeneração discal e a principal vantagem é que a degeneração espontânea seria mais similar à humana, em oposição à degeneração provocada ${ }^{178,179}$. Ainda assim, em todos estes modelos a degeneração provou-se razoavelmente distinta da humana: por exemplo, embora os discos de cães condrodistróficos desenvolvam alterações de matriz extracelular e diminuição de conteúdo de proteoglicanas similares aos humanos, esta matriz se calcifica logo em seguida na quase totalidade dos casos. No caso do babuíno, a coluna destes animais exibe uma cifose progressiva que poderia afetar o padrão de degeneração. Talvez mais importante, a incerteza acerca quais animais e níveis de suas colunas irão desenvolver degeneração discal significativa faz com que estes trabalhos empreguem uma quantidade muito grande de animais e utilize exames de imagem de maneira liberal, aumentando os custos em demasia e tornando-os impopulares ${ }^{178-181}$. Já modelos experimentais in vivo com degeneração induzida envolvem basicamente roedores, seja através de intervenções cirúrgicas (alterações posturais, suspensão da cauda, lesão do disco por agulha ou bisturi, 
torção segmentar, ressecção de faceta ou artrodese em nível adjacente) ou intervenções genéticas (basicamente os diversos modelos knock-out, com deleções de genes importantes para o processo degenerativo - por exemplo, colágeno II ou IX). Apesar de permitirem a maior reproducibilidade de resultados, a degeneração ocorre de maneira artificial. Embora isto possa mimetizar algumas situações de degeneração secundária como, por exemplo, após a injeção para discografia, dificilmente as lições aprendidas através destes modelos aplica-se diretamente a humanos. Como Alini et al. recentemente apontaram, todos estes animais diferem de nós em dois pontos fundamentais - a postura ereta e a maneira com que interpretamos e lidamos com a dor ${ }^{175,182}$.

São, portanto, apenas os modelos humanos que permitem o estudo da degeneração conforme os clínicos irão encontrar em sua prática diária. Desde o princípio do século XX, imaginou-se estudar seres humanos através de exames de imagem; o famoso estudo pioneiro é de Schmorl e Junghanns $(1932)^{34}$. Estas técnicas permitiam a avaliação de indivíduos levando-se em conta suas queixas funcionais e divisão conforme a mesma; ainda hoje é impossível dividir animais em grupos sintomáticos e assintomáticos para degeneração discal simples. Além disso, a observação seriada tornou-se possível e diversas formas de classificar os achados degenerativos foram criadas. Talvez a classificação radiográfica mais famosa para degeneração discal seja aquela de Kellgren - entretanto, como todas as classificações baseadas em análise por métodos de raios- $X$, baseia-se ultimamente em avaliações indiretas acerca dos discos intervertebrais como altura do espaço intervertebral e presença de osteófitos marginais ${ }^{182}$. Começando em 1984, estudos por ressonância magnética (RM) passaram a ser empregados para avaliação da degeneração discal ${ }^{183}$. A partir de uma série de estudos pioneiros de Modic et al. no final dos anos 1980, as alterações associadas com degeneração discal foram descritas na literatura. Nestes estudos, os autores não só demonstraram as mesmas alterações descritas na seção 1.5 sob este novo método como, a partir das características de imagem da RM, puderam adicionar alterações de sinal do NP (próprias de seu processo de desidratação) e alterações da medula óssea das vértebras adjacentes como critérios de avaliação de degeneração. Ao dividir estas alterações em dois subgrupos e sugerir uma evolução temporal entre eles, Modic et al. propuseram uma correlação com sintomas: em particular, alterações de sinal da medula óssea adjacente 
(hipersinal em T1 e iso / leve hipersinal em T2), as chamadas alterações "Tipo 2" de Modic, seriam particularmente associadas com sintomas de lombalgia ${ }^{91,183,184}$.

A RM rapidamente tornou-se o exame de escolha para avaliação da degeneração discal em qualquer nível. Além disso, ao permitir o seguimento temporal das alterações de imagem sem o uso de radiação ionizante em um mesmo indivíduo, com ou sem sintomas, tornou-se importante ferramenta para estudos de prevalência destas alterações. Estudos por RM contribuíram para uma das maiores controvérsias em degeneração discal, que é o elevado número de indivíduos assintomáticos que exibem as mesmas alterações degenerativas citadas nas seções anteriores. O primeiro estudo demonstrando estas alterações assintomáticas por RM foi publicado por Boden et al. inicialmente no segmento lombar e logo após, no cervical ${ }^{139,140}$. Em seu estudo inicial de 67 voluntários assintomáticos estratificados por idade, Boden et al. reporta alterações "substanciais" destes exames de RM em $28 \%$ destes indivíduos: estenose lombar em $24 \%$ e herniação franca do NP em outros 4\%. Alterações degenerativas "menores", como abaulamento discal, diminuição da altura discal e alteração de sinal em T2 foram vistas em pelo menos $57 \%$ dos indivíduos jovens (2039 anos), enquanto que 93\% dos voluntários acima de 60 anos de idade possuíam estas alterações em pelo menos um disco (média: 3,0 discos). Especificamente, dois terços de todos os discos estudados em indivíduos idosos (60/90) apresentavam sinais de degeneração. Boden et al. estudaram ainda a coluna cervical de 63 destes 67 voluntários, também assintomáticos para queixas desta região. Mais uma vez, alterações "importantes" (herniações discais ou estenose central) foram vistas em $19 \%$ dos indivíduos, aumentando com a idade ( $14 \%$ naqueles com idade menor que $40,28 \%$ com idade maior que 40 ). A prevalência de ao menos um disco degenerado entre C2 e C7 foi de $25 \%$ em indivíduos mais jovens que 40 anos e $57 \%$ após esta idade ${ }^{139,140}$.

Com estes estudos de RM, estabeleceu-se definitivamente o que já se havia demonstrado indiretamente por radiografias, CT e mielografia: alterações degenerativas discais estavam presentes em um grande número de indivíduos assintomáticos. O seguimento temporal destas alterações revelou também a progressão destas alterações sem o surgimento de 
sintomas. Na maior coorte reportada na literatura, Matsumoto et al. realizaram RM da coluna cervical em 497 voluntários assintomáticos entre 1993 e 1996 para um total de 2480 discos ${ }^{185}$. Seus achados corroboraram aqueles de Boden et al. e vários outros na literatura: degeneração discal em pelo menos um nível foi encontrada em $17 \%$ e $12 \%$ dos homens e mulheres com idade menor que 20 anos e em $89 \%$ e $86 \%$ daqueles com idade maior que 60 $\operatorname{anos}^{140,185,186}$. Alterações degenerativas mais graves, com herniação discal e compressão medular estava presente em 7,6\% dos voluntários acima de 60 anos $^{185}$. Duzentos e vinte e três destes voluntários $(44,9 \%)$ foram localizados ulteriormente e submetidos a uma nova RM em média 11,7 anos após a inicial. A progressão das alerações degenerativas foi observada em $81,1 \%$ dos voluntários (189 indivíduos). A divisão por tipo de alteração adicional sempre revelou valores elevados: diminuição de sinal de disco em 59,6\%, protrusão discal posterior em $70 \%$, diminuição da altura discal em $26,9 \%$ e estenose foraminal em 9\%. A única correlação entre degeneração discal e fatores predisponentes foi feita com idade. Não se demonstrou correlação alguma com gênero, uso de álcool, atividade física, índice de massa corpórea ou, surpreendentemente, tabagismo. Destes 189 individuos em que progressão radiológica foi demonstrada, apenas $34,1 \%$ desenvolveu sintomas como cervicalgia ou radiculopatia, provando assim que a progressão temporal pode acontecer e que a ausência de sintomas é a regra. Estes fatos são bem conhecidos na prática clínica, e estes indivíduos apresentaram ainda progressão das alterações degenerativas no segmento torácico; infelizmente, os dados do segmento lombar desta coorte não foram publicados $^{187,188}$.

A partir da revisão acima, torna-se evidente que muito há por pesquisar quanto à degeneração discal em indivíduos assintomáticos, e os trabalhos morfológicos com espécimes humanos possuem papel bastante proeminente neste avanço. Infelizmente, como apontado em diversos setores da seção 1.6, muitos problemas com os espécimes humanos comprometem os resultados destes estudos morfológicos ${ }^{56}$. A necessidade de maior conhecimento histológico e ultraestrutural é amplamente reconhecida na literatura para que se correlacione com os achados moleculares e de indivíduos sintomáticos ${ }^{53}$. 


\subsection{Particularidades dos discos do segmento cervical}

Além das dificuldades de padronização dos espécimes "controle", as generalizações aplicadas aos discos intervertebrais do segmento cervical também prejudicam a compreensão do processo degenerativo neste segmento. Conforme revisado na seção 1.1, a importância clínica da cervicalgia é quase tão grande quanto à lombalgia. É fato inconteste que tanto a morfologia quanto a função dos discos intervertebrais do segmento cervical são distintos daqueles do segmento lombar; ainda assim, a quantidade de estudos morfológicos próprios para os discos deste segmento é desapontadora ${ }^{189}$. Pior ainda, a extrapolação dos dados lombares é feita livremente para o segmento cervical sem o menor critério - em uma publicação de 1992, presumivelmente dedicada especificamente à degeneração discal cervical, cinco das seis figuras utilizadas para ilustrar o artigo eram, na verdade, de espécimes lombares ${ }^{190}$. Ainda hoje não são incomuns estudos morfológicos que utilizam espécimes cervicais e lombares de maneira indiscriminada, oriundos de centros com bastante tradição em pesquisa de degeneração discal ${ }^{191,192}$.

Pelos relatos cirúrgicos de meados do século $X X$, é nítido que os cirurgiões percebiam a diferença entre a morfologia dos discos cervicais quando comparados com os lombares Cloward e Scoville comentaram estas diferenças em duas obras dirigidas ao tratamento cirúrgico $^{133,146,193}$. Testut em 1905 já fez menção ao formato diferente do disco de acordo com o nível em questão ${ }^{27}$. Os primeiros estudos anatômicos dirigidos às peculiaridades dos discos cervicais foram publicados por Töndury em $1961^{194,195}$. Töndury brevemente comentou sobre o padrão distinto de degeneração e espondilose em nível cervical, quando comparado ao lombar: herniações francas são incomuns neste segmento, onde a compressão foraminal ou central usualmente se dá por um complexo disco-osteofitário. Além disso, reportou a presença freqüente de fendas no disco cervical a partir da idade de 33 anos; isto confere ao disco cervical um formato único, bipartido ${ }^{194}$. Alguns pequenos trabalhos anatômicos foram publicados após as descrições de Töndury enfatizando aspectos específicos do disco cervical. Pooni et al. analisaram as diferentes orientações das lamelas do 
AF cervical ${ }^{196}$. A menor contribuição do NP (25\%) ao total do disco, em relação ao NP lombar (50\%), foi relatada inicialmente por Oda em 1988, além de constatar que o material nuclear cervical torna-se indistinto do AF a partir da quarta década de vida, fato ulteriormente confirmado com diferente metodologia por Mercer e Bogduk ${ }^{189,197}$. Bland e Boushey publicaram uma análise do padrão macroscópico de degeneração não só de discos mas de segmentos cervicais de uma série de cadáveres: esclerose da placa vertebral, protrusão discal e osteófitos oriundos do corpo vertebral ou articulações uncovertebrais ou zigoapofisárias (articulação dos processos articulares) são as características degenerativas mais comumente encontradas em nível cervical ${ }^{198}$.

O trabalho morfológico mais completo acerca das peculiaridades dos discos intervertebrais cervicais foi publicado por Mercer e Bogduk no final do século passado ${ }^{189}$. Estudando um número modesto de cadáveres (12) predominantemente idosos (média de idade 65,4 anos, de 39 a 82), Mercer e Bogduk descreveram detalhadamente a anatomia dos ligamentos longitudinais e AF dos discos do segmento cervical em nível macroscópico. Neste nível, o LLA é composto por quatro camadas, sendo as três mais externas com disposição longitudinal e a mais interna, com disposição diagonal e pouco distinta das fibras do AF. Já o LLP é composto por três camadas: uma camada superficial, atravessando vários níveis com orientação longitudinal e extensão lateral até os pedículos, uma camada média longitudinal curta atravessando apenas um espaço intervertebral e uma camada profunda análoga à do LLA, com disposição diagonal, curta. As principais contribuições de Mercer e Bogduk, entretanto, se fizeram no estudo da morfologia do AF do segmento cervical. Pela primeira vez, sua estrutura em forma de foice foi descrita: mais espesso anteriormente e fina em sua porção posterior, particularmente junto aos processos uncinados, póstero-lateralmente. A própria distinção entre as camadas mais internas do LLA e LLP e as camadas mais externas não era absolutamente nítida: Mercer e Bogduk utilizaram como critério final a inserção destas fibras, se às superfícies verticais (anterior ou posterior), e portanto parte dos ligamentos longitudinais, ou se às superfíes horizontais das vértebras, e assim parte do AF. Nas fibras mais internas da porção anterior, não se evidenciou um padrão de alternância de fibras longitudinais / circulares, mas sim uma disposição diagonal, entremeadas umas às outras. Já a porção posterior do AF consistia em uma única camada longitudinal, bastante 
delgada (não mais de $1 \mathrm{~mm}$ de espessura) estendendo-se entre as bases dos processos uncinados lateralmente. Sobre estes processos uncinados especificamente o AF tornava-se descontínuo, restando apenas uma camada de tecido periosteal ${ }^{189}$. Profundamente ao AF, Mercer e Bogduk descrevem uma massa rígida de composta por matriz de proteoglicana que oferecia resistência à dissecção; como, a partir deste fato, concluíram a respeito de sua composição não está claro. Esta massa apresentava fendas bilateralmente sobre os processos uncinados - fendas estas que já haviam sido descritos na primeira década de vida por Hirsch et al. e mesmo Töndury ${ }^{194,199}$. Estas fendas têm sido interpretadas como surgindo na primeira década de vida seja para permitir ou como consequência dos repetidos movimentos de rotação nesta região ${ }^{189,198}$. Apesar de tratar-se de uma população idosa, Mercer e Bogduk apresentam um dos poucos estudos anatômicos especialmente dirigido ao disco intervertebral em nível cervical, ainda que consistindo em uma análise macroscópica.

Considerando-se a importância da cervicalgia como problema de saúde pública, surpreende a escassez de estudos morfológicos, particularmente empregando análise histológica, em discos intervertebrais cervicais humanos: estudos de imagem em indivíduos assintomáticos $^{200}$ e histológicos ou imuno-histoquímicos em espécimes cirúrgicos ${ }^{201,202}$ são abundantes na literatura. Christe et al. publicariam em 2005 o único estudo em língua inglesa acerca da histologia geral do disco intervertebral cervical em indivíduos assintomáticos $^{203}$. Maruyama e Gen também publicaram artigos nos anos 1990s que supostamente conteriam análises histológicas de discos cervicais de cadáveres assintomáticos de diferentes idades; o fato de terem sido publicados na língua japonesa restringe $\mathrm{o}$ acesso a estes dados ${ }^{204-206}$. Christe et al. analisaram nove cadáveres por radiografia, RM e histologia. Sua análise histológica empregou apenas uma técnica (HE) e extrapolou uma escala de gradação lombar para a coluna cervical ${ }^{203}$. Um dado que compromete severamente o estudo de Christe et al. é simplesmente a ausência da idade dos cadáveres, citados apenas como "acima de 50 anos". Portanto, é muito difícil correlacionar quaisquer dados histológicos. Christe et al. reportaram a existência de fissuras radiais em $64 \%$ dos discos estudados (34/52), completas no sentido ântero-posterior em mais da metade dos discos (27/52). Outros achados morfológicos incluíram prolapso $(74 \%$ dos discos), tecido de granulação com neovascularização (33\%) e osteófitos (52\%). Estes achados 
foram descritos com o objetivo de se classificar histologicamente o disco conforme Berlemann et al., para subsequentemente serem correlacionados com uma classificação de imagem não-padronizada. Pela frequência das alterações degenerativas detectadas na histologia, metade dos espécimes recebeu a classificação máxima de Berlemann; dada a ausência de correlação etária, o valor deste dado é incerto. Através da análise de RM, principal objetivo de seu trabalho, Christe et al. concluíram que a RM detecta prolapsos discais e osteófitos muito bem mas apenas $40 \%$ das fissuras, consistentemente subestimando a presença de alterações degenerativas do disco ${ }^{203}$.

Esta análise de Christe et al. emprega apenas uma técnica histológica para estudo de organização geral, mesmo porque não era o objetivo principal de seu trabalho ${ }^{203}$. Análises específicas de diferentes componentes dos discos cervicais são ainda mais raras; apenas um estudo, histológico ou de qualquer outro método, pode ser encontrado a respeito do sistema elástico, por exemplo. Após relatos iniciais não terem detectado a presença de fibras elásticas em discos intervertebrais humanos ${ }^{207}$, Buckwalter et al. identificaram-nas em espécimes obtidos de cirurgia para escoliose e herniação, através de microscopia eletrônica de transmissão - estes autores nunca especificaram os níveis de origem destes espécimes, e pelas indicações presume-se que sejam torácicos ou lombares ${ }^{208}$. Assim, em 1982 Johnson et al. buscaram identificar fibras elásticas em 48 discos cervicais removidos de 12 cadáveres com idade entre 50 e 80 anos $^{209}$. Utilizaram para isso a técnica de Verhoeff e detectaram fibras elásticas abundantes no AF, mas apenas onde este se inseria na placa vertebral, com presença mínima na região do NP e sua interface com a placa vertebral. Johnson et al. descreveram também a orientação longitudinal destas fibras elásticas, alinhadas com as lamelas de fibras colágenas e compararam sua inserção na placa vertebral às fibras de Sharpey de outros ossos, como já feito por Coventry et al. com as fibras colágenas ${ }^{1,209}$. Não foi realizada quantificação destas fibras e Johnson et al. reportam-nas como "presentes e abundantes" em todos os espécimes nas regiões supracitadas. Infelizmente, depois de Johnson et al. não se encontra na literatura nenhum trabalho acerca das fibras elásticas em discos cervicais humanos. 


\subsection{Contribuições brasileiras ao estudo da degeneração discal}

São encontrados na literatura poucos estudos em degeneração discal com contribuição brasileira. Estes poucos estudos, entretanto, são de linhas bastante variadas e atuais, o que mostra sincronia com as principais linhas de pesquisa mundiais. Além disso, são oriundos de diferentes centros de pesquisa no Brasil, o que mostra a difusão da pesquisa em degeneração discal e reflete a ampla distribuição geográfica deste problema de saúde pública.

Um exemplo disso é o estudo de associação genética de Nunes et al. ${ }^{210}$. Estes autores demonstram uma associação genética entre determinados polimorfismos do gene VDR e degeneração discal acentuada em nível lombar. Em que pese o fato de sua população controle não ter sido avaliada por exame de imagem, ao contrário da população sintomática, Nunes et al. confirmam dados já revisados na seção 1.6.5. Há alguns exemplos de trabalhos morfológicos, como Oliveira et al., que correlacionaram a presença de terminações nervosas no interior de discos lombares com diferentes graus de degeneração ou Vialle et al., que replicaram e revalidaram um modelo de degeneração discal em coelhos ${ }^{211-213}$. Um exemplo de estudo biomecânico com contribuição brasileira é o trabalho de Schechtman et al., embora realizado na Nova Zelândia, que analisou os critérios de falência estrutural de discos de cauda de bovinos ${ }^{214}$. Estudos de análise de imagem no segmento lombar também se fizeram presentes através de Puertas et al. (estudando os mesmos espécimes ulteriormente analisados por Oliveira et al.) e Maurer et al.., que relataram sobre a incidência de alterações assintomáticas em indivíduos que realizavam esforço físico (remadores) ${ }^{215,216}$.

Por fim, a única contribuição brasileira em nível cervical se deu a partir de um trabalho da Universidade de São Paulo, especificamente da Faculdade de Medicina de Ribeirão Preto. Ao analisar as alturas de discos cervicais e suas placas vertebrais, Vieira et al. detectaram uma correlação entre a altura da placa vertebral e a altura do disco ao qual pertence mas não 
com a altura da outra placa vertebral da mesma vértebra, sugerindo assim que a degeneração depende mais da biologia discal e não vertebral ${ }^{217}$. 
2 Objetivos e Hipóteses 
Avaliar e comparar, quanto à sua morfologia, os discos intervertebrais cervicais e lombares de indivíduos presumivelmente assintomáticos, obtidos de necrópsias de homens e mulheres jovens ( Grupo Jovem - $\underline{\mathbf{G J}}$ - idade menor que 35 anos) e idosos (Grupo Idoso - $\mathbf{G I}$ - idade maior que 65 anos). Para tanto utilizou-se técnicas de análise por macroscopia, ressonância magnética, microscopias de luz e eletrônica de varredura (MEV) e imunohistoquímica.

Através destas análises, foram testadas duas hipóteses:

1) Os discos cervicais e lombares diferem em sua morfologia e composição;

2) O envelhecimento normal dos discos intervertebrais produz alterações morfológicas distintas de acordo com o segmento vertebral a que pertencem. 


\subsection{Obtenção e fixação dos espécimes}

O estudo foi aprovado pela Comissão de Ética em Pesquisa com Seres Humanos do ICB-USP em 13/11/2007 (Parecer 811/CEP). Trinta cadáveres foram incluídos neste estudo: quinze com idade inferior a 35 anos (grupo jovem - GJ) e quinze com idade superior a 65 anos (grupo idoso - Gl). Os espécimes foram obtidos no Serviço de Verificação de Óbitos (SVO), na Faculdade de Medicina da Universidade de São Paulo, durante necrópsias de rotina. Familiares de todos os indivíduos assinaram um termo em que consentiam com a extração dos espécimes para pesquisa. Na mesma ocasião, estes familiares forneceram informações que permitiram identificar cadáveres sem história de dor referida em trajeto radicular ou localizada na região cervical ou lombar, intervenções cirúrgicas nas mesmas regiões, doenças neoplásicas ou reumatólogicas e história de trauma. Além disso, durante a inspeção inicial foram excluídos cadáveres com deformidades evidentes destas regiões, bem como cadáveres onde a causa mortis final fosse de natureza neoplásica. Obtiveram-se ainda os dados pessoais e antropométricos de cada cadáver (número SVO, idade, gênero, peso, altura - Tabela 1). Os grupos foram estatisticamente semelhantes quanto às variáveis contínuas

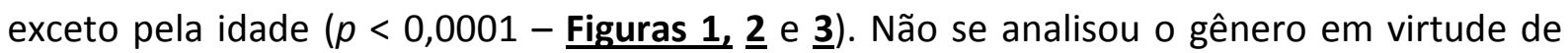
possível viés de seleção (mortalidade maior para o sexo masculino em faixa etária jovem, mesmo excluídas as causas externas). Os indivíduos de $\underline{\mathbf{G l}}$ demonstraram tendência para menor altura, ainda que não estatisticamente significante $(p=0,055)$, como seria de se esperar em população mais idosa.

De acordo com as normas do SVO, as dissecções precisam ser realizadas sem sinal externo de mutilação. Assim, a dissecção cervical foi iniciada através de incisão biacromial anterior "em colar", rebatendo-se cranialmente a pele, tecido subcutâneo e platisma. Retirado o feixe traqueo-esofágico, expôs-se o aspecto anterior da coluna vertebral em seu segmento cervical. A numeração das diferentes vértebras e discos se deu a partir da identificação do áxis e seu processo odontóide. Desarticulações através dos discos intervertebrais e articulações dos processos articulares entre C3 e C4 e entre C6 e C7 permitiram o 
Tabela 1 - Dados dos grupos GJ e Gl: idade (anos), gênero, altura (cm) e peso (kg). Abreviaturas - M: Masculino; F: Feminino.

\begin{tabular}{|c|c|c|c|c|}
\hline $\begin{array}{c}\text { Número SVO } \\
\text { espécime }\end{array}$ & Idade & Gênero & Altura & Peso \\
\hline \multicolumn{5}{|l|}{ Grupo Jovem } \\
\hline $300 / 08$ & 33 & $M$ & 168 & 65 \\
\hline $314 / 08$ & 34 & $M$ & 175 & 75 \\
\hline $479 / 08$ & 33 & $M$ & 160 & 75 \\
\hline $2780 / 08$ & 34 & $M$ & 180 & 75 \\
\hline $2781 / 08$ & 27 & M & 170 & 60 \\
\hline $2788 / 08$ & 29 & $\mathrm{~F}$ & 162 & 70 \\
\hline $6040 / 08$ & 34 & $M$ & 180 & 85 \\
\hline $9386 / 08$ & 32 & $\mathrm{~F}$ & 170 & 70 \\
\hline $11243 / 08$ & 26 & $M$ & 185 & 80 \\
\hline $11250 / 08$ & 29 & $M$ & 180 & 65 \\
\hline $1767 / 09$ & 34 & $\mathrm{~F}$ & 165 & 45 \\
\hline $4410 / 09$ & 32 & $M$ & 180 & 88 \\
\hline $4413 / 09$ & 32 & $M$ & 170 & 49 \\
\hline $5050 / 09$ & 34 & $\mathrm{~F}$ & 162 & 106 \\
\hline $5091 / 09$ & 34 & $M$ & 182 & 80 \\
\hline Média Grupo Jovem & 31,8 & & 172,6 & 72,53 \\
\hline \multicolumn{5}{|l|}{ Grupo Idoso } \\
\hline $320 / 08$ & 85 & $M$ & 178 & 75 \\
\hline $321 / 08$ & 80 & $M$ & 170 & 50 \\
\hline $323 / 08$ & 66 & $\mathrm{~F}$ & 165 & 65 \\
\hline $478 / 08$ & 67 & $M$ & 180 & 120 \\
\hline $482 / 08$ & 71 & $\mathrm{~F}$ & 155 & 40 \\
\hline $2786 / 08$ & 68 & $M$ & 165 & 60 \\
\hline $2787 / 08$ & 86 & $M$ & 165 & 65 \\
\hline $2789 / 08$ & 76 & $\mathrm{~F}$ & 162 & 70 \\
\hline $2790 / 08$ & 89 & $\mathrm{~F}$ & 155 & 66 \\
\hline $5981 / 08$ & 79 & $\mathrm{~F}$ & 160 & 65 \\
\hline $6042 / 08$ & 71 & $M$ & 180 & 75 \\
\hline $8354 / 08$ & 79 & $\mathrm{~F}$ & 160 & 40 \\
\hline $8356 / 08$ & 83 & $M$ & 180 & 110 \\
\hline $8358 / 08$ & 81 & $M$ & 165 & 80 \\
\hline $4411 / 09$ & 91 & $\mathrm{~F}$ & 150 & 45 \\
\hline Média Grupo Idoso & 78,1 & & 166,0 & 68,4 \\
\hline
\end{tabular}


isolamento de um único bloco vertebral contendo as vértebras C4, C5 e C6, bem como os discos $\mathrm{C4C5}$ e $\mathrm{C5C6}$ em seu interior, sendo que, ocasionalmente, um disco adjacente pode ter sido removido também, principalmente no caso de discos anquilosados. A dissecção das inserções musculares permitiu a remoção final de tal bloco. Os discos C4C5 e C5C6 foram selecionados por terem sido os discos com maior grau de degeneração no estudo de Kokubo et al. ${ }^{202}$. No segmento lombar, laparatomia longitudinal anterior e acesso transperitoneal levaram à exposição da coluna vertebral em seu segmento lombar. A remoção de vísceras e vasos como aorta e veia cava, artérias e veias ilíacas comuns, levou à clara identificação do sacro e concomitante exposição dos corpos vertebrais de L4 e L5. A dissecção das inserções musculares, desarticulação do disco e articulações dos processos articulares L3-L4 e osteotomias das asas do sacro permitiram a remoção de um bloco vertebral único contendo os discos L4L5 e L5S1 em seu interior (Figura 4).

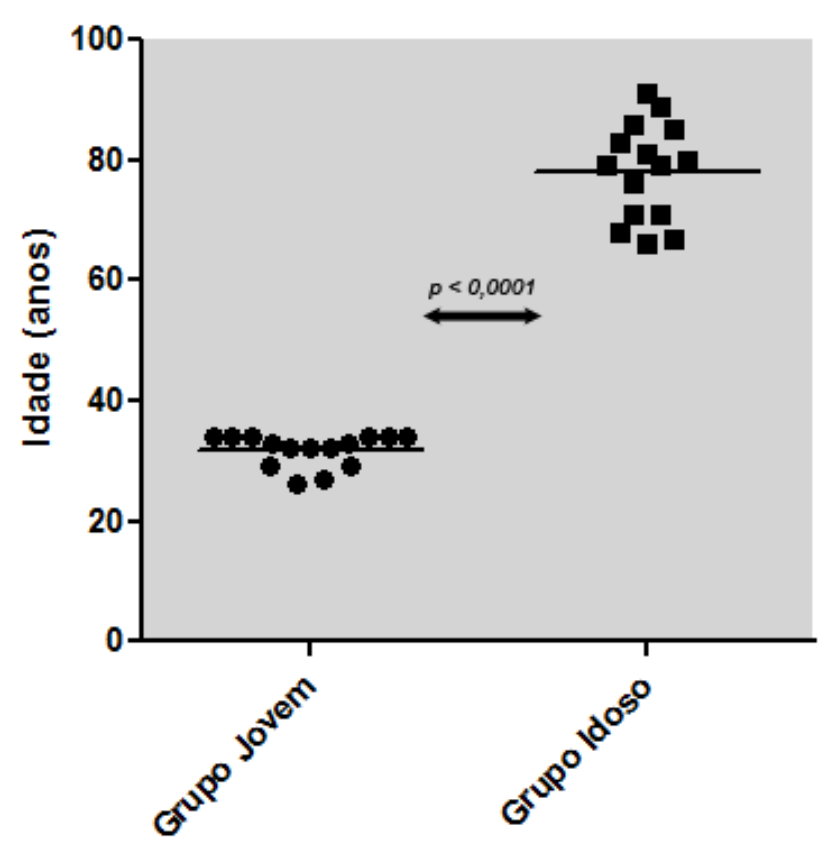

Figura 1 - Gráfico de distribuição das idades de $\underline{\text { GJ }}$ e $\underline{\text { GI }}$ (barras horizontais em cada coluna demonstram a média). 


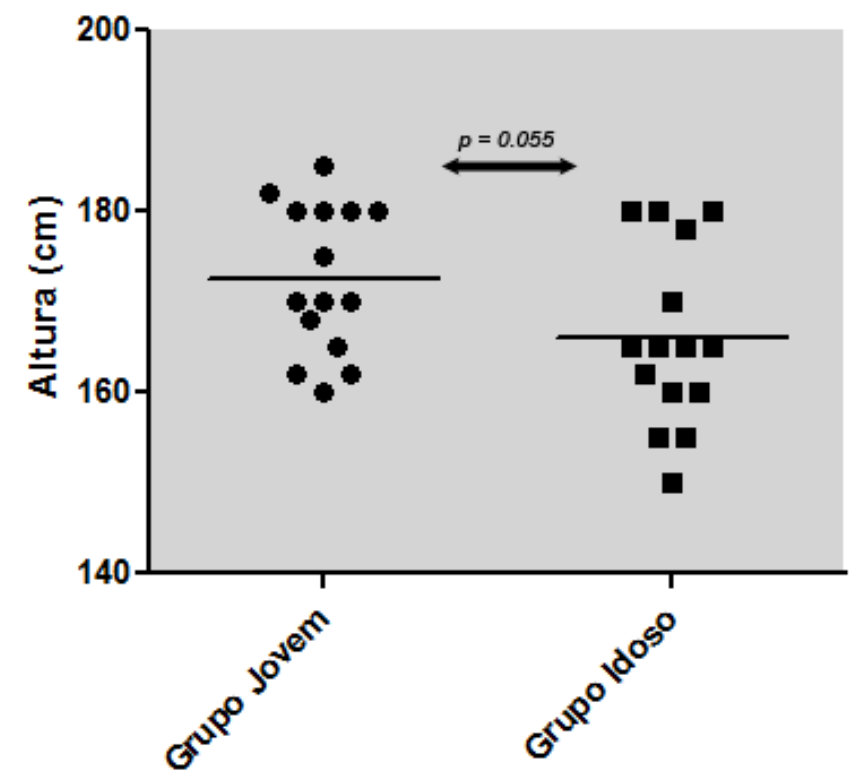

Figura 2 - Gráfico de distribuição de GJ e GI (barras horizontais em cada coluna demonstram a média).

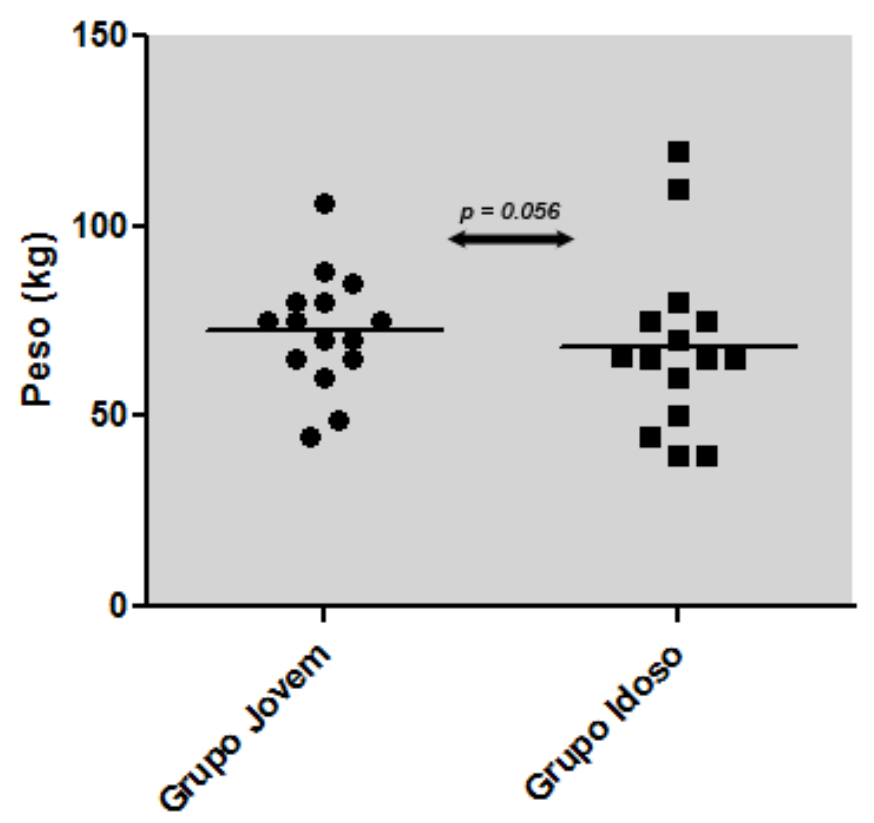

Figura 3 - Gráfico de distribuição de $\underline{\text { GJ }}$ e $\underline{\text { GI }}$ (barras horizontais em cada coluna demonstram a média). 
Uma vez removidos, os blocos vertebrais foram levados ao Laboratório de Anatomia aplicada à Clínica e Cirurgia do ICB-USP e submetidos à seguinte metodologia de mascaramento: um integrante do laboratório, sem envolvimento com o trabalho, atribuiu a cada indivíduo um novo identificador, através do qual tal espécime seria referido ao longo do projeto. Assim, os pesquisadores desconheciam a que grupo tal espécime pertencia. Estes espécimes foram então fixados em formaldeído a 4\% por um período mínimo de 6 meses.
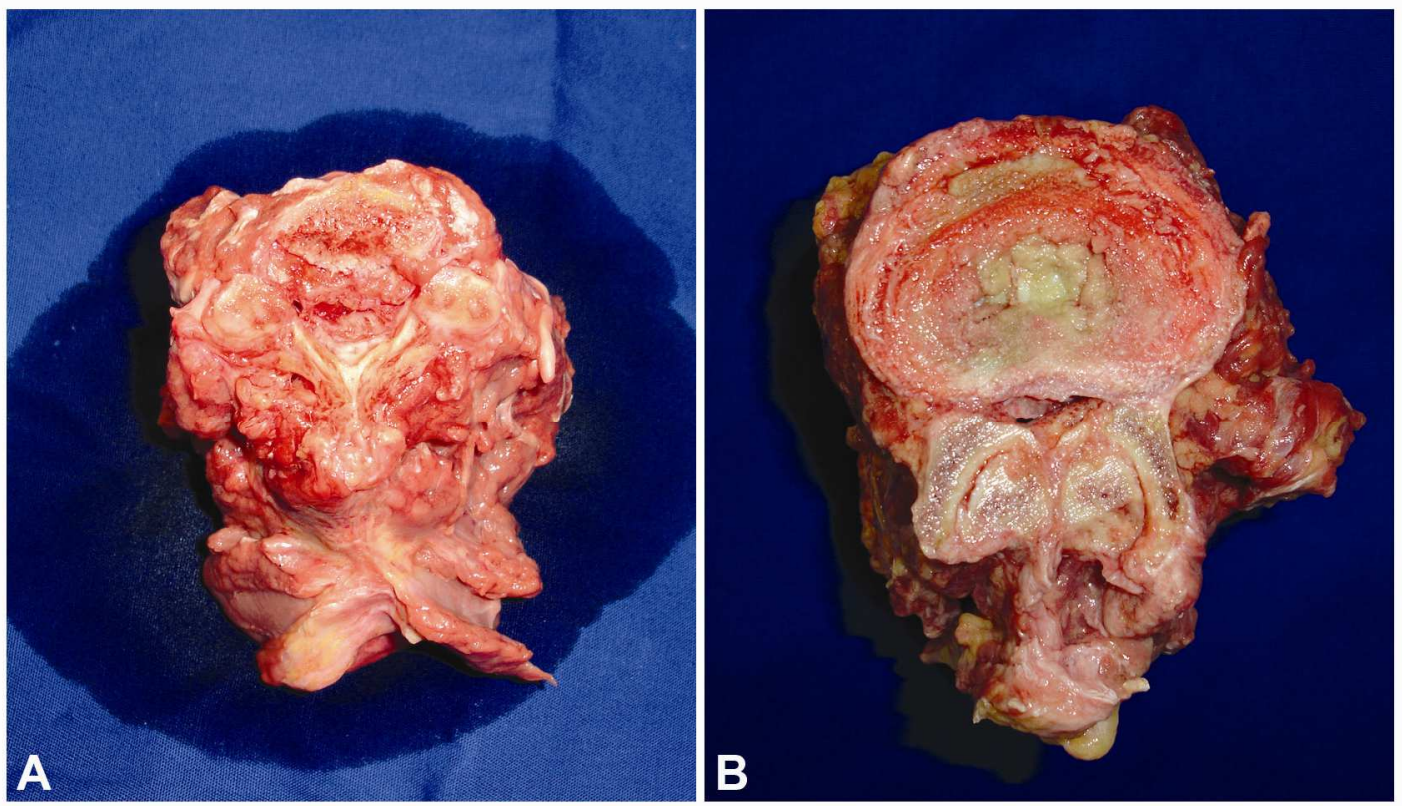

Figura 4 - Vista superior dos blocos vertebrais após desarticulações e osteotomias. Bloco cervical, espécime 8354 (스) e bloco lombar, espécime 8358 (4B).

\subsection{Avaliação por Ressonância Magnética}

Cinco espécimes de cada grupo foram selecionados de maneira aleatória para avaliação por RM. Como a maioria das escalas morfológicas que utilizam RM empregam a sequência T2, buscoup-se replicá-la nos espécimes do presente estudo ${ }^{218-220}$. Entretanto, em virtude do 
pequeno tamanho dos mesmos e peculiaridades do tipo de scanner utilizado, os padrões comumente aplicados para obtenção desta sequência necessitaram ser adaptados. Sendo assim, foi realizado um estudo piloto no scanner de ressonância magnética do Instituto de Física da Universidade de São Paulo (Philips Gyroscan ACS II/15, 1,5 Tesla, Eindhoven, Holanda) com três espécimes, a partir de referências conhecidas da literatura ${ }^{219}$, chegandose aos seguintes parâmetros: matrix $=512 \times 225, T R / T E=5000 / 130 \mathrm{~ms}$, field of view $=140 \mathrm{x}$ $140 \mathrm{~mm}$, slice thickness $=2 \mathrm{~mm}^{219,221}$. Imagens no plano sagital mediano e axiais ao nível de cada disco cervical e lombar foram obtidas dos blocos cervicais e lombares de cinco indivíduos de cada grupo. Todos os discos foram avaliados conforme Matsumoto et al., descrevendo-se seu sinal na RM em relação ao sinal de água ou líquido céfalorraquidiano em seu trabalho, daí derivando os termos hipo- ou hipersinal ${ }^{185}$.

\subsection{Análise morfológica e descalcificação}

Após coleta no SVO, fixação e, quando selecionados, avaliação por ressonância magnética, os discos foram seccionados no plano sagital mediano, fotografados e submetidos à análise morfológica. Uma recente revisão identificou 42 escalas diferentes de avaliação morfológica para discos intervertebrais ${ }^{218}$. A escala morfológica mais utilizada é a escala de Thompson, descrita em 1990, que, após extensa análise estatística, foi considerada a única escala morfológica com reproducibilidade intra- e inter-observador satisfatória para ser empregada em estudos científicos ${ }^{221}$. Esta escala, embora descrita para secções sagitais em nível lombar, é rotineiramente extrapolada para uso cervical, em virtude de seus critérios não incluírem nenhuma característica anatômica exclusivamente lombar, além de não existir nenhuma escala morfológica própria do segmento cervical amplamente aceita ${ }^{218}$. Resumidamente, quatro locais do conjunto disco-vértebra (núcleo, anel fibroso, placa e corpo vertebrais) recebem graduações de 1 a 5 baseado no aspecto morfológico, em ordem crescente de alterações encontradas em indivíduos mais idosos e portanto teoricamente mais “degeneradas" 221 . Este esquema de gradação está exposto no Quadro 1 adaptado para o português. Não fica claro por Thompson et al. se as gradações são somadas e a média 
utilizada ou se a pior classificação individual é a considerada. Seguindo recomendação de Kettler e Wilke, a pior classificação de um subgrupo justificou a inclusão deste disco em uma categoria geral mais deteriorada ${ }^{218,221}$.

Após a gradação morfológica, cada hemi-disco foi separado em unidades individuais compostas pelo hemi-disco com suas placas vertebrais adjacentes até o osso medular do corpo vertebral. Foi realizada então descalcificação através de imersão em solução de ácido etilenodiaminotetraacético (EDTA) 0,25M por 1 mês, completada por um segundo período em EDTA 0,5M por 5 dias antes da análise histológica ${ }^{53}$.

Quadro 1 - Classificação morfológica de Thompson.

\begin{tabular}{|c|c|c|c|c|}
\hline Grau & Núcleo & Anel & Placa vertebral & Corpo vertebral \\
\hline 1 & Gel, formato convexo & $\begin{array}{ll}\text { Lamelas } & \text { fibrosas } \\
\text { discretas } & \end{array}$ & $\begin{array}{l}\text { Hialina, espessura } \\
\text { uniforme }\end{array}$ & $\begin{array}{l}\text { Margens } \\
\text { arredondadas }\end{array}$ \\
\hline 2 & $\begin{array}{l}\text { Tecido fibroso na } \\
\text { periferia }\end{array}$ & $\begin{array}{l}\text { Material mucinoso } \\
\text { entre as lamelas }\end{array}$ & Espessura irregular & Margem afiladas \\
\hline 3 & $\begin{array}{ll}\text { Tecido } & \text { fibroso } \\
\text { consolidado } & \end{array}$ & $\begin{array}{l}\text { Infiltração mucinosa } \\
\text { extensa; perda da } \\
\text { distinção anel-núcleo }\end{array}$ & $\begin{array}{l}\text { Defeitos focais na } \\
\text { cartilagem }\end{array}$ & $\begin{array}{l}\text { Condrófitos ou } \\
\text { osteófitos precoces } \\
\text { nas margens }\end{array}$ \\
\hline 4 & $\begin{array}{l}\text { Fendas horizontais } \\
\text { paralelas à placa } \\
\text { vertebral }\end{array}$ & Disrupções focais & $\begin{array}{l}\begin{array}{l}\text { Fibrocartilagem } \\
\text { estendendo-se do } \\
\text { osso subcondral; }\end{array} \\
\text { Irregularidade } \\
\text { esclerose focal no } \\
\text { osso subcondral }\end{array}$ & Osteófitos $<2 \mathrm{~mm}$ \\
\hline 5 & $\begin{array}{l}\text { Fendas estendem-se } \\
\text { através do núcleo e } \\
\text { anel }\end{array}$ & & Esclerose difusa & Osteófitos > $2 \mathrm{~mm}$ \\
\hline
\end{tabular}

FONTE: Adaptado de Thompson et al., 1990 221 . 


\subsection{Microscopia de luz}

Todos os discos C4C5, C5C6, L4L5 e L5S1 de de GJ e Gl foram submetidos à análise por microscopia de luz. Para esta e todas as avaliações subsequentes, os discos foram divididos em diferentes fragmentos discais contendo também a placa vertebral adjacente. Considerando-se a dificuldade em se distinguir o complexo anel-núcleo em discos do segmento cervical na idade adulta sob análise macroscópica ${ }^{189}$, estes foram divididos somente em dois fragmentos: anterior e posterior. Já os discos do segmento lombar foram separados em três fragmentos: dois anulares, anterior e posterior, e um terceiro fragmento contendo a região central do disco intervertebral. Assim, obteve-se de cada indivíduo de cada grupo 10 fragmentos: 4 cervicais ( $44 \mathrm{C} 5$ e C5C6, anterior e posterior cada) e 6 lombares (L4L5 e L5S1, anterior, central e posterior).

Dez cadáveres de cada grupo (미 e $\underline{\mathbf{G I}}$ ) foram seccionados no plano sagital e cinco no plano coronal. Após inclusão em meio de congelamento (Jung Tissue Freezing Medium, Leica Microsystems, Wetzlar, Alemanha), secções de 8 micrômetros de espessura foram realizadas em criostato (CM1850, Leica Microsystems) e coradas conforme técnicas histológicas de rotina: hematoxilina e eosina (HE) para organização geral, hematoxilina férrica de Verhoeff para fibras elásticas ${ }^{222}$, resorcina-fucsina de Weigert para elásticas e elaunínicas ${ }^{223,224}$ e Picro-Sirius sob luz normal e polarizada para estudo de fibras colágenas ${ }^{76,225}$. A identificação de fibras oxitalânicas através de oxidação prévia à coloração de Weigert foi testada em um piloto com dois cadáveres de cada grupo ${ }^{226}$. Com a constatação de ausência de diferença em relação à coloração por Weigert convencional, sem oxidação, esta etapa foi abandonada. Após a coloração, estas lâminas foram submetidas à desidratação em série crescente de etanol e xilol e montadas com Entellan (Merck KgaA, Darmstadt, Alemanha) e lamínula. A análise foi realizada em em microscópio convencional com sistema de aquisição de imagem (Axioskop40, CarlZeiss GmbH, Gottingen, Alemanha) e filtro de polarização no caso de PicroSirius ${ }^{224}$. 


\subsection{Microscopia eletrônica de varredura}

Os discos cervicais e lombares de três indivíduos de cada grupo foram selecionados para análise por MEV. Após descalcificação e preparo dos fragmentos descritos previamente, os mesmos foram montados em bases para criostato com orientação sagital (dois cadáveres de cada grupo) ou coronal (um espécime). No criostato, foi realizado o desbaste destes blocos até o ponto médio do espécime, formando assim uma superfície de corte para análise por microscopia eletrônica conforme Fontes et al. ${ }^{227}$. Estes fragmentos foram removidos de suas bases de criostato e reposicionados em bases metálicas próprias para MEV, desidratados em estufa a $45^{\circ} \mathrm{C}$ por 12 horas, recobertos com ouro (Balzers Union SCD-040, Liechtenstein), analisados e fotografados em microscópio eletrônico de varredura (Leo 435 VP, Cambridge, Reino Unido) ${ }^{227}$.

\subsection{Imuno-histoquímica (IHC)}

Para esta metodologia, três cadáveres de cada grupo foram pré-selecionados. O protocolo de IHC foi aqui adaptado a partir de Nerlich et al., Hu et al. e informações técnicas de dois fabricantes de anticorpos $52,58,239$. Todas as etapas foram padronizadas em experimentos pilotos perfazendo mais de 200 lâminas e 400 cortes que foram ulteriormente excluídos da análise. Os discos foram inicialmente preparados como no item 3.4, tendo sido obtidas secções de cada setor discal de 8 micrômetros de espessura.

Todos os experimentos foram agrupados por anticorpo primário, impedindo assim a contaminação cruzada de tipos diferentes de colágeno. Dois controles negativos foram realizados por indivíduo e anticorpo: um controle duplo-negativo (sem anticorpo primário ou secundário) e um controle simples-negativo (apenas sem anticorpo primário). Desta maneira, não apenas se controla o experimento para marcação de fundo (ou background) 
mas também se entende a natureza desta marcação anômala: no controle duplo-negativo, investiga-se fatores inespecíficos de marcação (por exemplo, presença de peroxidase endógena ou superexposição ao cromógeno) enquanto que o controle simples negativo investiga marcação inespecífica pelo anticorpo secundário (que seria a mais semelhante à marcação real pelo anticorpo primário). Estas etapas foram assim desenvolvidas com vistas à quantificação da marcação (item 3.7). Infelizmente, não há como produzir um controle positivo satisfatório - meramente verificar a marcação de determinado tipo de colágeno em outro tecido, ainda que da mesma espécie, apenas confirma as informações fornecidas do fabricante. Por se tratar de material raro, humano e fixado de maneira única, não se encontram controles na literatura facilmente; o mais próximo é a série de trabalhos de Nerlich et al., sobre os quais se faz a discussão ${ }^{56,96}$.

Quanto aos anticorpos primários selecionados, estes basearam-se nos tipos de colágenos mais estudados na literatura para o disco intervertebral, em grande parte devido aos trabalhos do grupo de Munique liderado pelo Prof. Nerlich ${ }^{56,86,83,228,88}$. Além disso, estes necessitavam estar disponíveis no mercado, possuírem especificidade para colágeno humano e terem sido criados em uma única espécie, de modo a permitir a utilização de apenas um tipo de anticorpo secundário. Todos os colágenos considerados relevantes para esta pesquisa preencheram os critérios supra-citados, e detalhes dos anticorpos utilizados encontram-se no Quadro 2 (Fabricantes: Abcam, Cambridge, Reino Unido; Santa Cruz Biotechnology, Santa Cruz, Estados Unidos; Sigma-Aldrich, Saint Louis, Estados Unidos e Millipore, Billerica, Estados Unidos). Seguindo a classificação de Ricard-Blum, estes colágenos são divididos de acordo com seus arranjos supramoleculares ${ }^{229}$ : foram estudados quatro colágenos fibrilares (I, II, III e V), dois colágenos formadores de redes (colágeno IV e $\mathrm{X}$ ), um colágeno formador de fibrilas rombas (beaded fibrils - colágeno VI) e um colágeno associado a fibrilas (FACIT - fibril-associated collagen with interrupted triple helices colágeno IX). Todos os anticorpos primários são nativos de ratos, e foi utilizado um sistema de imuno-histoquímica baseado em cromógeno com anticorpo secundário de cabra (ImmunoCruz staining system - sc-2017 - SantaCruz Biotechnology). 
Os cortes foram inicialmente lavados com solução-tampão fosfato (PBS) e incubados com protease por 30 minutos a $37^{\circ} \mathrm{C}$ para desmascaramento antigênico, uma vez que os espécimes haviam sido fixados em formaldeído. As proteases escolhidas foram tripsina $0,2 \%$ para colágeno I e pepsina $0,4 \%$ em $\mathrm{HCl} 0,01 \mathrm{~N}$ para todos os outros colágenos (SigmaAldrich $)^{56}$. Seguiram-se nova lavagem em água deionizada, incubação em $\mathrm{H}_{2} \mathrm{O}_{2}$ por cinco minutos e duas lavagens em PBS. As amostras foram incubadas com o anticorpo primário por 12 horas a $4^{\circ} \mathrm{C}$, seguida por três lavagens em PBS e nova incubação com o anticorpo secundário conjugado a biotin por 30 minutos a $37^{\circ} \mathrm{C}$. Três novas lavagens com PBS foram realizadas e o conjugado $A B$ (avidin e peroxidase) adicionado por 30 minutos, à temperatura ambiente. Mais duas lavagens com PBS e, por fim, os cortes foram submetidos à reação com cromógeno (diaminobenzidina - DAB) por 3 minutos, lavados em água deionizada, submetidos à desidratação em série crescente de álcoois e montados conforme mencionado $\operatorname{acima}^{240,241}$.

Quadro 2 - Anticorpos primários utilizados no estudo.

\begin{tabular}{ccc}
\hline Antígeno & Fabricante & Código \\
\hline Colágeno I & Abcam & ab90395 \\
Colágeno II & Santa Cruz & sc-59958 \\
Colágeno III & Sigma-Aldrich & C7805 \\
Colágeno IV & Sigma-Aldrich & C1926 \\
Colágeno V & Millipore & MAB3393 \\
Colágeno VI & Santa Cruz & sc-47712 \\
Colágeno IX & Millipore & MAB3304 \\
Colágeno X & Sigma-Aldrich & C7574 \\
\hline
\end{tabular}




\subsection{Quantificação da marcação imuno-histoquímica}

De modo a evitar os problemas inerentes da avaliação qualitativa mencionados na Introdução, foi padronizada uma maneira de quantificar a marcação proporcionada pelo cromógeno no estudo imuno-histoquímico. Além da avaliação qualitativa, como utilizada por Nerlich et al., uma avaliação quantitativa de marcação proporcionada por anticorpo só foi tentada no disco intervertebral para fatores neurotróficos por Purmessur et al. ${ }^{123}$, através de contagem de células marcadas e não-marcadas. Infelizmente, além de estes autores não empregarem métodos estereológicos adequados para assegurar a homogeneidade dos resultados ao longo de todo o espécime, tal método aplicaria-se apenas a antígenos intracelulares e não proteínas estruturais, como o caso do colágeno.

Excluindo-se a simples contagem de células marcadas e não-marcadas, há basicamente dois métodos para quantificação de marcação imuno-histoquímica. Ambos são derivados do avanço da informática em termos de programas de análise de imagens e da tecnologia digital de aquisição das mesmas. O primeiro método é a quantificação da intensidade de marcação. Desenvolvido por Mosedale et al., este método parte da decomposição de determinada cor em três canais de cores RGB (red, green e blue - vermelho, verde e azul), transformação em tons de cinza e subsequente contabilização por programa de análise de imagem: quanto mais escura, maior a marcação ${ }^{230,231}$. Entretanto, a relação anticorpoantígeno não é estequiométrica, a não ser em graus muito baixos de marcação, e os sistemas avidina-biotina frequentemente amplificam o sinal da marcação de 7 a até 200 vezes para permitir maior sensibilidade ${ }^{232,233}$. Assim, embora de condução extremamente fácil, este método é de alguma utilidade apenas para marcações por fluorescência e numa intensidade muito baixa. No presente material, realizou-se estudos-piloto que permitiram verificar que a quantidade de autofluorescência inviabiliza qualquer tentativa de quantificação, pois o colágeno é uma das proteínas com maior autofluorescência do corpo humano, inclusive com aplicações clínicas em neurocirurgia, e a fixação por qualquer aldeído aumenta ainda mais esta fluorescência ${ }^{234,235}$. 
O segundo método baseia-se na quantidade de área marcada, e foi primeiramente reportado por Lehr et al. ${ }^{231}$. Com este método, após a decomposição da cor em três canais e transformação para tons de cinza, o número de pixels marcados em determinado corte é comparado com o valor total, gerando uma porcentagem de área marcada que, com o auxílio de uma escala, pode ser transformada em um valor absoluto. Há duas desvantagens neste método: uma desvantagem inerente, pois cada pixel precisa ser definido como "positivo" ou "negativo" para efeitos de contabilização, perdendo assim discretas nuances de intensidade de marcação em níveis baixos e outra, potencial, pois ainda depende de um comando de operador para definição, em cada imagem, a partir de que nível de cinza um determinado pixel é considerado positivo ${ }^{231,233,236}$. Todas as tentativas para corrigir a necessidade de um comando humano, por outro lado, esbarram na questão da amplificação do sinal, como o método de Matkowskyj et al. para quantificar a "energia" de marcação ${ }^{236}$.

Assim, optou-se por um método baseado em área como o mais adequado ao presente estudo $^{231}$. Após preparo das lâminas conforme descrito acima, 10 campos microscópicos foram adquiridos em microscópio convencional de bancada com sistema digital de aquisição de imagem, sob objetiva de 100x (Axioskop40 e Axiovision 6.3, CarlZeiss). Gerado um arquivo de alta resolução .TIF, esta imagem foi transferida para um computador pessoal e analisada no programa ImageJ 1.44 (National Institutes of Health, Estados Unidos, disponível em http://rsbweb.nih.gov/ij/) $)^{237}$. Decomposta a imagem em três canais de cor RGB, foi escolhido o canal com maior distinção entre a marcação e o fundo/artefato, gerando assim uma imagem em tons de cinza. Na sequência, foi estabelecido o valor mínimo (threshold) para marcação positiva e o programa retorna um valor em termos de percentual de área marcada. Dez campos foram registrados e contabilizados por lâmina; considerando-se os discos foram considerados por segmento (cervical ou lombar apenas, sem distinção entre C4C5 e C5C6, por exemplo), gerou-se assim um elevado número de medidas por setor discal e antígeno (Tabela 2). Foram ainda fotografados e avaliados controles duplo-negativo e simples-negativo por cadáver de modo a contabilizar também o artefato de fundo gerado pelo sistema $A B C$ (controle duplo-negativo) e por eventual marcação inespecífica do 
anticorpo secundário (controle simples-negativo). O exemplo gráfico do protocolo de análise de imagem é encontrado na Figura 5.

Tabela 2 - Resumo do procedimento de contabilização da marcação por área, tomando-se um setor discal e anticorpo por exemplo.

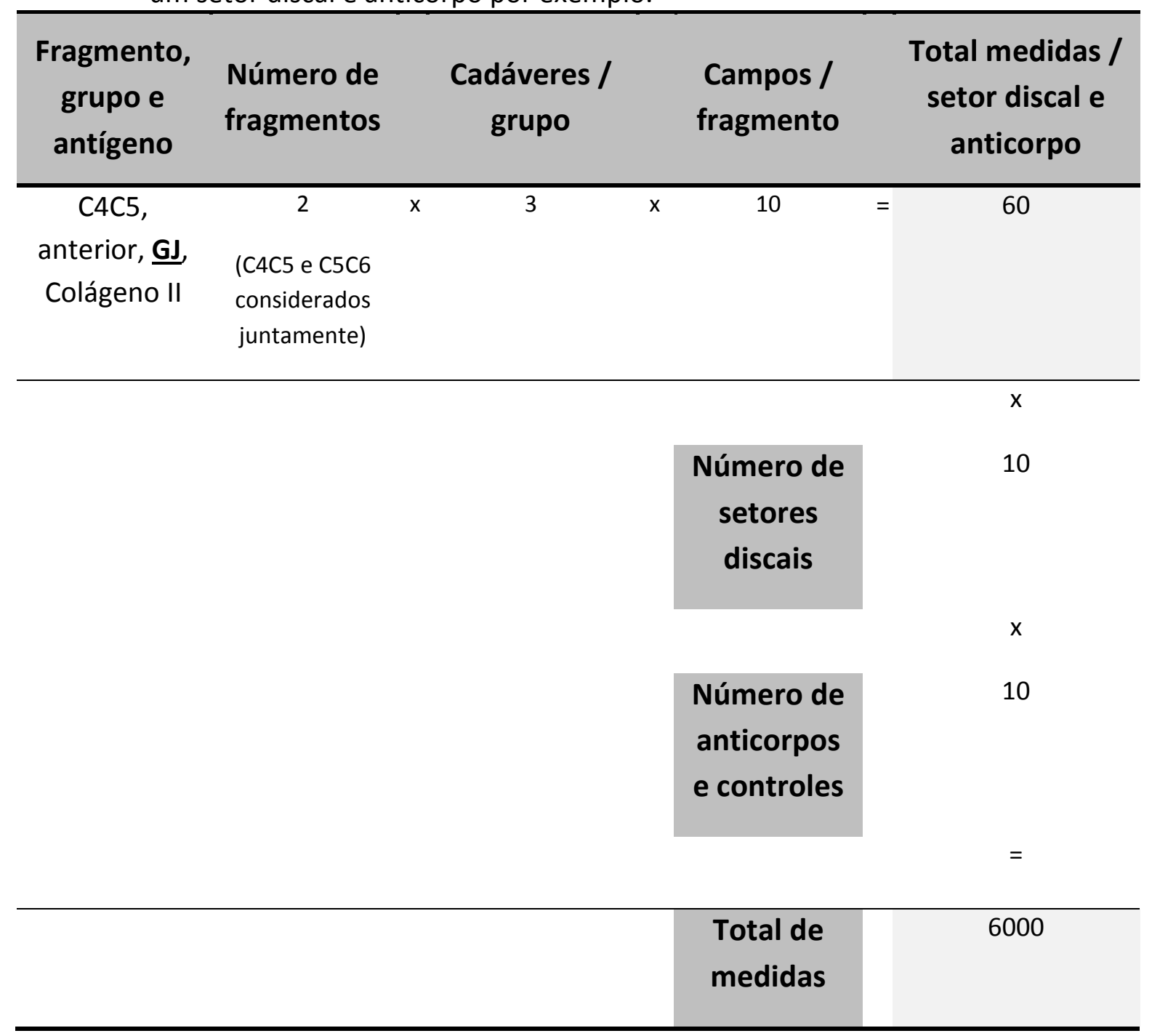




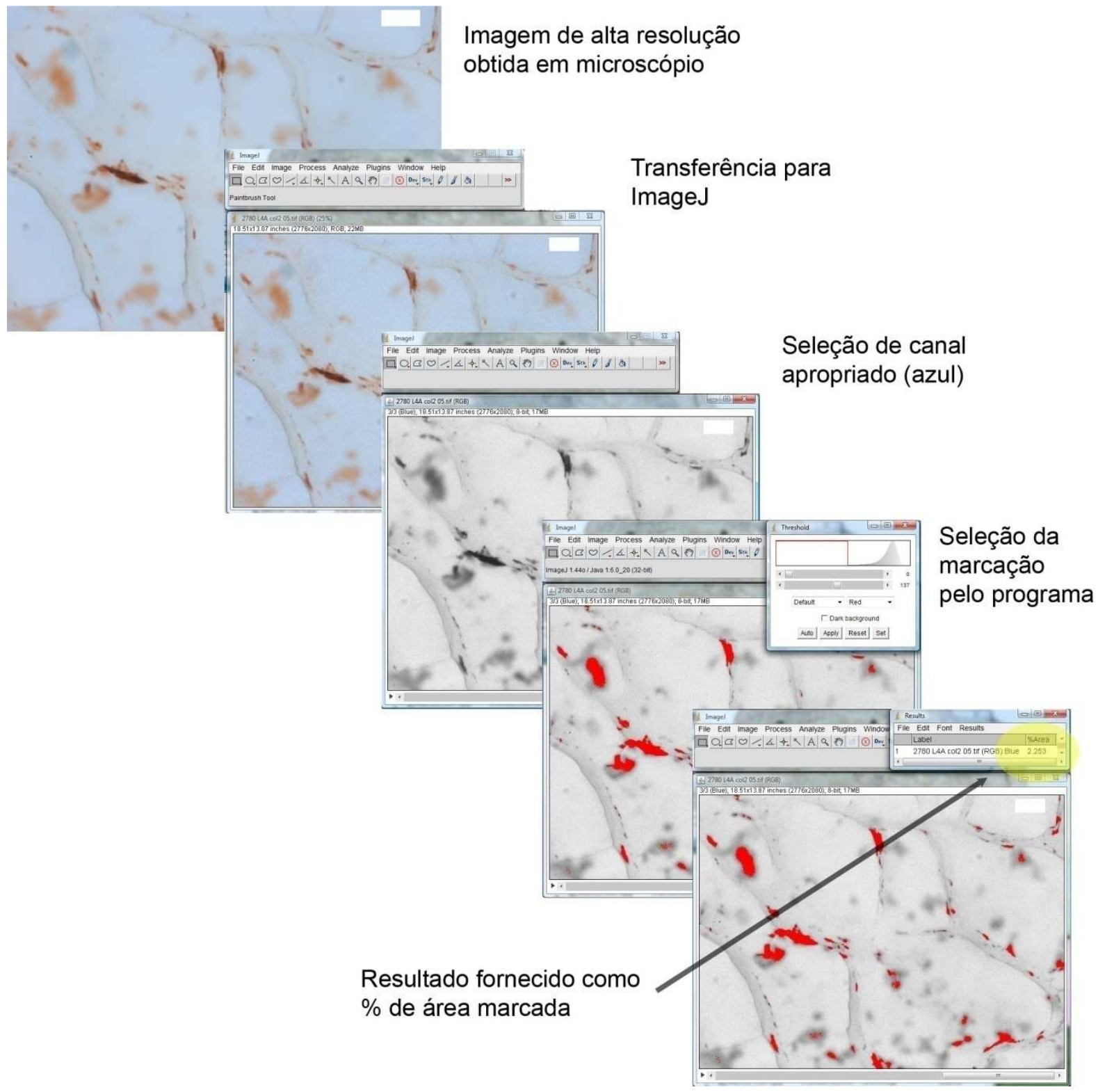

Figura 5 - Representação da análise gráfica no programa ImageJ. 


\subsection{Tratamento estatístico}

As variáveis submetidas a tratamento estatístico foram: idade, parâmetros antropométricos, graduação de Thompson e porcentagem de área marcada pela imuno-histoquímica. Todas estas variáveis exceto a graduação de Thompson são de natureza contínua e, presume-se, distribuição Gaussiana. Devido à presença de valores extremos na contabilização da marcação imuno-histoquímica, avaliação da normalidade com o teste de D'Agostino-Pearson ocasionalmente sugere que a distribuição de alguns grupos fragmento-anticorpo não seria Gaussiana. Estes casos foram apenas exceções; além disso, pelo grande número de amostras envolvidas, eventual distribuição não-Gaussiana não seria problema para testes paramétricos como teste $T$ de Student ou ANOVA (Analysis of Variance). Sendo assim, decidiu-se, ao invés de excluir diversos eventuais valores extremos, adotar testes paramétricos para as variáveis contínuas resultando assim em maior rigor científico ${ }^{238}$.

Todas as análises foram conduzidas mantendo o nível de significância de 0,05238. Para análises simples envolvendo apenas dois grupos (idade, parâmetros antropométricos e análise da área marcada quando comparando $\underline{\mathbf{G J}}$ versus $\underline{\mathbf{G I}}$ ou entre segmentos) foi utilizado o teste $T$ de Student. Para análise da significância da marcação (tipo colágeno versus controle negativo versus controle duplo-negativo) foi utilizado ANOVA como teste paramétrico ideal seguido, em caso de diferença significativa, do teste de Tukey para localizar a diferença entre os grupos ${ }^{238}$. Somente foi considerada a significância no teste post-hoc. Por se tratar de variável ordinal, no caso da graduação de Thompson foi utilizado o teste de Mann-Whitney com os demais parâmetros mantidos conforme supracitado ${ }^{238}$.

Os anexos $\underline{\mathbf{A}}$ e $\underline{\mathbf{B}}$ contém um resumo da alocação dos cadáveres pelos diferentes experimentos bem como o cálculo do total de lâminas preparadas neste estudo. 
4 Resultados 


\subsection{Ressonância Magnética}

A aquisição de imagens de ressonância magnética dos 10 indivíduos permitiu visualizar os discos tanto no segmento cervical quanto lombar de maneira satisfatória em ambos os grupos (Figuras $6, \underline{7}$ e $\underline{8}$ ). O grau de detalhe que se obteve foi semelhante àquele do ambiente clínico ao se avaliar um exame de RM na sequência T2. Além disso, a RM demonstrou sensibilidade suficiente para detectar inclusive pequenos detalhes morfológicos, como a distinção anel-núcleo ou a presença de pequenas fissuras horizontais. A Figura $\mathbf{6}$ demonstra um exemplo típico de $\underline{\mathbf{G J}}$, onde, apesar de aparentemente o grau de degeneração ser pequeno, com altura mantida e ausência de osteófitos, um exame mais preciso revela, no segmento lombar, a perda da distinção anel-núcleo em L4L5 e uma fissura horizontal em L5S1. Já a Figura 7 demonstra excelente exemplo de discrepância entre as dois segmentos: em seu bloco cervical, as fissuras horizontais de C4C5 foram claramente demonstradas na RM, estendendo-se através do núcleo e parte posterior do anel fibroso. Este dado, em conjunto com os osteófitos / condrófitos maiores que $2 \mathrm{~mm}$, são características de uma classificação Thompson 5. Por outro lado, os discos lombares apresentam-se relativamente preservados, inclusive mantendo certa distinção entre anel e núcleo (iguras 7B e $\underline{7 D}$ ). Um exemplar de $\underline{\text { GI }}$ que demonstra o grau 5 de Thompson em todos os seus discos está demonstrado na Figura 8. 0 indivíduo 4411 exibe em 3 dos 4 discos estudados colapso estrutural, osteófitos e fissuras horizontais especialmente evidentes no segmento lombar. 

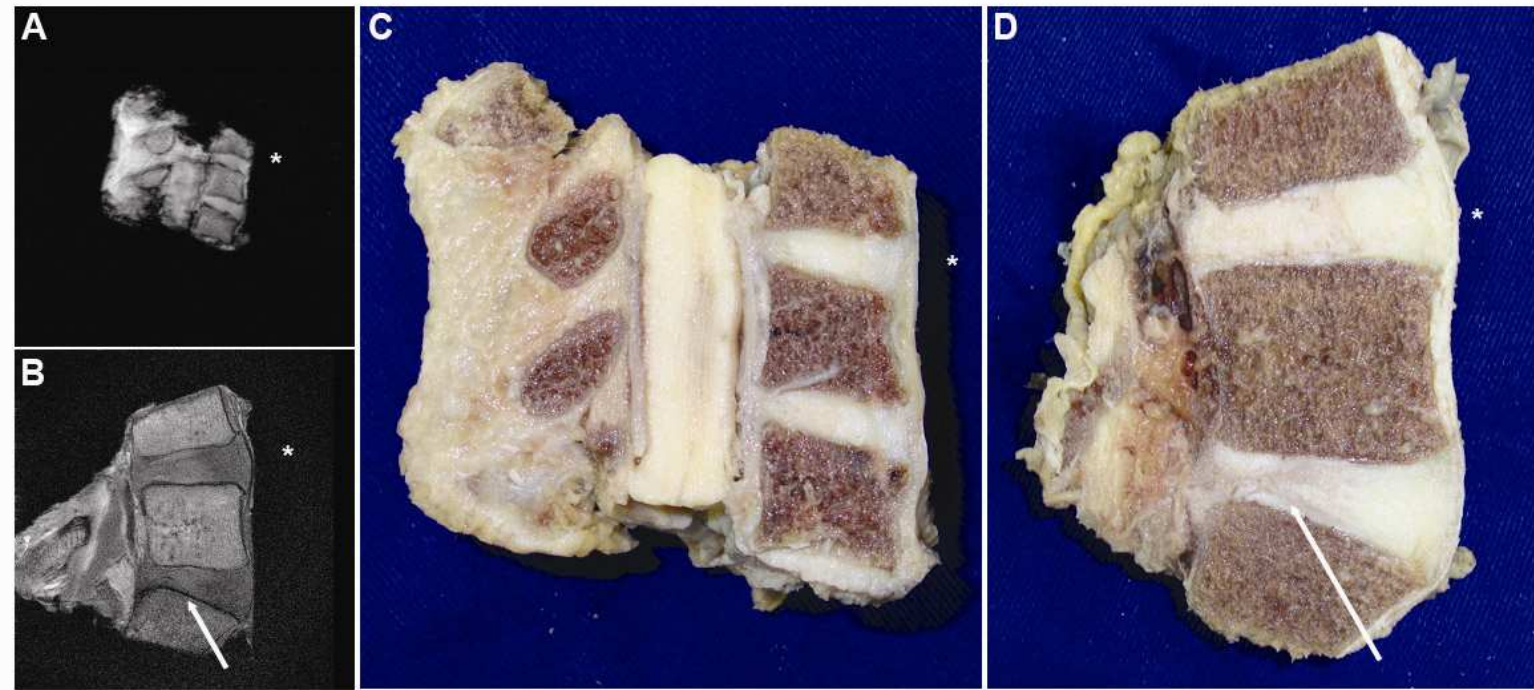

Figura 6 - Comparação das imagens de RM do cadáver 4410 (G) $)$ com a macroscopia. Espécime com altura discal e aspecto inicial relativamente preservado; entretanto, a perda de distinção anel-núcleo em L4L5 e a presença de uma fissura horizontal através da parte posterior do anel fibroso de L5S1 resultam em graduações 3 e 4 de Thompson (seta branca), respectivamente. A RM forneceu uma avaliação muito próxima da macroscopia, inclusive demonstrando a fissura horizontal em L5S1. Asteriscos demonstram os discos mais rostrais

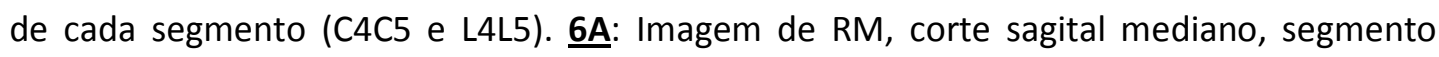
cervical e $\underline{6 \mathrm{~B}}$ : lombar. $\underline{\mathbf{6 C}}$ : peça anatômica, segmento cervical e $\underline{\text { GD: }}$ lombar.
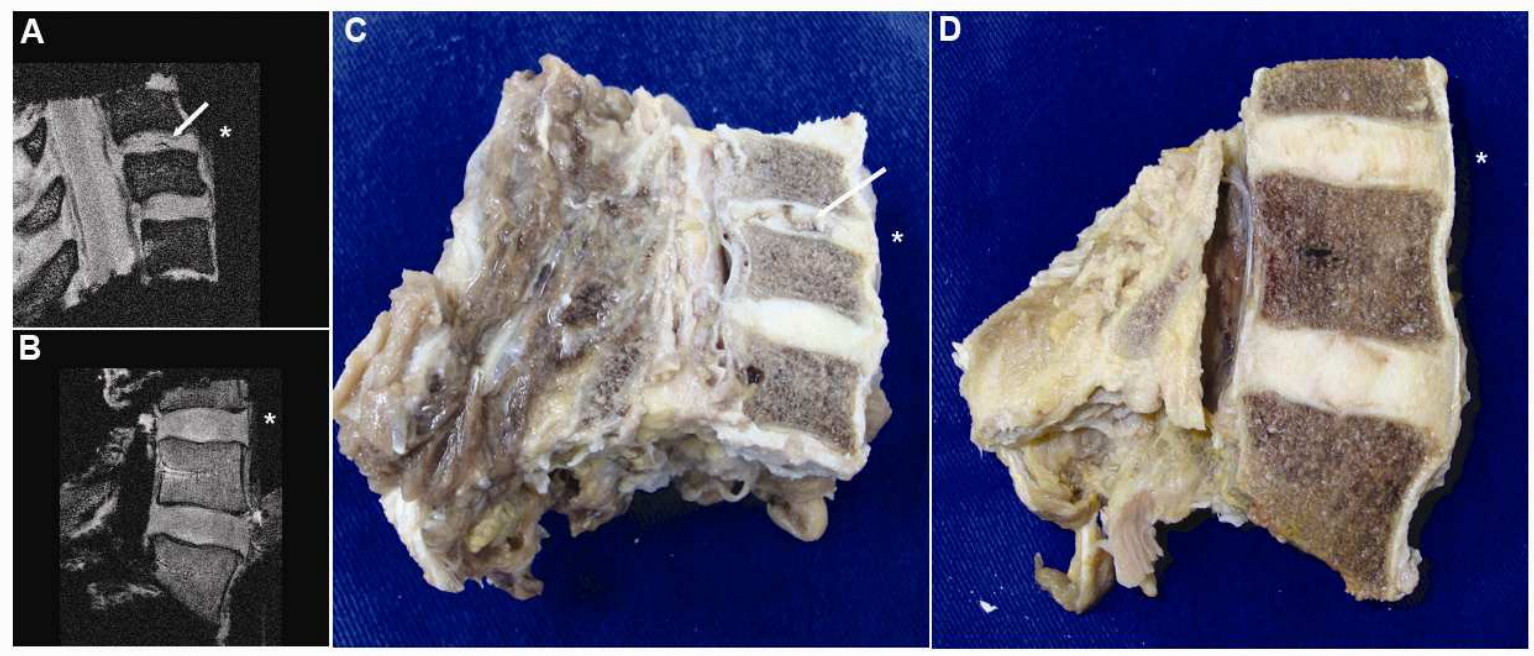

Figura 7 - Comparação das imagens de RM do cadáver 4413 ( $\underline{\text { GJ }})$ com a macroscopia, onde fica evidente o grau distinto de degeneração entre os segmentos cervical ( $\underline{\mathbf{A}}$ e $\underline{\mathbf{C}})$ e lombar ( $\underline{\mathbf{B}}$ e D). Os discos cervicais apresentam degeneração avançada, com fissuras horizontais através do disco C4C5 estendendo-se através de núcleo e anel posterior (seta branca), adequadamente visualizada pela RM. Os discos C4C5 receberam graduação 5 e 4, respectivamente; já ambos os discos lombares receberam graduação 2 , já que há alguma distinção entre anel e núcleo. Asterisco indica os discos rostrais de cada segmento (C4C5 e L4L5). $\underline{\text { ZA: }}$ Imagem de RM, corte sagital mediano, segmento cervical e $\underline{\mathbf{7 B}}$ : lombar. $\underline{\mathbf{7 C}}$ : peça anatômica, segmento cervical e $\underline{7 D}$ : lombar. 

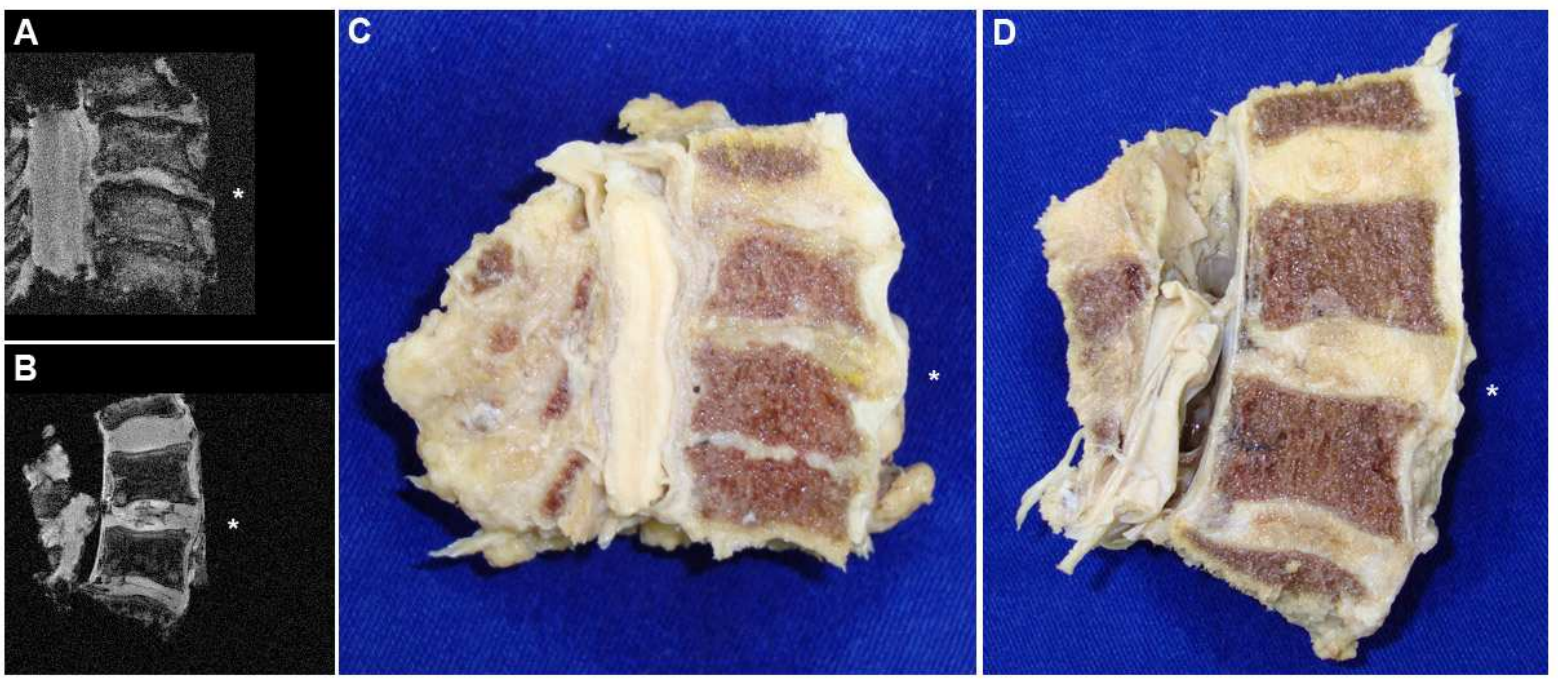

Figura 8 - Comparação das imagens de RM do cadáver 4411 (GI) com a macroscopia. Aqui fica claro o grau extremo de degeneração: os discos C4C5 e C5C6 estão completamente anquilosados, além de exibirem osteófitos maiores que $2 \mathrm{~mm}(\underline{\mathbf{8 A}}$ e $\underline{\mathbf{8 C}})$. O mesmo ocorre para L5S1; ainda que L4L5 não tenha sofrido colapso estrutural, fissuras horizontais estendendo-se através do disco inteiro são evidentes tanto em L4L5 como L5S1, na RM (므) e na macroscopia (므). O asterisco indica os discos C4C5 e L4L5; este é um exemplo em que a remoção dos blocos levou um disco adjacente. 7A: Imagem de RM, corte sagital mediano, segmento cervical e 7B: lombar. 7C: peça anatômica, segmento cervical e 7D: lombar.

\subsection{Avaliação macroscópica}

Todos os 30 cadáveres foram classificados satisfatoriamente segundo a gradação de Thompson; os resultados encontram-se na Tabela $\mathbf{3}$. Todos os graus de Thompson foram demonstrados nesta amostra (Figuras $9, \underline{10}$ e $\underline{11}$ ). Assim, poucos foram os discos que receberam a graduação 1 no nível cervical em $\underline{\mathbf{G}}$, ainda que compusessem um quinto dos discos lombares (2/30 e 6/30, segmentos cervical e lombar respectivamente). Os discos grau 1 não foram encontrados em $\underline{\text { GI }}$ e até mesmo os discos com graduação 2 foram relativamente raros $(3 / 30$ e 4/30). Todos os elementos degenerativos citados na classificação de Thompson foram identificados: colabamento discal, perda de distinção anelnúcleo, esclerose focal e difusa e fendas horizontais (Figuras $\mathbf{9}, \underline{10}$ e $\underline{11}$ ). 


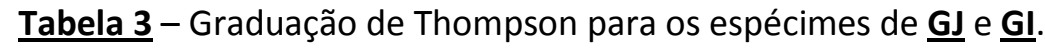

\begin{tabular}{lllll}
\hline & \multicolumn{5}{c}{ Disco } \\
\cline { 2 - 5 } Espécime & C4C5 & C5C6 & L4L5 & L5S1 \\
\hline
\end{tabular}

$\underline{G J}$

$300 / 08$
$314 / 08$
$479 / 08$
$2780 / 08$
$2781 / 08$
$2788 / 08$
$6040 / 08$
$9386 / 08$
$11243 / 08$
$11250 / 08$
$1767 / 09$
$4410 / 09$
$4413 / 09$
$5050 / 09$
$5091 / 09$

Média +/-DP

$2,93+/-0,96 \quad 2,67+/-1,05$

$2,53+/-1,06$

$2,67+/-1,11$

Média segmento +/-DP

$2,80+/-1,00$

$2,6+/-1,07$

$\underline{G l}$

$320 / 08$
$321 / 08$
$323 / 08$
$478 / 08$
$482 / 08$
$2786 / 08$
$2787 / 08$
$2789 / 08$
$2790 / 08$
$5981 / 08$
$6042 / 08$
$8354 / 08$
$8356 / 08$
$8358 / 08$
$4411 / 09$

$320 / 08$

$321 / 08$

$323 / 08$

$482 / 08$

$2786 / 08$

$2787 / 08$

$2790 / 08$

$5981 / 08$

$6042 / 08$

$8354 / 08$

$8358 / 08$

$4411 / 09$

Média +/-DP

$4,20+/-1,08$

$4,27+/-1,03$

$3,93+/-1,22$

$3,93+/-1,03$ 

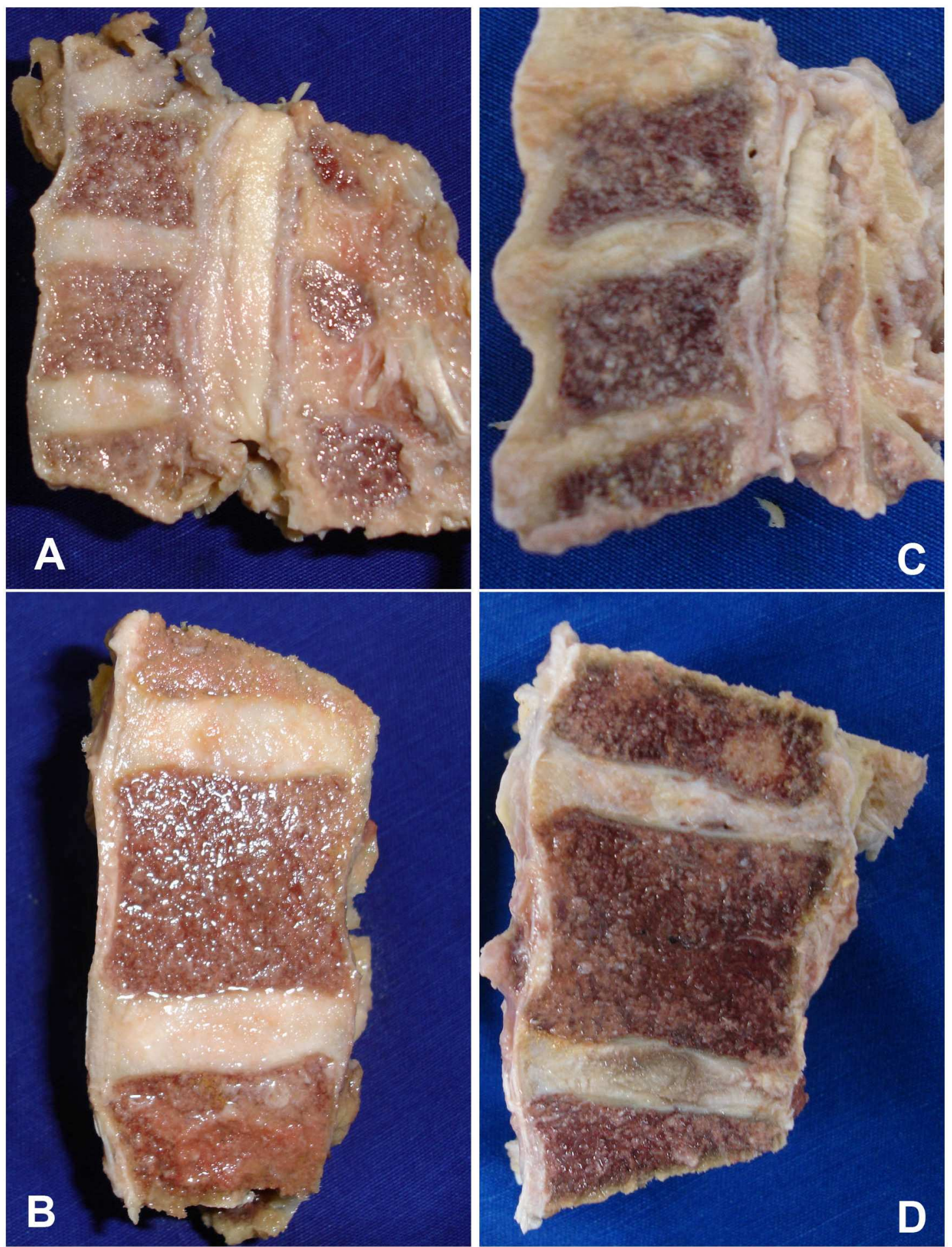

Figura $\mathbf{9}$ - Espécimes cervicais $(\underline{\mathbf{A}, \mathbf{C}})$ e lombares $(\underline{\mathbf{B}, \mathbf{D}})$ seccionados no plano sagital mediano para avaliação segundo Thompson. Os espécimes $6040(\underline{\mathbf{A}, \mathbf{B}})$ e $6042(\underline{\mathbf{C}, \mathbf{D}})$ apresentaram os resultados mais discrepantes na avaliação morfológica (Tabela $\mathbf{3}$ ), 6040 possuindo apenas perda da distinção anel-núcleo em C4C5 (Thompson 2) e o restante recebendo grau 1. Já o espécime 6042 exibiu o total colapso discal. 


\section{Grupo}

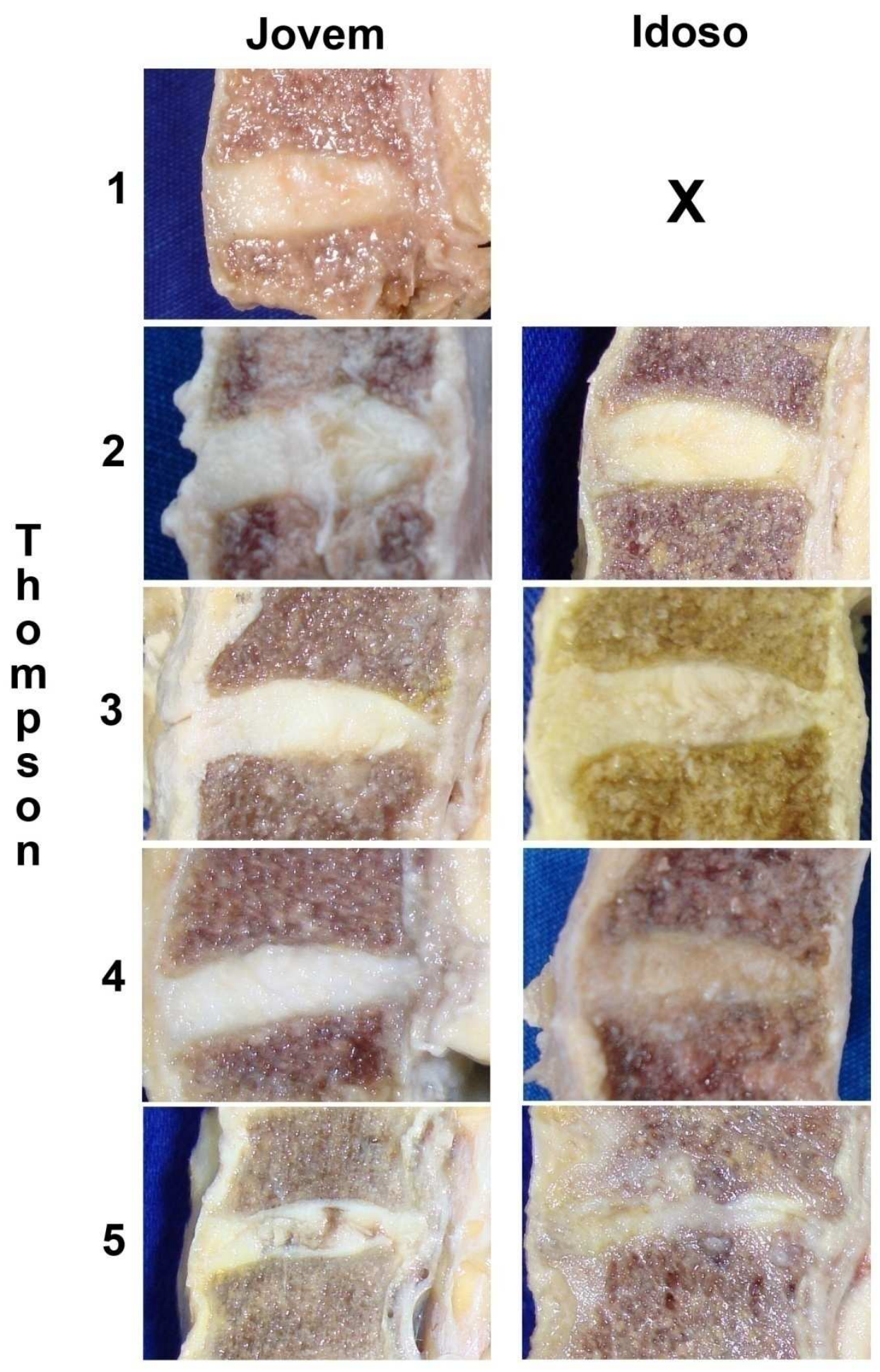

Figura 10 - Segmento cervical - demonstração dos diferentes graus de Thompson em G] e Gl. Não foram encontrados discos Thompson 1 no Grupo Idoso. 


\section{Grupo}

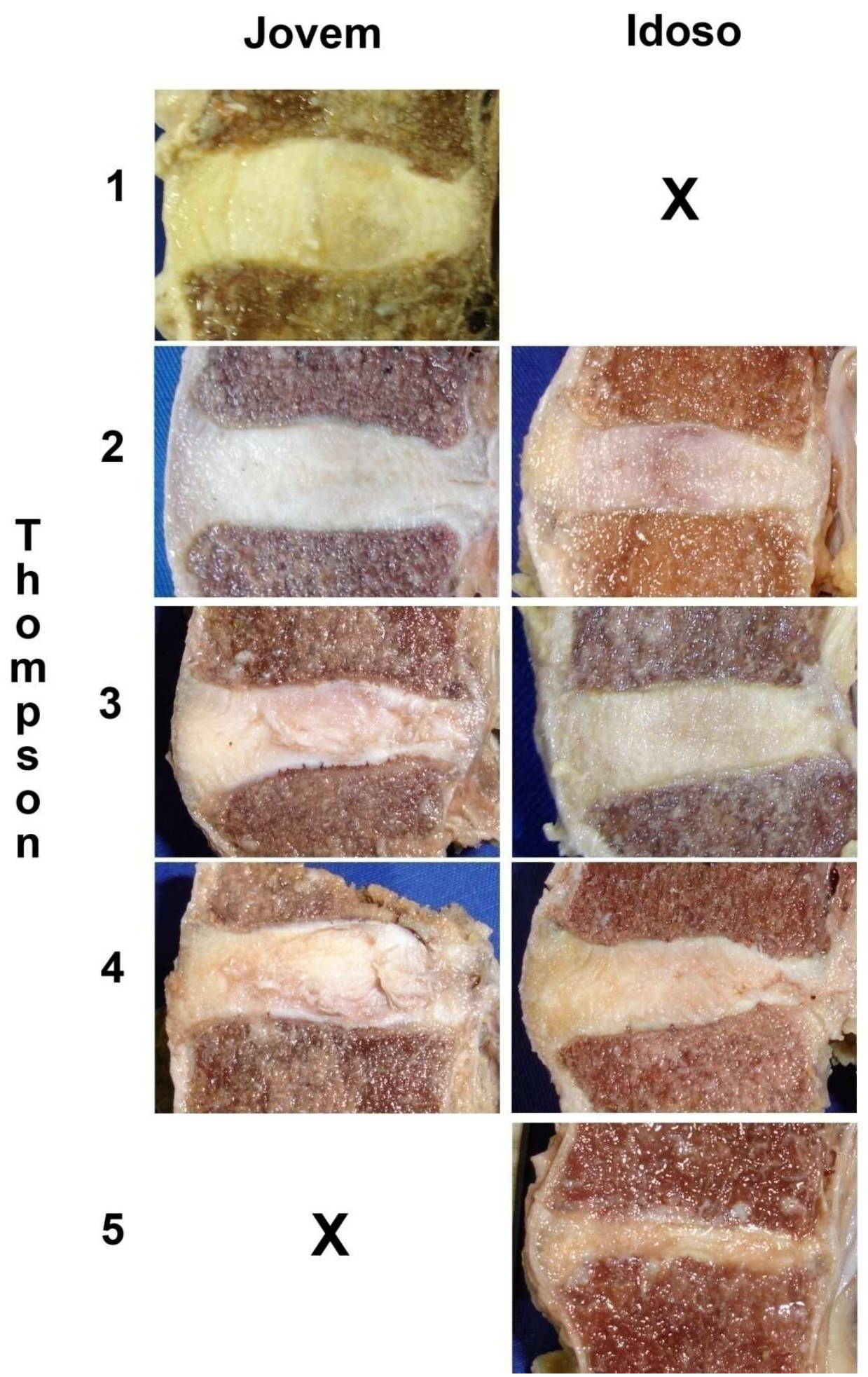

Figura 11 - Segmento lombar - demonstração dos diferentes graus de Thompson em GJ e GI. Não foram encontrados discos Thompson 1 no Grupo Idoso ou Thompson 5 no Grupo Jovem. 
Ainda que discos com colapso estrutural completo fossem raros nos jovens (Thompson 5: 1/30 discos cervicais), algum grau de degeneração foi a norma e até graus avançados foram comuns: exatamente $25 \%$ dos discos de $\underline{\mathbf{G J}}$ de ambos os segmentos já apresentavam sinais avançados de degeneração (graduação 4 de Thompson). No grupo idoso, percebeu-se claramente o efeito etário, pois a classificação 5 de Thompson não só foi encontrada com frequência como foi recebida por mais de $50 \%$ dos discos do segmento cervical de $\mathbf{G I}$ (16/30 e 12/30, GI cervical e lombar, respectivamente). A variação de graduações dentro de um mesmo indivíduo também era esperada e não foi infrequente, verificando-se que 4/15 cadáveres de GJ e 7/15 de $\underline{\text { Gl }}$ apresentaram variações de 2 graus de Thompson. Variações mais extremas, como 3 graus de Thompson, foram raras (apenas um cadáver de $\underline{\text { GJ) bem }}$ como variações de 2 graus dentro de um mesmo segmento (também apenas um cadáver de GJ - espécime 4413, demonstrado na Figura 7). Percebe-se assim que homogeneidade de resultados dentro de um mesmo segmento é a norma desta população, embora frequentemente um segmento esteja mais degenerado que o outro (Tabela $\mathbf{3}$ ).

As análises estatísticas dentro de determinado segmento (por exemplo, C4C5 versus C5C6) não mostraram diferenças em nenhum dos grupos ( $p=0,572$ e 0,731, para GJ e $p=0,836$ e 0,844 para Gl, cervical e lombar respectivamente). Assim, as principais comparações foram feitas agrupando-se os discos de cada segmento dentro de um único grupo. A diferença entre $\underline{\mathbf{G J}}$ e GI foi estatisticamente significante e está demonstrada na Figura 12. Os 45 anos que, em média, separam os cadáveres de $\underline{\mathbf{G I}}$ dos cadáveres de $\underline{\mathbf{G}}$ foram responsáveis por adicionar cerca de 1,4 e 1,3 pontos de degeneração para os segmentos cervical e lombar, respectivamente (Tabela $\mathbf{3})$. 

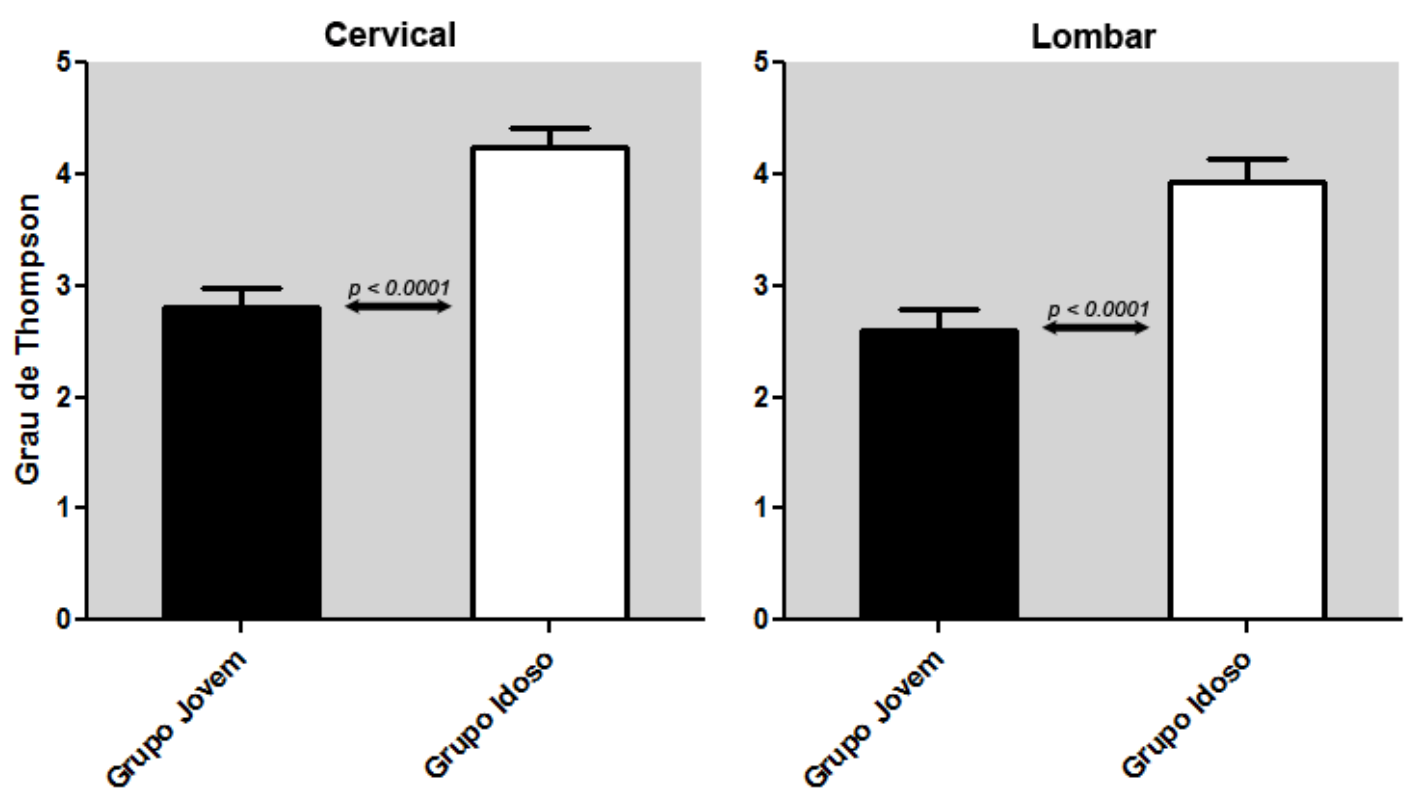

Figura 12 - Graduações conforme Thompson para os discos dos segmentos cervical e lombar. Os discos de $\underline{\mathbf{G l}}$ são significativamente mais degenerados que aqueles de $\underline{\mathbf{G J}}$, em ambos os segmentos (desvio-padrão encontra-se assinalado em cada coluna).

\subsection{Microscopia de Luz}

Os métodos selecionados provaram-se ainda adequados aos propósitos estabelecidos. Assim, a coloração HE demonstrou a histologia geral dos discos, Picro-Sirius o arranjo das fibras colágenas e Verhoeff e Weigert, as fibras elásticas e elaunínicas.

De modo geral, a análise por microscopia de luz permitiu demonstrar aspectos morfológicos clássicos da degeneração discal, como os descritos por Coventry et al., na população estudada ${ }^{1,50,51}$. Apesar de serem raros os estudos morfológicos dos discos do segmento cervical, sem nunca ter havido um trabalho seminal como de Coventry et al., os mesmos caracteres descritos para o segmento lombar foram visualizados nos discos cervicais, com uma ou outra peculiaridade. A tônica geral desta análise, ainda que absolutamente qualitativa, foi que os discos agruparam-se não tanto de acordo com a faixa etário a que 
pertenciam, mas com o grau de degeneração já verificado através da classificação de Thompson: discos de grupos diferentes mas com classificações macroscópicas semelhantes possuíram características semelhantes. Entretanto, houve casos em que mesmo discos com classificação de Thompson baixa demonstraram algumas características avançadas de degeneração, revelando assim as limitações da avaliação macroscópica. Este fenômeno ocorreu especialmente com alguns caracteres específicos e será comentado adiante.

\subsubsection{Discos cervicais}

\subsubsection{Organização geral dos discos - HE}

A coloração HE permitiu com sucesso a análise da estrutura geral dos discos cervicais. Esta foi realizada de maneira mais adequada nos discos oriundos do GJ e/ou graduação menor de Thompson. Alguns aspectos clássicos inicialmente descritos para discos do segmento lombar foram demonstrados, como a alternância de lamelas no anel. Neste material, entretanto, percebe-se que a orientação do anel anterior não é exclusivamente de fibras longitudinais e circulares. Na verdade, não foi verificado em momento algum a presença de fibras de orientação puramente circular no anel fibroso. A partir da análise combinada das secções sagitais e coronais, percebe-se que o anel anterior é composto por feixes alternantes com orientação predominantemente longitudinal em sua região mais superficial e oblíquas, quase transversais, no setor mais profundo (Figura 13). Estas fibras oblíquas se alternam e não estão dispostas numa única orientação (Figura 14). Também se verifica que não há limite nítido entre as fibras longitudinais do ligamento longitudinal anterior e as fibras longitudinais mais externas do anel. É somente com a detecção das fibras oblíquas mais superficiais que se distingue claramente o que é anel fibroso (Figura 13A). Nestes espécimes jovens nota-se também o predomínio do componente fibroso, com poucos condrócitos no interior do anel (Figura 13). 

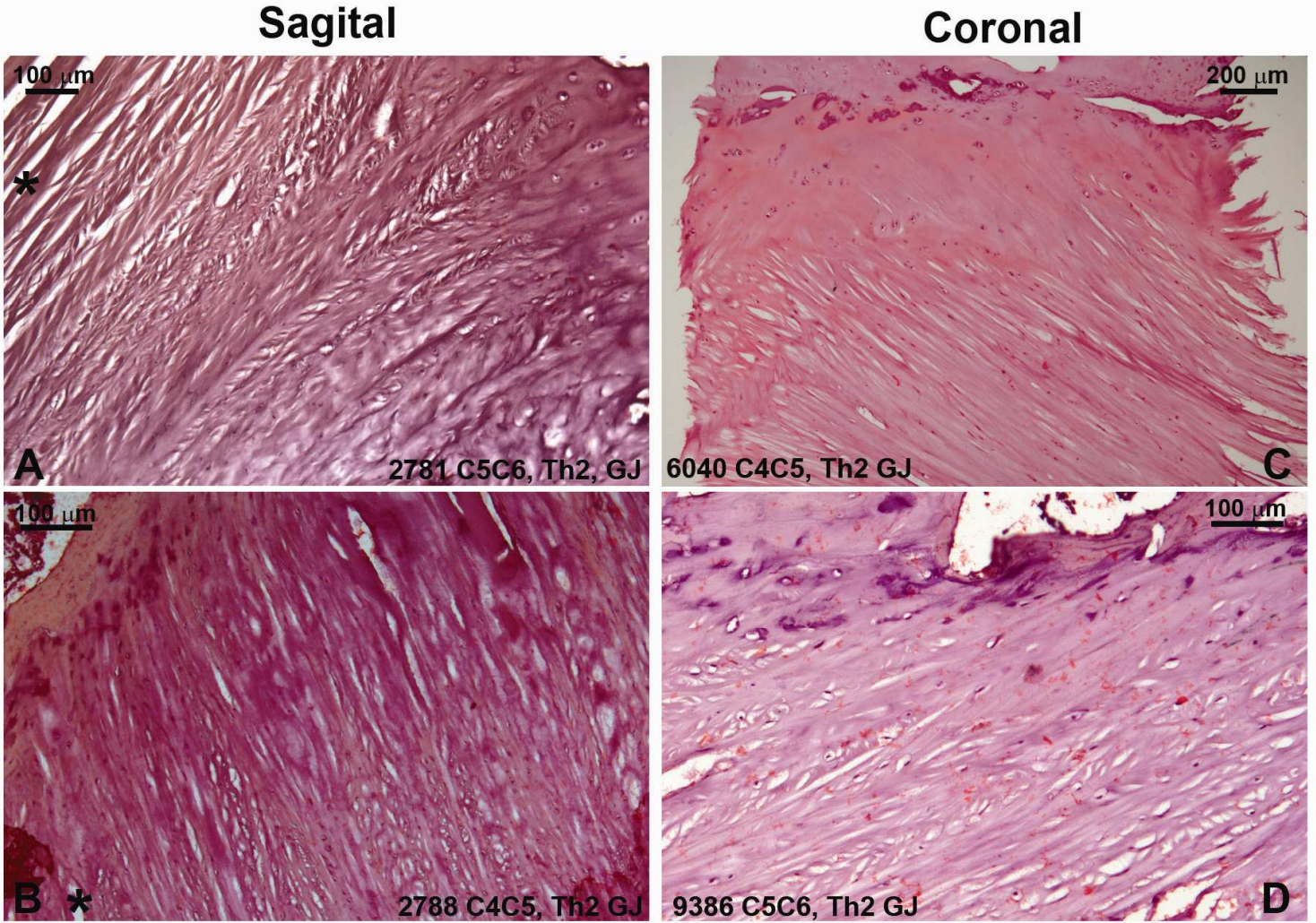

Figura 13 - Discos cervicais, anel anterior. Secções sagitais ( $\underline{13 A}$ e $\underline{13 B})$ e coronais ( $\underline{13 C}$ e $\underline{13 D})$ de discos com baixo grau de degeneração na macroscopia. Secções sagitais demonstram o arranjo predominantemente longitudinal das lamelas, alternando-se na região mais profunda do disco e tornando-se progressivamente mais oblíquo. Cortes coronais demonstram claramente osso esponjoso e placa cartilagínea na região superior e lamelas com orientação oblíqua inserindo-se na placa. $\left({ }^{*}\right)$ - região anterior.

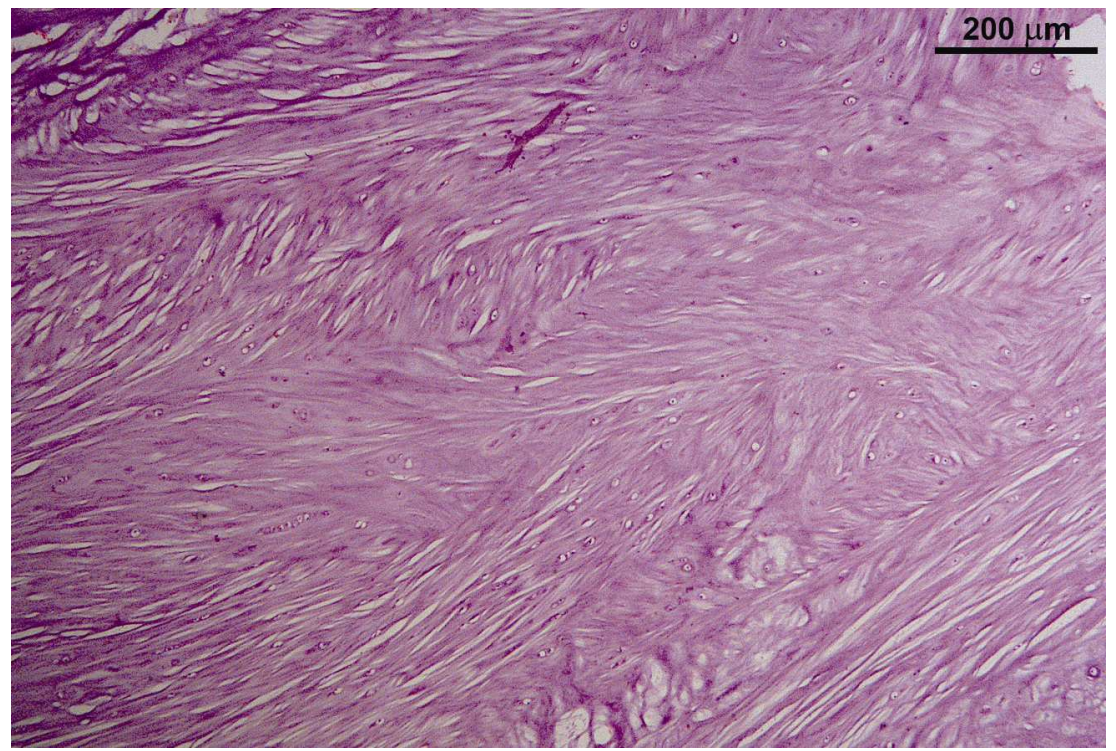

Figura 14 - Disco cervical, espécime 2789 C4C5, orientação coronal. Região anterior do anel fibroso demonstrando alternância oblíqua de lamelas. 
Esta mesma região em discos de $\underline{\text { Gl }}$ sofreu modificações extensas. O componente fibroso foi quase completamente substituído com aumento do componente cartilagíneo no interior do disco, espessamento da placa vertebral e proliferação de condrócitos a partir da mesma (Figura 15). Assim, o anel em sua região anterior praticamente perde o seu arranjo lamelar típico visível na secção sagital (Figuras 15A e $\underline{\text { 15B }}$ ), porém um resquício de arranjo predominantemente longitudinal ainda é visível nas seções coronais (Figuras 15C e 15D).

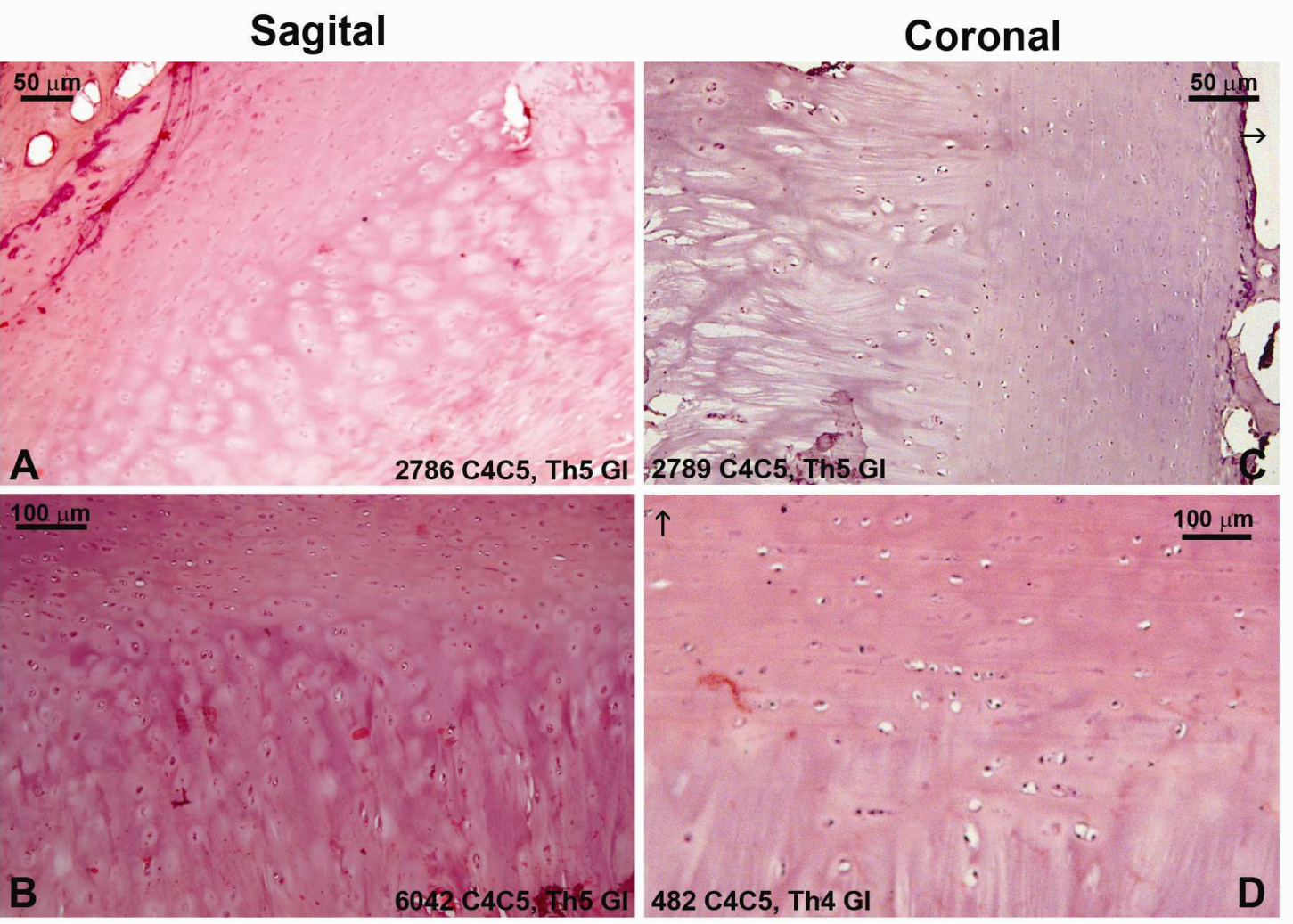

$\underline{\text { Figura } 15}$ - Discos cervicais, anel anterior. Secções sagitais ( $\underline{\mathbf{1 5 A}}$ e $\underline{\mathbf{1 5 B}})$ e coronais $(\underline{\mathbf{1 5 C}}$ e $\underline{\mathbf{1 5 D}})$ de espécimes com elevado grau de degeneração. Arranjo de lamelas frouxas visto na Figura $\underline{13}$ foi aparentemente perdido nas secções sagitais, embora algumas fibras longitudinais possam ser vistas nas secções coronais. Ainda são evidentes a proliferação de condrócitos e espessamento da placa vertebral. Setas indicam a direção cranial nos espécimes com orientação coronal. 


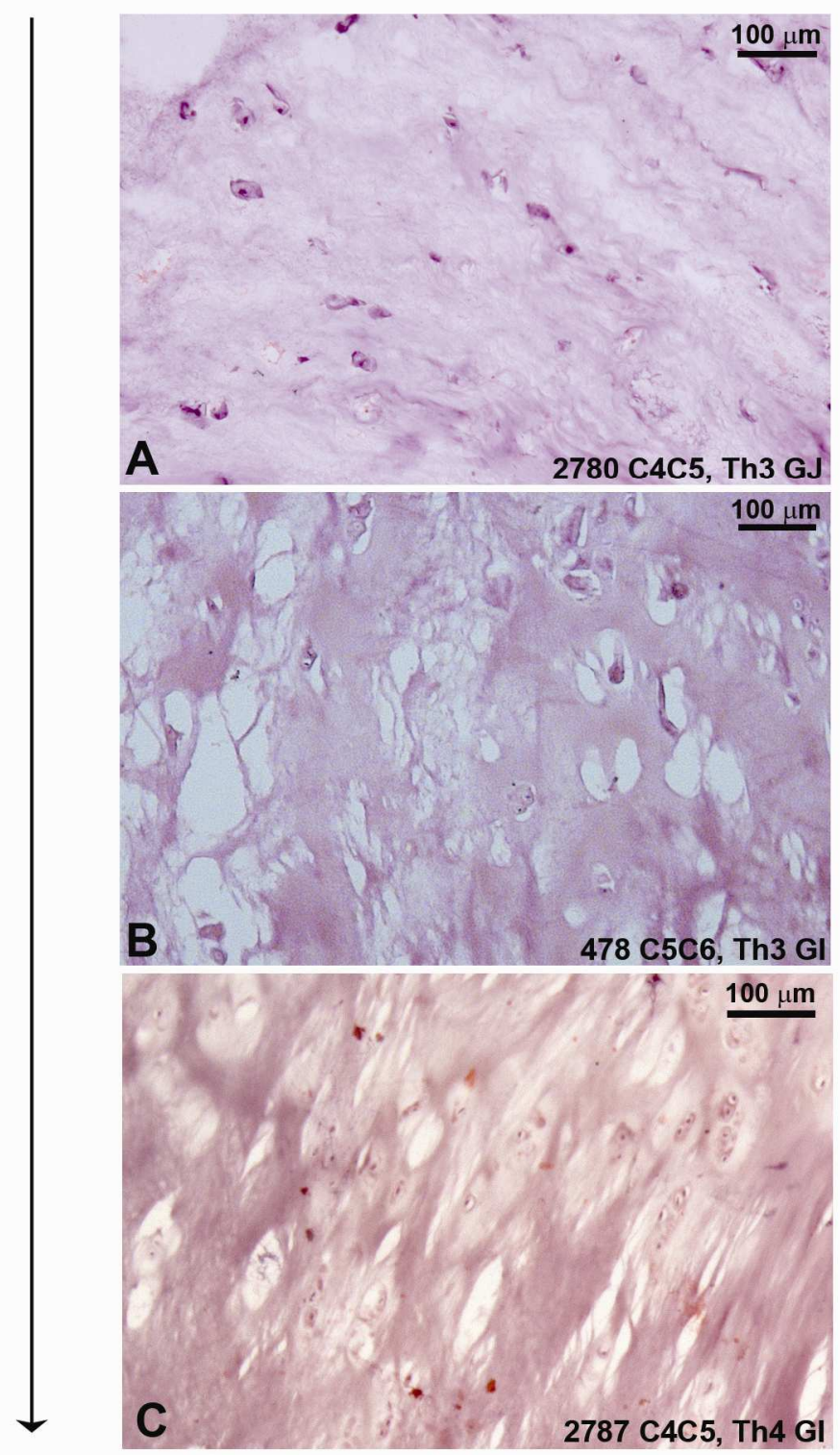

Figura 16 - Discos cervicais, região central. Seç̧ões sagitais. Aspecto nuclear classicamente descrito para o núcleo em 16A, predomínio de fibroblastos e feixes conjuntivos frouxos, sem orientação particular. 16B , adensamento da matriz conjuntiva e presença de condrócitos. Estes se tornam mais frequentes e o tecido adquire características francamente cartilagíneas em $\underline{\mathbf{1 6 C}}$. A seta indica a presumível progressão das alterações degenerativas.

Foram raros os espécimes cervicais, de ambos os grupos, em que se identificou facilmente uma região central distinta do anel fibroso. A ausência desta delimitação foi comum inclusive nos espécimes jovens; um núcleo morfologicamente distinto sob a coloração $\mathrm{HE}$ como mostrado na Figura 16A foi excepcional. Um padrão adensado, com populações de condrócitos agrupadas em cadeias ou clusters conforme demonstrado em estágio inicial na Figura 16B e avançado em $\underline{16 C}$ foi o padrão mais encontrado, e deve ser o denominado típico para o segmento cervical. 
Sagital
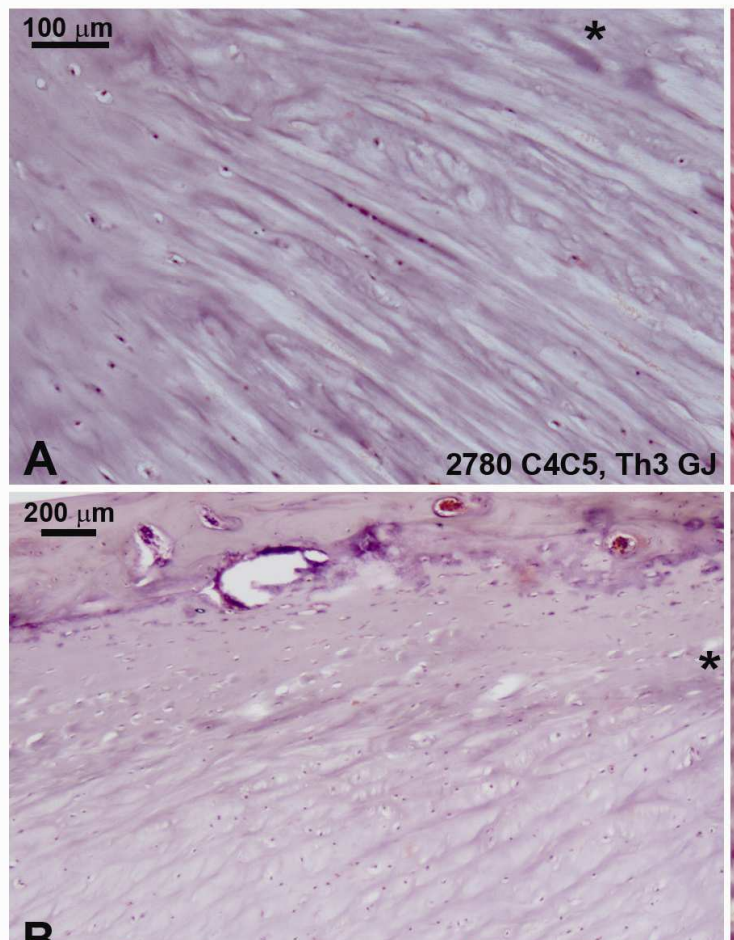

B 4410 C4C5, Th2 GJ 2789 C5C6, Th2 GJ
Coronal
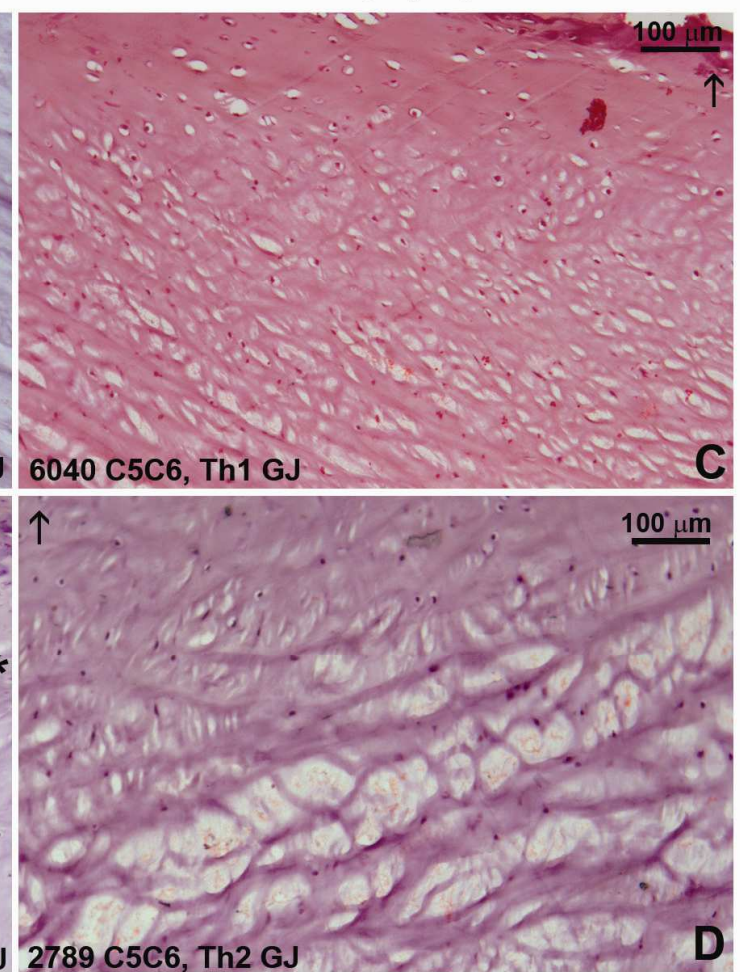

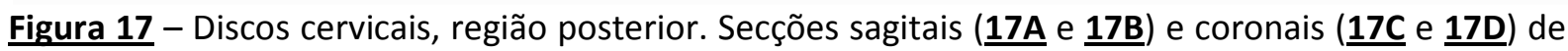
discos com baixo grau de degeneração na macroscopia. Arranjo predominantemente longitudinal e discretamente oblíquo é visível nas secções sagitais. Por outro lado, a quantidade e espessura das lamelas com orientação oblíqua é bem menor que no anel anterior (17C e 17D). Asteriscos demonstram a região anterior nas secções sagitais e as setas, a direção cranial nas coronais.

O anel posterior dos discos com baixo grau de degeneração diferiu do anel anterior pelo nítido predomínio de fibras com disposição longitudinal (Figura 17). Nos cortes sagitais, percebe-se que a orientação destas fibras não é perfeitamente longitudinal, mas oblíquas no plano sagital também (Figuras 17A e 17B)$)$. Há que se considerar, entretanto, que a placa vertebral não é perfeitamente horizontal mas discretamente inclinada também em relação ao plano transverso (Figura 10). Assim, estas fibras longitudinais são mais verticais do que aparentam. No plano coronal, visualizam-se fibras oblíquas bem mais delgadas e em menor número; não se percebem fibras com orientação puramente circular / transversal (Figuras

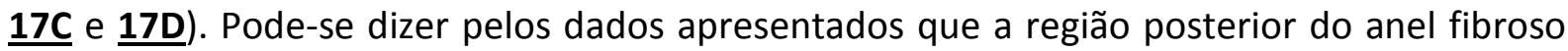
cervical é inteiramente composta pelas fibras longitudinais. 
Sagital
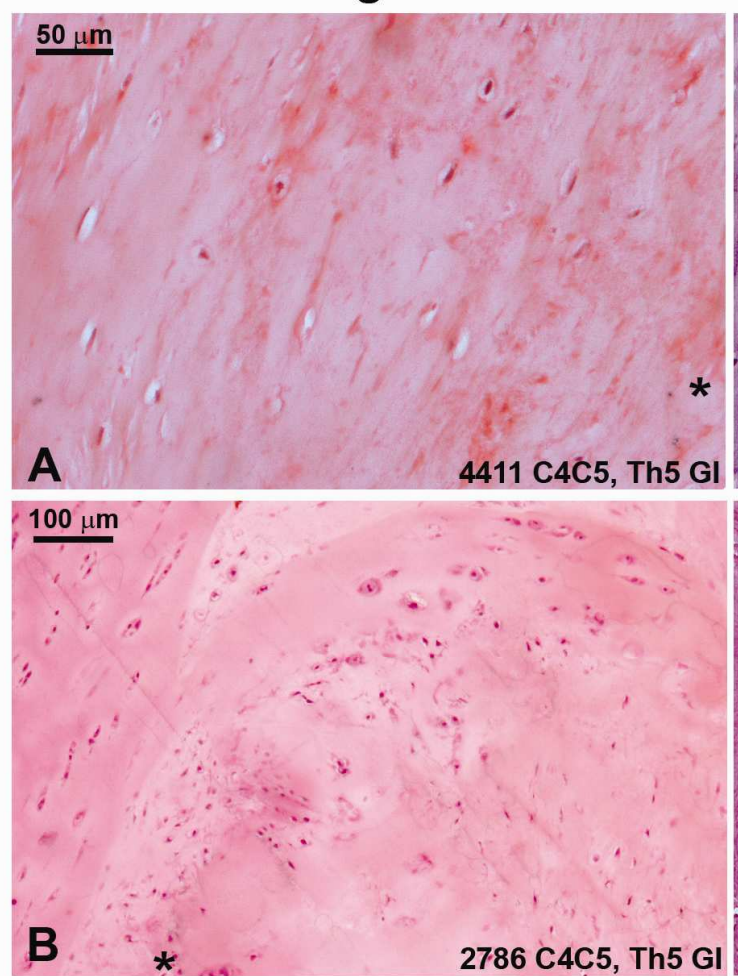

Coronal
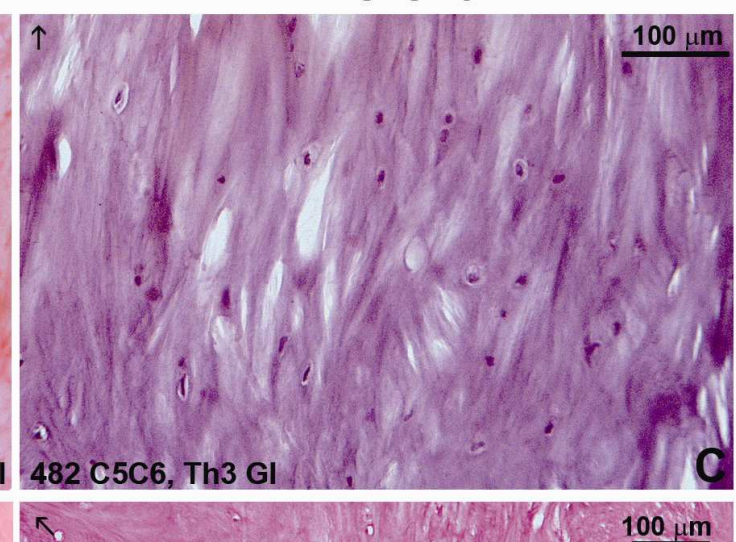

$\underline{\text { Figura } 18}$ - Discos cervicais, anel posterior. Secções sagitais $(\underline{\mathbf{1 8 A}}$ e $\underline{\mathbf{1 8 B}})$ e coronais $\underline{(\mathbf{1 8 C}}$ e $\underline{\mathbf{1 8 D}})$ de discos com elevado grau de degeneração. Completa perda do padrão de feixes nos espécimes seccionados no plano sagital, com uma matriz de características cartilagíneas. No exemplar com degeneração um pouco menor $(\underline{\mathbf{1 8 C}})$ ainda se encontra um resquício de

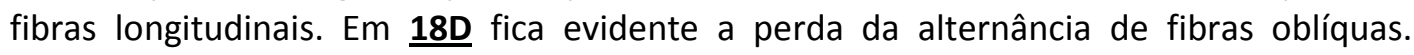
Asterisco denota a região anterior nos espécimes sagitais e as setas, orientação superior nos coronais.

A região posterior do anel fibroso sofre transformação análoga à região anterior já descrita (Figura 18). O componente fibroso encontra-se susbtituído por matriz cartilagínea, chegando até à completa substituição e desaparecimento do padrão de feixes em espécimes com Thompson elevado. Nas secções coronais o fenômeno se repete ( $\underline{\mathbf{1 8 C}}$ e $\underline{\mathbf{1 8 D}})$.

Algumas das características consideradas "clássicas" para a degeneração discal foram especialmente evidentes nestes espécimes quanto à placa vertebral e aos grupos de condrócitos dispersos pelo interior dos discos. Exemplos da progressão das alterações nestas regiões encontram-se na Figura 19. A placa vertebral progressivamente se espessa e há aumento do componente cartilagíneo na região dos feixes. De maneira similar, praticamente 
não se observa condrócitos no interior do disco em espécimes pouco degenerados (19D). Entretanto, estes são progressivamente encontrados no interior do disco até formar grandes aglomerados (19F).

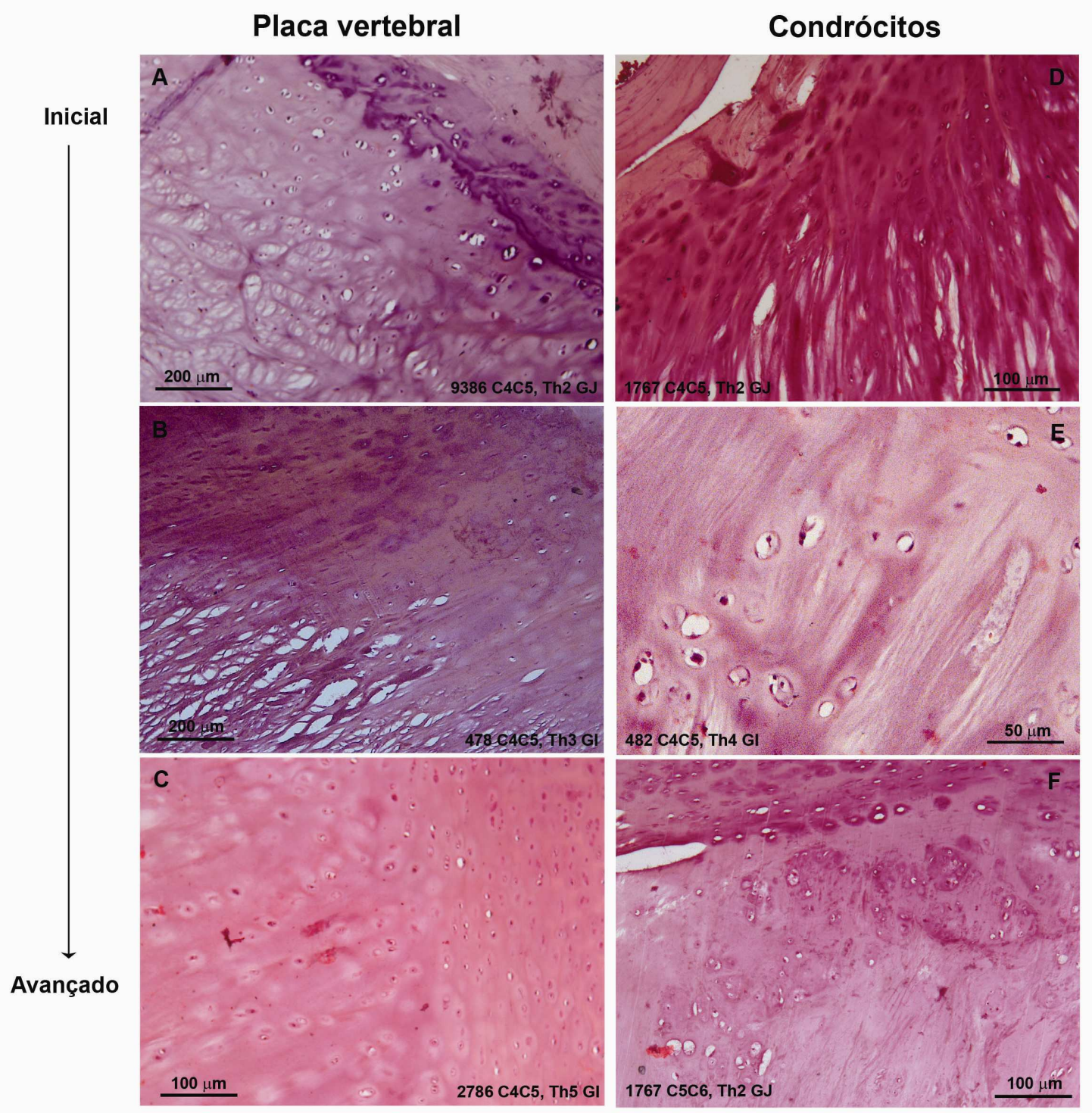

Figura 19 - Características morfológicas classicamente associadas à degeneração discal. A-C, morfologia da placa vertebral. Inicialmente bem delimitada (19A), hipertrofia progressiva $\underline{(19 B})$, com perda do padrão de feixes alternantes e suas inserções até o completo desaparecimento destes feixes $(\underline{\mathbf{1 9 C}})$ e exacerbada proliferação da placa vertebral. $\underline{\mathbf{D}-\mathbf{F}}$, presença de condrócitos no interior do disco. Restritos à placa vertebral (19D), os condrócitos gradualmente podem ser encontrados no interior do anel fibroso, incialmente isolados (19E) e em grupos (19F). Em 19E-F, padrão em feixes do anel fibroso também desaparecido. Seta à esquerda indica sentido presuntivo das alterações senescentes; correlação etária a ser realizada após desmascaramento da randomização. 
Notou-se ainda à análise dos caracteres gerais que nem sempre a classificação de Thompson correlacionou-se perfeitamente com os achados degenerativos sob maior aumento. 0 primeiro exemplo encontra-se na Figura 19F - extensos grupos ou clusters de condrócitos encontram-se no interior do disco, sem organização específica refletindo proliferação clonal, o que não condiz com a classificação macroscópica de Thompson 2. Mais exemplos estão demonstrados na Figura 20. Particularmente, o adensamento do anel e a proliferação de condrócitos não se refletiu sempre na classificação de Thompson.

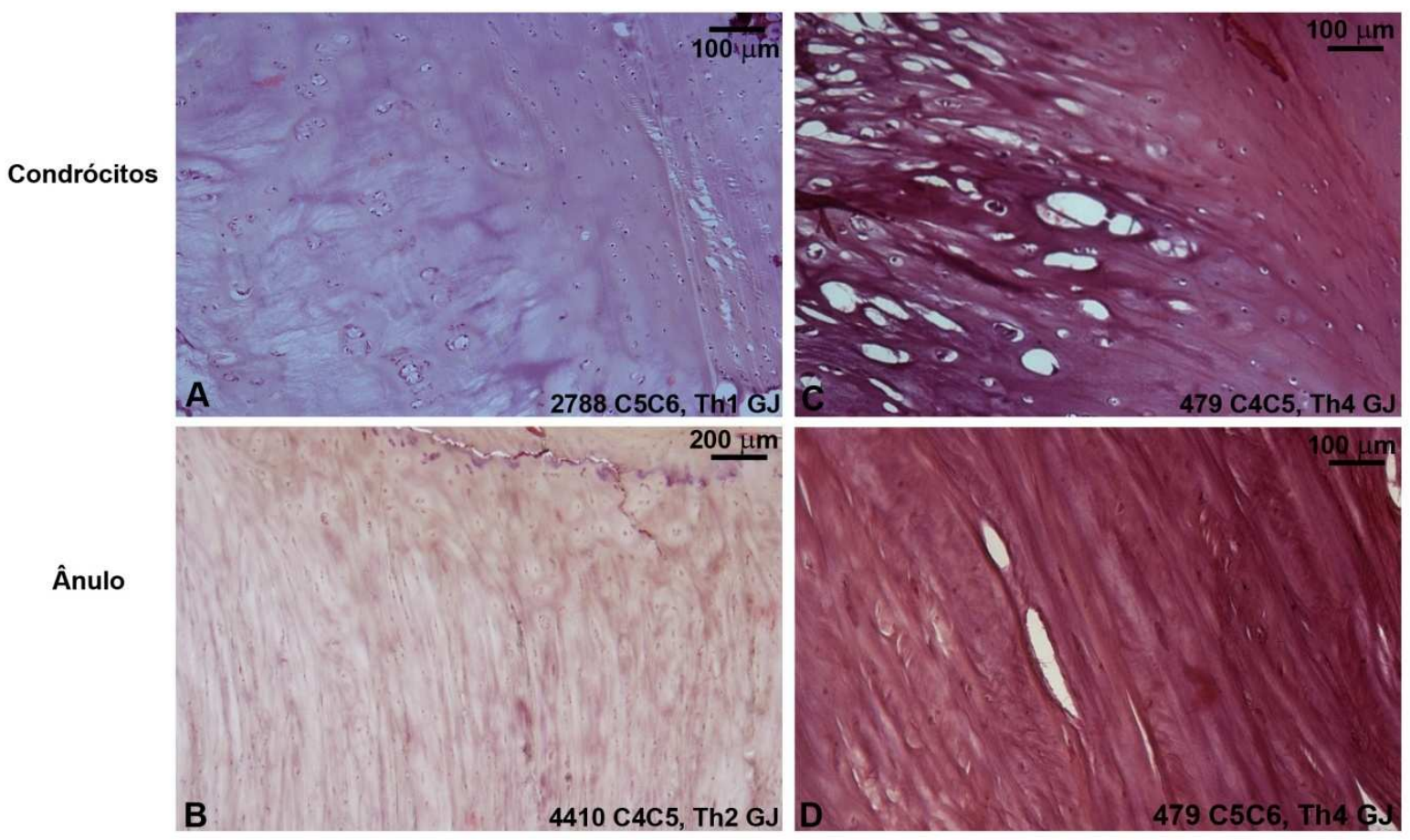

Figura 20 - Espécimes cervicais, HE. Exemplo de caracteres degenerativos presentes sem correlação imediata com o grau de Thompson. $\underline{20 \mathrm{~A}}$ e $\underline{\mathbf{2 0 C}}$ demonstram espécimes com baixo grau de Thompson e presença de condrócitos aos pares e em grupos (으) e região anterior do anel bastante adensada (20C). 20C e 20D refletem espécimes com as mesmas características histológicas e que receberam grau elevado de Thompson. 


\subsubsection{Feixes conjuntivos - Picro-Sirius}

A organização ultraestrutural dos feixes conjuntivos do anel fibroso foi analisada com sucesso. A análise sob luz normal permitiu um estudo da organização e orientação destes feixes, enquanto a análise sob luz polarizada possibilitou a distinção satisfatória de fibras amarelo/vermelhas, opacas e esverdeadas, correlacionadas com colágenos fibrilares de diferentes comprimentos: I, II e III, respectivamente.

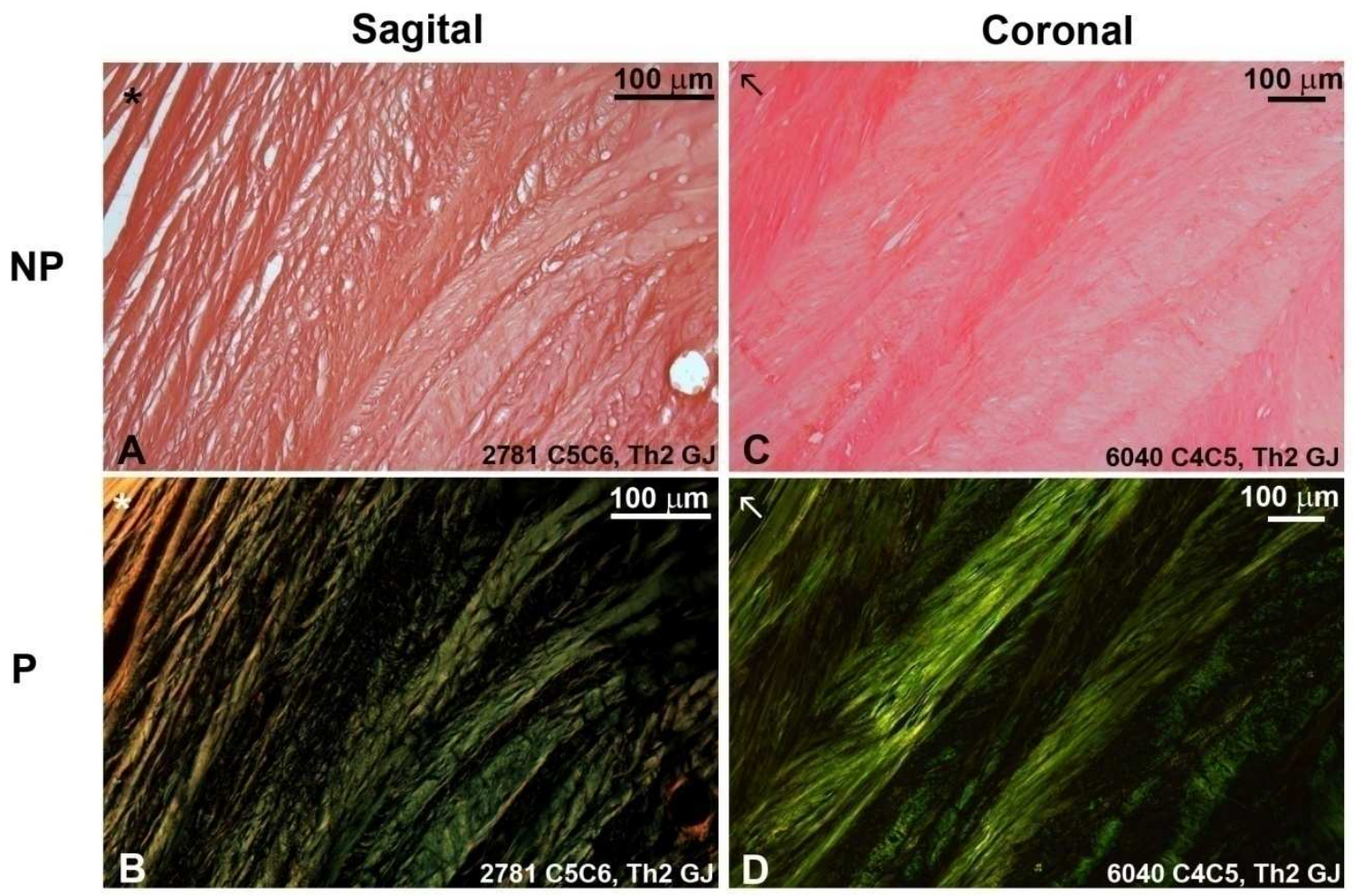

Figura 21 - Discos cervicais, anel anterior, coloração Picro-Sirius. Espécimes com baixo grau de

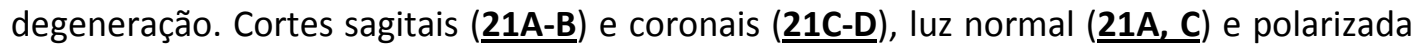
$(\underline{\mathbf{2 1 B}}, \mathbf{D})$. LLA (21A-B, marcado pelo asterisco) com feixes apenas longitudinais e de colágeno I, sem distinção nítida com o anel fibroso, por sua vez constituído de feixes alternantes. Na região mais profunda (21B), notam-se refringências opaca e esverdeada, sugestivas da presença de colágeno II e III, respectivamente. Nas Figuras 21C-D, a seta indica a direção cranial. Os feixes alternantes estão dispostos transversalmente porém inserindo-se de maneira oblíqua. NP - não-polarizada; P - polarizada. 
A Figura 21 demonstra o aspecto típico da região anterior do AF cervical em espécimes com baixo grau de degeneração. A estrutura típica do AF é bem delineada em 21A: a estrutura de feixes alternantes é evidente, anteriormente com feixes longitudinais que não se distinguem do LLA. Profundamente, pecebe-se que camadas de outra orientação estão presentes e ficam patentes imagens coronais (21C e $\underline{\text { 21D)}): ~ e s t a ~ s a ̃ o ~ p r e d o m i n a n t e m e n t e ~ t r a n s v e r s a s, ~}$ porém oblíquas. A análise da refringência indica predomínio de colágeno I nas fibras longitudinais superficiais e colágeno II e III nos setores profundos. Espécimes degenerados como na Figura 22 mostraram o adensamento da região do AF visto nas colorações HE; entretanto, este padrão de feixes não foi absolutamente perdido, com resquício desta organização ainda em $\underline{\mathbf{2 2 A}}$ e $\underline{\mathbf{2 2 C}}$. Houve aumento do componente que não exibe refringência, sugerindo-se o predomínio de colágeno II além do tom esverdeado típico de III. Particularmente evidente é o componente de colágeno I e III na placa vertebral em $\underline{\text { 22B }}$.

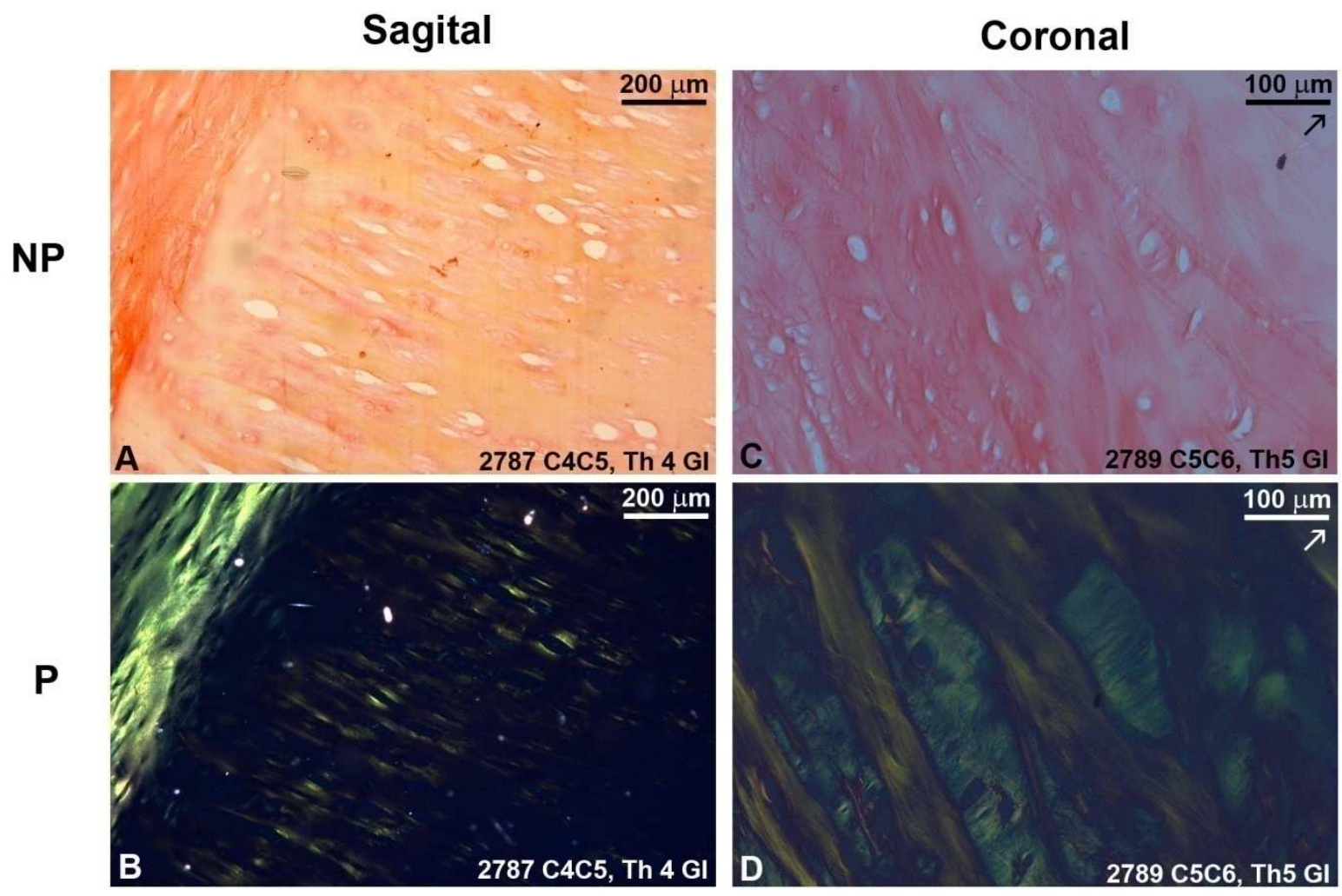

Figura 22 - Discos cervicais, anel anterior, coloração Picro-Sirius. Espécimes com elevado grau de degeneração. AF anterior bem espessado com alteração do padrão de lamelas alternantes (22A). Nas imagens coronais, alguns feixes oblíquos ainda são visíveis (22B) porém o adensamento é evidente. Polarização demonstra aumento da área sem refringência na imagem sagital ( $\underline{\mathbf{2 2}} \mathbf{C})$, mantendo um padrão misto de colágenos - pequeno aumento do componente de colágeno I é evidente em algumas lamelas de 22D, com a ressalva de ainda serem feixes ortogonais. Seta indica a direção cranial nos cortes coronais. NP - nãopolarizada; P - polarizada. 


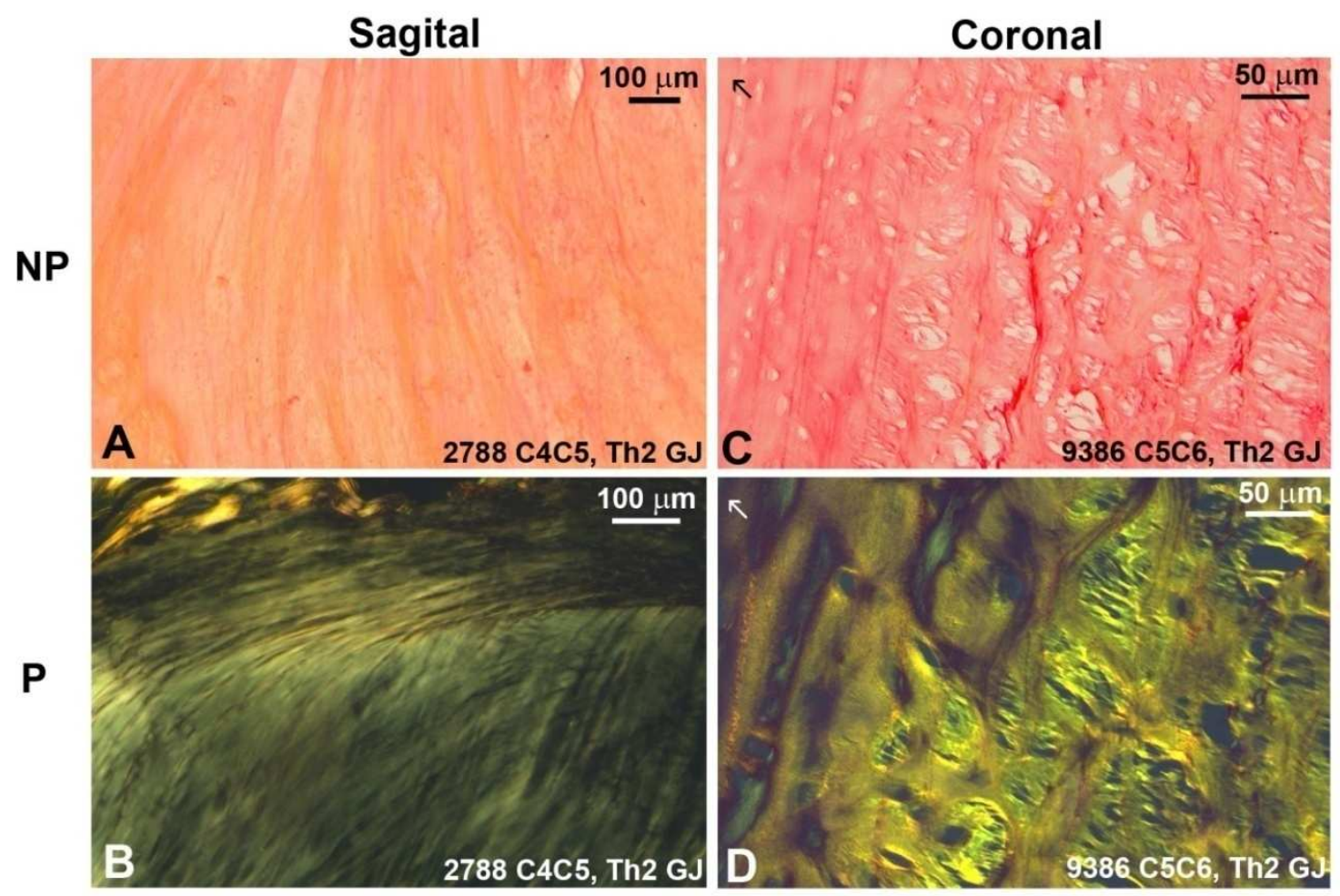

Figura 23 - Discos cervicais, anel posterior, coloração Picro-Sirius. Espécimes com baixo grau de degeneração. Os cortes sagitais demonstram as diferentes lamelas da região posterior do anel fibroso; a visualização sob luz polarizada $(\underline{23 B})$ revela que o componente longitudinal é o predominante. As imagens coronais demonstram um pequeno componente oblíquo que é muito menos espesso que o longitudinal, constituindo pequenas pontes entre os feixes na região posterior do $A F(\underline{23 C}$ e $\underline{23 D})$. Setas indicam a direção cranial nas imagens coronais. NP - não-polarizada; P - polarizada.

A organização típica da região posterior do anel fibroso também foi demonstrada com sucesso, como atesta a Figura 23. O aspecto típico dos setores posteriores do AF é visível, com lamelas predominantemente longitudinais - as fibras transversais não consistem de verdadeiras lamelas, mas pequenas pontes de conjuntivo. Embora uma discreta alternância seja sugerida em $\underline{\text { 23A }}$, 23B demonstra claramente o predomínio das lamelas longitudinais.

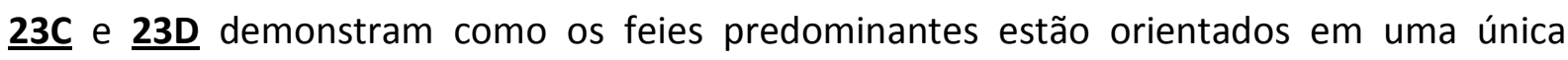
direção, com pequenas pontes entre eles. Nesta região, análise de refringência não demonstra um predomínio claro de uma espécie de colágeno: existem componentes amarelados (tipo I), opacos (tipo II) e esverdeados (tipo III). 


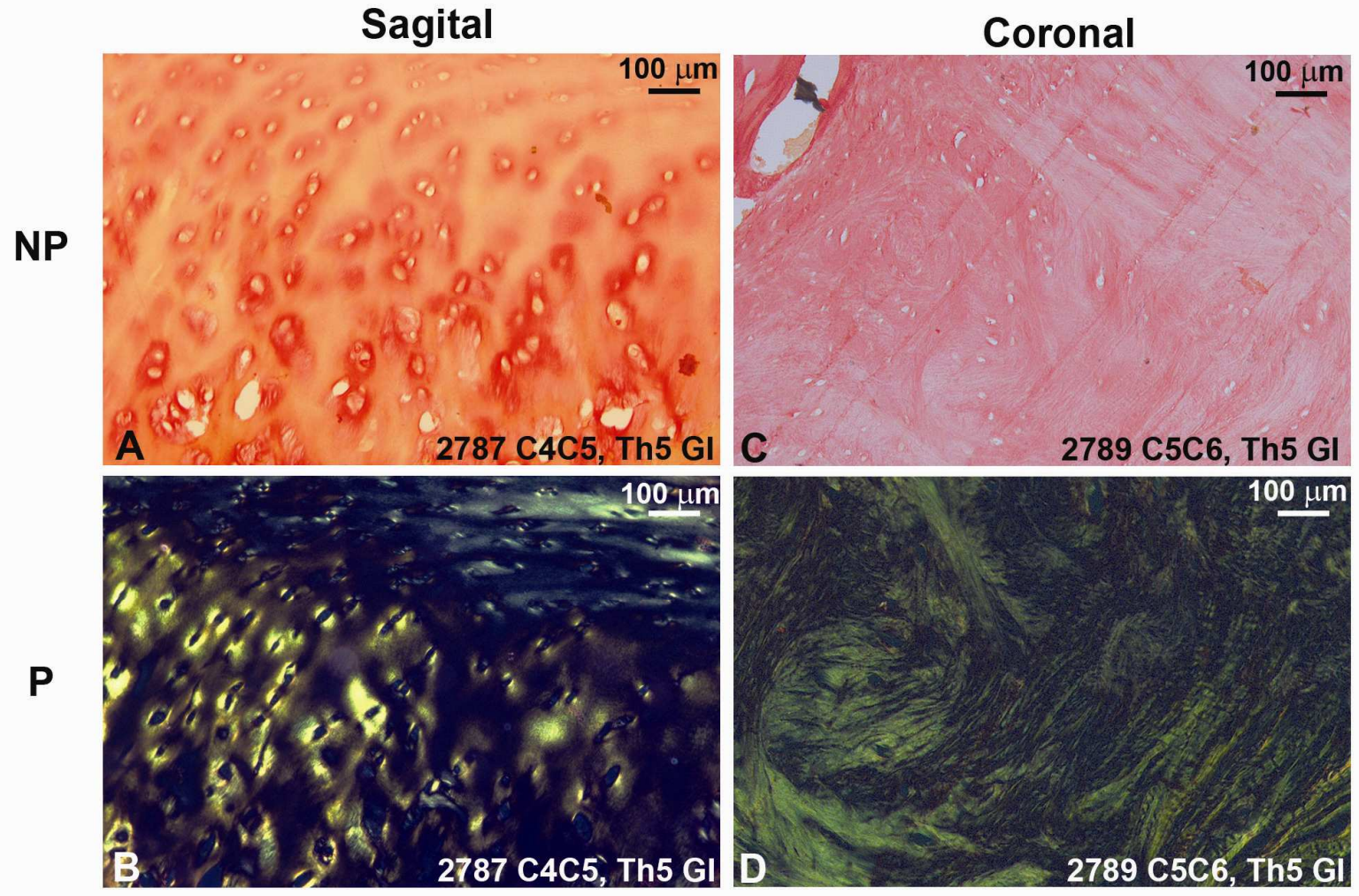

Figura 24 - Discos cervicais, anel posterior, coloração Picro-Sirius. Espécimes com alto grau de

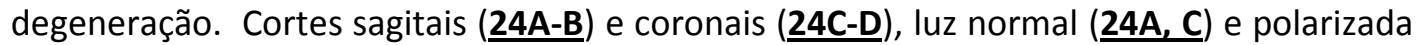
$(\underline{\mathbf{2 4 B}}, \mathbf{D})$. Adensamento e desaparecimento do padrão de lamelar (24A e $\underline{\mathbf{C}})$. Predomínio

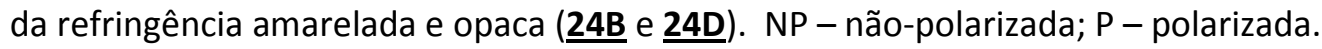

Nos espécimes com elevado grau de degeneração (Figura 24) torna-se evidente a desorganização dos setores posteriores do anel fibroso. Matriz adensada e perda da organização lamelar estão evidentes: as secções coronais demonstram o grau de desorganização (Figuras 23C e 23D). Predomina ainda o colágeno tipo II, com um componente bastante significativo de fibras refringentes amareladas, sugerindo colágeno tipo I (Figuras 23B e 23D). 


\subsubsection{Fibras elásticas}

As técnicas de coloração segundo Verhoeff (elásticas maduras) e resorcina-fucsina de Weigert (elásticas e elaunínicas) demonstraram de maneira bastante satisfatória as fibras do sistema elástico no interior dos discos cervicais (Figura 25). De uma maneira geral, o achado de fibras elásticas no interior do anel fibroso foi homogêneo; não houve discos com presença de fibras elásticas apenas em determinados setores do anel. A região central do disco apresentou menor densidade de fibras elásticas; entretanto, a própria dificuldade em definir um remanescente nuclear atrapalha esta análise - nos dois discos em que um remanescente discal foi observado, não foram encontradas fibras elásticas; a quantidade de espécimes é portanto muito pequena para permitir quaisquer conclusões. Por fim, a detecção de fibras do sistema elástico pelas colorações Verhoeff e Weigert foi perfeitamente congruente, ou seja: não houve detecção de fibras por Weigert em espécimes sem detecção por Verhoeff também.

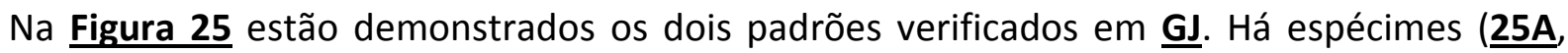
$\underline{\mathbf{2 5 C}}, \underline{\mathbf{2 5 E}}$ e $\underline{\mathbf{2 5 G}}$ ) em que as fibras elásticas são abundantes e orientadas no mesmo sentido dos feixes conjuntivos longitudinais. Não há diferença significativa no conteúdo de fibras visualizadas pelas técnicas de Verhoeff e Weigert. Por outro lado, há espécimes de GJ que apresentam quantidade bem menor de fibras elásticas (Figuras 25B, 25D, 25F e 25H). Não houve como prever a ocorrência ou não de fibras elásticas através da classificação de Thompson; exceto por $\underline{\mathbf{2 5 A}}$ e $\underline{\mathbf{2 5 E}}$, todos os espécimes demonstrados receberam classificação Thompson 2. Houve ainda um espécime (Figura 25D) em que as fibras elásticas nitidamente estão orientadas conforme um feixe oblíquo, e não longitudinal. 

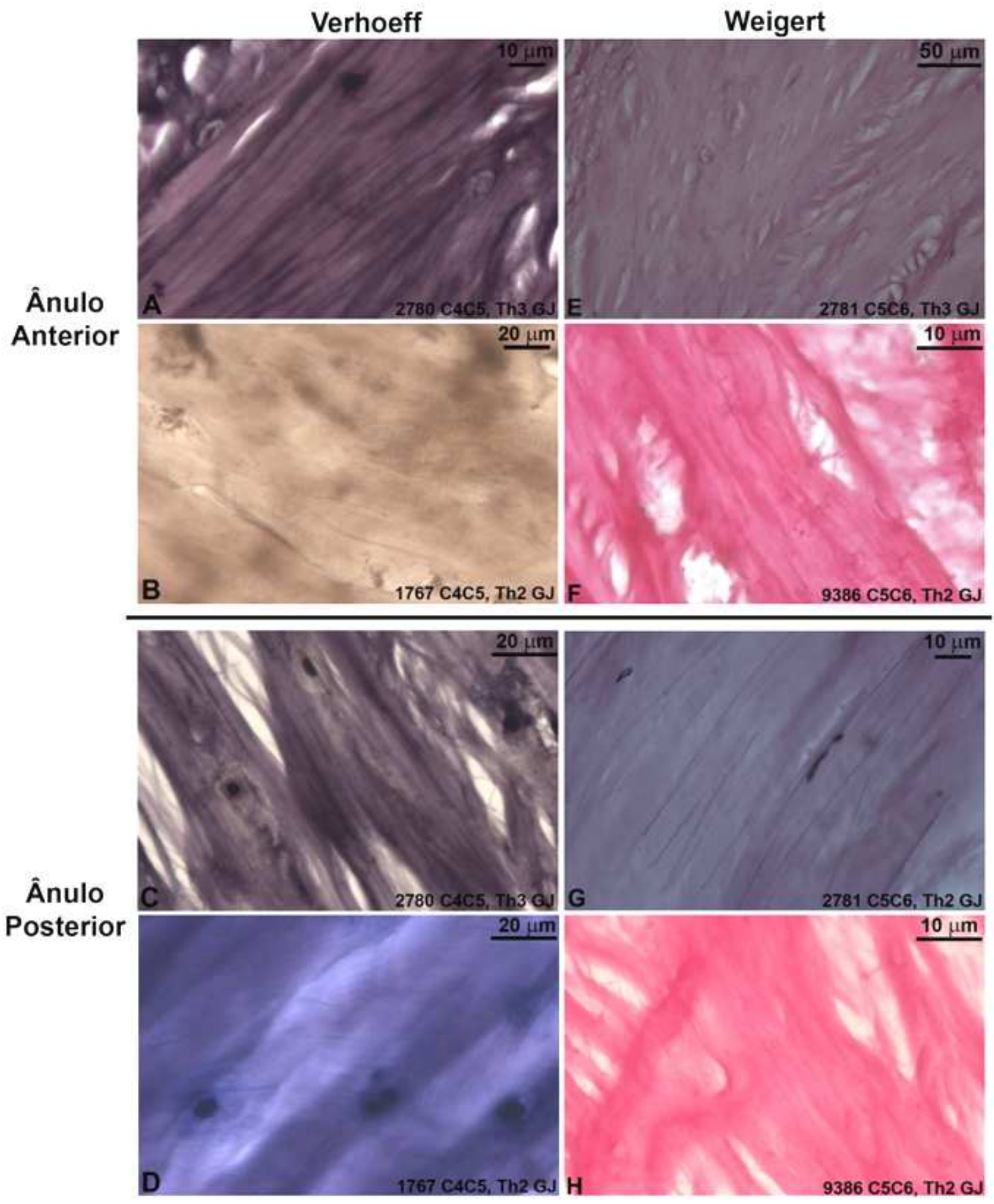

Figura 25 - Discos cervicais, colorações Verhoeff (25A-D) e Weigert (25E-H), Grupo Jovem. Fibras elásticas demonstradas em ambas as colorações com bastante sucesso; entretanto, a visualização demonstrou espécimes com fibras abundantes em todo o anel (25A e 25C; $\underline{\mathbf{2 5 E}}$ e $\underline{\mathbf{2 5 G}}$ ) e outros com quantidade menor das mesmas fibras (demais figuras). Não houve espécimes com padrões discrepantes nas regiões anterior e posterior do anel fibroso. 
Apesar de ter havido exemplares de $\underline{\text { GJ }}$ que apresentavam comparativamente menos fibras

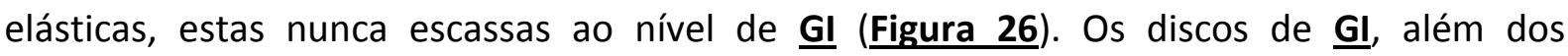
caracteres cartilagíneos predominantes, exibiram poucas ou até nenhuma fibra elástica. A exceção ficou por conta de um único cadáver, 323, que mostrou abundantes fibras elásticas de maneira homogênea ao longo do disco (Figura 27); ainda assim, isto ocorreu de maneira absolutamente distinta de $\underline{\mathbf{G J}}$. Ambos os discos cervicais de 321 eram quase que inteiramente compostos por matriz cartilagínea; fibras elásticas em profusão foram demonstradas pela coloração de Verhoeff (Figura 27A) porém sem orientação definida, dispersas por entre os condrócitos. Por outro lado, a coloração dos mesmos discos segundo Weigert demonstrou fibras orientadas com os feixes conjuntivos remanescentes (Figura 27B), tornando evidente os diferentes componentes de fibras elásticas e elaunínicas.

A ausência de fibras elásticas nos espécimes de $\underline{\text { GI }}$ e a marcante diferença em relação a $\underline{\mathbf{G J}}$ tornou-se ainda mais significativa quando se verificou que os ligamentos longitudinais, tanto anterior quanto posterior, exibiram fibras elásticas mesmo nos discos de GI (Figura 28). Este achado serviu, em primeiro lugar, como uma forma de "controle interno positivo", demonstrando que a ausência de fibras elásticas em GI não foi uma deficiência do método. $A$ perda de fibras elásticas, pelo menos na magnitude observada, é um processo específico do disco (Figura 28). 

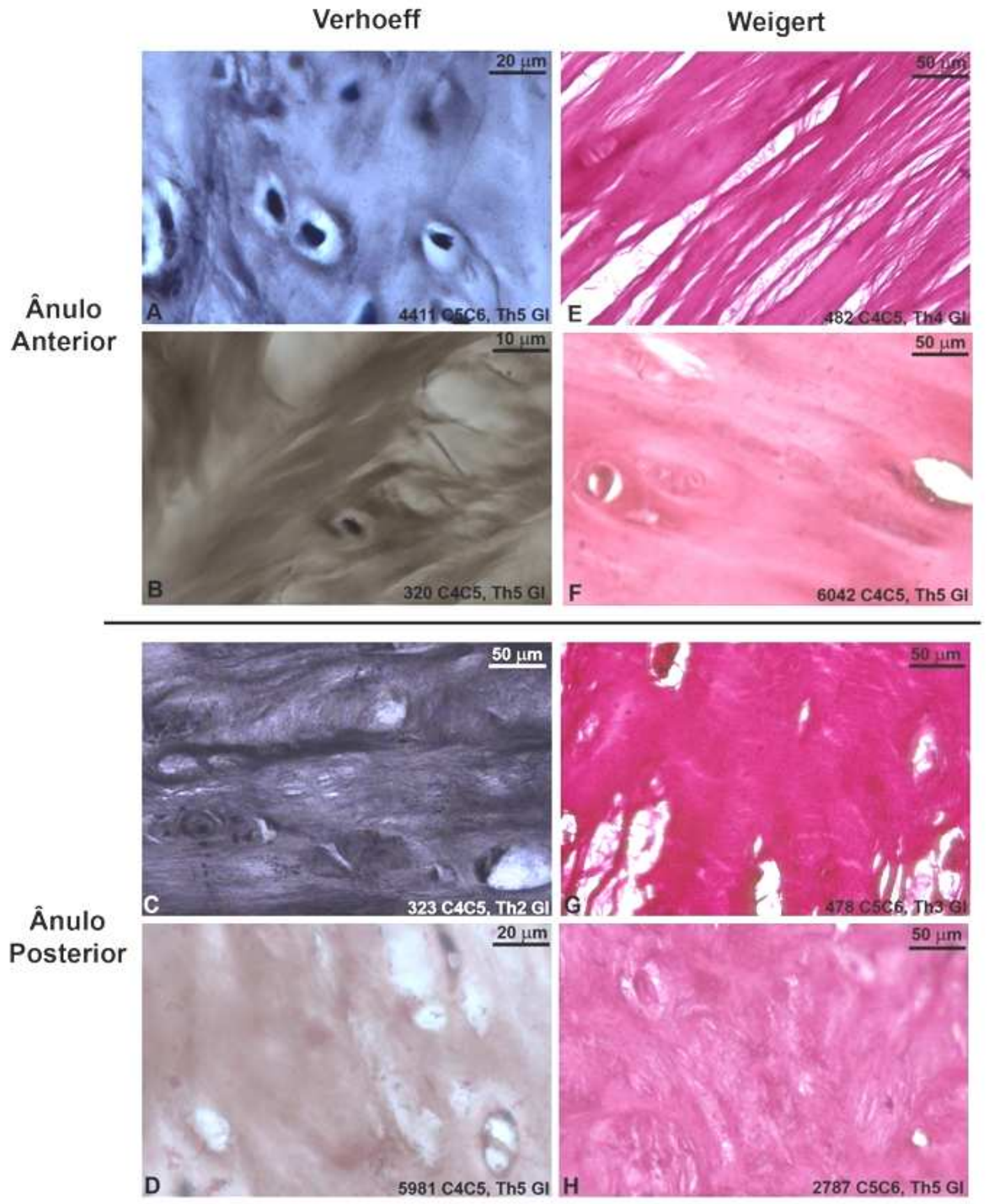

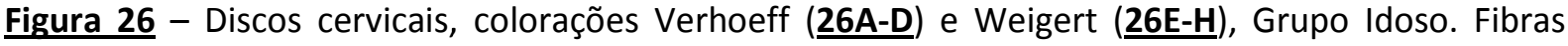
elásticas praticamente ausentes destes espécimes. Figuras oriundas de 8 cadáveres distintos demonstram praticamente ausência de fibras elásticas e elaunínicas nos discos cervicais do Grupo Idoso; demais características cartilagíneas também estão demonstradas. 

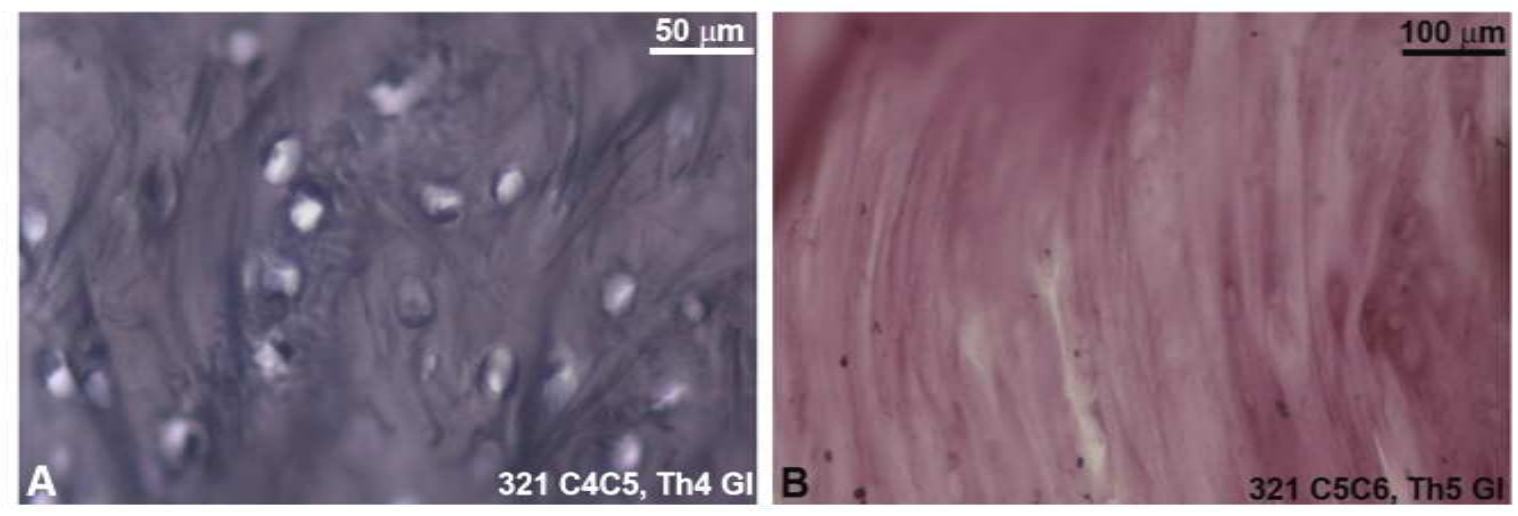

Figura 27 - Espécime 321, discos cervicais, região posterior do anel. Único espécime cervical idoso em que foram encontradas fibras elásticas em quantidade significativa. Observou-se que, na mesma região do disco, as fibras na coloração de Verhoeff $(\underline{\mathbf{2 7 A}})$ não possuem uma orientação definida, enquanto que na coloração de Weigert (27B) estas estão em paralelo com o feixe conjuntivo. Sugere-se assim que as fibras elásticas maduras não possuem arranjo, e as elaunínicas estão em paralelo, ao menos neste exemplo. 

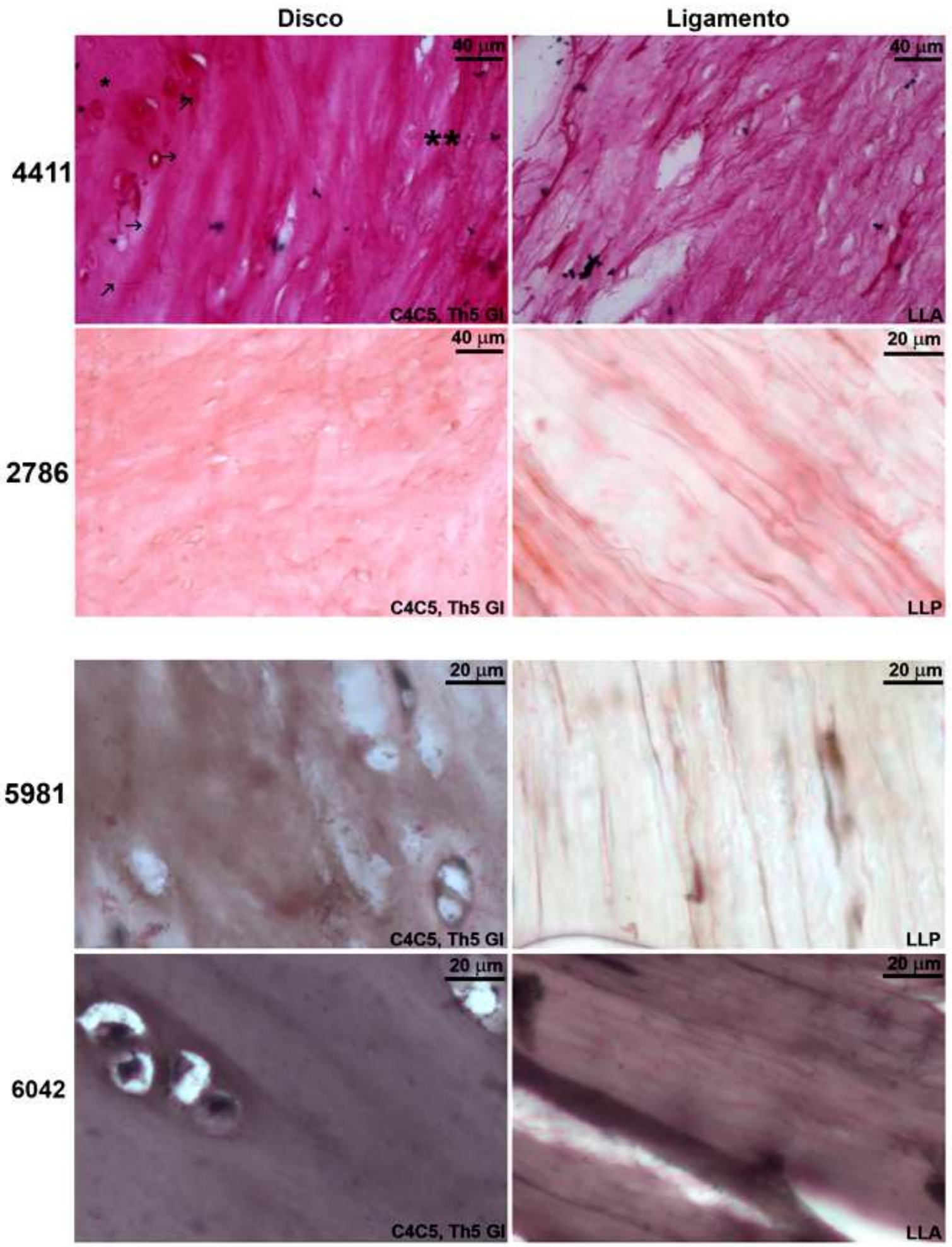

Figura 28 - Espécimes cervicais do Grupo Idoso. Exemplos da presença de fibras elásticas nos ligamentos longitudinais apesar da sua ausência no interior dos discos. Estas fibras elásticas no ligamento longitudinal funcionam como um "controle positivo" interno para verificar o sucesso da reação. O espécime 4411 C4C5 é particularmente feliz: a ausência de fibras elásticas na região anterior do disco permite detectar o limite entre disco (*) e ligamento longitudinal $\left({ }^{* *}\right)$; o limite em si está marcado pelas setas. 4411 e 2786: Weigert; 5981 e 6042: Verhoeff. 


\subsubsection{Discos lombares}

4.3.2.1 Organização geral dos discos - HE

As técnica de HE visualizou satisfatoriamente as características histológicas gerais dos discos do segmento lombar. Assim como no segmento cervical, não houve disco lombar completamente isento de alterações degenerativas; mesmo aqueles com classificação Thompson I apresentaram algumas discretas alterações degenerativas típicas.

A morfologia de todos os setores discais ficou mais evidente nos espécimes de $\underline{\mathbf{G J}}$. A disposição típica da região anterior do AF está demonstrada na Figura 29. Fica particularmente claro nesta figura a disposição de lamelas alternantes deste setor; nos cortes coronais, fica também evidente que as fibras não são transversais, porém oblíquas (Figura 29D). Há poucos condrócitos no interior do anel, a placa vertebral é estreita e o componente fibroso do disco predomina. Em geral, estes discos pertenceram ao GJ, porém, como mostrado em 29D, discos de $\underline{\text { GI }}$ e baixo grau de degeneração apresentaram aspecto morfológico semelhante. 


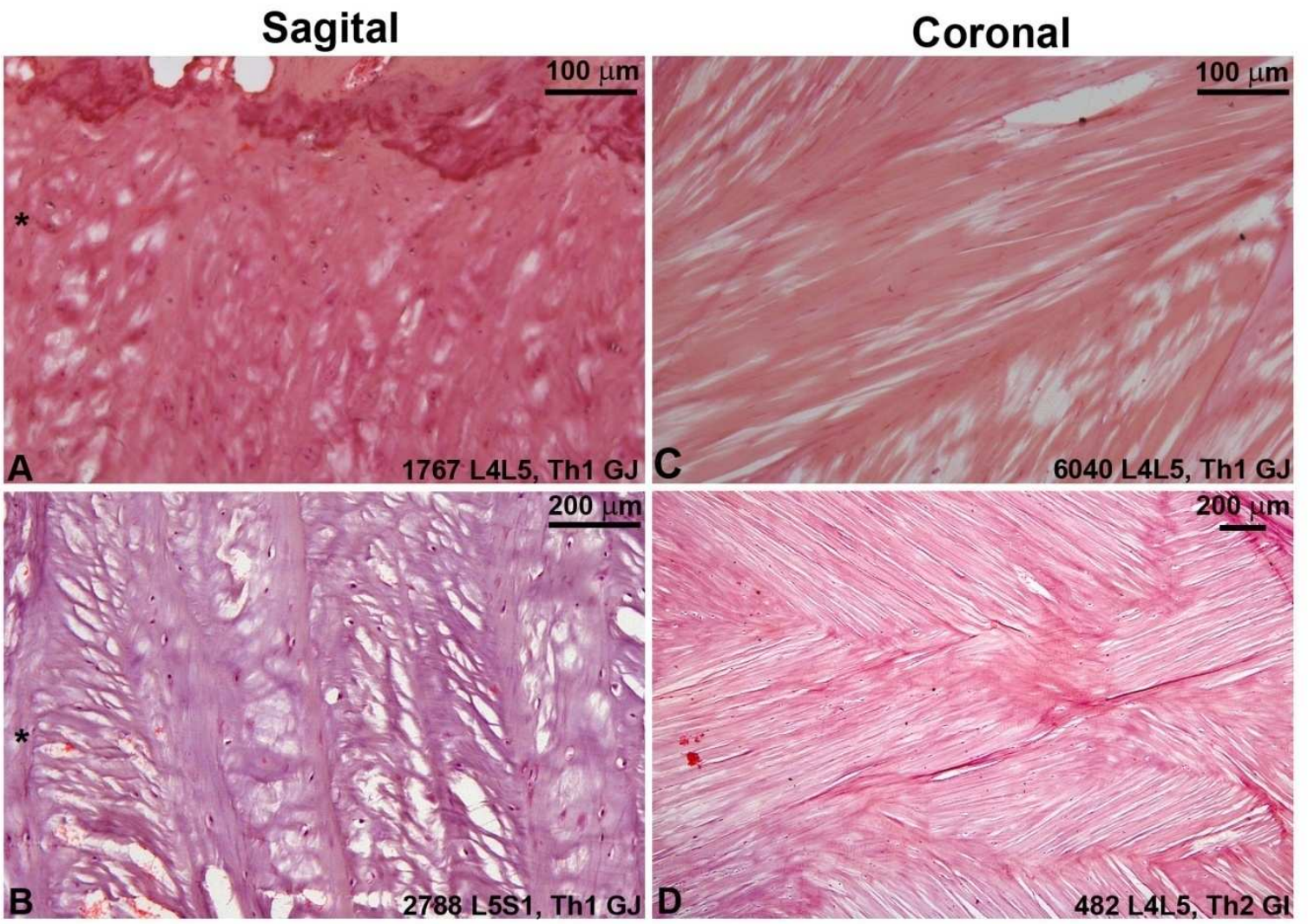

Figura 29 - Espécimes lombares com baixo grau de degeneração, anel anterior, coloração HE. Cortes sagitais $(\underline{\mathbf{A}}, \underline{\mathbf{B}})$ e coronais $(\underline{\mathbf{C}}, \underline{\mathbf{D}})$. Exemplos da disposição típica do anel anterior: lamelas de tecido conjuntivo alternando-se, com disposição oblíqua nos cortes coronais. $\mathrm{O}$ asterisco indica a região anterior nos cortes sagitais.

Por outro lado, espécimes com elevado grau de degeneração apresentaram características morfológicas específicas, como demonstrado na Figura 30: adensamento e perda do padrão de lamelas alternantes, presença de clusters de condrócitos e proliferação cartilagínea até completa perda da organização típica do AF conforme visível na Figura 30D. Fissuras transversais também estão evidentes na Figura 30B.

A região central dos discos lombares está demonstrada na Figura 31. Os espécimes agrupam-se conforme sua morfologia e não o grupo ao qual pertencem: espécimes Thompson 3 são indistinguíveis. Entretanto, de uma maneira geral os núcleos jovens de um mesmo grau de degeneração possuem matriz mais frouxa (Figura 31C). A progressão degenerativa é evidente na Figura 31: núcleos frouxos e praticamente acelulares são 
invadidos por condrócitos, sua matriz torna-se mais densa e eventualmente assume características cartilagíneas.

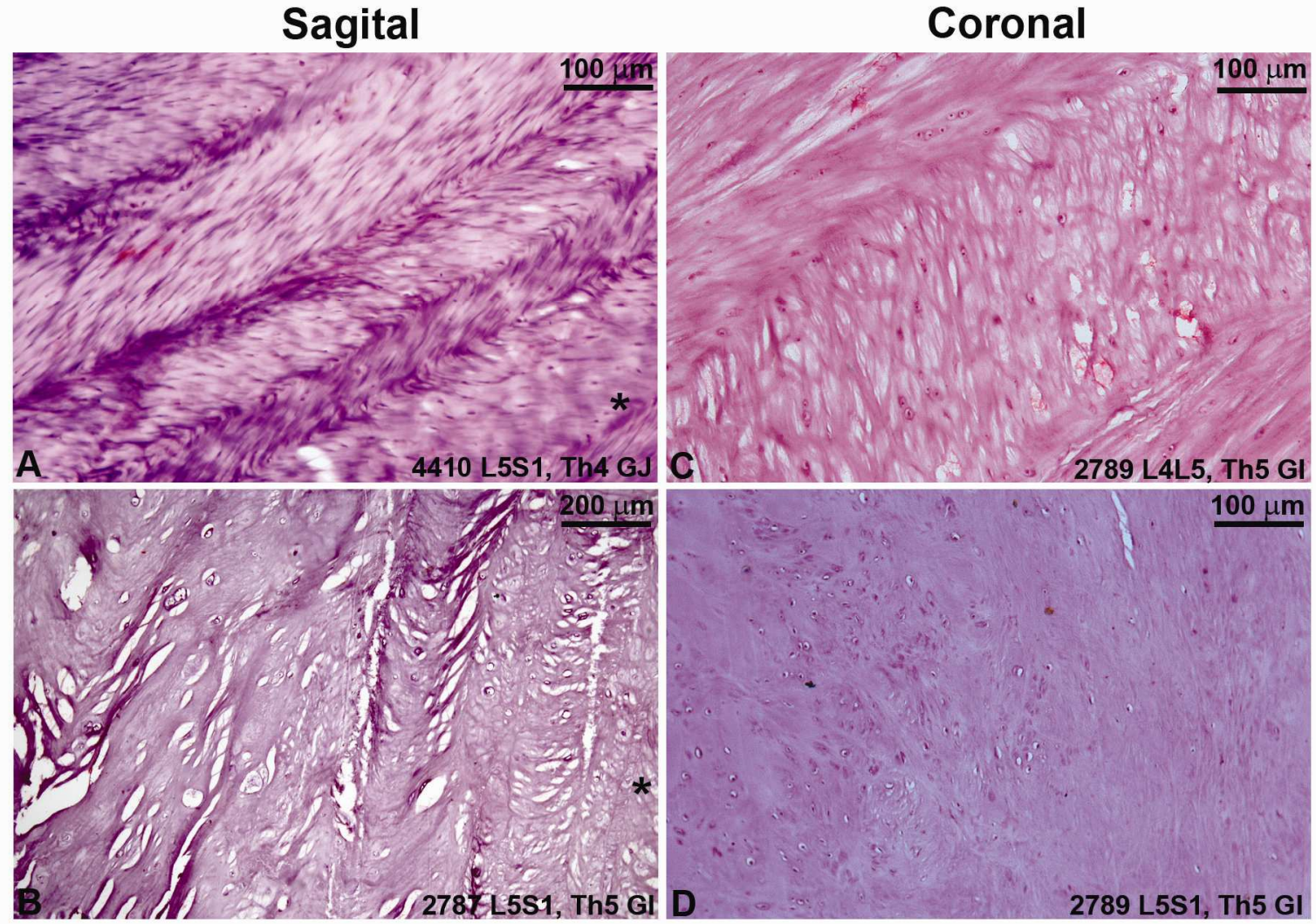

Figura 30 - Espécimes lombares com elevado grau de degeneração, anel anterior, coloração HE. Cortes sagitais $(\underline{\mathbf{A}}, \underline{\mathbf{B}})$ e coronais $(\underline{\mathbf{C}}, \underline{\mathbf{D}})$. Variados graus de degeneração demonstrados na região anterior do AF. Aumento do componente cartilagíneo, clusters de condrócitos e perda do padrão de feixes alternantes até completa desorganização do disco (ㅁ) . Algumas fissuras são evidentes perpendiculares aos feixes de conjuntivo (ㅌ). $O$ asterisco indica a região anterior nos cortes sagitais.

A região posterior do AF também apresenta características distintas de acordo com o grupo a que pertence (Figura 32). Nos espécimes com baixo grau de degeneração, foi demonstrado novamente o predomínio das fibras longitudinais. Entretanto, nas seç̧ões coronais fica evidente um componente menor de fibras oblíquas, quase transversais (iguras 32B e $\underline{\text { 32D }}$ ). Este padrão se assemelha mais ao verificado na região anterior do AF, em contraste com a região posterior dos discos do segmento cervical. Nas secções sagitais, por outro lado, mais uma vez fica claro que o componente mais significativo é longitudinal, com uma inserção obliqua neste plano (Figuras 32A e $\underline{32 C}$ ). 


\section{Thompson}

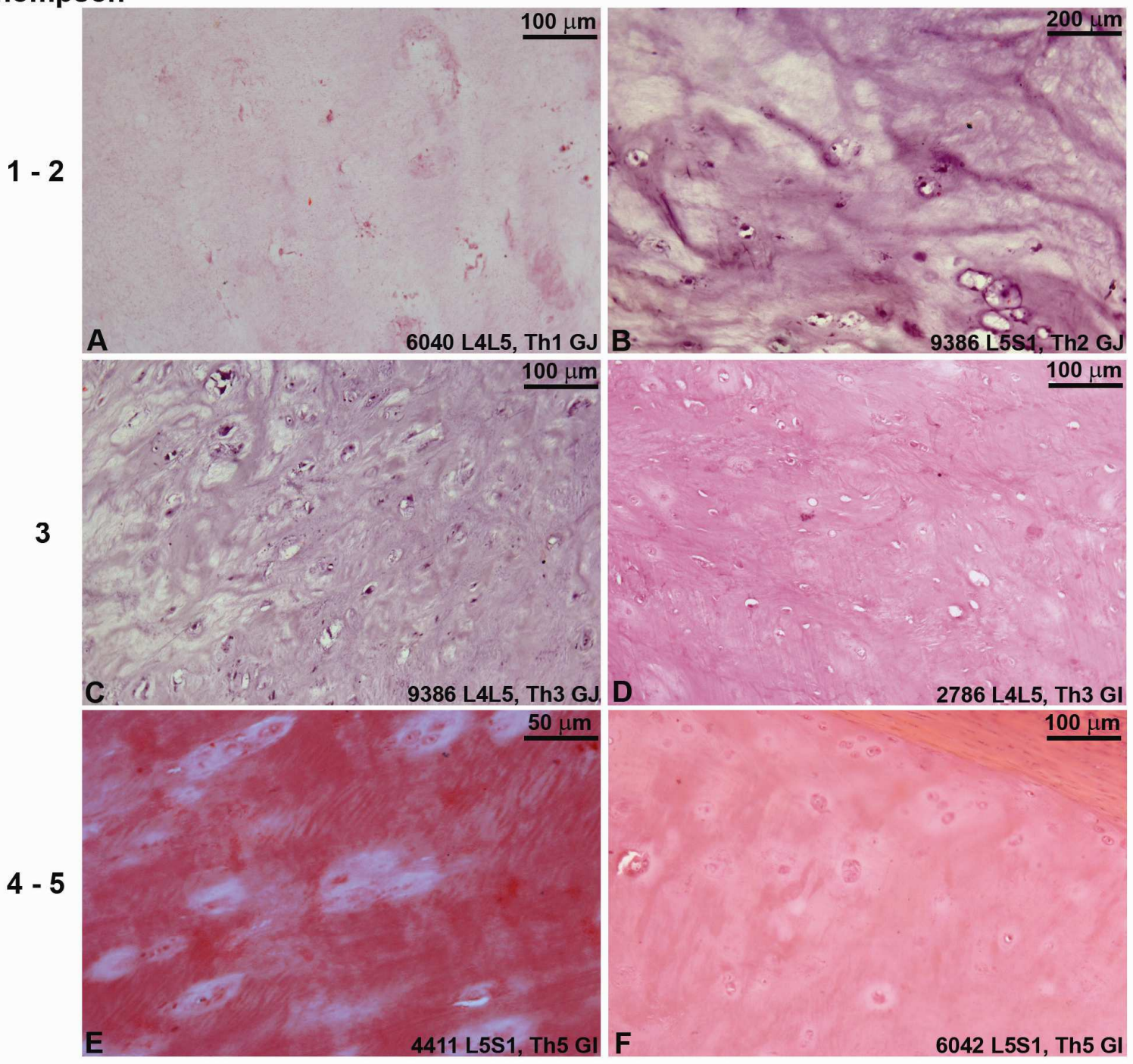

Figura 31 - Espécimes lombares, região central. Agrupamento conforme a classificação de Thompson. Os espécimes tenderam a se agrupar conforme o grau de degeneração e não necessariamente a idade: espécimes de $\underline{\mathbf{G}}$ e $\underline{\mathbf{G I}}$ são similares quando dentro de uma mesma classificação ( $\underline{\mathbf{3 1 C}}$ e $\underline{\mathbf{D}})$. De um modo geral, $\underline{\mathbf{G J}}$ apresentou um núcleo menos denso ( $\underline{\mathbf{3 1 B}}$ e $\underline{\mathbf{3 1 C}}$ ). Demonstra-se a progressão de um núcleo frouxo, com poucos condrócitos ( $\underline{\text { 31A }}, \underline{\text { 31B }})$ para um padrão de matriz extracelular densa ( $\underline{\text { 31C, }} \underline{\text { 31D }})$ e padrão francamente cartilagíneo (31E, $\underline{31 F})$. 

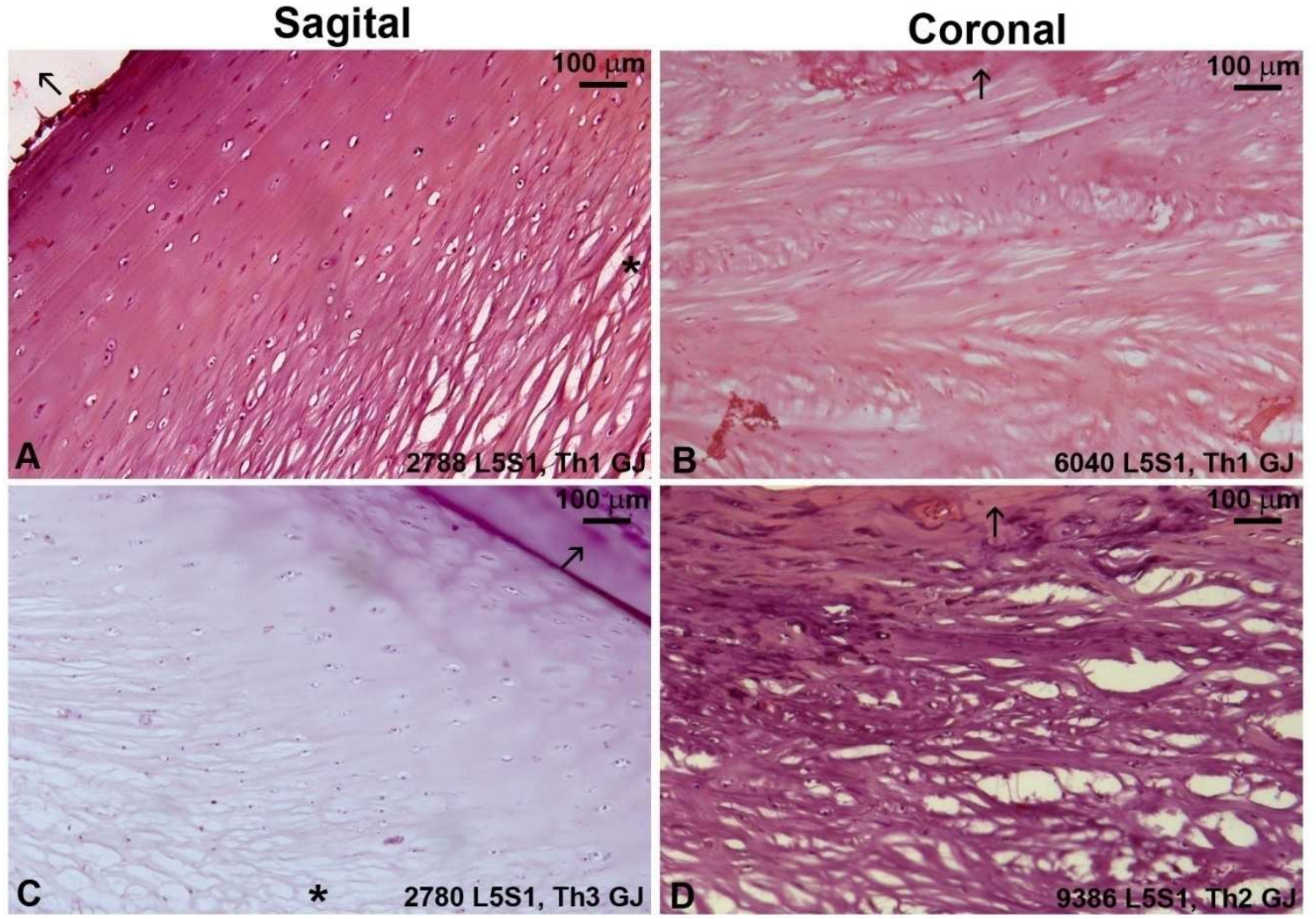

Figura 32 - Espécimes lombares, região posterior do anel fibroso, espécimes com baixo grau de degeneração. Setas indicam a direção da placa vertebral e asteriscos nas secções sagitais demonstram a direção anterior. Componente longitudinal é mais uma vez o mais importante neste setor ( $\underline{\mathbf{3 2 A}}$ e $\underline{\mathbf{3 2 C}}$ ). Nas seç̧ões coronais, foi visualizado um componente oblíquo, quase transversal, que não se verificou no segmento cervical e que assemelha-se ao encontrado no setor anterior dos AF do segmento lombar ( $\underline{32 B}$ e 32D).

Os espécimes com elevado grau de degeneração demonstraram alterações morfológicas importantes (igura 33), ainda que sem perda completa do padrão de feixes alternantes mesmo alguns espécimes Thompson 5 preservaram esta estrutura (Figura 33D). Aglomerados de condrócitos foram demonstrados também neste setor (Figura 33D). 

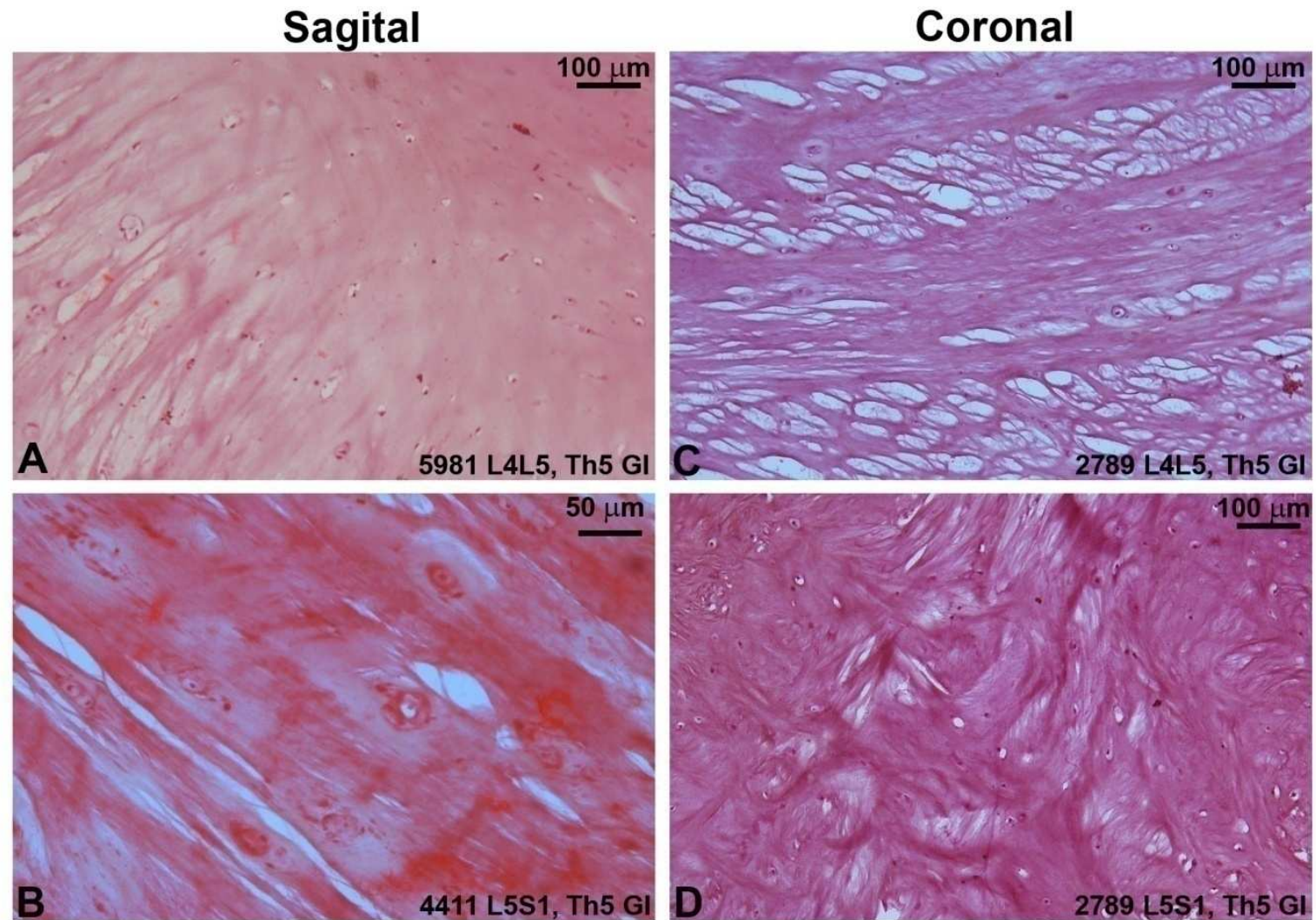

Figura 33 - Espécimes lombares, região posterior do anel fibroso, espécimes com alto grau de degeneração, todos pertencentes a Gl. Adensamento da matriz do AF visível em todas as imagens; ainda assim, não há perda completa do padrão de feixes como verificado no segmento cervical ( $\underline{33 \mathrm{C}})$.

Quando considerados em conjunto, as alterações degenerativas no segmento lombar são peculiares em relação às do segmento cervical: embora tenha se verificado o mesmo espessamento de matriz e proliferação da placa vertebral, o tecido do AF nunca adquiriu características francamente cartilagíneas e hialinas (Figura 34). A presença de grupos de condrócitos foi comum e até mesmo vasos no interior da região posterior do AF (Figura 34E) em duas ocasiões, ambas em indivíduos de Gl. Tal achado foi ainda mais significativo por se localizar adjacente a uma fissura horizontal no AF. 


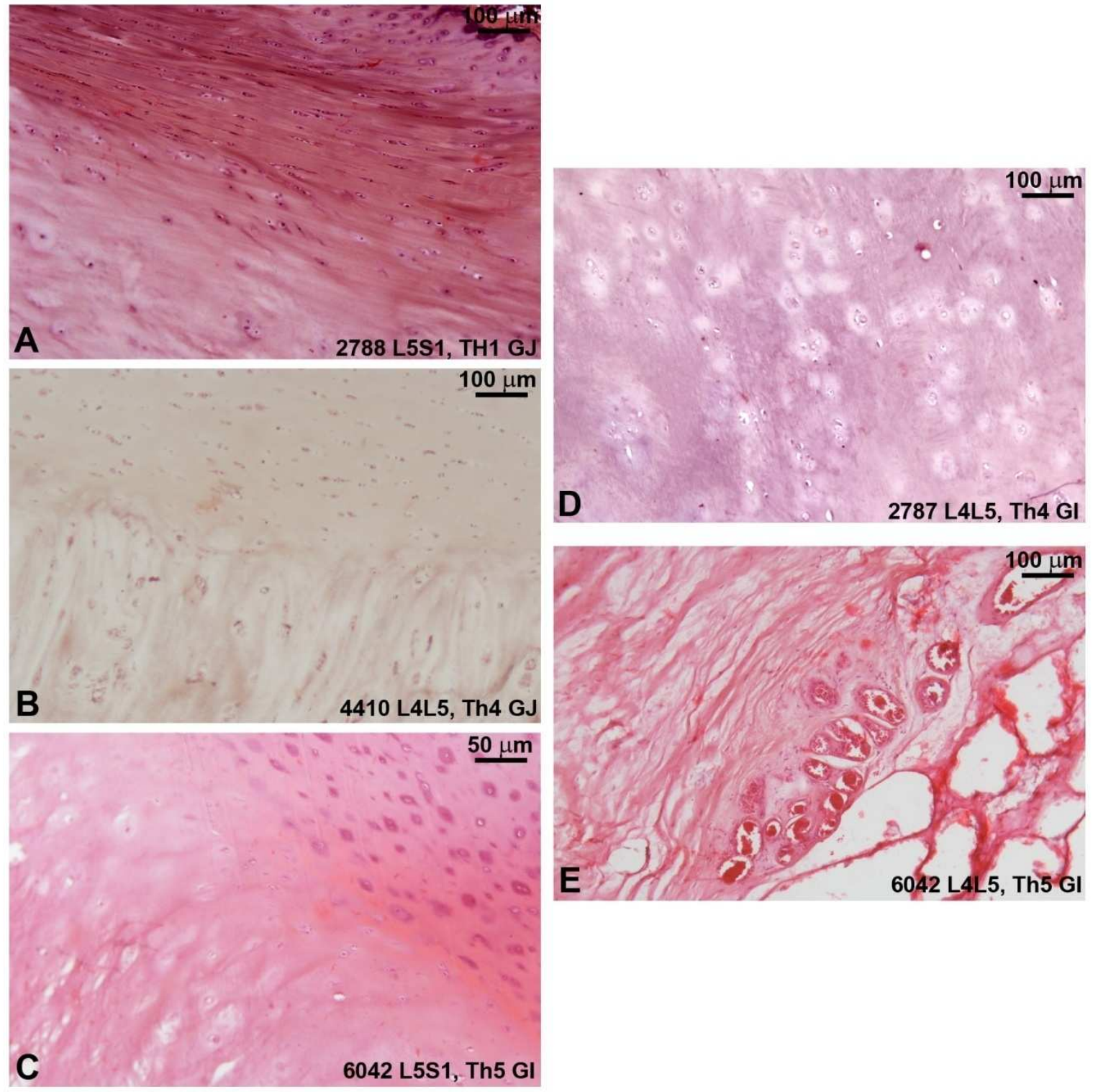

Figura 34 - Espécimes lombares, alterações degenerativas clássicas. A progressão das modificações degenerativas da placa vertebral no segmento lombar está demonstrada em 34A-C: ainda que haja um aumento de sua espessura, seu padrão cartilagíneo não ocupa todo o espaço das fibras do anel mesmo em espécimes com elevado grau de degeneração. Verificou-se também a presença de grupos de condrócitos (34D) e até a presença de vasos na região posterior do AF ( $\underline{35 E})$. 


\subsubsection{Feixes conjuntivos - Picro-Sirius}

Assim como nos discos do segmento cervical, a coloração de Picro-Sirius demonstrou com sucesso o arcabouço conjuntivo no segmento lombar. A organização lamelar na região anterior do AF verificada através de HE foi novamente evidenciada, com predomínio de fibras longitudinais nos setores mais superficiais e fibras oblíquas nos profundos (Figura 35). Novamente se demonstrou a presença não de fibras transversais, mas oblíquas no AF (Figura 35C). Resultados conflitantes doram verificados na análise de refringência: enquanto que secções sagitais sugeriram um predomínio de colágeno II com componentes menores de colágenos I e III, as secções coronais por vezes demonstraram presença quase exclusiva de colágeno tipo I (Figura 35D).

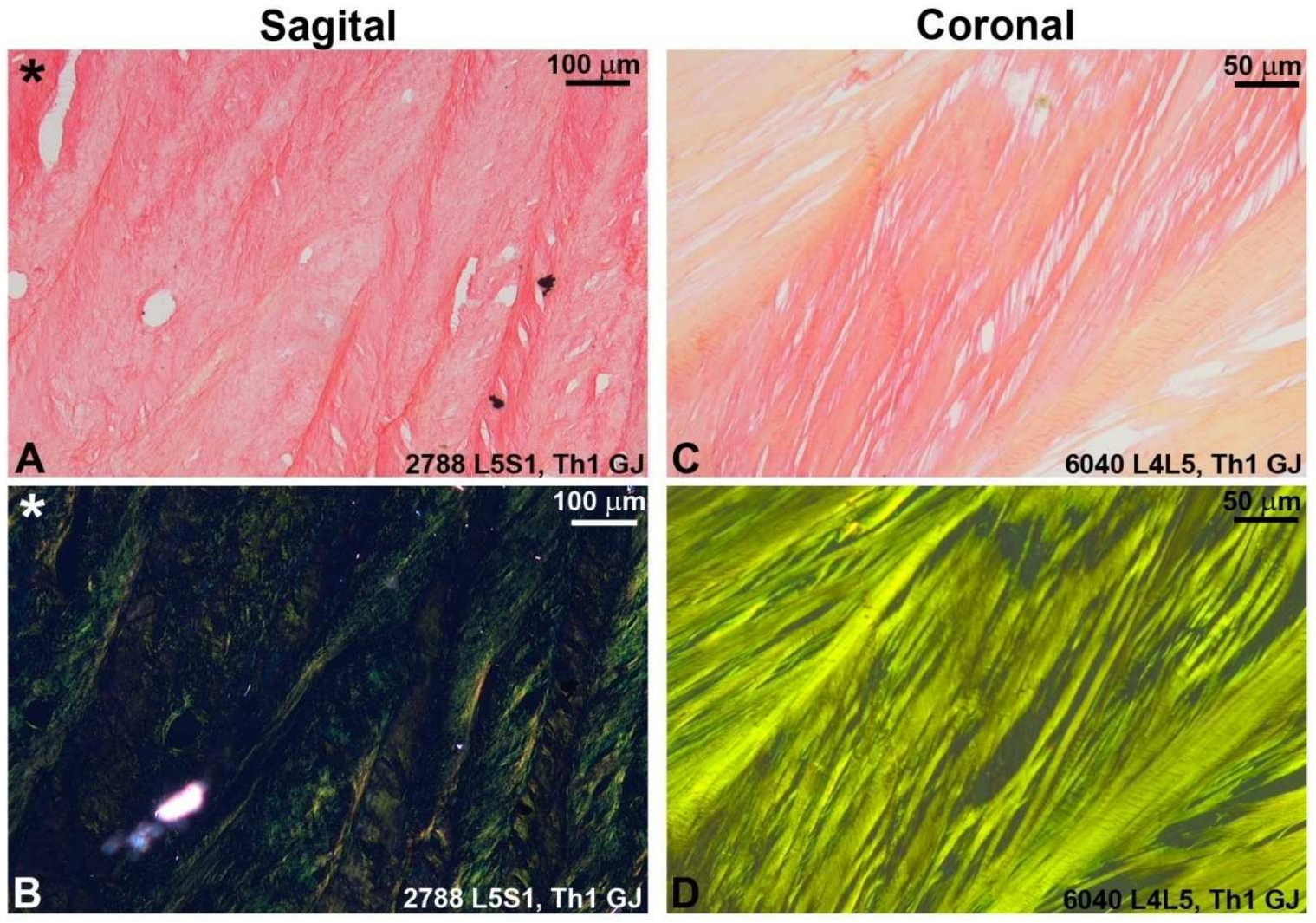

Figura 35 - Espécimes lombares, região anterior do anel fibroso, espécimes com baixo grau de degeneração. Asteriscos nas seç̧ões sagitais denotam a direção anterior. Alternância de lamelas demonstrada nas secções sagitais $(\underline{\mathbf{A}, \mathbf{B}})$ e coronais com alternância oblíqua e não perfeitamente ortogonal $(\underline{\mathbf{C}, \mathbf{D}})$. Análise por luz polarizada com resultados conflitantes: secção sagital sugere predomínio de colágeno tipo II e componentes menores de tipos I e III; já o espécime em orientação coronal (ㅁ) sugere quase exclusividade de colágeno tipo I. Luz normal $(\underline{\mathbf{A}, \mathbf{C}})$ e polarizada $(\underline{\mathbf{B}, \mathbf{D}})$. 
Os espécimes mais degenerados não perderam sua organização em lamelas mesmo nos graus extremos de Thompson (Figura 36). Ainda que a presence de condrócitos fosse exuberante, as lamelas sempre estiveram visíveis (Figura 36A e $\underline{36 C}$ ), sendo que a refringência sugere uma diminuição acentuada do conteúdo global de colágeno (Figura 36B) e predomínio de colágeno tipo II (Figura 36D).

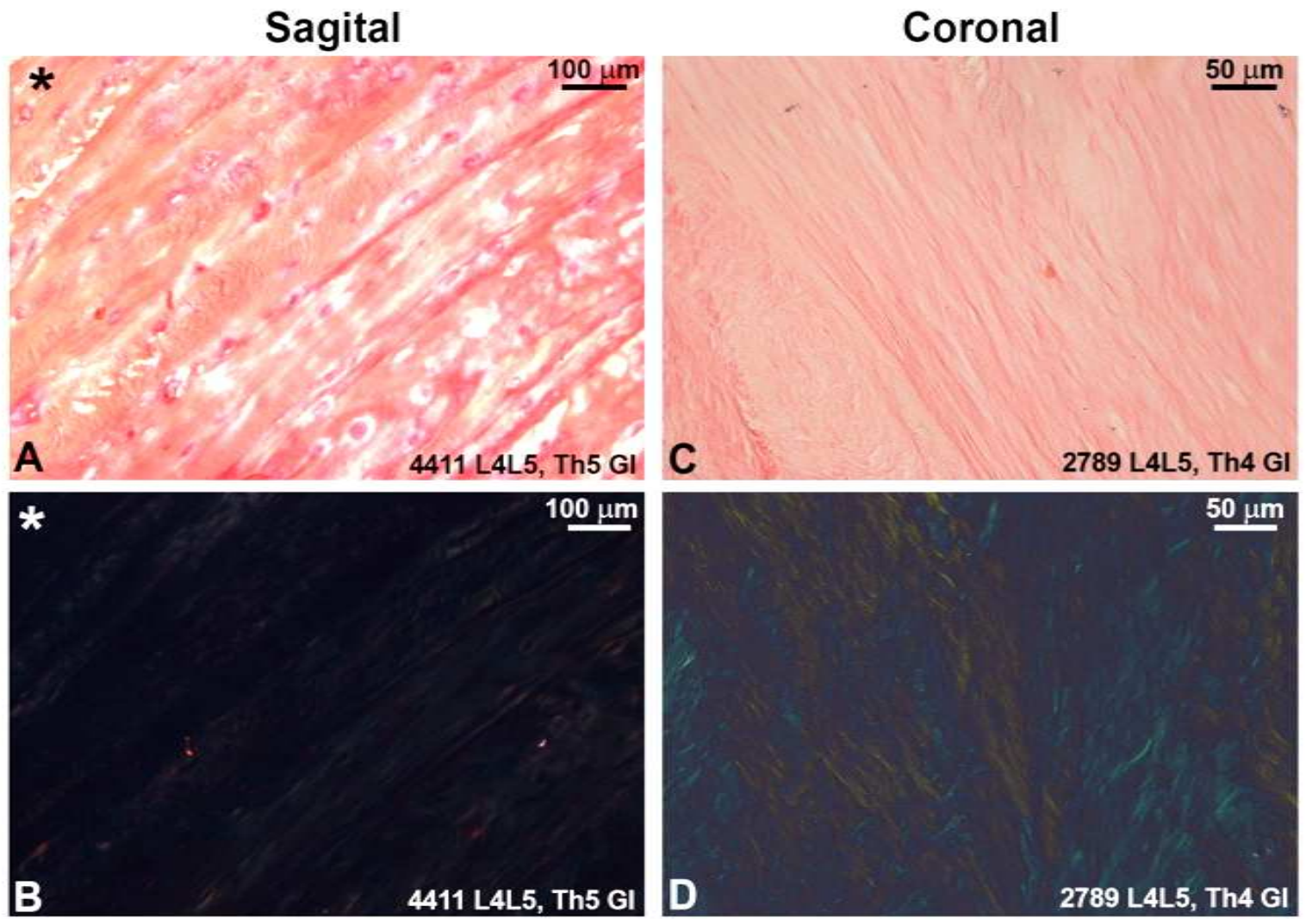

Figura 36 - Espécimes lombares, região anterior do anel fibroso, espécimes com alto grau de degeneração. Asteriscos nas secções sagitais denotam a direção anterior. Apesar da extensa modificação do padrão lamelar, este ainda é visível em $\underline{\mathbf{3 6 A}}$ e $\underline{\mathbf{3 6 C}}$. Análise de refringência revela menor componente colágeno $(\underline{36 B}, \mathbf{D})$ e predomínio de colágeno tipo II. Luz normal $(\underline{\mathbf{A}, \mathbf{C}})$ e polarizada $(\underline{\mathbf{B}, \mathbf{D}})$.

A região central dos discos lombares manteve um núcleo identificável conforme já verificado na análise das secções coradas com HE. Ficou evidente nas secções coradas por Picro-Sirius a matriz extracelular frouxa nos espécimes jovens, com um padrao de refringência sugerindo predomínio de fibras longas sugestivas de colágeno I (Figura 37). 
Sagital

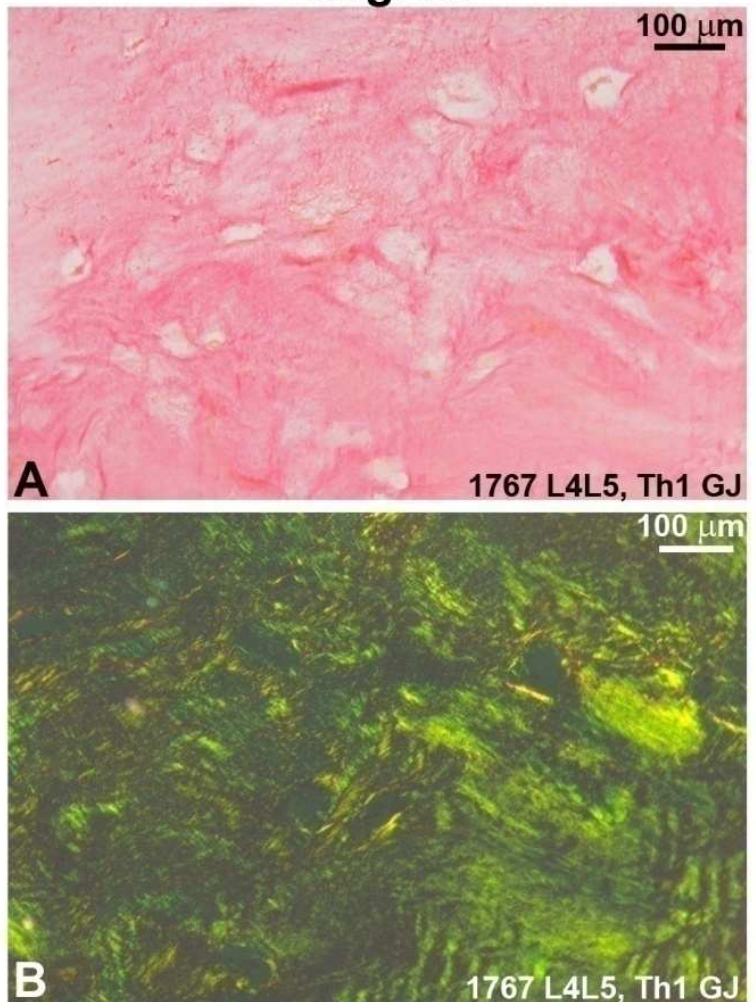

Coronal

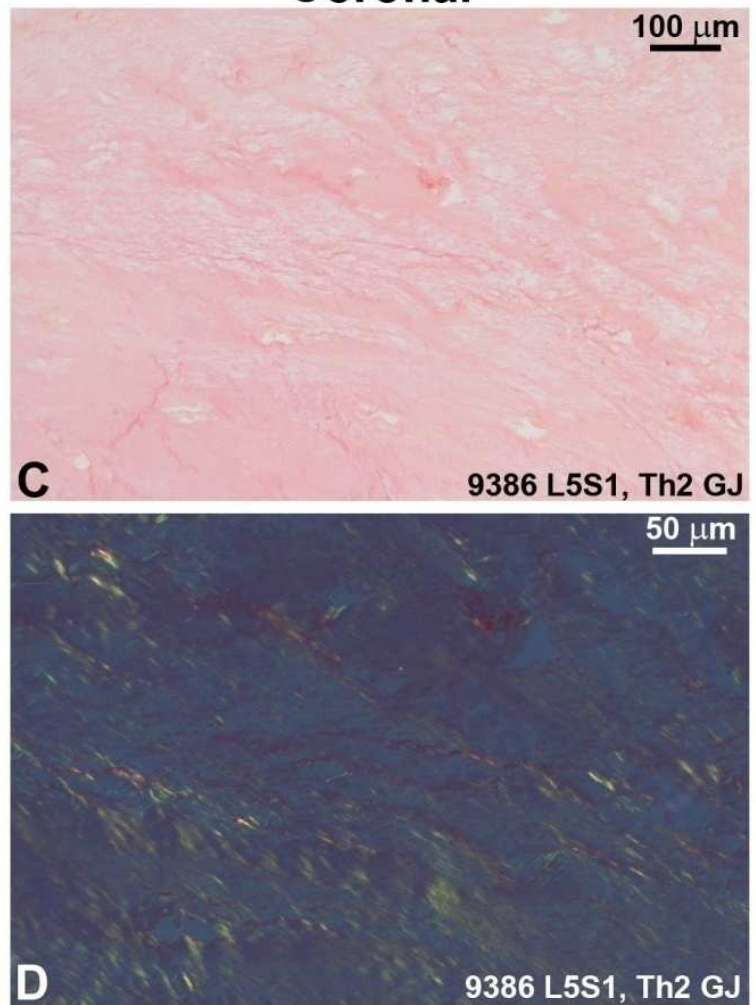

Figura 37 - Espécimes lombares, região central, espécimes com baixo grau de degeneração. Matriz extracelular frouxa e pequeno número de condrócitos nas secções analisadas sob luz normal $(\underline{\mathbf{A}, \mathbf{C}})$. Análise de refringência demonstra predomínio de fibras amareladas e avermelhadas ( $\underline{\mathbf{B}}$ ) com um componente opaco menor $(\underline{\mathbf{D}})$, sugestivas de colágenos tipo I e II, respectivamente.

Quando os núcleos dos espécimes degenerados foram submetidos à técnica de Picro-Sirius, estes ainda se distinguiam claramente do AF (Figura 38). Entretanto, ficou claro o adensamento da matriz, aumento do número de condrócitos e diminuição da intensidade das refringências amarela, verde e vermelha. Não é, por outro lado, simples proliferação da placa vertebral uma vez que esta ainda se distingue facilmente do NP. 
Sagital
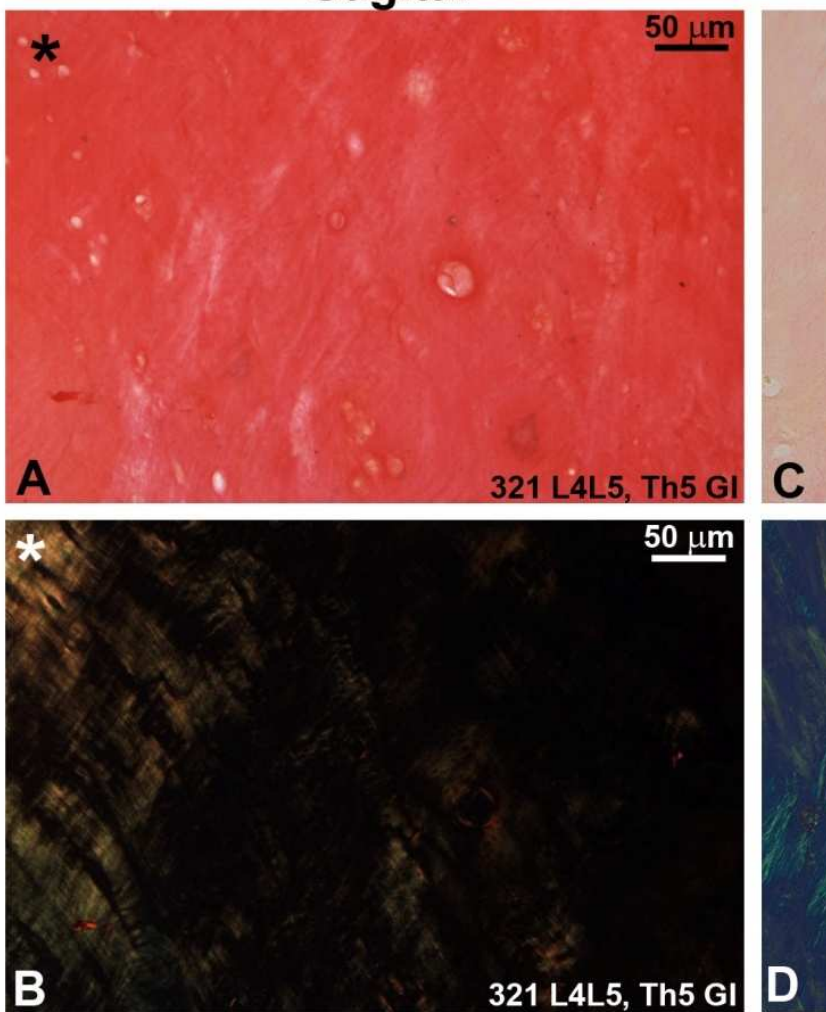

2789 L5S1, Th5 GI

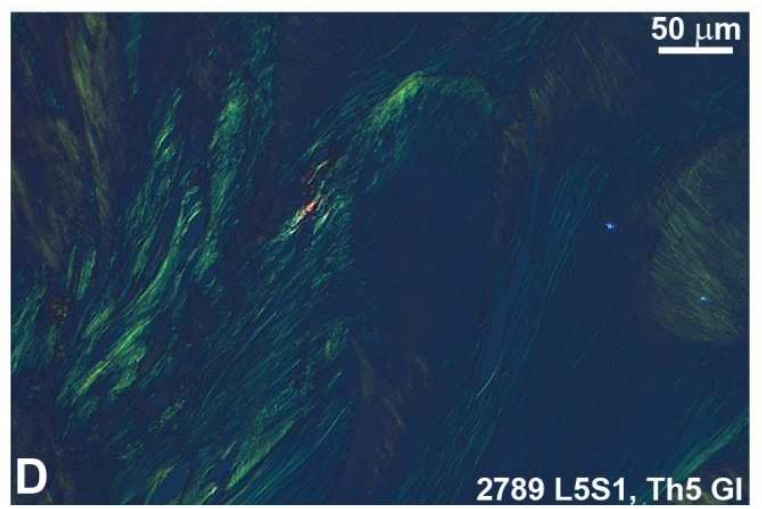

Figura 38 - Espécimes lombares, região central, espécimes com alto grau de degeneração. Adensamento da matriz conjuntiva $(\underline{\mathbf{A}, \mathbf{C}})$ com aumento do número de condrócitos. Concomitantemente, diminuição do componente amarelo e vermelho na análise de polarização $(\underline{\mathbf{B}, \boldsymbol{D}})$. Asteriscos demonstram a região da placa vertebral. Luz normal $(\underline{\mathbf{A}, \boldsymbol{C}})$ e polarizada $(\underline{\mathbf{B}, \mathbf{D}})$.

A análise da região posterior do AF pela técnica de Picro-Sirius reforçou o achado de alternância de lamelas mais pronunciada que no segmento cervical. Na Figura 39, torna-se evidente a alternância destas lamelas; o ângulo entre elas não é perfeitamente ortogonal, sugerindo assim disposição oblíqua. A disposição desta região do AF não é significativamente alterada nos espécimes com maior grau de degeneração, como pode ser visto na Figura $\mathbf{4 0}$. Apesar de um certo adensamento da matriz extracelular, este é o setor em que os espécimes de $\underline{G}$ e GI mais se assemelham. A análise por refringência sugere elevado componente de colágeno tipo I em ambos os grupos (ㅌiguras 39 e $\underline{40}$ ) com participação menor de colágeno tipo III. 
Sagital

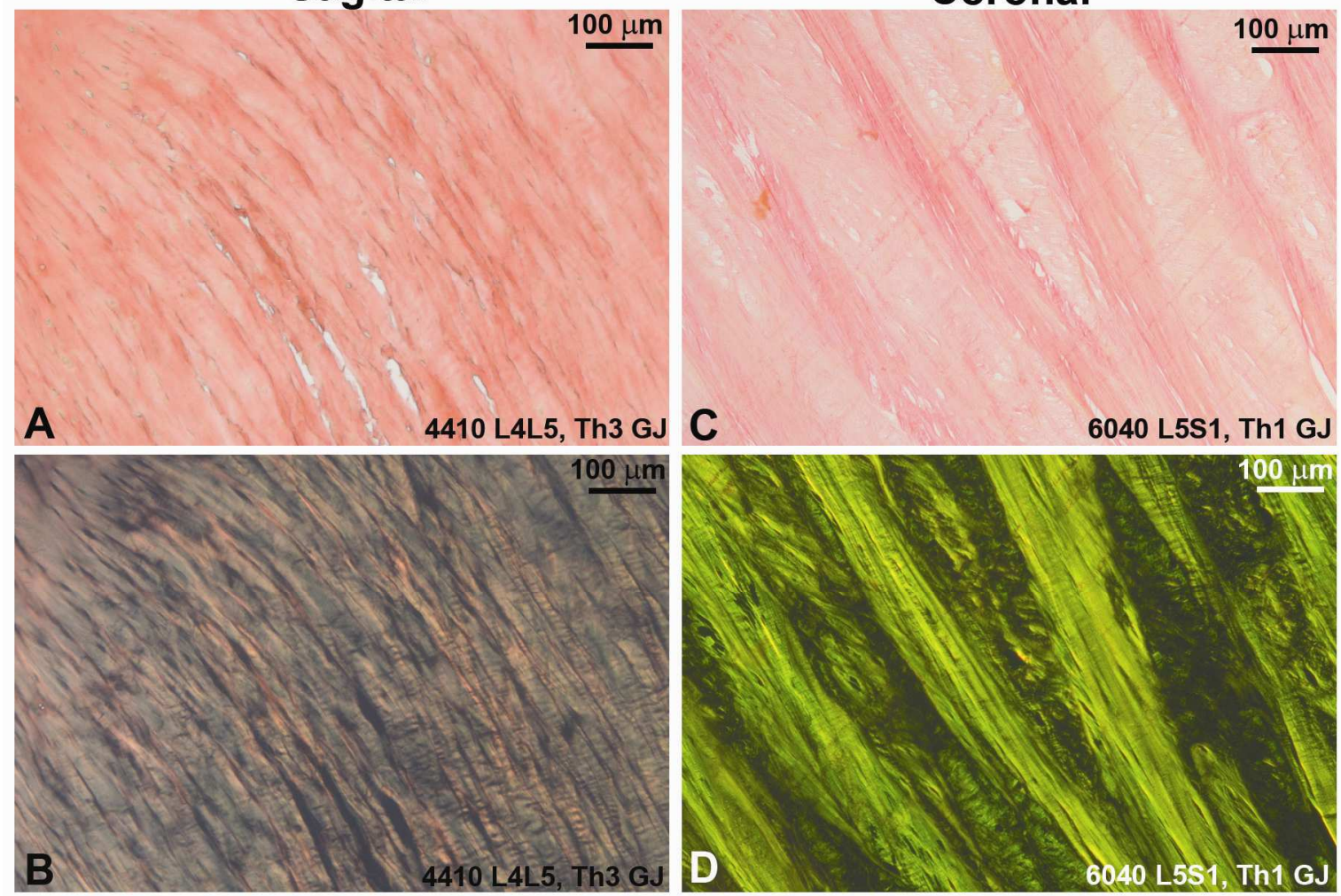

Figura 39 - Espécimes lombares com baixo grau de degeneração, região posterior do AF, coloração Picro-Sirius. Luz normal $(\underline{\mathbf{A}, \mathbf{C}})$ e polarizada $(\underline{\mathbf{B}, \mathbf{D}})$. Feixes predominantemente longitudinais são vistos nas secções sagitais $(\underline{A}, \mathbf{B})$ enquanto que alguma alternância é sugerida nas secções coronais; observou-se que o ângulo entre estas lamelas não é ortogonal (ㅁ). Predomínio de fibras amarelo-avermelhadas na análise de refringência. 
Sagital

A
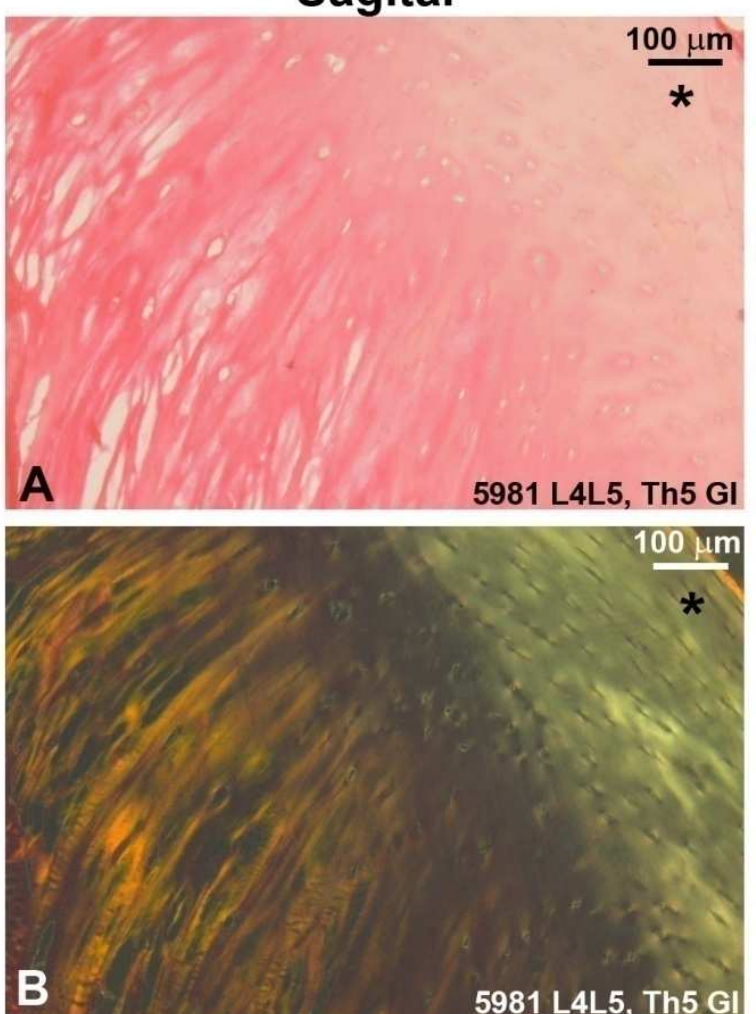

5981 L4L5, Th5 G
Coronal
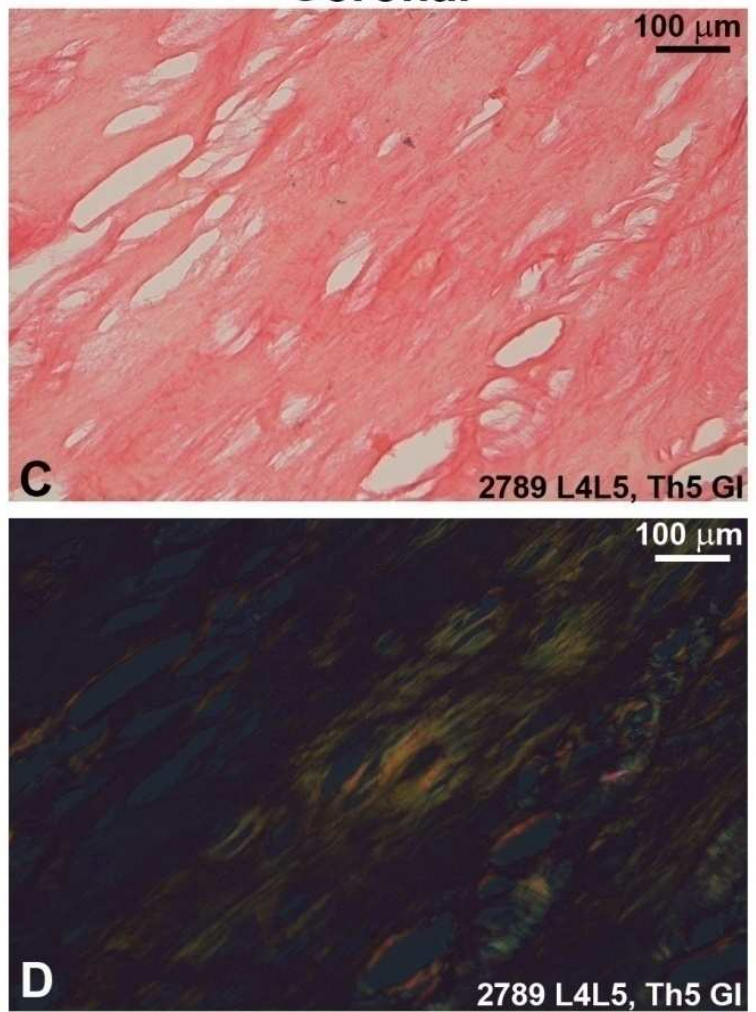

Figura 40 - Espécimes lombares com elevado grau de degeneração, região posterior do $A F$, coloração Picro-Sirius. Luz normal $(\underline{\mathbf{A}, \mathbf{C}})$ e polarizada $(\underline{\mathbf{B}, \mathbf{D}})$. Apesar de algum adensamento, a estrutura de feixes está mantida $(\underline{\mathbf{A}})$, com alternância similar à verificada nos espécimes com baixo grau de degeneração (므). Predomínio de fibras vermelhas na seç̧ão sagital (ㅁ) e coronal (므). 


\subsubsection{Fibras elásticas}

As fibras do sistema elástico foram adeaquadamente demonstradas também no segmento lombar através das técnicas de Verhoeff e Weigert. Na região anterior do AF, ficou demonstrada a abundância de fibras elásticas maduras e elaunínicas nos espécimes menos degenerados de GJ (Figura 41), alinhadas em paralelo com as fibras conjuntivas do AF.

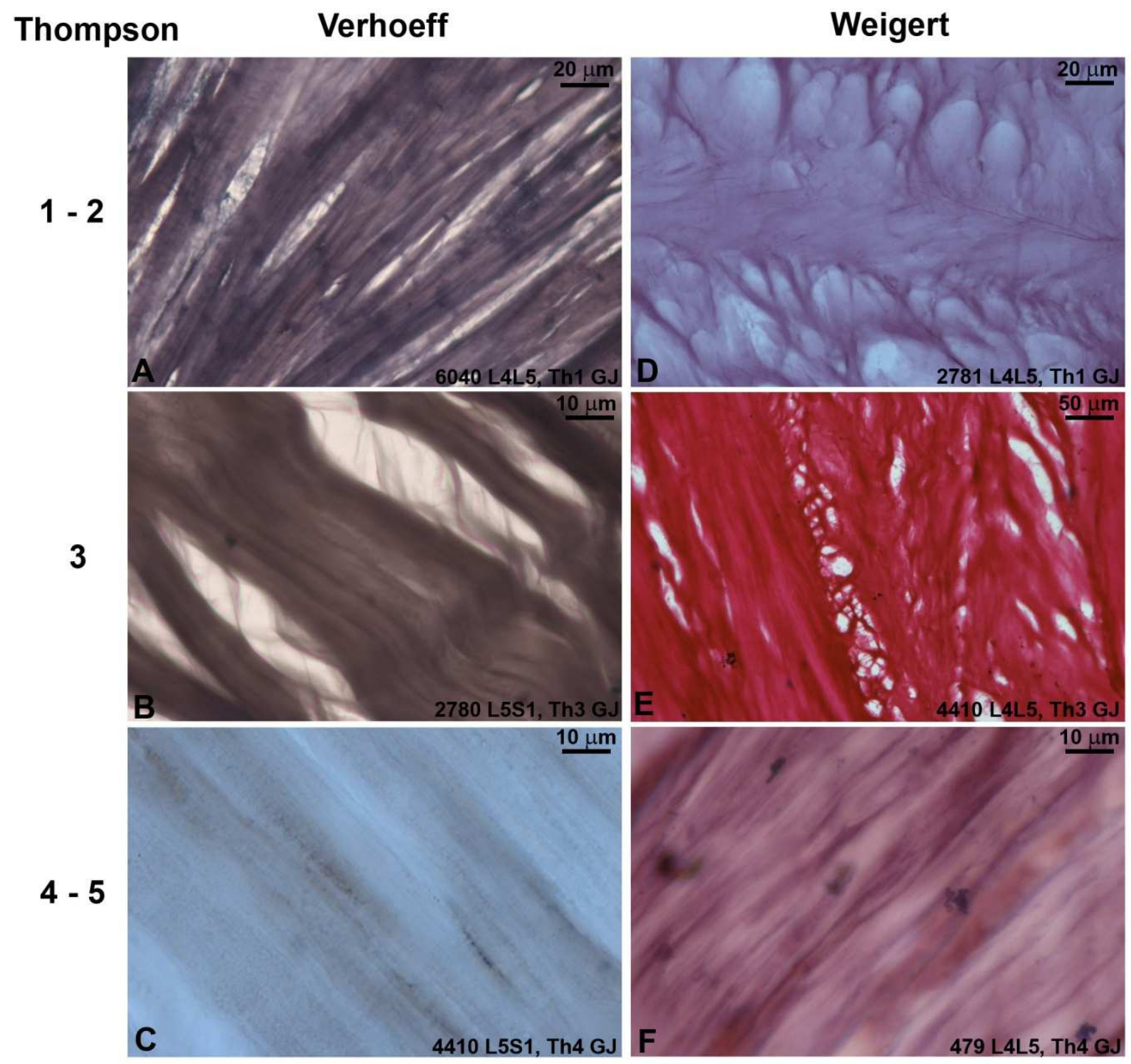

Figura 41 - Discos lombares, $\underline{\mathbf{G J}}$, região anterior do AF, colorações de Verhoeff $(\underline{\mathbf{A}-\mathbf{C}})$ e Weigert (D-F), agrupados conforme grau de Thompson. Fibras elásticas e elaunínicas são abundantes até os graus mais elevados de degeneração; em Thompson 4-5, a quantidade de elásticas maduras diminui enquanto ainda Weigert ainda demonstra grande número de fibras. 
A quantidade de elásticas maduras diminuiu visivelmente nos espécimes mais degenerados de GJ; o fato de Weigert ainda demonstrar um grande número de fibras sugere que estas são compostas predominantemente por fibras elaunínicas (igura 41).

Este mesmo setor foi significativamente alterado nos espécimes de $\underline{\text { Gl}}$. Também se percebeu uma diminuição no número de fibras elásticas com o aumento do grau de Thompson (Figura 42). Entretanto, mesmo nos espécimes Thompson 1-2, a quantidade de fibras é bem menor que nos espécimes $\underline{\text { Gl}}$. Além disso, a diminuição afetou igualmente fibras elásticas maduras e elaunínicas.

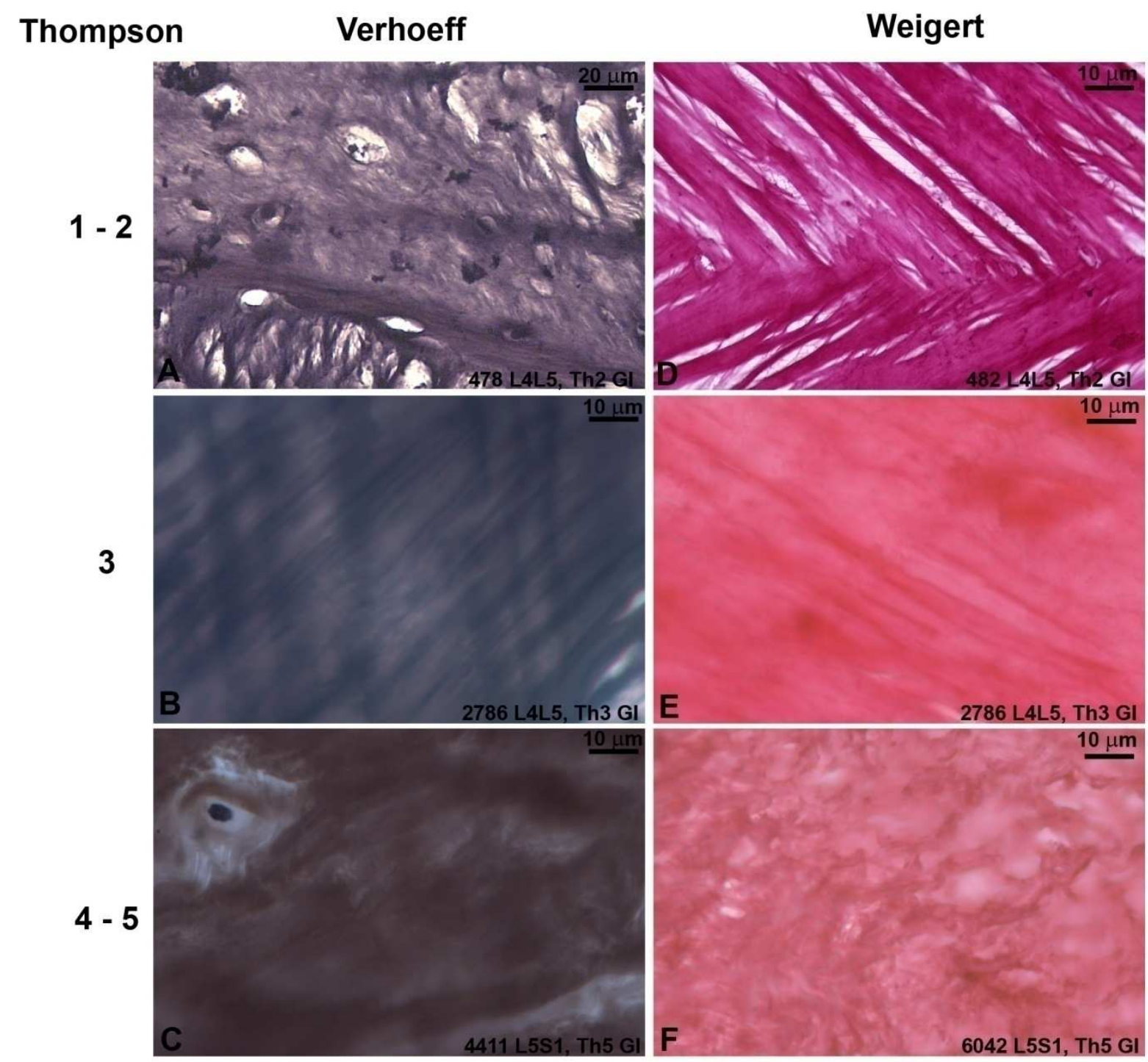

Figura 42 - Discos lombares, $\underline{\text { Gl, }}$, região anterior do AF, colorações de Verhoeff $(\underline{\mathbf{A}-\mathbf{C}})$ e Weigert $(\underline{\mathbf{D}-\mathbf{F}})$, agrupados conforme grau de Thompson. A quantidade de fibras elásticas é bem menor que nos espécimes de GJ (Figura 41) e a sua diminuição nos espécimes mais degenerados se faz de maneira similar em Verhoeff e Weigert. 
Na região central dos discos lombares, ficou demonstrado mesmo em $\underline{\text { GJ }}$ uma escassez relativa de fibras elásticas (Figura 43). Mesmo nos espécimes pouco degenerados, com matriz extracelular frouxa, as fibras elásticas foram virtualmente inexistentes (Figura 43A e 43D). As poucas fibras visualizadas não estavam dispostas em nenhuma orientação particular, ao contrário daquelas do AF (Figura 41).

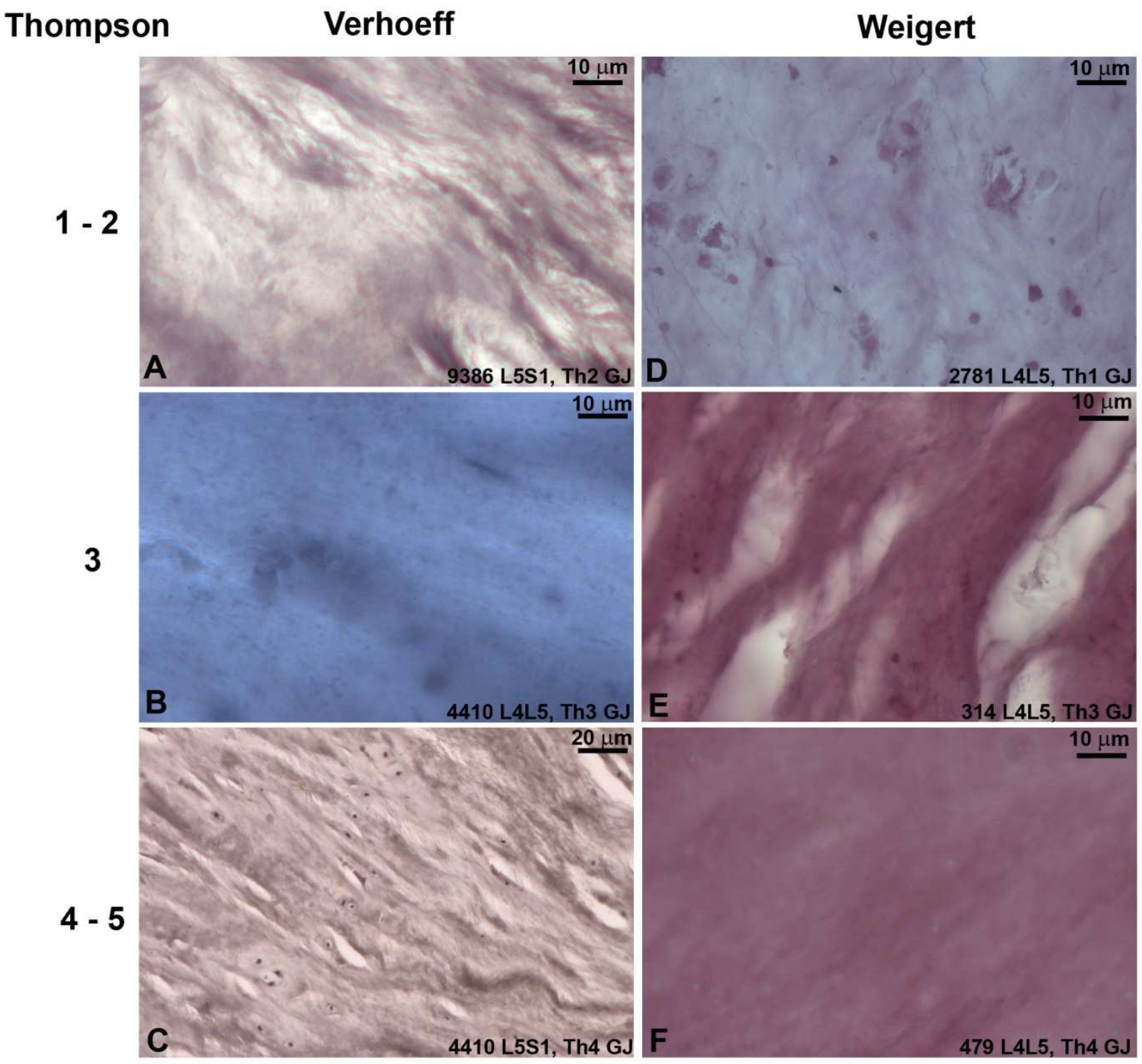

Figura $\mathbf{4 3}$ - Discos lombares, $\underline{\mathbf{G J}}$, região central do disco, colorações de Verhoeff ( $\underline{\mathbf{A}-\mathbf{C}}$ ) e Weigert (DF), agrupados conforme grau de Thompson. Fibras elásticas e elaunínicas são muito mais escassas no NP que no AF; estas não dispostas em nenhuma orientação em particular e não apresentam variação significativa de acordo com o grau de Thompson. 
Os espécimes de GI não demonstraram quantidade significativa de fibras elásticas na região correspondente ao NP (Figura 44). Esta região demonstrou o adensamento já verificado por outras técnicas, porém sem modificação no padrão de fibras elásticas.

\section{Thompson}

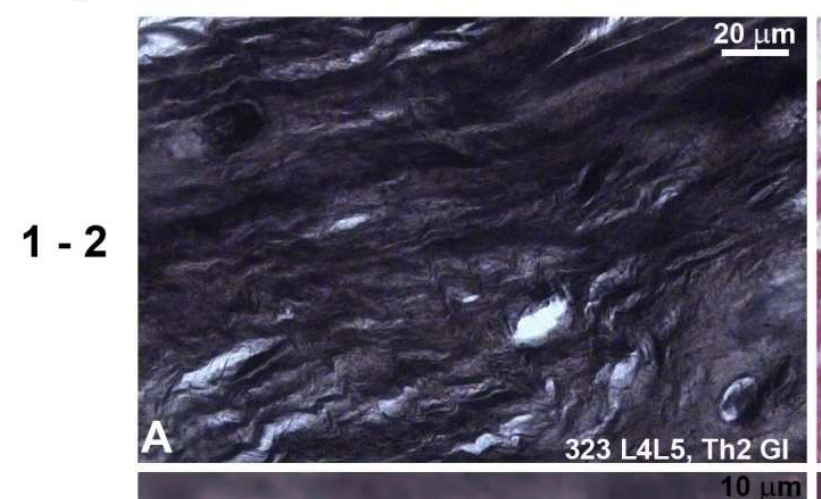

3
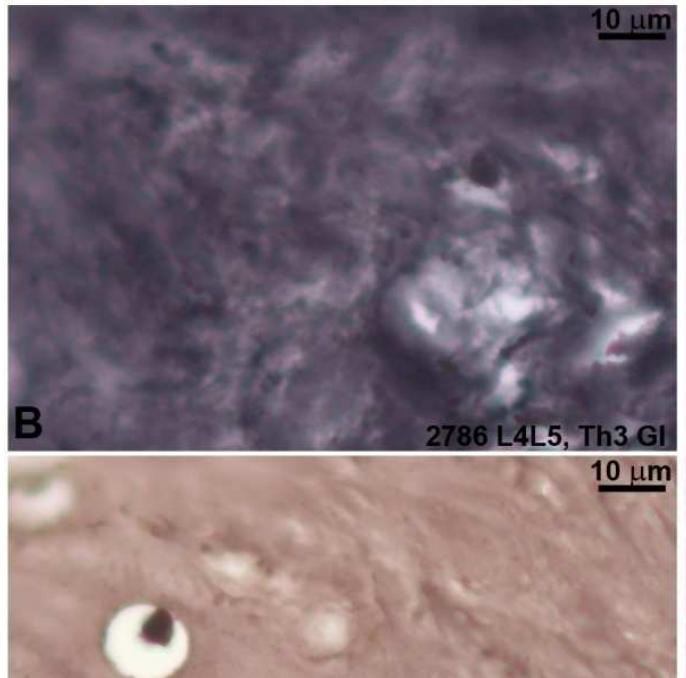

$4-5$

C
Verhoeff

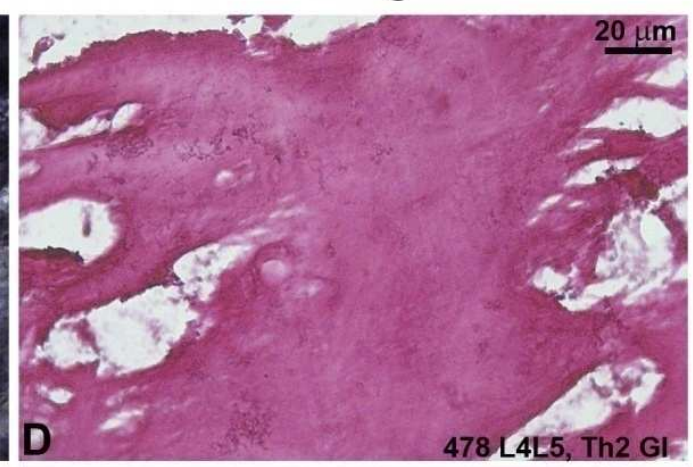

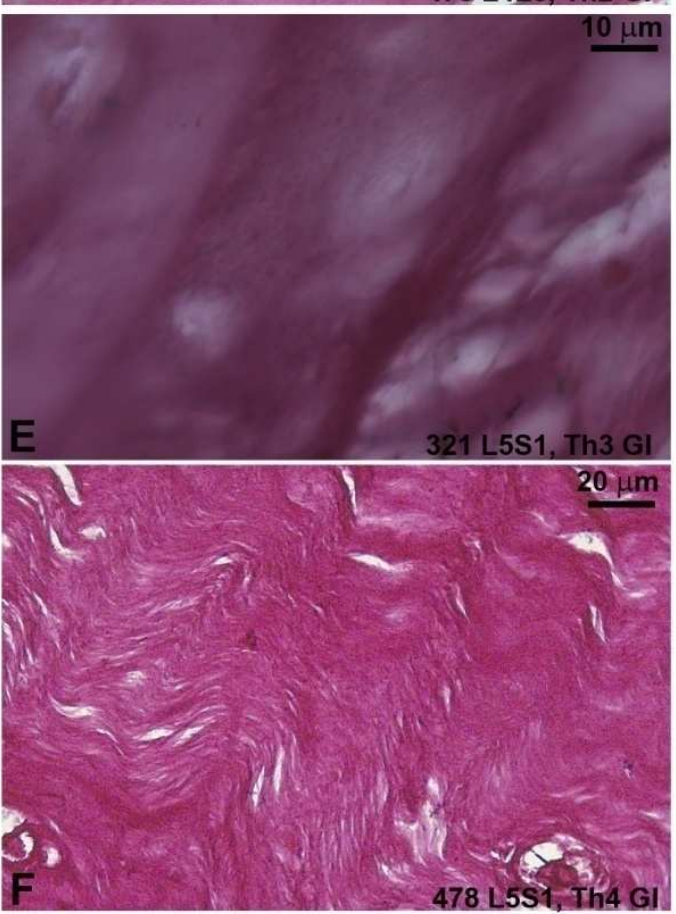

Figura 44 - Discos lombares, GI, região central do disco, colorações de Verhoeff ( $\underline{\mathbf{A}-\mathbf{C}})$ e Weigert (DE), agrupados conforme grau de Thompson. Não há fibras elásticas em quantidade apreciável em nenhuma das figuras. $O$ adensamento da matriz extracelular fica evidente particularmente em $\underline{\mathbf{4 A A}}$ e $\underline{\mathbf{4 4 F}}$, além da presença de caracerísticas cartilagíneas em $\underline{\mathbf{4 4 C}}$. 
A região posterior do AF dos espécimes jovens apresentou, como na região anterior, abundância de fibras elásticas, orientadas em paralelo com as fibras de conjuntivo do AF (Figura 45). A diminuição nos espécimes degenerados, entretanto, foi muito mais completa que na região anterior do AF; espécimes com grau 4-5 de degeneração praticamente não apresentavam fibras elásticas (Figura 45C e 45F), sem a discrepância entre elásticas e elaunínicas vista na região anterior.

Thompson

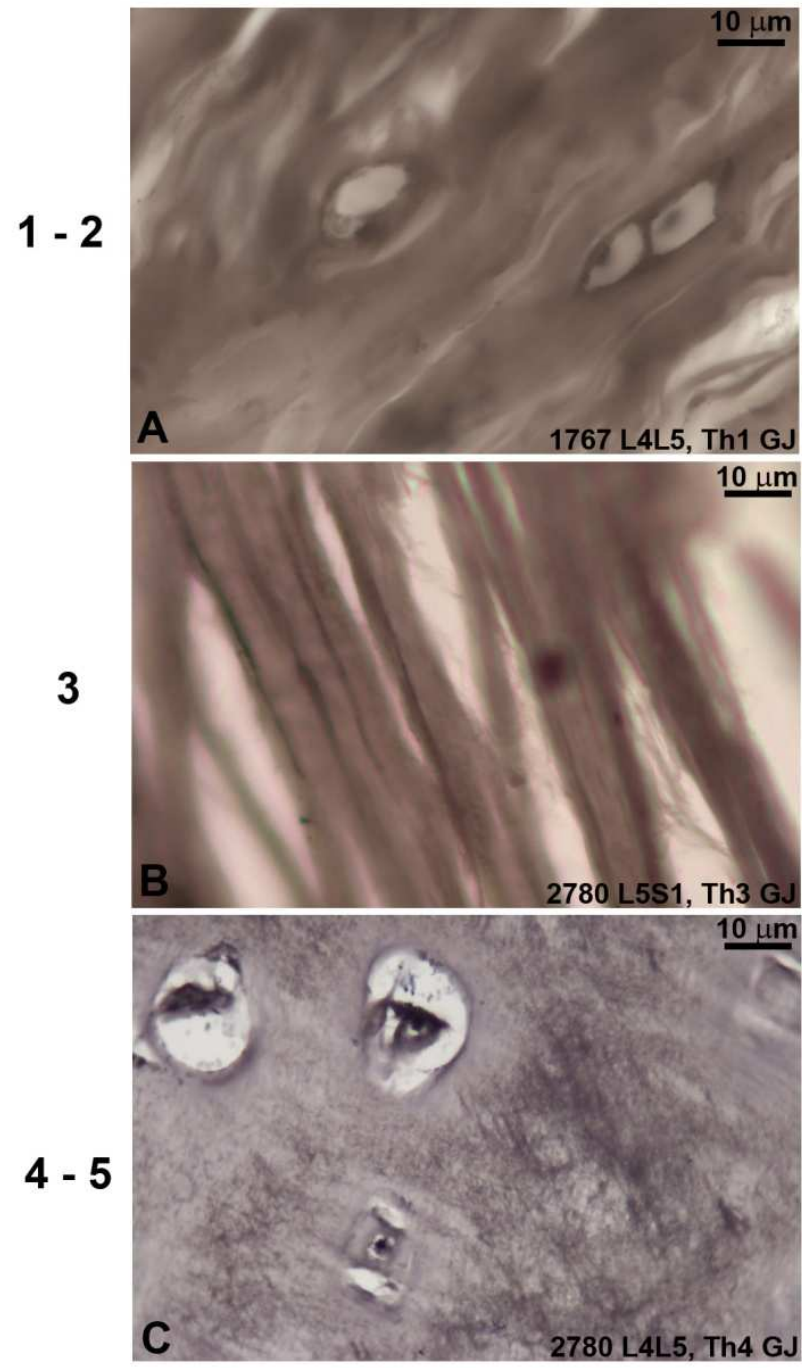

Weigert

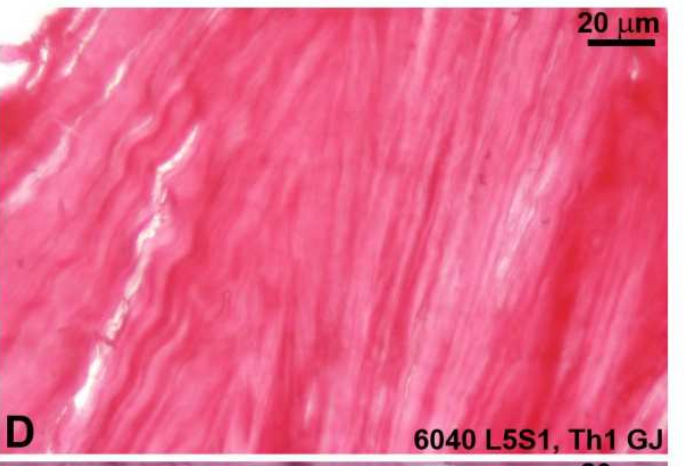

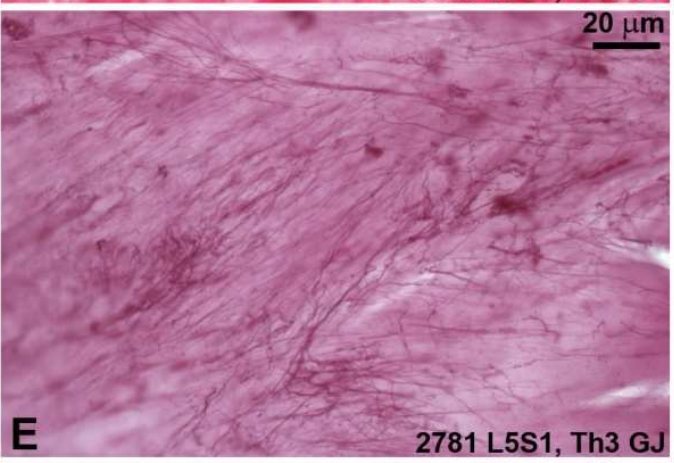

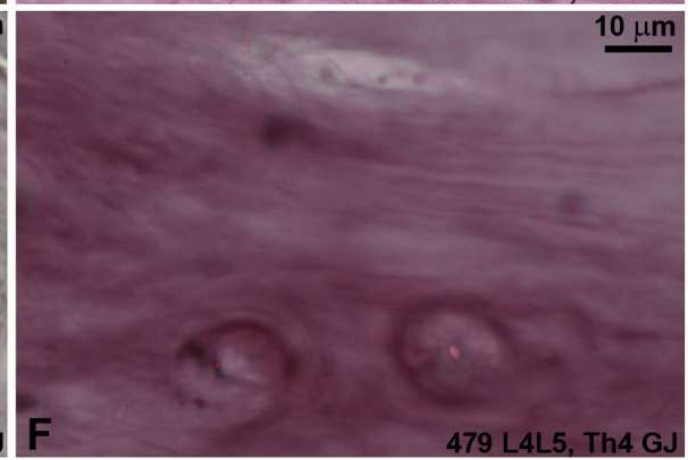

$\underline{\text { Figura } 45}$ - Discos lombares, $\underline{\mathbf{G}}$, região posterior do AF, colorações de Verhoeff $(\underline{\mathbf{A}-\mathbf{C}})$ e Weigert $(\underline{\mathbf{D}-\mathbf{F}})$, agrupados conforme grau de Thompson. Fibras elásticas e elaunínicas presentes em abundância nos graus menos degenerados, em paralelo com as fibras de conjuntivo. Espécimes 4-5 de Thompson com quantidade bem menor de elásticas em ambas as colorações. 
A quantidade de fibras elásticas na região posterior do AF nos espécimes de $\underline{\text { GI }}$ também diminuiu em relação a $\underline{\mathbf{G J}}$. Entretanto, ainda se visualizou fibras elásticas em quantidade similar naqueles exemplares com graus menores de degeneração (Figura 46). Particularmente nos espécimes Thompson 3, o aspecto foi semelhante aos Thompson 3 de GJ (Figuras 45B e $\underline{46 B}$ ).

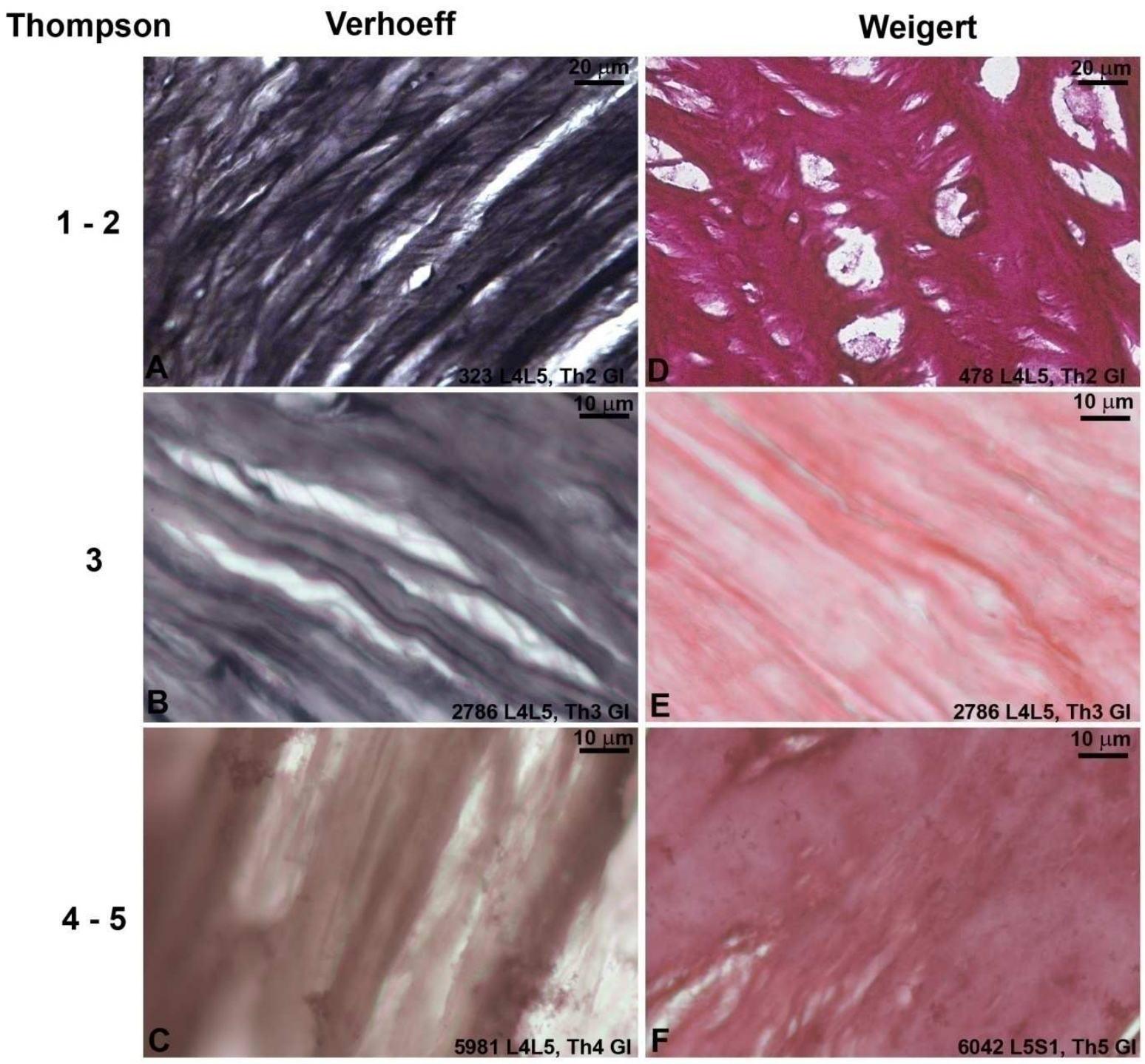

Figura $4 \mathbf{6}$ - Discos lombares, $\underline{\text { Gl, }}$, região posterior do AF, colorações de Verhoeff $(\underline{\mathbf{A}-\mathbf{C}})$ e Weigert $(\underline{\mathbf{D}-\mathbf{F}})$, agrupados conforme grau de Thompson. Menor quantidade de fibras em relação a $\underline{\mathbf{G J}}$, mas ainda uma quantidade relativamente semelhante nos espécimes pouco degenerados; comparar com Figura 45. 


\subsection{Microscopia eletrônica de varredura (MEV)}

O estudo por MEV da superfície de corte do disco intervertebral demonstrou de maneira inequívoca a organização tridimensional do disco intervertebral. Os espécimes cervicais jovens caracterizaram-se por sua estrutura frouxa de lamelas alternantes na região anterior do AF (Figura 47). Ao contrário da avaliação macroscópica e por microscopia de luz, na avaliação por MEV sempre se conseguiu distinguir o AF de um remanescente de NP (Figuras $\underline{47 A}$ e $47 \mathrm{C})$. Este foi demonstrado sem a organização lamelar e retraído, possivelmente em virtude da desidratação a que foram submetidos estes espécimes para MEV combinada com o maior teor de água do NP em relação ao AF.
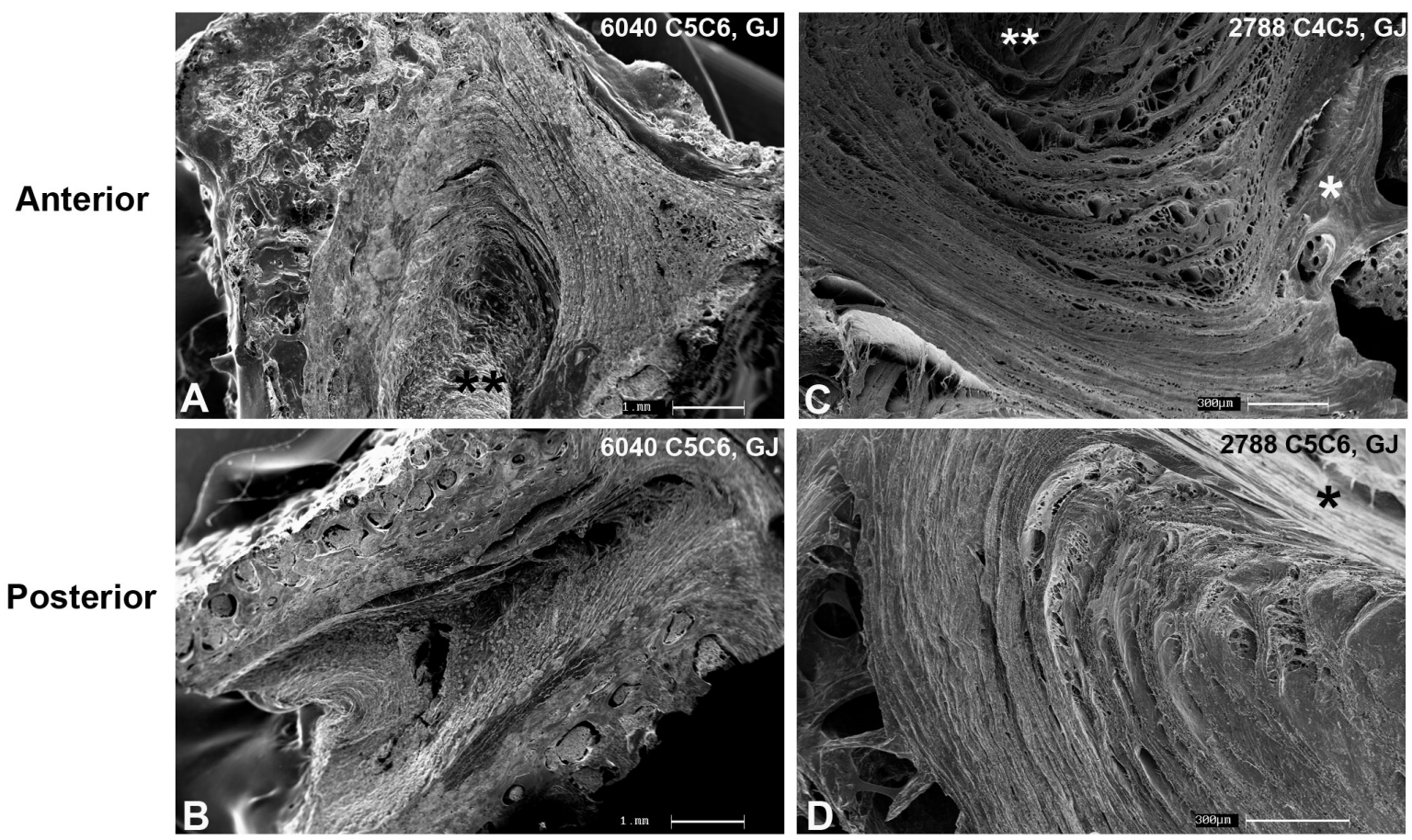

Figura 47 - Discos cervicais, GJ, microscopia eletrônica de varredura. Cortes sagitais, setores anterior e posterior. Estrutura de lamelas alternantes na região anterior do $\mathrm{AF}$ foi demonstrada em $\underline{47 \mathrm{~A}}$ e 47C. Predomínio de lamelas longitudinais foi verificado na região posterior do $\mathrm{AF}$, bem como a disposição ligeiramente oblíqua no plano sagital como descrito pela microscopia de luz. Asterisco duplo marca a região do NP, caracterizado pela cavidade formada pelo processo de desidratação. * - placa vertebral; ${ }^{* *}$ - região central. 
Os espécimes cervicais do GI caracterizaram-se por uma estrutura de lamelas bem mais rígida e sem os espaços característicos de GJ (Figura 48). A região posterior do anel apresenta predominantemente fibras longitudinais como já verificado por microscopia óptica, bem como a orientação ligeiramente oblíqua no plano sagital das fibras neste setor (Figura 48B). A região do NP ainda foi visualizada por MEV; esta encontra-se particularmente evidenciada na Figura 48A.
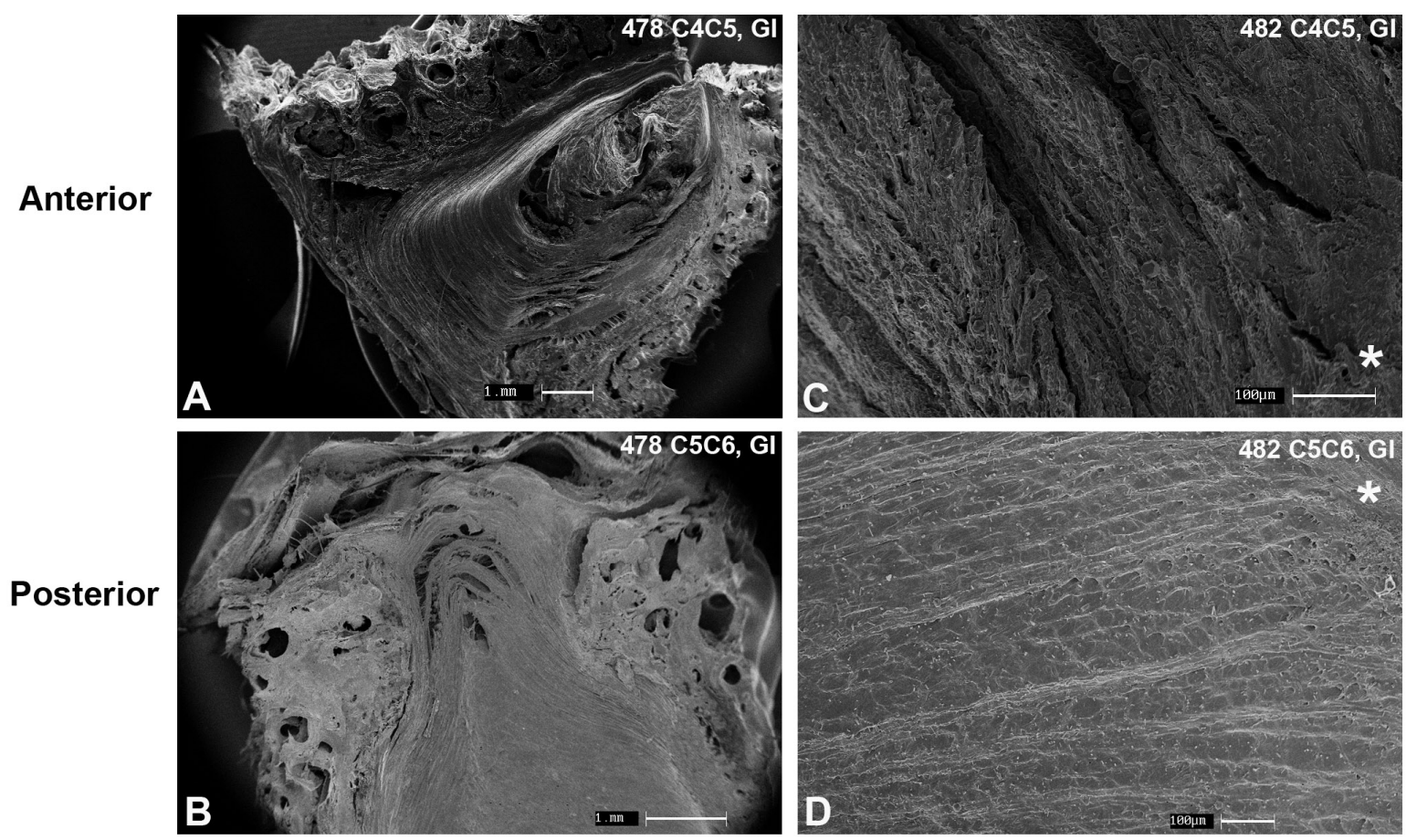

Figura 48 - Discos cervicais, GI, microscopia eletrônica de varredura. Cortes sagitais, setores anterior e posterior. Organização de lamelas nas regiões anterior e posterior do AF é bem mais densa que em GJ; comparar com Figura 47. Predomínio de fibras longitudinais na região

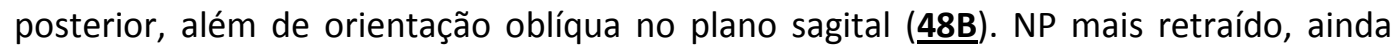
distinto do AF, é visto em $\underline{\mathbf{4 8 A}}$. * - placa vertebral. 
Quanto aos espécimes lombares, a SEM demonstrou claramente o padrão de fibras alternantes nos setores anterior e posterior do AF; ficou evidente o predomínio de fibras longitudinais na região posterior (Figura 49). Além disso, demonstra ainda o padrão de fibras frouxas e sem disposição organizada no núcleo, bem como a falta de uma inserção do mesmo na placa vertebral, ao contrário do que ocorre no AF.

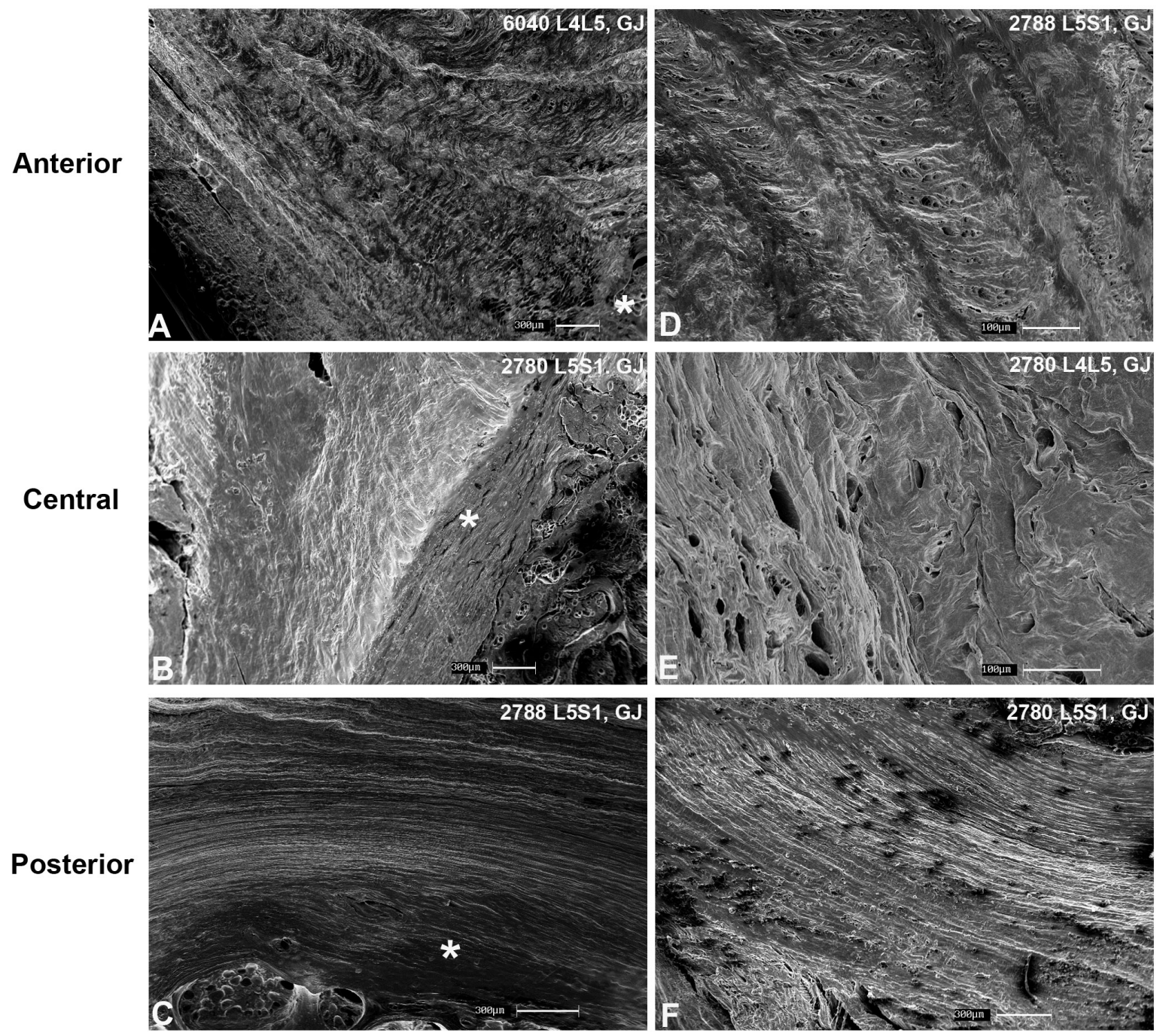

Figura 49 - Discos lombares, GJ, microscopia eletrônica de varredura. Cortes sagitais, setores anterior e posterior do AF e central correspondendo ao NP. Padrão de lamelas alternantes foi visualizado no $\mathrm{AF}$ anterior $(\underline{\mathbf{A}, \mathbf{D}})$ enquanto que o predomínio de lamelas longitudinais é demonstrado no setor posterior $(\underline{\mathbf{C}, \mathbf{F}})$. Percebeu-se ainda como o núcleo não se insere na placa vertebral, além do padrão de fibras frouxas que o mesmo exibe (B, E). * - placa vertebral. 
Nos espécimes lombares de $\underline{\mathbf{G l}}$, está bem demonstrado o adensamento de ambos os setores do AF já visualizado através de microscopia de luz (Figura 50). As lamelas tornaram-se menos distintas umas das outras e o NP apresentou sua matriz também compacta, embora mantendo a distinção do AF. Na Figura 50C ficou bem demonstrado que, apesar de adensado, o AF ainda manteve um plano de clivagem não só com o NP como também com o LLP. Uma fissura transversal ainda foi fortuitamente demonstrada nesta figura.
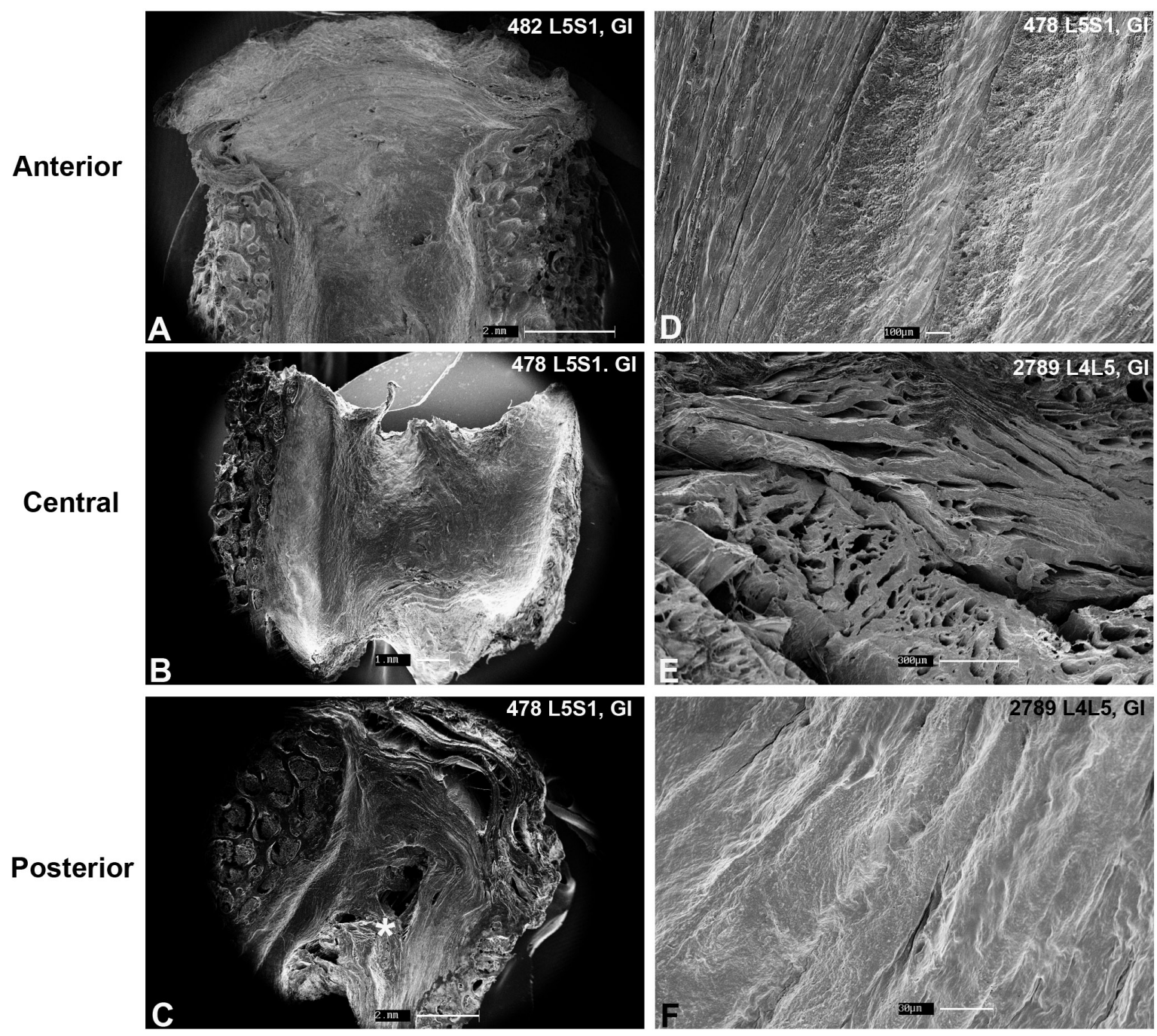

Figura 50 - Discos lombares, GI, microscopia eletrônica de varredura. Cortes sagitais, setores anterior e posterior do AF e central correspondendo ao NP. Tanto o AF anterior quanto o posterior apresentam lamelas bem mais compactas que em $\underline{\mathbf{G J}}$ (50D, F). A matriz de todos os setores está adensada, sem, no entanto, levar a uma perda de distinção entre os mesmos (50C). ${ }^{*}$ - fissura transversal. 


\subsection{Imuno-histoquímica}

A realização do perfil colágeno dos discos estudados foi realizada com sucesso através de análise imuno-histoquímica. Exemplos de marcação dos diferentes tipos de colágeno estão dispostos na Figura 51. Qualitativamente, algum tipo de marcação sempre foi detectada com exceção do colágeno $X$. Os diferentes tipos, entretanto, apresentavam padrões distintos: alguns foram visualizados em paralelo com as fibras que compunham os diferentes setores do disco intervertebral, como proteínas estruturais, como no caso dos colágenos I, II, IV e IX (Figura 51). Outros tipos foram marcados apenas de maneira intra- ou pericelular nos condrócitos do disco, como os colágenos III e VI. O colágeno V apresentou expressão muito mais significativa na placa vertebral, embora alguma expressão filiforme ainda fosse evidente no interior dos discos (Figura 51E).

A distribuição dos diferentes colágenos dentro de cada disco está demonstrada nas Figuras $\underline{52}$ e $\underline{53}$. Todos os colágenos estiveram presentes em todos os discos, com a exceção do colágeno $\mathrm{X}$ - este só foi estatisticamente diferente dos controles negativos nos discos lombares, regiões central e posterior de GJ (Figura 53). De uma maneira geral, colágeno II foi o colágeno predominante nos discos intervertebrais, tanto no segmento cervical como no lombar. Na região cervical, colágeno IV também se destacou como o segundo tipo de colágeno mais frequente (Figura 52). Ambos apresentaram reduções significativas em $\mathbf{G l}$, da ordem de 50-70\%. Já no segmento lombar, embora a predominância de colágeno II tenha se repetido, esta não foi da mesma magnitude que no segmento cervical (Figura 53). O AF também apresentou importante expressão de colágeno IV, enquanto o NP caracterizou-se em GJ pelo elevado conteúdo de colágeno IX. Foi ainda em GJ que se detectou a única expressão significativa de colágeno $X$, nos setores central e posterior, que acabou se perdendo em $\underline{\text { Gl}}$. Nos espécimes de $\underline{\text { Gl}}$, verifica-se novamente a diminuição da expressão de colágeno II, exceto pelo AF posterior, que apresenta um padrão muito similar tanto em $\underline{\mathbf{G J}}$ como em Gl. Há ainda importante diminuição na expressão de colágeno III no AF e o NP perde sua característica expressão de colágeno tipo IX (Figura 53). 

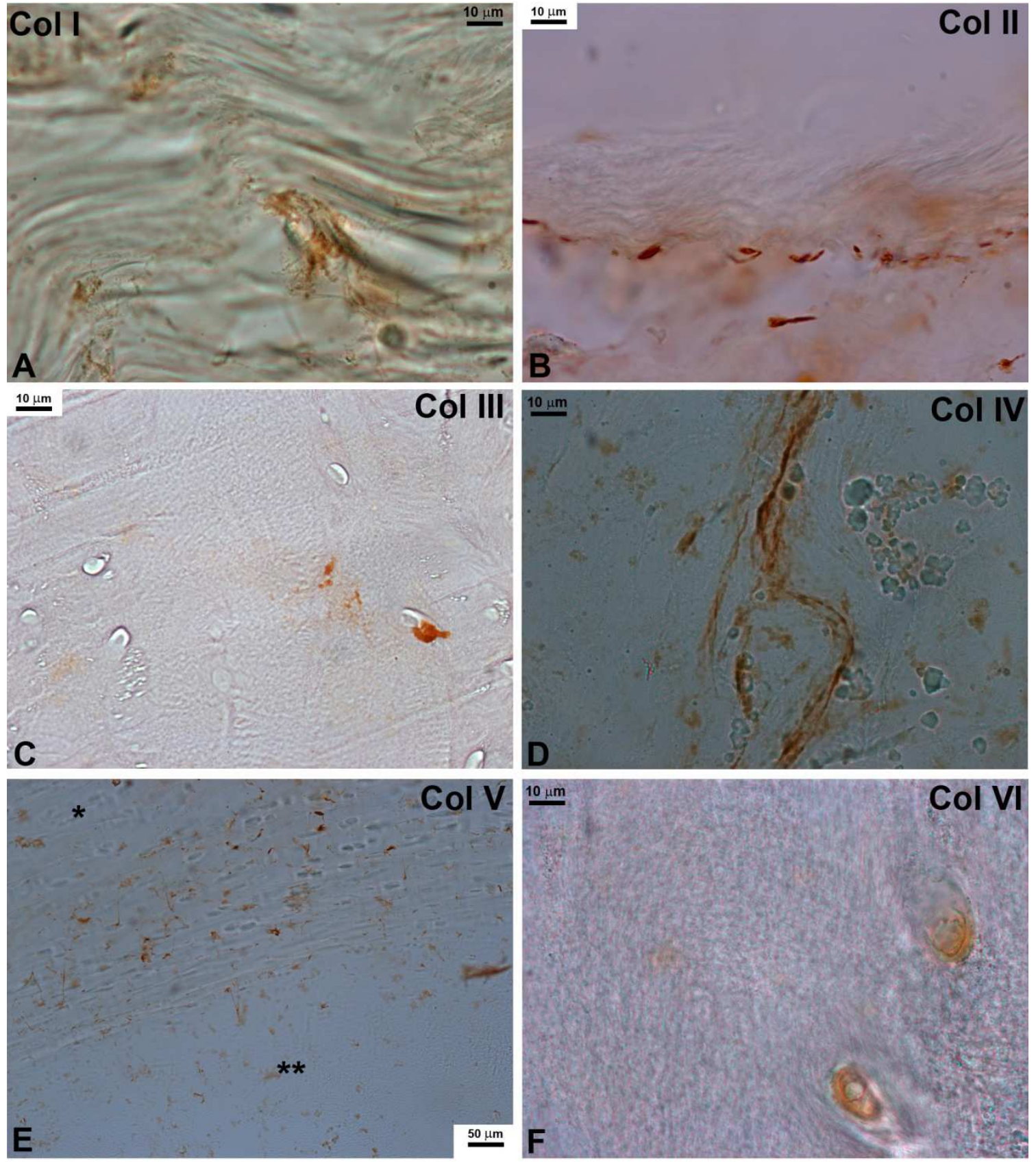

Figura 51 - Continuada - próxima página. 


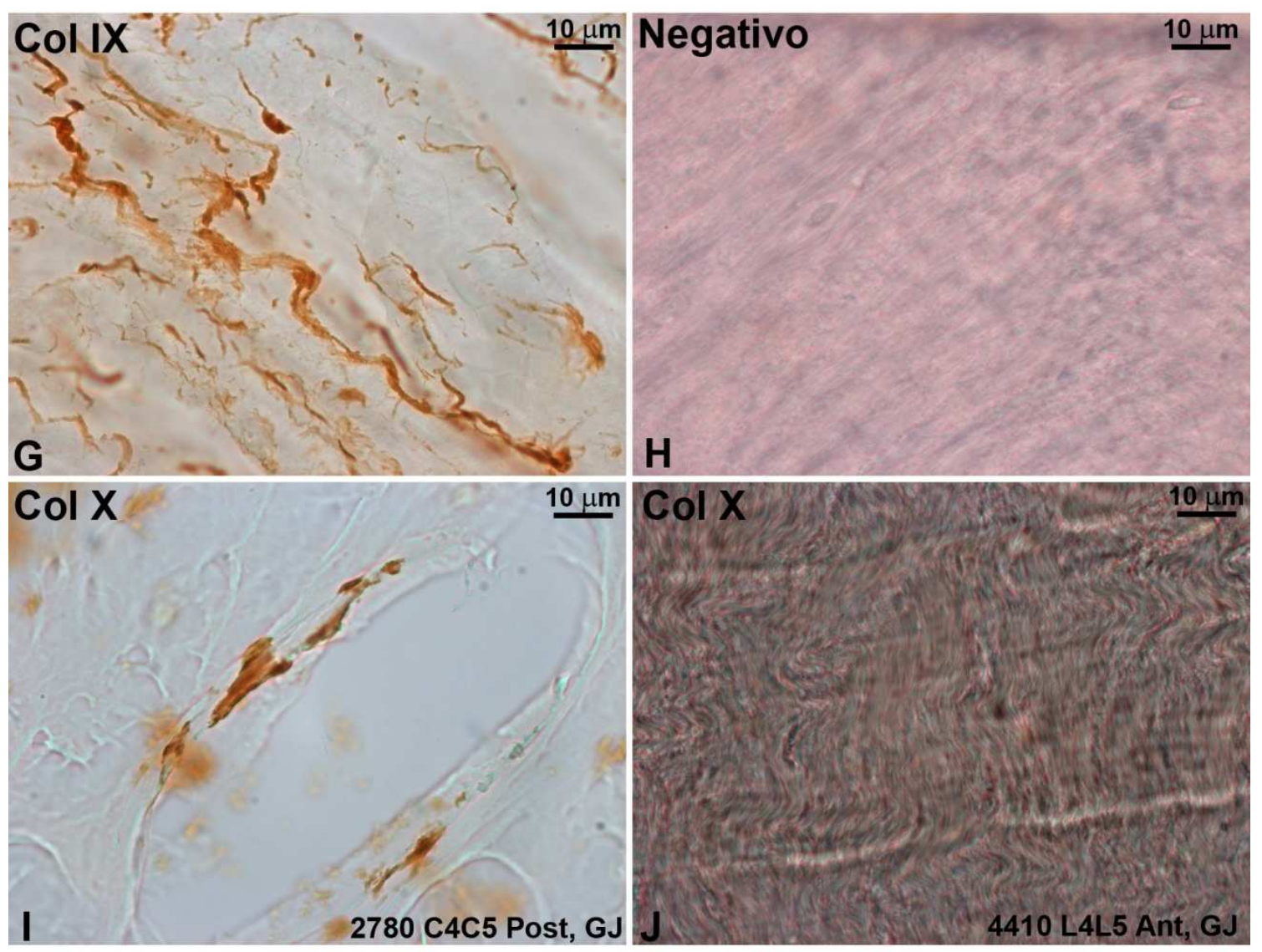

Figura 51 - Imuno-histoquímica, padrões de expressão dos diferentes colágenos. Colágenos tipo I

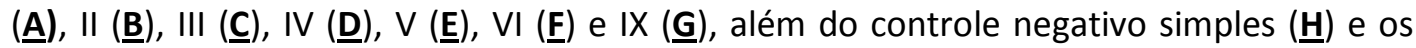
dois diferentes padrões de expressão de colágeno $X$, presente (I) ou ausente (J)). Com a exceção do Colágeno $X$, todos os colágenos apresentaram algum tipo de expressão à avaliação qualitativa, embora o Colágeno $\mathrm{V}$ estivesse praticamente restrito à placa vertebral (E). Com a exceção do colágeno $\mathrm{V}$, os outros colágenos apresentaram um padrão de expressão filiforme, consistente com as fibras que compõe o disco intervertebral ( $\underline{\mathbf{A}, \mathbf{B}, \mathbf{D}}$ e $\underline{\mathbf{G}})$ ou intra- / pericelular ( $\underline{\mathbf{C}}$ e $\underline{\mathbf{F}}) . \quad$ * - placa vertebral; ** - disco.

A variação da expressão dos diferentes tipos de colágeno entre GJ e GI está demonstrada de outra maneira na Figura 54. Nesta figura estão demonstradas as variações por setor, com os respectivos valores de significância estatística. Novamente, destacam-se as variações da expressão do colágeno II, particularmente no segmento cervical, bem como as de colágeno III e IV no AF lombar e a diminuição na expressão de colágeno IX. Ressalta-se ainda que as escalas no eixo das ordenadas não são iguais; assim, as variações da expressão de colágeno II, IV e IX são muito mais significativas que colágenos I e X, por exemplo (Figura 54).

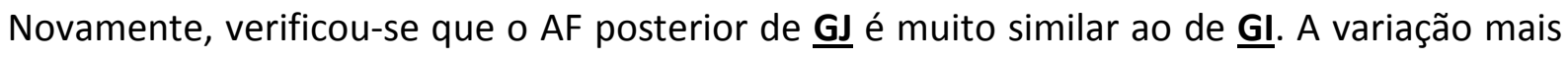


homogênea entre GJ e GI ocorreu com colágeno VI, expresso de maneira similar e que diminui ao longo de todo o disco em $\underline{\text { Gl}}$, exceto pelo AF posterior.

A

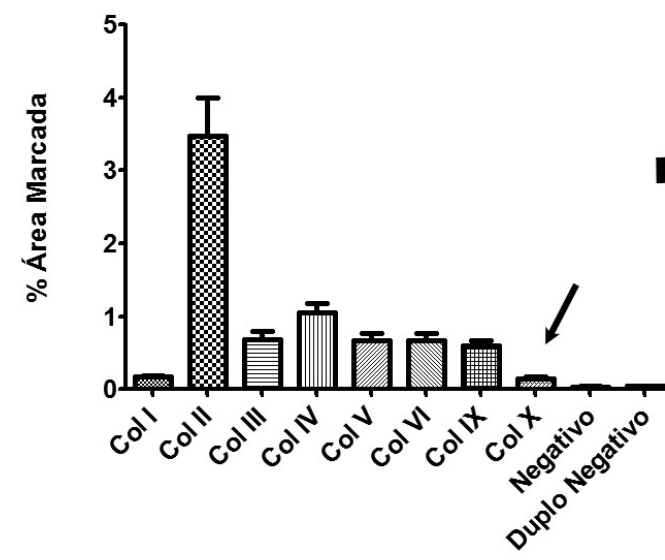

B

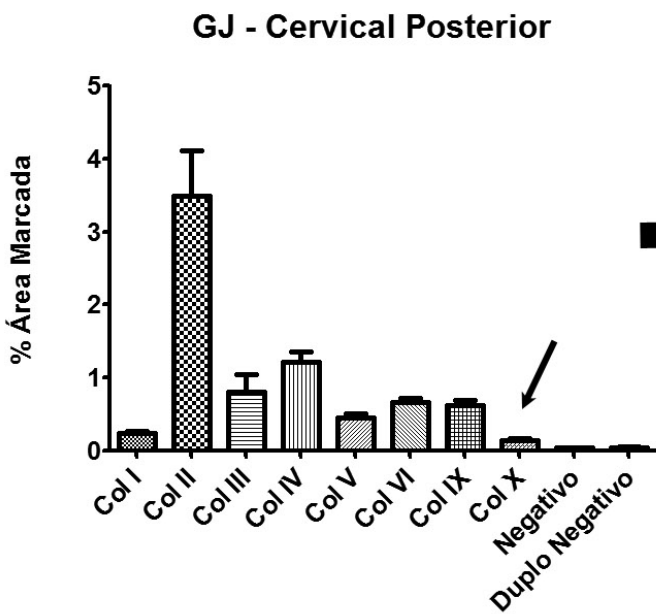

GI - Cervical Anterior

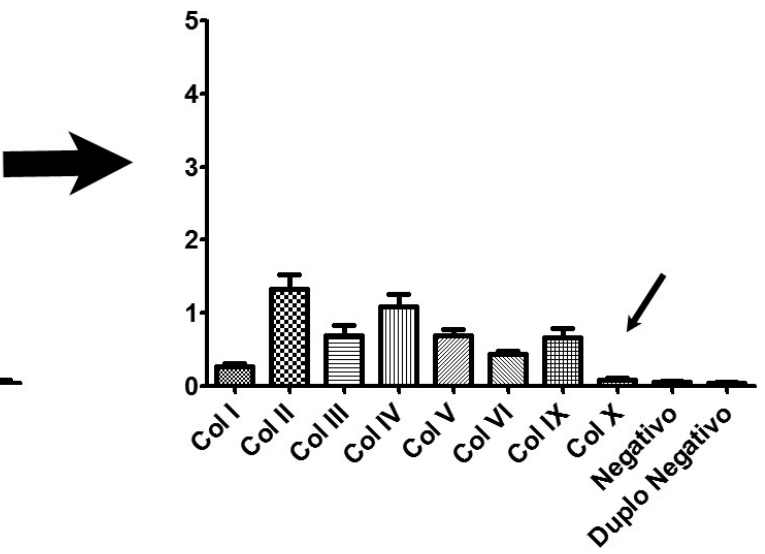

GI - Cervical Posterior

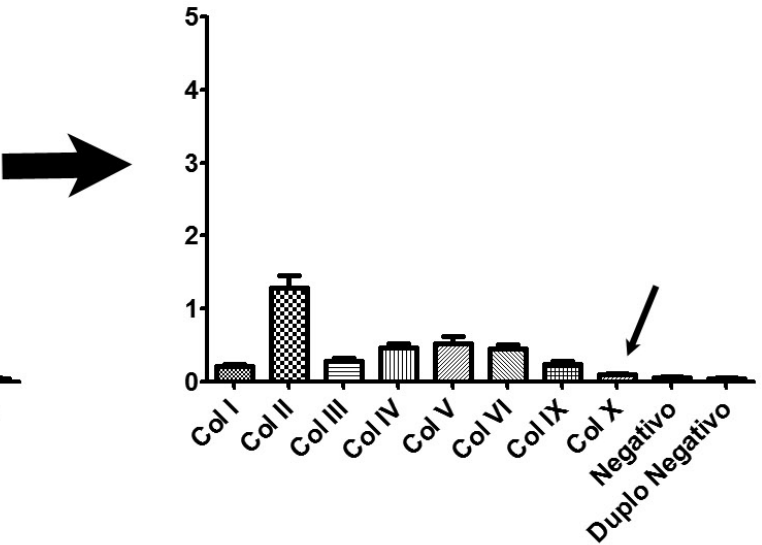

Figura 52 - Imuno-histoquímica, quantificação da marcação dos diferentes tipos de colágeno nos espécimes cervicais. A expressão de todos os colágenos foi estatisticamente significante, à exceção do colágeno $X$; estes encontram-se assinalados no gráfico pelas setas. Os discos cervicais caracterizam-se pela expressão significativa de colágeno II, seguido por um importante componente de colágeno IV. A quantidade de coilágeno II, entretanto, cai mais de $50 \%$ nos espécimes de GI. Colágeno IV também encontra-se reduzido na região posterior dos discos cervicais de $\underline{\mathbf{G l}}$. 
A

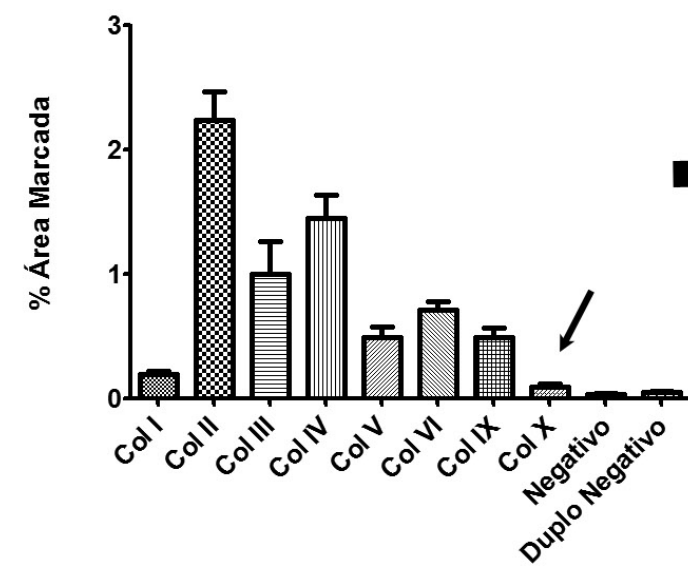

B

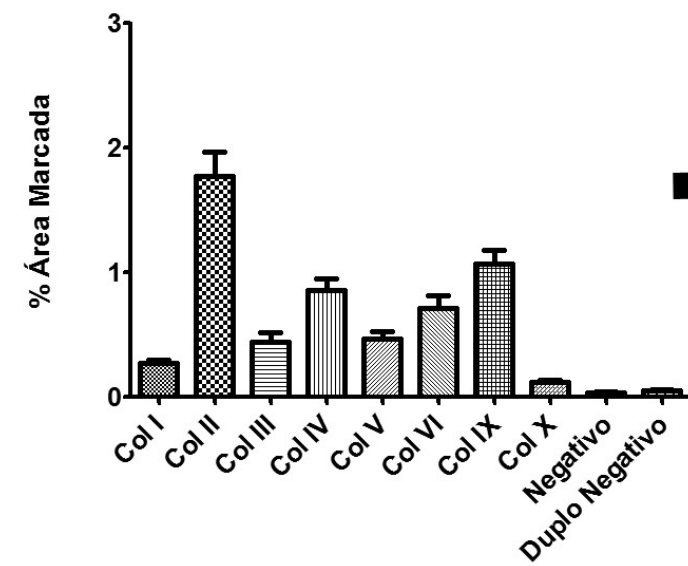

C

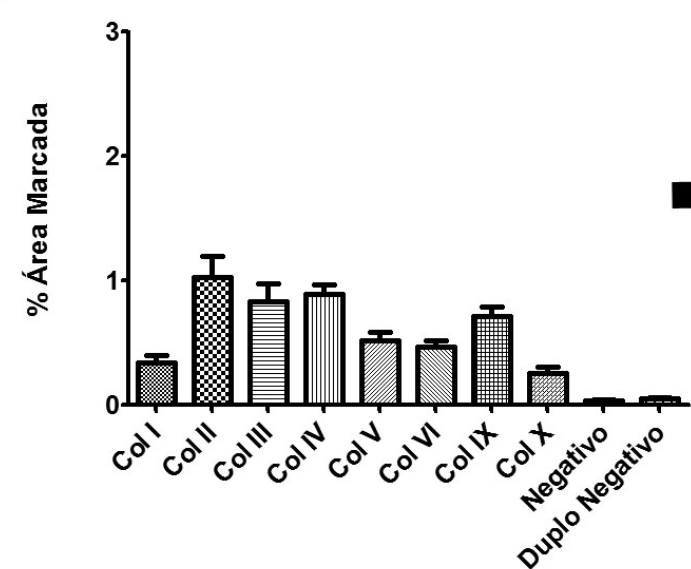

GI - Lombar Anterior

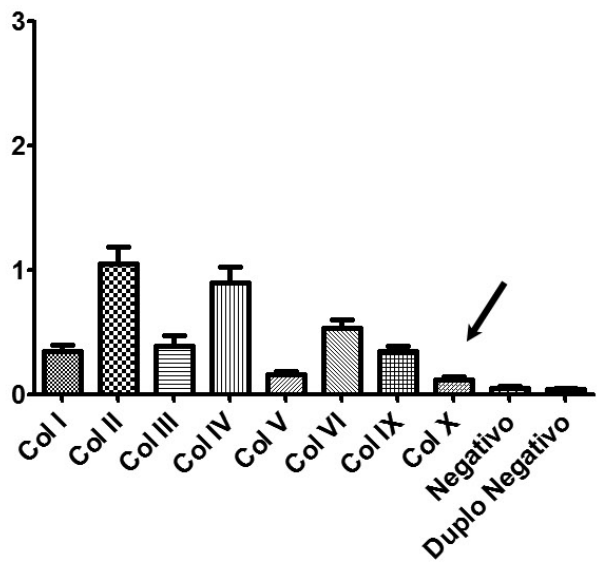

GI - Lombar Central

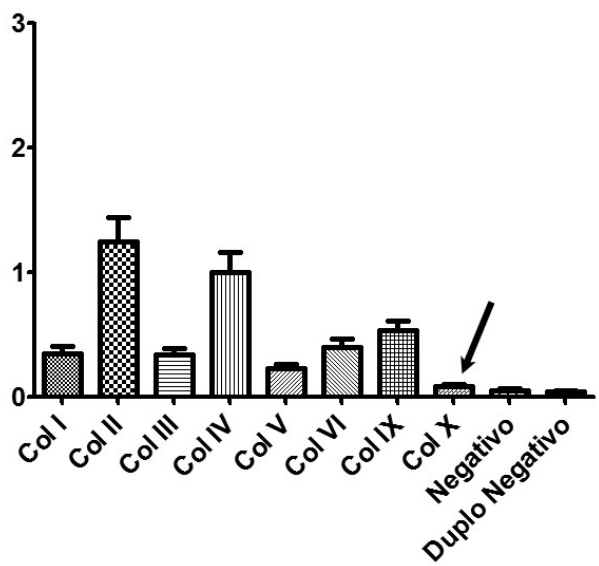

GI - Lombar Posterior

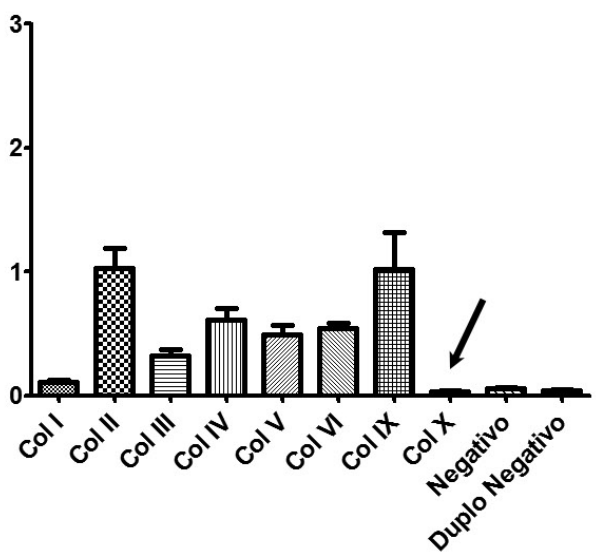

Figura 53 - Imuno-histoquímica, quantificação da marcação dos diferentes tipos de colágeno nos espécimes lombares. A expressão de todos os colágenos foi signiicativamente distinta dos controles negativos, exceto pelo colágeno $X$; este só apresentou expressão significativa nas regiões central e posterior de $\underline{G}$. Assim como na região cervical, colágeno Il é o mais comum, embora em magnitude menor. O padrão colágeno do disco posterior é semelhante em $\underline{\mathbf{G J}}$ e $\underline{\mathbf{G I}}$. Setas assinalam os valores não-significativos de colágeno X. 
A

Colágeno I

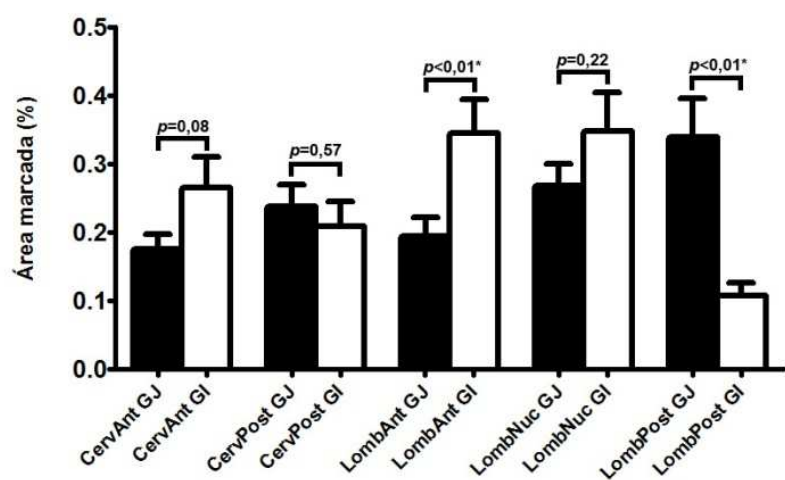

B

Colágeno II

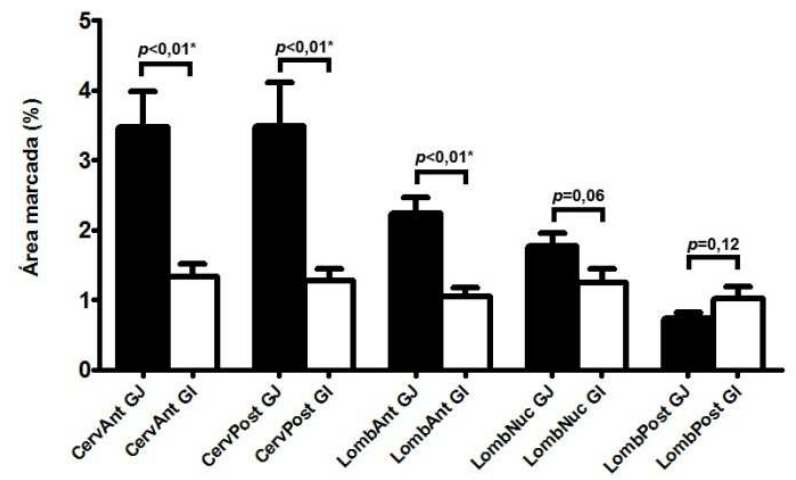

C

Colágeno III

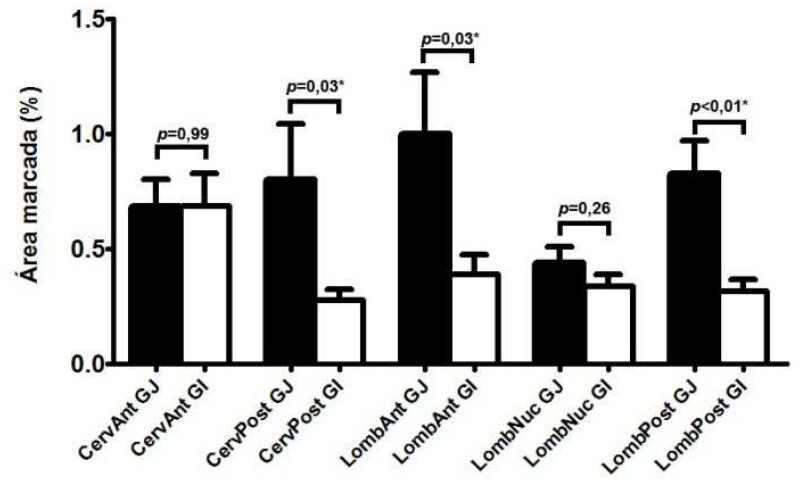

D

Colágeno IV

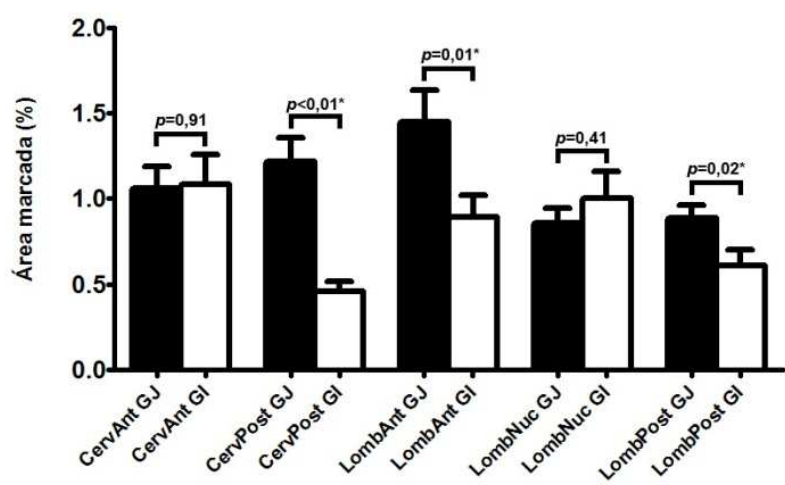

Figura 54 - Continuada na próxima página. 
$\mathbf{E}$ Colágeno V

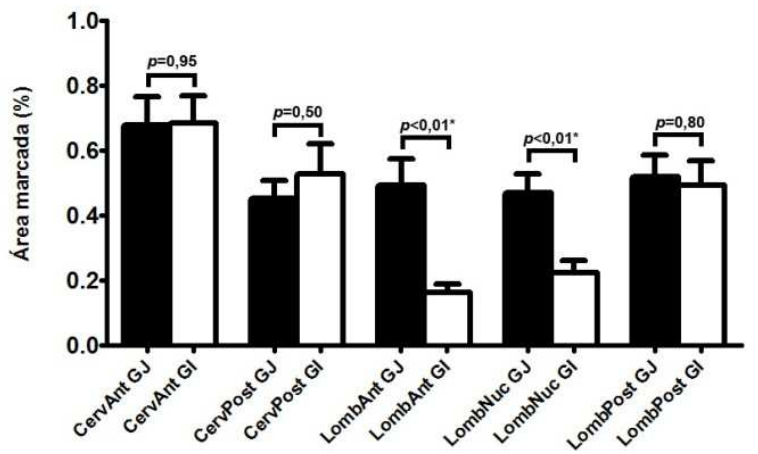

$\mathbf{F}$

Colágeno VI

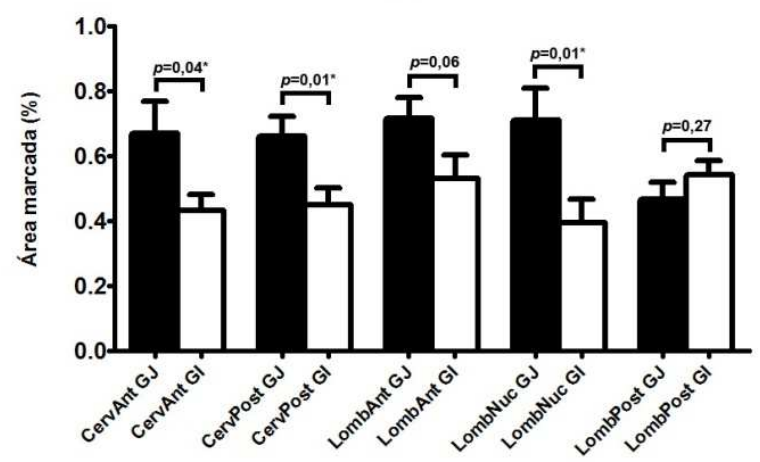

G

Colágeno IX

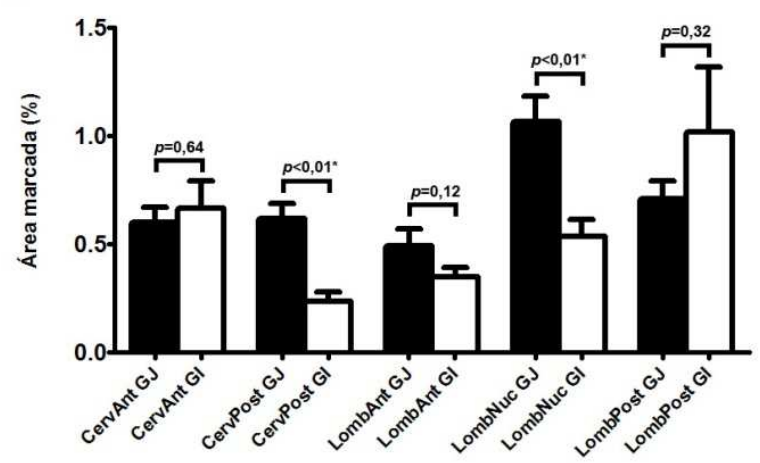

H

Colágeno $\mathrm{X}$

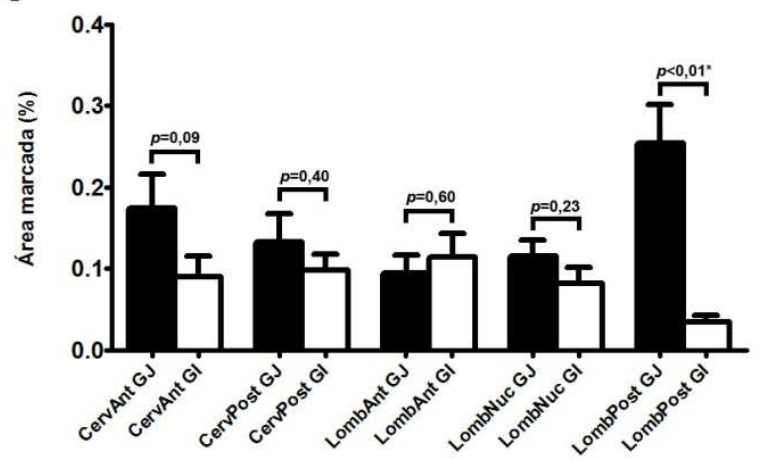

Figura 54 - Quantificação da marcação imuno-histoquímica por tipo de colágeno e localização, bem como os resultados da análise estatística. Observe-se que os eixos de ordenadas não

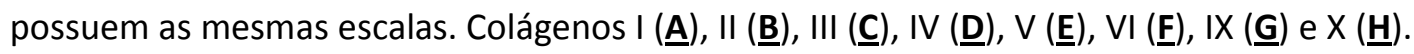


5 Discussão 
Alcançou-se, através do estudo minucioso de uma amostra de discos intervertebrais humanos extraídos de indivíduos assintomáticos, uma descrição bastante extensa das alterações morfológicas que caracterizam o envelhecimento normal do disco intervertebral em adultos jovens e idosos assintomaticos. Apesar de alguns relatos morfológicos existirem na literatura para o segmento lombar, não há estudos similares para os discos do segmento cervical, muito menos para ambos simultaneamente ou utilizando uma gama tão diversa de métodos experimentais como aqui demonstrado ${ }^{1,50,51,53,56,189}$. Uma pesquisa no banco de dados Pubmed em Julho/2011 com os descritores "cervical", "disc", "morphology" e "collagen" resulta em apenas 26 resultados, dos quais 7 envolvem estudos com espécimes humanos e apenas 4 envolvem análise morfológica; todos estes estão citados na presente tese $e^{59,189,209,239}$. Mesmo considerando os principais estudos disponíveis para cada segmento, destaca-se o elevado número de cadáveres e a homogeneidade etária da amostra emrpegada aqui. Os 88 discos dos trabalhos de Coventry et al. distribuiram-se entre 0 e 80 anos de idade ${ }^{1,50,51}$. Nerlich et al. utilizaram no principal estudo morfológico relacionado ao padrão colágeno do disco intervertebral discos oriundos de 47 cadáveres distribuídos entre 0 e 86 anos de idade ${ }^{56}$. Possuem as mesmas características os estudos de Boos et al. (54 cadáveres, 0-88 anos de idade), Vernon-Roberts et al. (40 cadáveres, 17-79 anos de idade) e Gruber e Hanley (39 cadáveres, $30-80$ anos de idade), por exemplo $53,228,240$. Por serem ainda mais raros, estudos dos discos do segmento cervical padecem de maneira ainda mais grave do mesmo problema: Mercer e Bogduk., por exemplo, estudaram apenas 12 cadáveres com idades entre 39 e 82 anos $^{189}$. A grande maioria dos estudos, entretanto, ainda utiliza espécimes cirúrgicos em virtude da dificuldade de se obter este material, em particular aqueles utilizando técnicas imuno-histoquímicas ou de biologia molecular para identificar mecanismos fisiopatológicos de degeneração, como Lee et al. e Roberts et al. Não é raro encontrar-se até mesmo uma mistura indefinida de espécimes cirúrgicos e cadavéricos, como em Purmessur et al. ou LeMaitre et al. ${ }^{102,109,111,123}$. O material aqui empregado é uma das melhores alternativas para estudo da degeneração discal; a potencial fraqueza do método empregado de seleção da amostra é a possibilidade das informações fornecidas pelos familiares serem incorretas e o indivíduo eventualmente ter padecido de cervical ou lombalgia. A única maneira de evitar este possível viés seria cadastrar de maneira prospectiva um elevado número de indivíduos, certificar-se que são de fato assintomáticos 
através de entrevista e fazer com que aceitem serem estudados após morrer; caso apresentem sintomas, seriam excluídos do estudo. Tal estratégia possui dificuldades metodológicas evidentes que a tornam inviável; o estudo de cadáveres após entrevista com familiares torna-se então a melhor alternativa.

A incorporação de uma avaliação por RM permitiu uma aproximação dos dados morfológicos à avaliação realizada pelo clínico durante o processo de investigação da doença degenerativa discal. Trata-se do maior estudo correlacionando RM e análise histológica dos discos íntegros do segmento cervical; na única publicação encontrada na literatura, Christe et al. estudaram 9 cadáveres, dos quais 6 haviam realizado RM. A RM mostrou-se eficaz em demonstrar todas as fissuras e alterações que eram visíveis na avaliação macroscópica; mesmo fissuras diminutas no segmento cervical foram claramente visualizadas. Além disso, não houve discrepância entre a distinção AF-NP conforme vista através de RM ou pela macroscopia. Fissuras microscópicas, como a demonstrada na Figura 34E, com seus pequenos vasos no interior não foram visualizadas nas séries de RM aqui realizadas. Outras alterações próprias da degeneração discal, como proliferação condrocitária e hialinização da matriz extracelular do disco, não foram demonstradas pela RM. A distinção AF-NP, por exemplo, foi sempre possível através de análise histológica (no segmento lombar) e MEV (cervical e lombar). Tal distinção, principalmente em nível cervical, é discreta. A RM irá perceber esta distinção quando o conteúdo e forma de apresentação das moléculas de água em seu interior forem distintas de acordo com a região. No disco, entretanto, sabe-se que a maioria da água em seu interior está ligado a moléculas da classe das proteoglicanas. A quantidade destas moléculas, embora inicialmente maior no NP, correlacionando-se com sua função de absorção de cargas axiais, tende a igualar-se ao longo do disco durante o processo de envelhecimento: pode ser este o motivo da perda da distinção AF-NP à RM. Alterações de parâmetros de RM ou utilização de um scanner mais potente poderiam potencialmente detectar tais alterações; por outro lado, tais parâmetros deixariam de ser representativos do ambiente de decisão clínico que se encontra na prática neurocirúrgica diária. Christe et al. já apontaram em 2005 que estes parâmetros eram insuficientes para detectar todas as alterações morfológicas visualizadas por histologia: em seu estudo, apenas $40 \%$ das fissuras foram detectadas por RM, com sensibilidade ainda menor para outras 
alterações morfológicas ${ }^{203}$. Assim como Christe et al., neste estudo não se notaram outras alterações que não prolapso, condro/osteófitos ou fissuras pela RM; todas as outras alterações histológicas permaneceram ocultas. A discrepância entre nossos dados e os de Christe et al. com relação à sensibilidade para fissuras é facilmente explicada por diferentes padrões de confirmação: neste estudo consideraram-se apenas aquelas fissuras detectáveis em análise macroscópica enquanto que Christe et al. consideraram também aquelas aparentes à análise histológica.

A avaliação macroscópica confirmou muitos dados presentes em literatura, mas também serviu como método de avaliação qualitativo para ulterior comparação e padronização com os resultados dos demais métodos. Todas as categorias de Thompson estiveram representadas e a coleção de imagens obtida torna-se uma excelente representação gráfica desta classificação. Comprovou-se na população estudada que alterações degenerativas macroscópicas são a regra e não a exceção. Mesmo em GJ, nenhum cadáver apresentou-se com todos os discos Thompson 1, mostrando já algum acúmulo de alterações degenerativas aos 35 anos de idade como apontado por Slivola et al., Okada et al. e Matsumoto et al. ${ }^{187,188,241}$. Os discos cervicais foram relativamente mais degenerados que os lombares; ao menos em parte, isto poderia ser explicado pelo fato da classificação de Thompson ter sido desenvolvida para o segmento lombar e certos critérios, como distinção AF-NP, serem mais difíceis de analisar no segmento cervical. Discos grau 1 foram raros no segmento cervical mesmo em GJ (2/30), mostrando que alterações degenerativas foram suficientemente acumuladas na maioria dos discos a ponto de induzir alterações macroscópicas. Por outro lado, apenas um disco Thompson 5 foi encontrado no segmento cervical em $\underline{\mathbf{G J}}$, e nenhum no segmento lombar. Apesar de degeneração avançada em indivíduos jovens também não ter sido rara (25\% dos discos estudados receberam classificação Thompson 4 ou 5), colapso estrutural completo é raro e estes discos degenerados de $\underline{\mathbf{G}}$ recebem classificação elevada por fissuras e/ou osteófitos adjacentes.

Confirmando os dados de literatura nesta população, os anos que separam $\underline{\text { GJ }}$ de $\underline{\text { GI }}$ induziram importantes alterações macroscópicas: quase a metade (28/60) dos discos de $\mathbf{G I}$ 
recebeu classificação Thompson 5. Isto mostra que graus avançados de degeneração são a regra nesta faixa etária. Entretanto, estes espécimes de $\mathbf{G l}$ a receberam muitas vezes por colabamento discal, ao contrário daqueles de $\underline{\mathbf{G J}}$. Tal distinção na literatura entre discos Thompson 5 de individuos jovens (fissuras e/ou osteófitos) e idosos (colapso) nunca foi reportada, embora já houvesse na literatura a percepção que a escala de Thompson seria insuficiente para captar todas as nunces morfológicas da degeneração discal ${ }^{53}$. Alguns dos resultados desta avaliação podem ter aplicação clínica direta no diagnóstico e investigação etiológica da doença degenerativa discal: talvez a presença de graus avançados de degeneração não seja um problema para os pacientes, mas sim a heterogeneidade morfológica entre diferentes discos. Os dados do presente estudo mostram que embora alguma variação entre segmentos seja aceitável em jovens e até comum em idosos (2 graus de Thompson), esta mesma variação dentro de um segmento ou variações mais extremas entre segmentos (3 graus de Thompson) é anormal e deve ser valorizada pelo clínico. Okada et al. demonstraram através de RM no único estudo comparativo de morfologia cervical e lombar na literatura que a co-existência de alterações morfológicas é comum, chegando a acometer $88 \%$ de indivíduos assintomáticos e $98 \%$ de pacientes recebendo tratamento para lombalgia. Em linha com nossos resultados, entretanto, demonstraram que tais achados são em geral homogêneos e grandes variações não devem ser esperadas seja intra- ou intersegmentos ${ }^{242}$.

A utilização de quatro diferentes técnicas histológicas resultou em um perfil morfológico abrangente dos diferentes setores discais tanto no segmento cervical como lombar. Em primeiro lugar, torna-se evidente que estes setores discais aqui estudados (AF anterior, NP e AF posterior) são absolutamente distintos sob qualquer uma das técnicas utilizadas. Apesar de este dado estar presente na literatura desde as descrições de Luschka há mais de 150 anos, ainda são abundantes os trabalhos na literatura que não citam ou não distinguem o setor discal analisado ${ }^{26}$. Shamji et al. publicaram recentemente um detalhado estudo sobre a expressão de citocinas proinflamatórias em discos de indivíduos sintomáticos; mesmo a distinção grosseira entre AF e NP não foi feita e compromete a análise de seus resultados ${ }^{243}$. A distinção entre regiões anterior e posterior do AF é ainda mais rara de ser feita e diversos dos estudos citados na revisão fisiopatológica da primeira parte desta tese não a 
fazem $^{96,101,107,111,244}$. As descrições do disco intervertebral encontradas na obra de Testut em 1905 já incluem a assimetria do AF dos discos do segmento lombar e apontam certas características únicas dos discos do segmento torácico em comparação com os discos lombares ${ }^{27}$. Mercer e Bogduk realizaram em 1999 a mais completa análise até hoje encontrada na literatura acerca da morfologia única do AF e ligamentos longitudinais no segmento cervical da coluna vertebral de humanos ${ }^{189}$. Embora estes autores tenham apresentado a ausência de distinção entre LLA e AF anterior como sendo característica do disco cervical, nossos dados demonstram que o mesmo também ocorre no segmento lombar sob avaliação macroscópica ou HE: as Figuras 13 e $\underline{29}$ demonstram como o LLA é indistinguível na coloração HE. As Figuras $\mathbf{2 1}$ e $\underline{\mathbf{3 6}}$ mostram que o mesmo ocorre quando se examina o disco corado por Picro-Sirius sob luz normal; a polarização, por outro lado, prontamente revela o limite entre LLA e AF anterior. Isto pode ocorrer devido a um maior componente de colágeno tipo I no LLA em relação ao AF como já citado por Beard et al. em um dos primeiros estudos de imunolocalização de colágeno no disco intervertebral ${ }^{69,189}$. Segundo Mercer e Bogduk, a única diferença entre as fibras mais profundas do LLA e as superficiais do AF seria o modo de inserção das mesmas no corpo vertebral: mesmo as fibras mais profundas do LLA já inserir-se-iam nos corpos vertebrais acima e abaixo ${ }^{189}$. Propõe-se aqui que este método de distinção é inadequado, uma vez que tal trajeto seria mais compatível com o segmento superficial do disco, e sugere-se a utilização da fronteira entre os diferentes tipos de colágeno, com a ressalva de não haver distinção macroscópica e possivelmente funcional.

Outra característica apontada por Mercer e Bogduk como típica dos discos do segmento cervical é a ocorrência de camadas longitudinais e oblíquas na região anterior dos discos cervicais $^{189}$. Pooni et al. apontaram inicialmente esta característica em $1986^{196}$. Estas camadas foram descritas como estando dispostas de maneira entremeada e que, portanto, o uso do termo "lamelas" para descrever as camadas do AF cervical seria inadequado ${ }^{189}$. Demonstramos aqui que tal disposição é encontrada não apenas em uma população idosa mas também nos adultos jovens; Mercer e Bogduk haviam levantado a possibilidade desta disposição na verdade ser uma alteração típica do envelhecimento uma vez que a população por eles estudada era idosa ${ }^{189}$. Embora tenha se confirmado aqui esta disposição nos discos 
do segmento cervical, verificou-se que não é exclusiva deste segmento, mas está presente nos discos do segmento lombar (ㅌiguras 29 e $\underline{\text { 35) }}$. Esta característica pode não ter sido descrita anteriormente por falta de um estudo histológico criterioso e com secções orientadas de maneira diversa. Assim, propõe-se aqui, de maneira um pouco menos radical que Mercer e Bogduk, que o termo "lamelas" possa ser utilizado para descrever principalmente o aspecto macroscópico do anel fibroso, mas que se ressalte que sua ultraestrutura está disposta de maneira entremeada tanto no segmento cervical quanto lombar $^{189}$. Derruba-se também a tese proposta pelos mesmos autores que tal disposição seria uma das características anatômicas que permitiriam a maior amplitude de rotação entre as vértebras cervicais.

Uma característica do estudo de Mercer e Bogduk que se confirmou aqui, entretanto, é a exclusividade de fibras com disposição longitudinal na região posterior do $\mathrm{AF}^{189}$. Na verdade, as Figuras 17 e $\underline{\mathbf{2 3}}$ demonstram um pequeno componente ortogonal em meio aos feixes longitudinais. Ao contrário da região anterior do AF, estes feixes não são praticamente da mesma espessura dos longitudinais, mas muito mais delgados. Propõe-se então que não sejam considerados feixes, mas "pontes" entre os feixes longitudinais. Todavia, na região posterior do AF dos discos do segmento lombar este componente oblíquo é bem mais espesso que no segmento cervical, ainda que a maioria destes feixes seja também longitudinal (Figuras 32, 33 e 39). Nesta análise histologica, percebe-se ainda que de todas as regiões discais estudadas, é no segmento posterior do AF lombar que GJ é mais similar a GI. Esta foi uma percepção não apenas da análise histológica mas também de MEV e imunohistoquímica. Além disso, no AF lombar nunca se perdeu completamente a disposição por feixes, ao contrário do AF cervical.

Muitas das conclusões obtidas acerca do arranjo de fibras conjuntivas no AF devem-se ao emprego da coloração de Picro-Sirius neste estudo. Os feixes de conjuntivo do AF foram muito bem delineados, como nosso grupo de pesquisa já havia demonstrado em outras estruturas com elevado teor de conjuntivo, e mantêm um contraste bastante evidente com a matriz desorganizada do NP, onde os feixes são bem mais delgados e sem orientação 
particular (Figuras 35 a $\underline{39})^{227}$. Apenas Melrose et al. haviam utilizado esta técnica anteriormente no disco intervertebral de ovinos, em busca de pontes trans-lamelares no $\mathrm{AF}^{83}$. Este método mostrou-se de fato ideal para o estudo dos feixes conjuntivos do $\mathrm{AF}$, embora os dados de polarização não tenham se correlacionado perfeitamente com os resultados da imunolocalização.

Empregou-se ainda a coloração de Picro-Sirius na expectativa de se obter uma estimativa do padrão colágeno de maneira mais rápida, barata e abrangente que qualquer método de imunolocalização. Estudos anteriores de nosso laboratório dependeram desta técnica para distinguir colágeno I e III no filamento terminal, canal adutor e côndilo mandibular através da análise de refringência $224,227,245$. Este método seria particularmente atraente para o disco intervertebral pela dificuldade em se analisar o disco inteiro por imuno-histoquímica, apontada por diversos autores na literatura e pela suposta abundância destes tipos de colágeno no disco ${ }^{56,83}$. Além de se tratar de método de uso corrente na literatura, há de se admitir um certo elemento de "bairrismo" por se tratar de técnica aprimorada pelos falecido Professor Gregório Montes, reconhecido pioneiro nesta técnica que chegou a ministrar aulas na Faculdade de Medicina da Universidade de São Paulo em passado recente ${ }^{77,81,225,246,247}$.

A análise isolada dos resultados da refringência mostra incialmente que se obteve sucesso: a Figura 21B , por exemplo, demonstra claramente o predomínio de refringência avermelhada na região anterior do disco, gradualmente adquirindo tonalidade amarelo-esverdeada nas regiões mais profundas do AF refletindo um componente de colágeno I na periferia e um aumento na quantidade de colágeno III no interior. Além disso, a refringência "opaca" ou azulada, segundo Montes, característica do colágeno II e rara de ser demonstrada, foi demonstrada em diversas ocasiões nos discos deste trabalho, como nas Figuras 35B, $\underline{\text { 36B }}$, $\underline{36 \mathrm{D}}, \underline{38 \mathrm{~B}}$ e $\underline{38 \mathrm{D}}^{77}$. Entretanto, é inegável que praticamente todas as figuras de Picro-Sirius mostradas nesta tese possuem um elevado componente de refringência amarela ou vermelha, sugerindo que colágeno I seja o prevalente no disco, como as Figuras 21D, 23B, 23D e 35D. Sabe-se, a partir do resultado de imuno-histoquímica que será comentado adiante, que isto não é verdade e colágeno tipo II é o mais abundante: a área corada no 
estudo de IHC por colágeno II chega a ser quase 10 vezes a do colágeno tipo I. Considerandose a elevada especificidade do método de imunolocalização para cada tipo de colágeno, reconhece-se que a análise de refringência pode não estar sempre correta. Uma hipótese para explicar este fenômeno pode ser extraída do método de geração da refringência. Diferentes tonalidades são geradas por fibrilas de diferentes diâmetros e comprimentos: fibras mais compridas geram refringência vermelha, e são típicas de colágeno tipo I, enquanto que fibras de colágeno tipo III são mais delgadas na análise por microscopia eletrônica de transmissão e geram refringência verde. Assim, Montes já sugeria em 1996 que fibras imaturas e mais delgadas de colágeno I ou seccionadas em determinado plano poderiam gerar refringência esverdeada ${ }^{77}$. A geração de excesso de coloração amarela nunca foi comentada na literatura. Presume-se aqui que a geração de refringência amarela em excesso é por identificação de muitas fibras mais grossas; isto poderia ocorrer nestes espécimes por se tratar de uma estrutura com elevado teor de fibras conjuntivas e extremamente compacta. Considerando-se ainda que à época do desenvolvimento da análise de refringência (década de 1980) não se conhecia a maioria dos tipos de colágeno hoje existentes (embora os fibrilares I, II, III e IX o fossem), recomenda-se cautela no emprego deste método em estruturas compactas como o disco e sugere-se a confirmação com uma pequena amostra submetida a técnicas imunolocalizatórias antes de se aceitar os resultados de Picro-Sirius sem reservas.

Apesar dos resultados controversos de Picro-Sirius, diversos caracteres morfológicos clássicos de degeneração discal foram verificados na amostra deste estudo na coloração por HE. Tomando por base a excelente revisão de Boos et al., presença de condrócitos no interior do disco, por vezes em clusters de mais de 15 células, fissuras no AF e vasos neoformados no seu entorno (Figura 34), proliferação e espessamento da placa vertebral e alteração da matriz extracelular com fibrose foram todos encontrados nos discos do analisados $^{53}$. A modificação da matriz extracelular foi descrita por Boos et al. como fibrose $(\text { scarring })^{53}$, sem maior detalhamento. Este termo passa a idéia de uma proliferação de tecido conjuntivo sem controle para preencher uma falha ou fissura. A partir dos resultados demonstrados nesta tese, pode-se dizer com segurança que trata-se de processo de modificação estrutural muito mais complexo que simples "fibrose". O AF dos discos do 
segmento cervical de $\underline{\text { GI }}$ não mais apresenta o espaço que existia nos discos de $\underline{\text { GJj; }}$ estes feixes passam a ser muito mais compactos, tanto na região anterior quanto posterior. 0 processo de compactação é tão exacerbado nos discos da região cervical que prossegue até o desaparecimento completo dos feixes e substituição por uma matriz sólida repleta de condrócitos, como visualizado na Figura 15. Nos discos da região lombar, entretanto, os feixes nunca desaparecem por completo. Esta modificação da matriz também ocorre no NP, a ponto de não haver uma distinção nítida do limite entre o mesmo e o AF na grande maioria dos espécimes já de $\underline{\mathbf{G J}}$ - a Figura $\mathbf{1 6}$ mostra um exemplo de remanescente nuclear com matriz frouxa, encontrado em apenas dois espécimes. Nos espécimes de $\underline{\text { Gl}}$, o NP já adquiriu aspecto idêntico ao do AF no segmento cervical. Como os feixes do AF dos discos do segmento lombar nunca desaparecem, o NP em geral pode ser definido, embora com matriz muito mais compacta. Tomando-se por base que Boos et al. estudaram espécimes lombares, os resultados aqui expostos em geral confirmam o que estes autores publicaram, com as ressalvas de tal processo ser muito mais complexo que simples "fibrose" e ocorrer de maneira ainda mais exacerbada nos discos da região cervical ${ }^{53}$.

Boos et al. consideraram os aspectos morfológicos da degeneração discal em sua classificação sem englobar o fator etário ${ }^{53}$. Os achados aqui apresentados mostram que, muitas vezes, espécimes de um mesmo grau degenerativo de Thompson apresentavam aspecto histológico semelhante a despeito de pertencerem a $\underline{\mathbf{G J}}$ ou $\mathbf{G l}$, e neste sentido concordam com o postulado por Boos et al. ${ }^{53}$. Entretanto, isto nem sempre foi verdadeiro, particularmente em nível cervical: proliferação condrocitária em grandes grupos de mais de 15 condrócitos, por exemplo, foi demonstrada em espécimes de GJ que até receberam baixa classificação de Thompson (Figura 19). O mesmo ocorreu com adensamento do AF (Figura 20) e modificação do padrão de fibras elásticas, como se verá a seguir. Uma vez que adensamento anular e proliferação condrocitária nem sempre se refletiram na classificação de Thompson, que avaliaria aspectos estruturais mais gerais do disco, possivelmente estas alterações seriam as mais precoces dentre todas elas. Estes grupos de condrócitos foram encontrados em número e tamanhos muito maiores nos discos cervicais. Especificamente o critério de grupos com mais de 15 condrócitos conferia uma pontuação muito severa na classificação de Boos et al $^{53}$. Pela frequência com que aparecem nos discos cervicais, 
inclusive naqueles com Thompson baixo, sugere-se que o valor desta característica não seja tão elevado para "quantificar" a degeneração no segmento cervical.

As técnicas de Verhoeff e Weigert demonstraram um elevado conteúdo de fibras elásticas nos AF dos discos cervicais e lombares: de maneira geral, achados de fibras elásticas não foram discrepantes dentro de um mesmo disco. Estas fibras comportaram-se de maneira bastante distinta nos segmentos cervical e lombar de ambos os grupos. No segmento cervical, a maioria dos espécimes de $\underline{\mathbf{G J}}$ apresentou abundância de fibras elásticas no AF, tanto em Verhoeff como Weigert. Entretanto, não foram poucos os espécimes que, sem motivo aparente e com a mesma classificação de Thompson, muitas vezes baixa, que as apresentavam em quantidade muito menor. Este achado não se correlacionou com a presença de outros caracteres degenerativos e não consistiu em falha do método, como amplamente demonstrado na seção de Resultados pela detecção simultânea das mesmas fibras nos ligamentos longitudinais das mesmas peças. De qualquer maneira, estas fibras elásticas praticamente desapareceram dos espécimes de $\underline{\mathbf{G l}}$ com a exceção de um único exemplar (igura 27). Mesmo neste exemplar as fibras do sistema elástico estavam com seu arranjo completamente alterado, as fibras maduras tendo perdido seu arranjo paralelo com o conjuntivo da região posterior do AF e as elaunínicas mantendo-o.

Os achados de fibras elásticas foram ainda mais abundantes no segmento lombar dos espécimes de $\underline{G}$, sem a discrepância demonstrada no segmento cervical - todos os espécimes de GJ com baixo grau de Thompson demonstraram profusão de fibras elásticas no AF. Neste setor, entretanto, os espécimes de GJ com Thompson elevado apresentaram uma menor quantidade de elásticas, particularmente sob a coloração de Verhoeff. Isto sugere que as primeiras fibras a desaparecerem durante o processo degenerativo no segmento sejam as fibras elásticas maduras, enquanto as fibras elaunínicas permanecem por um período indeterminado. Os espécimes de $\mathbf{G I}$ apresentaram quantidade menor de fibras elásticas de maneira homogênea em ambas as técnicas, quando comparado com espécimes com mesmo grau de Thompson de $\underline{\mathbf{G J}}$, ainda que ainda existam em quantidade significativa no AF de espécimes de $\underline{\mathbf{G l}}$ com Thompson baixo. Ao contrário de $\underline{\mathbf{G J}}$, os espécimes 
degenerados de GI apresentaram redução no conteúdo de elásticas em ambas as técnicas: uma vez degenerados, discos de GI continham quantidade muito menor destas fibras.

Poucos autores estudaram o sistema de fibras elásticas em discos intervertebrais de qualquer espécie, ainda mais humanos. Buckwalter et al. publicaram o primeiro estudo em 1976 utilizando microscopia eletrônica de transmissão, relatando pela primeira vez a ocorrência de tais fibras em discos humanos ${ }^{208}$. Em virtude do método empregado, entretanto, não puderam concluir a respeito de seu arranjo; tal análise seria feita pela primeira vez por Johnson et al. em 1982, surpreendentemente em discos cervicais, detectando-as em paralelo nos feixes do AF bem como inserindo-se nos corpos vertebrais à maneira de fibras de Sharpey ${ }^{209}$. Alguns dados de modelos de cauda de animais sugeriram que haveria fibras elásticas em profusão no NP, com arranjo radial: nossos dados demonstraram poucas fibras no NP, demonstrando como estes dados de modelos animais sem carga podem não ser aplicados a discos humanos ${ }^{248}$. Os mesmos autores, comparando estes dados com os de espécimes cirúrgicos jovens, apontaram para uma maior quantidade de fibras no AF e arranjo idêntico ao aqui descrito, assim como Smith e Fazzalari ${ }^{248}$. Um resultado discrepante de todo o restante da literatura foi publicado por Cloyd e Elliott em 2007: ao dosar a quantidade de elastina em discos discos degenerados e não-degenerados, concluíram que o conteúdo de elastina aumentava com a degeneração, tendo normalizados os resultados para peso seco do disco para evitar viés pelo conteúdo de proteoglicanas e água $^{249}$. Além disso, sustentam que não houve variação regional ( $A F$ versus NP). Os resultados aqui demonstrados não suportam estes argumentos, embora Cloyd e Elliott tenham utilizado um método quantitativo que certamente é mais acurado para dosar elastina. Por outro lado, ressalte-se que enquanto Cloyd e Elliott dosaram elastina, as técnicas de Verhoeff e Weigert demonstram as fibras elásticas e elaunínicas, que são compostas por elastina mas também por outras proteínas, e portanto os termos não são sinônimos. Fibras elásticas desapareceriam primeiro em espécimes degenerados de $\underline{\text { GJ }}$, mas elastina ainda participa da composição de fibras elaunínicas presentes nos mesmos espécimes degenerados. Outros exemplos de como a presença de elastina pode ser distinta da presença de fibras elásticas estão nas Figuras $\mathbf{4 3}$ e $\underline{\mathbf{4 4}}$ : fibras elásticas não chegam a ser demonstradas no NP de discos lombares, embora as figuras possuam coloração suficiente 
para sugerir a presença de elastina. Neste sentido, a demonstração histológica faria mais sentido que a simples dosagem de elastina pois forneceria uma correlação funcional. Além disso, Cloyd e Elliott não padronizaram seus resultados por idade, utilizando discos de cadáveres com idades de 19 a 80 anos e já reconheceram este como um potencial viés de seu estudo, além de utilizar um critério subjetivo para distinguir regiões no disco (AF "externo" e AF "interno"). Nossos dados de discos lombares sugerem que o grau de degeneração seja o principal preditor das características histológicas e não a idade, mas ainda assim degeneração nos espécimes de $\underline{\text { GJ }}$ e $\underline{\text { GI }}$ apresentaram sutis diferenças já comentadas, como a questão do colabamento discal versus fissuras como determinante de gradação (Figuras 41 e $\underline{\mathbf{4 2}}$, Figuras 45 e $\underline{46}$ ). Embora os resultados de Cloyd e Elliott apontem em uma direção oposta aos resultados desta tese e do restante da literatura, como visto acima eles não são absolutamente incompativeis em virtude do exposto acima. Lembre-se ainda que os dados de Cloyd e Elliott certamente não são aplicáveis aos discos do segmento cervical, onde se demonstrou aqui definitiva diminuição do conteúdo elástico não apenas em todos os discos de $\underline{\mathbf{G I}}$ mas também em alguns não-degenerados de $\underline{\mathbf{G J}}$.

Estas alterações degenerativas dos discos intervertebrais foram analisadas pela primeira vez no segmento cervical através de MEV. Embora haja alguns trabalhos com microscopia eletrônica de transmissão, há apenas dois trabalhos publicados que aplicaram a análise de MEV ao disco intervertebral em segmento lombar: Inoue e Takeda estudaram em 1976 discos lombares de ratos, cães e humanos, servindo basicamente como demonstração do conceito que as fibrilas do AF podem ser demonstradas por MEV, e Aladin em 2009 a utilizou para analisar individualmente fibrilas colágenas ${ }^{250}$. O presente estudo consiste portanto na primeira análise sistemática dos discos humanos através de MEV, particularmente do segmento cervical. Não apenas as fibrilas do AF foram demonstradas nos discos cervicais e lombares, mas o limite AF-NP que usualmente não se distingue nos espécimes cervicais mais degenerados foi claramente demonstrado (iguras 47 e $\underline{\mathbf{4 8}}$ ). Curiosamente, uma das figuras de Inoue e Takeda demonstra o mesmo limite, embora os autores não tenham feito nenhuma correlação ou sequer a identificado ${ }^{250}$. O adensamento das fibras do AF, com a perda do espaço existente em $\underline{\mathbf{G J}}$ entre os feixes, está claramente demonstrado na comparação entre GJ e GI (Figuras $\underline{47}$ e $\underline{48}, \underline{49}$ e $\underline{\mathbf{5 0}}$ ). A delgada estrutra do NP também foi 
visualizada (Figura 49). Esta perspectiva tridimensional da estrutura discal não pode ser obtida através de secções e análise histológicas, ainda que em diferentes planos. Por exemplo, demonstra-se muito mais facilmente nas Figuras $\underline{49}$ e $\underline{\mathbf{5 0}}$ a ausência de fibras transversais ou circulares no AF do que na análise histológica, assim como a inserção oblíqua no plano sagital e predomínio de feixes longitudinais da região posterior do AF (Figuras 48B).

Um dos maiores desafios do presente trabalho foi a concepção, padronização e execução da técnica de avaliação do perfil colágeno por IHC. Como consta na Introdução, diversos autores buscaram identificar os diferentes tipos de colágeno no disco por IHC, iniciando com o estudo de Beard et al. e culminando no trabalho de Nerlich et al., que utilizou um número elevado de espécimes e testou diversos colágenos ${ }^{56,69}$. Entretanto, além dos problemas de seleção de espécimes, o método de avaliação qualitativa empregado não permite uma compreensão adequada da expressão dos diferentes tipos de colágeno: muitas das figuras de Nerlich et al. que são descritas como contendo aumento de expressão de determinado tipo de colágeno dificilmente teriam sido consideradas sequer positivas no presente estudo. Assim, buscou-se auxílio nas técnicas de processamento de imagens e tomou-se proveito dos avanços de computação e imagem digital que ocorreram a partir de meados dos anos 1990. Mosedale et al. descreveram o primeiro método de quantificação de cor, baseado em intensidade, em 1996, e Lehr et al. introduziram a quantificação baseada por área em $1999^{230,231}$. Aplicou-se aqui um método de quantificação de marcação pela primeira vez ao disco intervertebral de modo a diminuir a subjetividade na avaliação do perfil colágeno. A novidade introduzida na análise quantitativa de cromógeno foi a utilização de dois controles negativos (simples- e duplo-negativo) para contabilizar a coloração de fundo e analisá-la com testes estatísticos. Este cuidado surgiu quando da realização de pilotos com imunofluorescência, em busca de se anular a autofluorescência de fundo do disco intervertebral - após muito trabalho desperdiçado, percebeu-se que o colágeno é uma das proteínas com maior fluorescência de fundo no corpo humano. Este dado foi poucas vezes relatado na literatura ${ }^{234,235}$. Durante estes pilotos, entretanto, uma das técnicas de compensação de autofluorescência citada por Walker foi percebida como potencialmente aplicável à marcação com cromógeno - estes controles serviriam para marcar o "zero" de 
marcação por anticorpo, e diferenças entre eles mesmos permitiriam ao autor identificar a natureza da marcação anômala ${ }^{233}$.

O padrão de marcação já foi comentado extensivamente por Nerlich et al., e replicado neste estudo: houve basicamente dois padrões, um filiforme (colágenos I, II, IV, IX e X) e outro intra-/pericelular (colágenos III e VI). Não há como saber exatamente o significado destes padrões, mas a marcação filiforme poderia representar os colágenos estruturais fazendo parte dos feixes de conjuntivo, enquanto que a marcação pericelular poderia representar síntese recente ou atuação modulatória destes colágenos sobre o processo degenerativo ${ }^{56}$.

O processo de quantificação da marcação de colágeno permitiu elaborar um mapa da presença destes subtipos nos discos jovens e idosos. No segmento cervical, ficou evidente o predomínio de colágeno II em todos os setores do disco, com um componente menor de colágeno IV nos discos jovens (Figura 52). O fato de colágeno II ser o predominante não é surpreendente uma vez que é um dos colágenos característicos de tecidos cartilagíneos e foi o único colágeno cuja forma de expressão, relativamente elevada nos espécimes lombares, foi congruente nos estudos de Beard et al., Roberts et al. e Nerlich et al $\left.\right|^{56,69,86,229}$. Por outro lado, colágeno IV foi considerado como não fazendo parte de discos considerados "normais" por Roberts et al. e até mesmo um marcador intermediário de degeneração em adultos jovens por Nerlich et al ${ }^{56,86}$. Nos espécimes de Gl, esta marcação diminuiu cerca de $70 \%$ para colágeno tipo II e 50\% para tipos III e IV na região posterior, o que corresponde exatamente ao observado por Nerlich et al. para estes dois colágenos nos discos lombares desta faixa etária, embora sempre sem representação de magnitude devido ao seu método de avaliação semi-quantitativo ${ }^{56}$. A pequena expressão de colágeno tipo I também foi comum aos resultados do presente estudo. Comprova-se assim que o setor posterior do disco cervical foi submetido a um remodelamento mais extenso em termos de perfil colágeno do que o setor anterior, uma vez que colágenos II, III, IV, VI e IX estavam significativamente alterados, ao contrário da região anterior onde apenas colágenos II e VI apresentaram diferenças de marcação. 
O perfil colágeno dos discos lombares apresentou pontos em comum e também distintos com os discos do segmento cervical. Novamente colágeno tipo II foi o mais comum, ainda que em magnitude menor que nos discos cervicais e particularmente no setor posterior do $A F$, além de um importante componente de colágeno IV. Colágeno Vi também foi mais expresso nos AF lombares. O NP do segmento lombar ainda se distinguiu por exibir marcação mais acentuada para colágeno IX (igura 53). Nos espécimes idosos, todos os colágenos fibrilares estiveram expressos em menor quantidade no AF anterior; no AF posterior, colágeno II já estava mesmo em GJ em níveis comparáveis ao tipicamente idoso nos outros segmentos, e ainda apresentou redução na expressão de colágenos I e III. O NP em GI perdeu sua característica expressão mais elevada de colágeno tipo IX. Este colágeno tipicamente encontra-se ligado às moléculas de colágeno tipo II, que apresentaram também no NP redução significativa embora não tenha atingido significância estatística $(p=0,06)$. Nota-se na análise do segmento posterior dos discos lombares que o padrão de GJ é muito similar ao de GI, fato corroborado pela análise histológica: pode ser que este segmento já se encontre degenerado de maneira mais acentuada nos espécimes jovens. Uma evidência a mais para comprovar este fato é o padrão de expressão de colágeno VI. Extremamente regular em todos os outros setores discais, cervicais e lombares, a queda de sua expressão de GJ para GI foi absolutamente previsível e similar em todos os segmentos - exceto na região posterior do AF lombar, onde já se encontrava baixa em GJ e permaneceu inalterada (Figura 54).

Devido às características de seleção de nossa amostra e processo de quantificação, o presente estudo não é exatamente comparável a nenhum dos estudos mais importantes de localização de tipos de colágeno. Beard et al. (1981) possui resultados conflitantes em virtude de seu emprego de espécimes cirúrgicos e de autópsia; certamente nossos resultados não corroboram sua afirmação um tanto genérica que no segmento cervical a expressão colágena não diferiria da $\operatorname{lombar}^{69}$. Por outro lado, reforçamos os resultados de Roberts et al. e Nerlich et al. quanto à redução no conteúdo dos colágenos II e IX, e compartilhamos de sua dificuldade quanto à explicar a ausência de reatividade para 
colágeno tipo I. Diversos mecanismos foram aventados para explicar a pequena expressão de colágeno tipo I, entre eles mascaramento por fixador ou espessura de fibras, mas os resultados aqui demonstrados sugerem mais uma vez que esta expressão seria de fato pequena. Uma hipótese é que tal expressão nos estudos por autoradiografia poderia ser contaminação de fragmentos do LLA, que por macroscopia ou análise histológica comum são indistinguíveis do AF. Análise de refringência, entretanto, demonstra um padrão absolutamente distinto para esta estrutura; maior cuidado na preparação dos espécimes neste e nos outros trabalhos de imunolocalização podem ter evitado a contaminação.

Não se percebeu ainda um tipo colágeno que possa ser chamado de "marcador universal" para alterações degenerativas, como sugeriram Nerlich et al. para colágeno IV na meia-idade e colágeno $X$ na idade avançada $^{56}$. Verificou-se aqui que a expressão de colágeno IV é constitutiva do disco, enquanto que não há expressão detectável de colágeno X na maioria dos setores discais e esta tenderia a diminuir com o envelhecimento. Entretanto, reconhecese que a identificável de um marcador confiável depende não apenas de um estudo da população assintomática mas também de indivíduos sintomáticos. Assim, novos estudos em tal população são necessários para poder afirmar o papel de colágeno tipo X; o fato de sua expressão ser baixa em nossa análise o mantém como possível candidato. Houve apenas um colágeno que apresentou aumento da expressão em Gl: colágeno I, justamente no AF anterior.

É natural que colágenos fibrilares componham a maioria dos colágenos no disco intervertebral, em particular o colágeno tipo II em virtude da sua natureza cartilagínea. Além disso, colágeno tipo IX está frequentemente associado ao tipo II, portanto também se explica sua elevada expressão e poderia explicar as associações genéticas revisadas na seção 1.6.5 ${ }^{229}$. É particularmente siginificativo que das quatro associações genéticas identificadas para DDD, três dizem respeito aos genes envolvidos na síntese destes dois colágenos. Não se explica a presença de colágenos formadores de rede como colágeno tipo IV ou X, particularmente no AF, mas estes poderiam facilmente compor parte da capacidade resisitiva do $\mathrm{AF}$ às forças de cisalhamento e formar pontes entre os feixes fibrilares. 
A elaboração do perfil colágeno e compreensão de como os diferentes subtipos se relacionam só foram possíveis através do método de quantificação empregado. Sem este método, os resultados estariam dispostos como nos trabalhos de Nerlich et al. e Roberts et al., onde não se percebe diferenças entre os vários subtipos. A elaboração de um perfil colágeno de indivíduos assintomáticos permite uma futura comparação com espécimes obtidos de cirurgia e submetidos à mesma técnica. Conseguiu-se ainda desmistificar a noção que um tipo único de colágeno pode ser considerado um "marcador" degenerativo - o remodelamento degenerativo dos discos cervicais é complexo, único para cada segmento e envolve praticamente todos os colágenos em determinados setores. Estes dados fornecem, assim, uma base para estudos futuros que busquem recompor a matriz extracelular do disco intervertebral. O delineamento de sua composição em indivíduos jovens assintomáticos jovens permite traçar um "objetivo" para eventuais terapias de reconstrução discal.

Como em qualquer trabalho científico, gostaria-se de ter obtido aqui um resultado mágico ou fantástico que permitisse elucidar a fisiopatologia de um grave problema de saúde que, infelizmente, é bastante prevalente na população e tende a aumentar a medida que esta mesma população estende sua expectativa de vida. Os limitados objetivos propostos ao início deste trabalho foram alcançados, traçando um perfil morfológico do disco que pudesse servir de base para compreensão do processo de envelhecimento. Entretanto, como em tantos outros estudos, chegou-se à conclusão que mais trabalho, possivelmente envolvendo agora espécimes de indivíduos sintomáticos, é necessário. Ao invés de se sentir desapontado por esta conclusão, o autor se sente feliz por esta pequena contribuição e por perceber que não chega ao fim de uma jornada, mas ao limiar de novas possibilidades de investigação. 
6 Conclusões 
Como se depreende do exposto acima, o objetivo do presente estudo foi completamente alcançado. Os dados obtidos a partir de avaliação macroscópica, ressonância magnética, histologia, microscopia eletrônica de varredura e imuno-histoquímica permitiram a primeira descrição do perfil morfológico de discos cervicais e lombares obtidos de indivíduos indivíduos assintomáticos. Estes discos, mesmo na população jovem, já possuem alterações degenerativas significantes e passam por extenso remodelamento ao longo da vida. Estas alterações, face ao caráter assintomático dos indivíduos, não devem ser consideradas necessariamente patológicas.

Assim, as hipóteses propostas foram testadas e comprovadas:

1) Os discos intervertebrais humanos cervicais e lombares diferem em sua morfologia e composição;

2) As alterações morfológicas do proporcionadas pelo envelhecimento normal são únicas de acordo com o segmento vertebral a que determinado disco pertence. 
Referências 


\section{Referências*}

1. Coventry MB, Ghormley RK, Kernohan JW. The intervertebral disc: its microscopic anatomy and pathology. Part I: Anatomy, development and pathology. J Bone Joint Surg Am. 1945;27:105-12.

2. Rubin DI. Epidemiology and risk factors for spine pain. Neurol Clin. 2007;25(2):353-71.

3. Frymoyer JW. Back pain and sciatica. N Engl J Med. 1988 Feb 4;318(5):291-300.

4. Strine TW, Hootman JM. US national prevalence and correlates of low back and neck pain among adults. Arthritis Rheum. 2007 May;57(4):656-65.

5. Waxman R, Tennant A, Helliwell P. A prospective follow-up study of low back pain in the community. Spine. 2000 Aug 15;25(16):2085-90.

6. Cassidy JD, Côté P, Carroll LJ, Kristman V. Incidence and course of low back pain episodes in the general population. Spine. 2005 Dec 15;30(24):2817-23.

7. Kopec JA, Sayre EC, Esdaile JM. Predictors of back pain in a general population cohort. Spine. 2004 Jan 1;29(1):70-77; discussion 77-8.

8. Carragee EJ, Cohen SP. Lifetime asymptomatic for back pain: the validity of self-report measures in soldiers. Spine. 2009 Apr 20;34(9):978-83.

9. Walker BF. The prevalence of low back pain: a systematic review of the literature from 1966 to 1998. J Spinal Disord. 2000 Jun;13(3):205-17.

10. Hogg-Johnson S, van der Velde G, Carroll LJ, Holm LW, Cassidy JD, Guzman J, et al. The burden and determinants of neck pain in the general population: results of the Bone and Joint Decade 2000-2010 Task Force on Neck Pain and Its Associated Disorders. Spine. 2008 Feb 15;33(4 Suppl):S39-51.

11. Bot SDM, van der Waal JM, Terwee CB, van der Windt DAWM, Schellevis FG, Bouter LM, et al. Incidence and prevalence of complaints of the neck and upper extremity in general practice. Ann Rheum Dis. 2005 Jan;64(1):118-23.

12. Ståhl $M$, Mikkelsson $M$, Kautiainen $H$, Häkkinen $A$, Ylinen J, Salminen JJ. Neck pain in adolescence. A 4-year follow-up of pain-free preadolescents. Pain. 2004 Jul;110(1-2):427-31.

13. Côté P, Cassidy JD, Carroll L. The Saskatchewan Health and Back Pain Survey. The prevalence of neck pain and related disability in Saskatchewan adults. Spine. 1998 Aug 1;23(15):1689-98.

14. Croft PR, Lewis M, Papageorgiou AC, Thomas E, Jayson MI, Macfarlane GJ, et al. Risk factors for neck pain: a longitudinal study in the general population. Pain. 2001 Sep;93(3):317-25.

15. Hansson EK, Hansson TH. The costs for persons sick-listed more than one month because of low back or neck problems. A two-year prospective study of Swedish patients. Eur Spine J. 2005 May;14(4):337-45.

* De acordo com: International Committee of Medical Journal Editors. Uniform requirements for manuscripts submitted to biomedical journals: sample references. Available from: http://www.icmje.org [2007 May 22]. 
16. Wieser S, Horisberger B, Schmidhauser S, Eisenring C, Brügger U, Ruckstuhl A, et al. Cost of low back pain in Switzerland in 2005. Eur J Health Econ [Internet]. 2010 Jun 5;Available from: http://www.ncbi.nlm.nih.gov/pubmed/20526649 [2011 Jul 01].

17. Cassidy J, Cote P. Is It Time for a Population Health Approach to Neck Pain? Journal of Manipulative and Physiological Therapeutics. 2008 Jul;31(6):442-6.

18. Borghouts J. Cost-of-illness of neck pain in The Netherlands in 1996. Pain. 1999 Apr;80(3):629-36.

19. Harrop JS, Hanna A, Silva MT, Sharan A. Neurological manifestations of cervical spondylosis. Neurosurgery. 2007 Jan;60(Suppl):S1-14.

20. Ahn NU, Ahn UM, Ipsen B, An HS. Mechanical neck pain and cervicogenic headache. Neurosurgery. 2007 Jan;60(1 Suppl 1):S21-7.

21. Krishnaney AA, Park J, Benzel EC. Surgical management of neck and low back pain. Neurol Clin. 2007 May;25(2):507-22.

22. Harmon PH. Indications for spinal fusion in lumbar diskopathy, instability and arthrosis. I. Anatomic and functional pathology and review of literature. Clin Orthop Relat Res 1964 Jun;34:73-91.

23. Mulholland RC. The myth of lumbar instability: the importance of abnormal loading as a cause of low back pain. Eur Spine J. 2008 May;17(5):619-25.

24. Meleger AL, Krivickas LS. Neck and back pain: musculoskeletal disorders. Neurologic Clinics. 2007;25:419-38.

25. Panjabi MM. A hypothesis of chronic back pain: ligament subfailure injuries lead to muscle control dysfunction. Eur Spine J. 2005 Jul;15(5):668-76.

26. Luschka H. Die Halbegelenke des Menschlichen Körpers. 2nd ed. Berlin: Reimer; 1858.

27. Testut L. Traité D’Anatomie Humaine. Paris: Octave Doin; 1905.

28. Testut L, Jacob O. Tratado de Anatomía Topográfica con aplicacionaes médicoquirúrgicas. 5th ed. Barcelona: Salvat Editores; 1932.

29. Poirier P, Charpy A, Cunéo B. Abrégé D’Anatomie. Paris: Masson; 1908.

30. Chiarugi G. Istituzioni di Anatomia Dell'Uomo. 2nd ed. Milano: Società Editrice Libraria; 1926.

31. Sociedade Brasileira de Anatomia. Terminologia anatômica. São Paulo: Manole; 2001.

32. Hovelacque A. Le nerf sinuvertebral. Annales d'anatomie pathologique et anatomie normale. 1925;2:435-43.

33. Roofe PG. Innervation of the annulus fibrosus and posterior longitudinal ligament. Archives of Neurology and Psychiatry. 1940;44:100-3.

34. Schmorl G, Junghanns H. Die gesunde und kranke Wirbelsäule im Röntgenbild. Leipzig: Georg Thieme; 1932. 
35. Kölliker A. Ueber die Beziehungen der Chorda Dorsalis zur Bildung der Wirbelder Selachier und Einiger Andern Fische. Verhandlungen der physikalische-medikalische Gesellschaft in Wurzburg. 1860;10:193-242.

36. Löwe L. Zur Kenntniss der Saugethierchorda. Archiv fur Mikroskopische Anatomie. 1879;16:597.

37. Virchow R. Untersuchnungen über die Entwicklung des Schädelgrundes im Gesunden und Krankhaften Zustanden und über den Einfluss derselben auf Schädelform, Gesichtsbildung und Gehirnbau. Berlin: G Reimer; 1857.

38. Dursy E. Zur Entwicklungsgeschichte des Kopfes des Menschen und der Höheren Wirbeltiere. Tübingen: H Laupp; 1872.

39. Bardeen CR. The development of the thoracic vertebra in man. Am J Anat. 1905 Feb;4(2):163-74.

40. Kollmann J. Handatlas der Entwicklungsgeschichte des Menschen. Jena: G Fischer; 1907.

41. Minot CS. The segmental flexures of the notochord. Anat Rec. 1906;1:42-50.

42. Keyes DC, Compere EL. The normal and pathological physiology of the nucleus pulposus of the intervertebral disc: an anatomical, clinical and experimental study. J Bone Joint Surg Am. 1932;14:897-938.

43. Remak R. Untersuchungen über die Entwickelung der Wirbelthiere. Berlin: G. Reimer; 1855.

44. Keynes RJ, Stern CD. Mechanisms of vertebrate segmentation. Development. 1988 Jul;103(3):413-29.

45. Christ B, Wilting J. From somites to vertebral column. Ann Anat. 1992 Feb;174(1):23-32.

46. Bagnall KM, Higgins SJ, Sanders EJ. The contribution made by cells from a single somite to tissues within a body segment and assessment of their integration with similar cells from adjacent segments. Development. 1989 Dec;107(4):931-43.

47. Moore K. The developing human: clinically oriented embryology. 8th ed. Philadelphia, PA: Saunders/Elsevier; 2008.

48. Christ B, Jacob M, Jacob HJ. Results on differentiation of axis-neighbored mesoderm of young chick embryos. Verh Anat Ges. 1972;67:173.

49. Goto S, Uhthoff HK. Notochord action on spinal development. A histologic and morphometric investigation. Acta Orthop Scand. 1986 Feb;57(1):85-90.

50. Coventry MB, Ghormley RK, Kernohan JW. The intervertebral disc: its microscopic anatomy and pathology. Part II: Changes in the intervertebral disc concomitant with age. J Bone Joint Surg Am. $1945 ; 27: 233-47$.

51. Coventry MB, Ghormley RK, Kernohan JW. The intervertebral disc: its microscopic anatomy and pathology. Part III: Pathological changes in the intervertebral. J Bone Joint Surg Am. 1945;27:46074. 
52. Schleicher ED, Wagner E, Nerlich AG. Increased accumulation of the glycoxidation product $\mathrm{N}$ (epsilon)-(carboxymethyl)lysine in human tissues in diabetes and aging. J Clin Invest. 1997 Feb $1 ; 99(3): 457-68$.

53. Boos N, Weissbach S, Rohrbach H, Weiler C, Spratt KF, Nerlich AG. Classification of age-related changes in lumbar intervertebral discs: 2002 Volvo Award in basic science. Spine. 2002 Dec $1 ; 27(23): 2631-44$.

54. Haas SL. Growth in length of the vertebrae. Archives of Surgery. 1939;38(2):245-49.

55. Mau C. Der roentgenologische Nachweis der traumatischen Knorpelknötchenbildung am Wilberkörper. Zentralbl Chir. 1928;55:386.

56. Nerlich AG, Schleicher ED, Boos N. 1997 Volvo Award Winner in Basic Science Studies: Immunohistologic markers for age-related changes of human lumbar intervertebral discs. Spine. 1997;22(24):2781-95.

57. Grignon B, Roland J. Can the human intervertebral disc be compared to a diarthrodial joint? Surg Radiol Anat. 2000;22(2):101-5.

58. Übermuth H. Altersverändungen der menschlichen Bandscheiben in der Wirbelsäule. Archiv der klinische Chirurgie. 1930;156:567-77.

59. Scott JE, Bosworth TR, Cribb AM, Taylor JR. The chemical morphology of age-related changes in human intervertebral disc glycosaminoglycans from cervical, thoracic and lumbar nucleus pulposus and annulus fibrosus. J Anat. 1994;184 (Pt 1):73-82.

60. Singh K, Masuda K, Thonar EJ, An HS, Cs-Szabo G. Age-related changes in the extracellular matrix of nucleus pulposus and anulus fibrosus of human intervertebral disc. Spine. 2009;34(1):10-6.

61. Püschel J. Der Wassergehalt normalen und degenerierter Zwischenwirbelscheiben. Beiträge zur patogischen Anatomie und zur allgemeinen Pathologie. 1930;84:123-30.

62. Eckert C, Decker A. Pathological studies of intervertebral discs. J Bone Joint Surg Am. 1947;29:447-54.

63. Scott JE, Bosworth TR, Cribb AM, Gressner AM. The chemical morphology of extracellular matrix in experimental rat liver fibrosis resembles that of normal developing connective tissue. Virchows Arch. 1994;424(1):89-98.

64. Hallen A. The collagen and ground substance of human intervertebral disc at different ages. Acta Chemica Scandinavica. 1962;16:705-10.

65. Taylor JR, Scott JE, Cribb AM, Bosworth TR. Human intervertebral disc acid glycosaminoglycans. J Anat. 1992 Feb;180 ( Pt 1):137-41.

66. Adams P, Muir H. Qualitative changes with age of proteoglycans of human lumbar discs. Ann Rheum Dis. 1976 Aug;35(4):289-96.

67. Svensson L, Aszódi A, Reinholt FP, Fässler R, Heinegård D, Oldberg A. Fibromodulin-null mice have abnormal collagen fibrils, tissue organization, and altered lumican deposition in tendon. J Biol Chem. 1999 Apr 2;274(14):9636-47. 
68. Sjöberg A, Onnerfjord $P$, Mörgelin $M$, Heinegård D, Blom AM. The extracellular matrix and inflammation: fibromodulin activates the classical pathway of complement by directly binding C1q. J Biol Chem. 2005 Sep 16;280(37):32301-8.

69. Beard HK, Roberts S, O'Brien JP. Immunofluorescent staining for collagen and proteoglycan in normal and scoliotic intervertebral discs. J Bone Joint Surg Br. 1981;63B(4):529-34.

70. Naylor A, Happey F, MacRae T. The collagenous changes in the intervertebral disk with age and their effect on its elasticity; an x-ray crystallographic study. Br Med J. 1954 Sep 4;2(4887):570-3.

71. Horton WG. Further observations on the elastic mechanism of the intervertebral disc. J Bone Joint Surg Br. 1958 Aug;40-B(3):552-7.

72. Rocca-Rossetti S, Bisogno EM. Brief note on the structure of the intervertebral disk studied by the electron microscope. Rass Med Sarda. 1960 Jun;62:373-8.

73. Happey F, Johnson AG, Naylor A, Turner RL. Preliminary observations concerning the fine structure of the intervertebral disc. J Bone Joint Surg Br. 1964 Aug;46:563-7.

74. Eyre DR, Muir H. Collagen polymorphism: two molecular species in pig intervertebral disc. FEBS Lett. 1974 Jun 1;42(2):192-6.

75. Remberger K, Gay S, Adelmann BC. Age dependant differences of localisation and distribution of collagen type I, II and III in human tissues. Verh Dtsch Ges Pathol. 1975;59:276-80.

76. Junqueira LC, Cossermelli W, Brentani R. Differential staining of collagens type I, II and III by Sirius Red and polarization microscopy. Arch Histol Jpn. 1978;41(3):267-74.

77. Montes GS. Structural biology of the fibres of the collagenous and elastic systems. Cell Biol Int. 1996 Jan;20(1):15-27.

78. Ayad S, Abedin MZ, Grundy SM, Weiss JB. Isolation and characterisation of an unusual collagen from hyaline cartilage and intervertebral disc. FEBS Lett. 1981 Jan 26;123(2):195-9.

79. Ayad S, Abedin MZ, Weiss JB, Grundy SM. Characterisation of another short-chain disulphidebonded collagen from cartilage, vitreous and intervertebral disc. FEBS Lett. 1982 Mar $22 ; 139(2): 300-4$.

80. Lu Z, Hu Y, Feng C. Gene expression of fibrous main collagen in the lumbar disc. Zhonghua Wai Ke Za Zhi. 1998 Feb;36(2):68-71.

81. Montes GS, Krisztán RM, Junqueira LC. Preservation of elastic system fibers and of collagen molecular arrangement and stainability in an Egyptian mummy. Histochemistry. 1985;83(2):1179.

82. Wilke HJ, Kettler A, Wenger $\mathrm{KH}$, Claes LE. Anatomy of the sheep spine and its comparison to the human spine. Anat Rec. 1997 Apr;247(4):542-5.

83. Melrose J, Smith SM, Appleyard RC, Little CB. Aggrecan, versican and type VI collagen are components of annular translamellar crossbridges in the intervertebral disc. Eur Spine J. 2007 Oct;17(2):314-24. 
84. Eyre DR, Muir H. Types I and II collagens in intervertebral disc. Interchanging radial distributions in annulus fibrosus. Biochem J. 1976 Jul 1;157(1):267-70.

85. Roberts S, Menage J, Urban JP. Biochemical and structural properties of the cartilage end-plate and its relation to the intervertebral disc. Spine. 1989;14(2):166-74.

86. Roberts S, Menage J, Duance V, Wotton S, Ayad S. 1991 Volvo Award in basic sciences. Collagen types around the cells of the intervertebral disc and cartilage end plate: an immunolocalization study. Spine. 1991 Sep;16(9):1030-8.

87. Sive JI, Baird P, Jeziorsk M, Watkins A, Hoyland JA, Freemont AJ. Expression of chondrocyte markers by cells of normal and degenerate intervertebral discs. Mol Pathol. 2002 Apr;55(2):91-7.

88. Nerlich AG, Boos N, Wiest I, Aebi M. Immunolocalization of major interstitial collagen types in human lumbar intervertebral discs of various ages. Virchows Arch. 1998 Jan;432(1):67-76.

89. Freemont AJ. The cellular pathobiology of the degenerate intervertebral disc and discogenic back pain. Rheumatology (Oxford). 2009 Jan;48(1):5-10.

90. Harris RI, MacNab I. Structural changes in the lumbar intervertebral discs; their relationship to low back pain and sciatica. J Bone Joint Surg Br. 1954 May;36-B(2):304-22.

91. Modic MT, Ross JS. Lumbar degenerative disk disease. Radiology. 2007 Oct;245(1):43-61.

92. Adams MA, Roughley PJ. What is intervertebral disc degeneration, and what causes it? Spine. 2006 Aug 15;31(18):2151-61.

93. Fardon DF, Milette PC. Nomenclature and classification of lumbar disc pathology. Recommendations of the Combined task Forces of the North American Spine Society, American Society of Spine Radiology, and American Society of Neuroradiology. Spine. 2001 Mar 1;26(5):E93-E113.

94. Böhmig R. Die Blutgefassversorgung der Wirbelbandscheiben, das Verhalten des intervertebralen Chordasegments. Archiv für klinische Chirurgie. 1930;158:374-424.

95. Grunhagen T. Nutrient Supply and Intervertebral Disc Metabolism. J Bone Joint Surg Am. 2006 Apr;88(Supplement 2):30-5.

96. Weiler C, Nerlich AG, Zipperer J, Bachmeier BE, Boos N. 2002 SSE Award Competition in Basic Science: expression of major matrix metalloproteinases is associated with intervertebral disc degradation and resorption. Eur Spine J. 2002 Aug;11(4):308-20.

97. Goupille P, Jayson MI, Valat JP, Freemont AJ. Matrix metalloproteinases: the clue to intervertebral disc degeneration? Spine. 1998 Jul 15;23(14):1612-26.

98. Kang JD, Georgescu HI, McIntyre-Larkin L, Stefanovic-Racic M, Donaldson WF, Evans CH. Herniated lumbar intervertebral discs spontaneously produce matrix metalloproteinases, nitric oxide, interleukin-6, and prostaglandin E2. Spine. 1996 Feb 1;21(3):271-7.

99. Kang JD, Georgescu HI, McIntyre-Larkin L, Stefanovic-Racic M, Evans CH. Herniated cervical intervertebral discs spontaneously produce matrix metalloproteinases, nitric oxide, interleukin-6, and prostaglandin E2. Spine. 1995 Nov 15;20(22):2373-8. 
100. Roberts S, Eisenstein SM, Menage J, Evans EH, Ashton IK. Mechanoreceptors in intervertebral discs. Morphology, distribution, and neuropeptides. Spine. 1995 Dec 15;20(24):2645-51.

101. Weiler C, Nerlich AG, Bachmeier BE, Boos N. Expression and distribution of tumor necrosis factor alpha in human lumbar intervertebral discs: a study in surgical specimen and autopsy controls. Spine. 2005 Jan 1;30(1):44-53; discussion 54.

102. Roberts S, Caterson B, Menage J, Evans EH, Jaffray DC, Eisenstein SM. Matrix metalloproteinases and aggrecanase: their role in disorders of the human intervertebral disc. Spine. 2000 Dec 1;25(23):3005-13.

103. Aebi M, Arlet V, Webb JK. AOSpine manual. Stuttgart: AOSpine International; 2007.

104. Igarashi T, Kikuchi S, Shubayev V, Myers RR. 2000 Volvo Award winner in basic science studies: Exogenous tumor necrosis factor-alpha mimics nucleus pulposus-induced neuropathology. Molecular, histologic, and behavioral comparisons in rats. Spine. 2000 Dec 1;25(23):2975-80.

105. Bachmeier BE, Nerlich AG, Weiler C, Paesold G, Jochum M, Boos N. Analysis of Tissue Distribution of TNF-, TNF--Receptors, and the Activating TNF- -Converting Enzyme Suggests Activation of the TNF- System in the Aging Intervertebral Disc. Annals of the New York Academy of Sciences. 2007 Jan;1096(1):44-54.

106. Burke JG, Watson RWG, McCormack D, Dowling FE, Walsh MG, Fitzpatrick JM. Intervertebral discs which cause low back pain secrete high levels of proinflammatory mediators. J Bone Joint Surg Br. 2002 Mar;84(2):196-201.

107. Specchia N, Pagnotta A, Toesca A, Greco F. Cytokines and growth factors in the protruded intervertebral disc of the lumbar spine. Eur Spine J. 2002 Apr;11(2):145-51.

108. Nerlich AG, Bachmeier BE, Boos N. Expression of fibronectin and TGF-beta1 mRNA and protein suggest altered regulation of extracellular matrix in degenerated disc tissue. Eur Spine J. 2005 Feb;14(1):17-26.

109. Le Maitre C, Hoyland J, Freemont AJ. Catabolic cytokine expression in degenerate and herniated human intervertebral discs: IL-1 $\beta$ and TNF $\alpha$ expression profile. Arth Res Ther. 2007;9(4):R77.

110. Koike $Y$, Uzuki M, Kokubun S, Sawai T. Angiogenesis and inflammatory cell infiltration in lumbar disc herniation. Spine. 2003 Sep 1;28(17):1928-33.

111. Lee JM, Song JY, Baek $M$, Jung $H-Y$, Kang $H$, Han IB, et al. Interleukin-1beta induces angiogenesis and innervation in human intervertebral disc degeneration. J Orthop Res [Internet]. 2010 Aug 5;Available from: http://www.ncbi.nlm.nih.gov/pubmed/20690185 [2011 Jul 01].

112. Salo J, Kaigle Holm A, Indahl A, Mackiewicz Z, Sukura A, Holm S, et al. Expression of vascular endothelial growth factor receptors coincide with blood vessel in-growth and reactive bone remodelling in experimental intervertebral disc degeneration. Clin Exp Rheumatol. 2008 Dec;26(6):1018-26.

113. Leriche R. Recherches sur le Rôle de I'Innervation Sensitive des Articulations et de Leur Appareil Ligamentaire dans la Physiologie Articulaire. Presse Medicale.1930;38:417. 
114. Bogduk N, Tynan W, Wilson AS. The nerve supply to the human lumbar intervertebral discs. J Anat. 1981 Jan;132(Pt 1):39-56.

115. Seaman DR. Mechanoreceptors in intervertebral discs. Spine. 1996 Jul 1;21(13):1609-10.

116. Grönblad M, Weinstein JN, Santavirta S. Immunohistochemical observations on spinal tissue innervation. A review of hypothetical mechanisms of back pain. Acta Orthop Scand. 1991 Dec;62(6):614-22.

117. Korkala O, Grönblad M, Liesi P, Karaharju E. Immunohistochemical demonstration of nociceptors in the ligamentous structures of the lumbar spine. Spine. 1985 Mar;10(2):156-7.

118. Liesi P, Grönblad M, Korkala O, Karaharju E, Rusanen M. Substance P: a neuropeptide involved in low back pain? Lancet. 1983 Jun 11;1(8337):1328-9.

119. Weinstein J, Claverie W, Gibson S. The pain of discography. Spine. 1988 Dec;13(12):1344-8.

120. McCarthy PW, Carruthers B, Martin D, Petts P. Immunohistochemical demonstration of sensory nerve fibres and endings in the intervertebral discs of the rat. Spine. 1991;16:653-5.

121. Freemont AJ, Peacock TE, Goupille P, Hoyland JA, O’Brien J, Jayson MI. Nerve ingrowth into diseased intervertebral disc in chronic back pain. Lancet. 1997 Jul 19;350(9072):178-81.

122. Freemont AJ, Watkins A, Le Maitre C, Baird P, Jeziorska M, Knight MTN, et al. Nerve growth factor expression and innervation of the painful intervertebral disc. J Pathol. 2002 Jul;197(3):28692.

123. Purmessur D, Freemont AJ, Hoyland JA. Expression and regulation of neurotrophins in the nondegenerate and degenerate human intervertebral disc. Arth Res Ther. 2008;10(4):R99.

124. Uchiyama Y, Cheng C-C, Danielson KG, Mochida J, Albert TJ, Shapiro IM, et al. Expression of Acid-Sensing Ion Channel 3 (ASIC3) in Nucleus Pulposus Cells of the Intervertebral Disc Is Regulated by p75NTR and ERK Signaling. J Bone Miner Res. 2007 Aug;22(12):1996-2006.

125. Gruber HE, Ingram JA, Hoelscher G, Zinchenko N, Norton HJ, Hanley EN. Brain-derived neurotrophic factor and its receptor in the human and the sand rat intervertebral disc. Arth Res Ther. 2008;10(4):R82.

126. Manchikanti L, Singh V, Pampati V, Damron KS, Barnhill RC, Beyer C, et al. Evaluation of the relative contributions of various structures in chronic low back pain. Pain Physician. 2001 Oct;4(4):308-16.

127. Schliessbach J, Arendt-Nielsen L, Heini P, Curatolo M. The role of central hypersensitivity in the determination of intradiscal mechanical hyperalgesia in discogenic pain. Pain Med. 2010 May;11(5):701-8.

128. Cohen SP, Raja SN. Pathogenesis, diagnosis, and treatment of lumbar zygoapophysial (facet) joint pain. Anesthesiology. 2007;106:591-614.

129. Schwarzer AC, Aprill CN, Derby R, Fortin J, Kine G, Bogduk N. The relative contributions of the disc and zygapophyseal joint in chronic low back pain. Spine. 1994 Apr 1;19(7):801-6. 
130. Schmorl C, Junghanns H. Die gesunde und kranke Wirbelsäule in Röntgenbild und Klinik. 5th ed. Stuttgart: Thieme; 1968.

131. Kirkaldy-Willis WH, Wedge JH, Yong-Hing K, Reilly J. Pathology and pathogenesis of lumbar spondylosis and stenosis. Spine. 1978 Dec;3(4):319-28.

132. Yong-Hing K, Kirkaldy-Willis WH. The pathophysiology of degenerative disease of the lumbar spine. Orthop Clin North Am. 1983 Jul;14(3):491-504.

133. Cloward RB. Changes in the vertebra caused by ruptured intervertebral discs; observations on their formation and treatment. Am J Surg 1952 Aug;84(2):151-60.

134. Cavanaugh JM, Ozaktay AC, Yamashita HT, King Al. Lumbar facet pain: biomechanics, neuroanatomy and neurophysiology. Journal of Biomechanics. 1996;29:1117-29.

135. Cavanaugh JM, Ozaktay AC, Yamashita T, Avramov A, Getchell TV, King Al. Mechanisms of low back pain: a neurophysiologic and neuroanatomic study. Clinical Orthopedics and Related Research. 1997;335:166-80.

136. Fujiwara A, Tamai K, Yamato M, An HS, Yoshida H, Saotome K, et al. The relationship between facet joint osteoarthritis and disc degeneration of the lumbar spine: an MRI study. Eur Spine J. 1999;8(5):396-401.

137. Butler D, Trafimow JH, Andersson GB, McNeill TW, Huckman MS. Discs degenerate before facets. Spine. 1990 Feb;15(2):111-3.

138. Goel VK, Kong W, Han JS, Weinstein JN, Gilbertson LG. A combined finite element and optimization investigation of lumbar spine mechanics with and without muscles. Spine. 1993 Sep 1;18(11):1531-41.

139. Boden SD, Davis DO, Dina TS, Patronas NJ, Wiesel SW. Abnormal magnetic-resonance scans of the lumbar spine in asymptomatic subjects. A prospective investigation. J Bone Joint Surg Am. 1990 Mar;72(3):403-8.

140. Boden SD, McCowin PR, Davis DO, Dina TS, Mark AS, Wiesel S. Abnormal magnetic-resonance scans of the cervical spine in asymptomatic subjects. A prospective investigation. J Bone Joint Surg Am. 1990 Sep;72(8):1178-84.

141. Boos N, Rieder R, Schade V, Spratt KF, Semmer N, Aebi M. 1995 Volvo Award in clinical sciences. The diagnostic accuracy of magnetic resonance imaging, work perception, and psychosocial factors in identifying symptomatic disc herniations. Spine. 1995 Dec 15;20(24):2613-25.

142. Schmorl CG. Uber Knorpel Knotchen an der Hinterflache der Wirbelbandscheiben. Fortschritte an den Gebiete der Röntgenstrahlen. 1929;40:629-34.

143. Lindblom K. Diagnostic puncture of intervertebral disks in sciatica. Acta Orthop Scand. 1948;17(3-4):231-9.

144. Raney AA, Raney RB, Hunter CR. Chronic posttraumatic headache and the syndrome of cervical disc lesion following head trauma. J Neurosurg. 1949 Nov;6(6):458-65. 
145. Cloward RB. Cervical diskography. A contribution to the etiology and mechanism of neck, shoulder and arm pain. Ann Surg. 1959;150:1052-64.

146. Cloward RB. The treatment of ruptured lumbar intervertebral discs by vertebral body fusion. I. Indications, operative technique, after care. J Neurosurg. 1953 Mar;10(2):154-68.

147. Zhou $Y$, Abdi S. Diagnosis and minimally invasive treatment of lumbar discogenic pain--a review of the literature. Clin J Pain. 2006 Jun;22(5):468-81.

148. Crock HV. A reappraisal of intervertebral disc lesions. Med J Aust. 1970 May 16;1(20):983-9.

149. Manchikanti L, Singh V, Datta S, Cohen SP, Hirsch JA. Comprehensive review of epidemiology, scope, and impact of spinal pain. Pain Physician. 2009 Aug;12(4):E35-70.

150. Manchikanti L, Dunbar EE, Wargo BW, Shah RV, Derby R, Cohen SP. Systematic review of cervical discography as a diagnostic test for chronic spinal pain. Pain Physician. 2009;12(2):30521.

151. Manchikanti L, Glaser SE, Wolfer L, Derby R, Cohen SP. Systematic review of lumbar discography as a diagnostic test for chronic low back pain. Pain Physician. 2009 Jun;12(3):541-59.

152. Manchikanti L, Derby R, Benyamin RM, Helm S, Hirsch JA. A systematic review of mechanical lumbar disc decompression with nucleoplasty. Pain Physician. 2009 Jun;12(3):561-72.

153. Wolfer L, Carragee E, Akuthota V. Lumbar provocation diskography: helpful or harmful? PM R. 2010 Oct;2(10):957-68.

154. Hestbaek L, lachine IA, Leboeuf-Yde C, Kyvik KO, Manniche C. Heredity of low back pain in a young population: a classical twin study. Twin Res. 2004 Feb;7(1):16-26.

155. Gruber HE, Hoelscher GL, Hanley EN. Annulus cells from more degenerated human discs show modified gene expression in 3D culture compared with expression in cells from healthier discs. Spine J. 2010 Aug;10(8):721-27.

156. Chan D, Song Y, Sham P, Cheung KMC. Genetics of disc degeneration. Eur Spine J. 2006 Aug;15 Suppl 3:S317-25.

157. Annunen S, Paassilta P, Lohiniva J, Perälä M, Pihlajamaa T, Karppinen J, et al. An allele of COL9A2 associated with intervertebral disc disease. Science. 1999 Jul 16;285(5426):409-12.

158. Kalichman L, Hunter DJ. The genetics of intervertebral disc degeneration. Associated genes. Joint Bone Spine. 2008 Jul;75(4):388-96.

159. Boyd LM, Richardson WJ, Allen KD, Flahiff C, Jing L, Li Y, et al. Early-onset degeneration of the intervertebral disc and vertebral end plate in mice deficient in type IX collagen. Arth Rheum. 2008 Jan;58(1):164-71.

160. Kimura T, Nakata K, Tsumaki N, Miyamoto S, Matsui Y, Ebara S, et al. Progressive degeneration of articular cartilage and intervertebral discs. An experimental study in transgenic mice bearing a type IX collagen mutation. Int Orthop. 1996;20(3):177-81. 
161. Karppinen J, Pääkkö E, Räinä S, Tervonen $O$, Kurunlahti $M$, Nieminen $P$, et al. Magnetic resonance imaging findings in relation to the COL9A2 tryptophan allele among patients with sciatica. Spine. 2002 Jan 1;27(1):78-83.

162. Jim JJT, Noponen-Hietala N, Cheung KMC, Ott J, Karppinen J, Sahraravand A, et al. The TRP2 allele of COL9A2 is an age-dependent risk factor for the development and severity of intervertebral disc degeneration. Spine. 2005 Dec 15;30(24):2735-42.

163. Wrocklage C, Wassmann H, Paulus W. COL9A2 allelotypes in intervertebral disc disease. Biochem Biophys Res Commun. 2000 Dec 20;279(2):398-400.

164. Seki S, Kawaguchi Y, Mori M, Mio F, Chiba K, Mikami Y, et al. Association study of COL9A2 with lumbar disc disease in the Japanese population. J Hum Genet. 2006;51(12):1063-7.

165. Pluijm SMF, van Essen HW, Bravenboer N, Uitterlinden AG, Smit JH, Pols HAP, et al. Collagen type I alpha1 Sp1 polymorphism, osteoporosis, and intervertebral disc degeneration in older men and women. Ann Rheum Dis. 2004 Jan;63(1):71-7.

166. Tilkeridis C, Bei T, Garantziotis S, Stratakis CA. Association of a COL1A1 polymorphism with lumbar disc disease in young military recruits. J Med Genet. 2005 Jul;42(7):e44.

167. Jones $G$, White $C$, Sambrook P, Eisman J. Allelic variation in the vitamin D receptor, lifestyle factors and lumbar spinal degenerative disease. Ann Rheum Dis. 1998 Feb;57(2):94-9.

168. Kawaguchi $\mathrm{Y}$, Kanamori M, Ishihara H, Ohmori K, Matsui H, Kimura T. The association of lumbar disc disease with vitamin-D receptor gene polymorphism. J Bone Joint Surg Am. 2002 Nov;84-A(11):2022-8.

169. Videman T, Gibbons LE, Battié MC, Maravilla K, Vanninen E, Leppävuori J, et al. The relative roles of intragenic polymorphisms of the vitamin $d$ receptor gene in lumbar spine degeneration and bone density. Spine. 2001 Feb 1;26(3):E7-E12.

170. Videman T, Leppävuori J, Kaprio J, Battié MC, Gibbons LE, Peltonen L, et al. Intragenic polymorphisms of the vitamin $\mathrm{D}$ receptor gene associated with intervertebral disc degeneration. Spine. 1998 Dec 1;23(23):2477-85.

171. Cheung KMC, Chan D, Karppinen J, Chen Y, Jim JJT, Yip S-P, et al. Association of the Taq I allele in vitamin $\mathrm{D}$ receptor with degenerative disc disease and disc bulge in a Chinese population. Spine. 2006 May 1;31(10):1143-8.

172. Takahashi M, Haro H, Wakabayashi Y, Kawa-uchi T, Komori H, Shinomiya K. The association of degeneration of the intervertebral disc with $5 a / 6$ a polymorphism in the promoter of the human matrix metalloproteinase-3 gene. J Bone Joint Surg Br. 2001 May;83(4):491-5.

173. Valdes AM, Hassett G, Hart DJ, Spector TD. Radiographic progression of lumbar spine disc degeneration is influenced by variation at inflammatory genes: a candidate SNP association study in the Chingford cohort. Spine. 2005 Nov 1;30(21):2445-51.

174. Noponen-Hietala N, Kyllönen E, Männikkö M, llkko E, Karppinen J, Ott J, et al. Sequence variations in the collagen IX and $\mathrm{XI}$ genes are associated with degenerative lumbar spinal stenosis. Ann. Rheum. Dis. 2003 Dec;62(12):1208-14. 
175. An HS, Masuda K. Relevance of in vitro and in vivo models for intervertebral disc degeneration. J Bone Joint Surg Am. 2006 Apr;88 Suppl 2:88-94.

176. Osti OL, Fraser RD. MRI and discography of annular tears and intervertebral disc degeneration. A prospective clinical comparison. J Bone Joint Surg Br. 1992 May;74(3):431-5.

177. Alini M, Eisenstein SM, Ito K, Little C, Kettler AA, Masuda K, et al. Are animal models useful for studying human disc disorders/degeneration? Eur Spine J. 2007 Jul;17(1):2-19.

178. Silberberg R, Aufdermaur M, Adler JH. Degeneration of the intervertebral disks and spondylosis in aging sand rats. Arch Pathol Lab Med. 1979 May;103(5):231-5.

179. Gruber HE, Johnson TL, Leslie K, Ingram JA, Martin D, Hoelscher G, et al. Autologous intervertebral disc cell implantation: a model using Psammomys obesus, the sand rat. Spine. 2002 Aug 1;27(15):1626-33.

180. Cole TC, Ghosh P, Taylor TK. Variations of the proteoglycans of the canine intervertebral disc with ageing. Biochim Biophys Acta. 1986 Feb 19;880(2-3):209-19.

181. Lauerman WC, Platenberg RC, Cain JE, Deeney VF. Age-related disk degeneration: preliminary report of a naturally occurring baboon model. J Spinal Disord. 1992 Jun;5(2):170-4.

182. Kellgren JH, Lawrence JS. Osteo-arthrosis and disk degeneration in an urban population. Ann Rheum Dis. 1958 Dec;17(4):388-97.

183. Modic MT, Pavlicek W, Weinstein MA, Boumphrey F, Ngo F, Hardy R, et al. Magnetic resonance imaging of intervertebral disk disease. Clinical and pulse sequence considerations. Radiology. 1984 Jul;152(1):103-11.

184. Modic MT. Degenerative disc disease and back pain. Magn Reson Imaging Clin N Am. 1999 Aug;7(3):481-91.

185. Matsumoto M, Fujimura Y, Suzuki N, Nishi Y, Nakamura M, Yabe Y, et al. MRI of cervical intervertebral discs in asymptomatic subjects. J Bone Joint Surg Br. 1998 Jan;80(1):19-24.

186. Lehto IJ, Tertti MO, Komu ME, Paajanen HE, Tuominen J, Kormano MJ. Age-related MRI changes at $0.1 \mathrm{~T}$ in cervical discs in asymptomatic subjects. Neuroradiology. 1994;36(1):49-53.

187. Okada E, Matsumoto M, Ichihara D, Chiba K, Toyama Y, Fujiwara H, et al. Aging of the cervical spine in healthy volunteers: a 10-year longitudinal magnetic resonance imaging study. Spine. 2009;34(7):706-12.

188. Matsumoto M, Okada E, Ichihara D, Watanabe K, Chiba K, Toyama Y, et al. Age-related changes of thoracic and cervical intervertebral discs in asymptomatic subjects. Spine. 2010 Jun $15 ; 35(14): 1359-64$.

189. Mercer S, Bogduk N. The ligaments and annulus fibrosus of human adult cervical intervertebral discs. Spine. 1999;24(7):619-28.

190. Connell MD, Wiesel SW. Natural history and pathogenesis of cervical disk disease. Orthop Clin North Am. 1992 Jul;23(3):369-80. 
191. Gruber HE, Hanley EN. Ultrastructure of the human intervertebral disc during aging and degeneration: comparison of surgical and control specimens. Spine. 2002 Apr 15;27(8):798-805.

192. Kanemoto M, Hukuda S, Komiya Y, Katsuura A, Nishioka J. Immunohistochemical study of matrix metalloproteinase-3 and tissue inhibitor of metalloproteinase-1 human intervertebral discs. Spine. 1996 Jan 1;21(1):1-8.

193. Scoville WB. Types of cervical disk lesions and their surgical approaches. JAMA. 1966 May 9;196(6):479-81.

194. Töndury G. La colonne cervicale, son développement et ses modifications durant la vie. Acta Orthopaedica Belgica. 1959;25:602-27.

195. Töndury G. Some remarks on the anatomy and pathological anatomy of the cervical spine. Acta Chir Belg. 1961 Jun;60:567-81.

196. Pooni JS, Hukins DW, Harris PF, Hilton RC, Davies KE. Comparison of the structure of human intervertebral discs in the cervical, thoracic and lumbar regions of the spine. Surg Radiol Anat. 1986;8(3):175-82.

197. Oda J, Tanaka H, Tsuzuki N. Intervertebral disc changes with aging of human cervical vertebra. From the neonate to the eighties. Spine. 1988 Nov;13(11):1205-11.

198. Bland JH, Boushey DR. Anatomy and physiology of the cervical spine. Semin Arthritis Rheum. 1990 Aug;20(1):1-20.

199. Hirsch C, Schajowicz R, Galante J. Structural changes in the cervical spine. A study on autopsy specimens in different age groups. Acta Orthop Scand. 1967;:Suppl 109:7-77.

200. Kolstad F, Myhr G, Kvistad KA, Nygaard OP, Leivseth G. Degeneration and height of cervical discs classified from MRI compared with precise height measurements from radiographs. Eur J Radiol. 2005 Sep;55(3):415-20.

201. Furusawa N, Baba H, Miyoshi N, Maezawa Y, Uchida K, Kokubo Y, et al. Herniation of cervical intervertebral disc: immunohistochemical examination and measurement of nitric oxide production. Spine. 2001 May 15;26(10):1110-6.

202. Kokubo Y, Uchida K, Kobayashi S, Yayama T, Sato R, Nakajima H, et al. Herniated and spondylotic intervertebral discs of the human cervical spine: histological and immunohistological findings in 500 en bloc surgical samples. Laboratory investigation. J Neurosurg Spine. 2008;9(3):285-95.

203. Christe A, Läubli R, Guzman R, Berlemann U, Moore RJ, Schroth G, et al. Degeneration of the cervical disc: histology compared with radiography and magnetic resonance imaging. Neuroradiology. 2005 Sep;47(10):721-9.

204. Maruyama Y. Histological, magnetic resonance imaging, and discographic findings on cervical disc degeneration in cadaver spines: a comparative study. Nippon Seikeigeka Gakkai Zasshi. 1995 Nov;69(11):1102-12.

205. Gen H. A clinicopathological study of cervical intervertebral discs--Part 1: On histopathological findings. Nippon Seikeigeka Gakkai Zasshi. 1990 Jul;64(7):560-71. 
206. Gen H. A clinicopathological study of cervical intervertebral discs--Part 2: On morphological and roentgenologic findings. Nippon Seikeigeka Gakkai Zasshi. 1990 Jul;64(7):572-82.

207. Hirsch C, Schajowicz F. Studies on structural changes in the lumbar annulus fibrosus. Acta Orthop Scand. 1953;22(3):184-231.

208. Buckwalter JA, Cooper RR, Maynard JA. Elastic fibers in human intervertebral discs. J Bone Joint Surg Am. 1976 Jan;58(1):73-6.

209. Johnson EF, Chetty K, Moore IM, Stewart A, Jones W. The distribution and arrangement of elastic fibres in the intervertebral disc of the adult human. J Anat. 1982 Sep;135(Pt 2):301-9.

210. Nunes F, Conforti-Froes N, Negrelli W, Souza D. Fatores genéticos e ambientais envolvidos na degeneração do disco intervertebral. Acta Ortop Bras. 2007;15(1):9-13.

211. Oliveira VM de, Puertas EB, Alves MT de S, Yamashita HK. Estudo comparativo dos mecanorreceptores dos discos intervertebrais normais e degenerados da coluna lombar de humanos pela radiografia, ressonância magnética e estudo anatomopatológico. Acta Ortop Bras. [Internet]. 2007;15(1). Available from: http://www.scielo.br/scielo.php?script=sci_arttext\&pid=S1413$78522007000100007 \& \operatorname{lng}=p t \& n r m=i s o \& t$ Ing=pt [2011 Jul 01].

212. Vialle $E$, Vialle $L R$, Arruda $A$ de $O$, Riet $R N$, Krieger $A B$ de $Q$. Análise radiológica da degeneração discal experimental em coelhos. Rev Bras Ortop. [Internet]. 2009;44(4). Available from: $\quad$ http://www.scielo.br/scielo.php?script=sci_arttext\&pid=S0102$36162009000400005 \& \operatorname{lng}=p t \& n r m=$ iso\&tlng=pt [2011 Jul 01].

213. Martins DE, Oliveira VM de, Alves MT de S, Wajchenberg M, Landim E, Belloti JC, et al. Correlations between radiographic, magnetic resonance and histological examinations on the degeneration of human lumbar intervertebral discs. Sao Paulo Med J. 2010;128(2):63-8.

214. Schechtman $\mathrm{H}$, Robertson PA, Broom ND. Failure strength of the bovine caudal disc under internal hydrostatic pressure. J Biomech. 2006;39(8):1401-9.

215. Puertas EB, Yamashita H, Oliveira VM de, Souza PS de. Classificação por ressonância magnética da degeneração do disco intervertebral. Acta Ortop Bras. [Internet]. 2009;17(1). Available from: http://www.scielo.br/scielo.php?script=sci_arttext\&pid=S141378522009000100009\&Ing=pt\&nrm=iso\&tlng=pt [2011 Jul 01].

216. Maurer M, Soder RB, Baldisserotto M. Spine Abnormalities Depicted by Magnetic Resonance Imaging in Adolescent Rowers. Am J Sports Med [Internet]. 2010 Oct 2;Available from: http://www.ncbi.nlm.nih.gov/pubmed/20889986 [2011 Jul 01].

217. Vieira JSL, Herrero CFPS, Porto MA, Barbosa MHN, Garcia SB, Ramalho LNZ, et al. Avaliação da placa vertebral terminal na coluna cervical em diferentes faixas etárias e sua correlação com a espessura do disco intervertebral. Rev Bras Ortop. 2009;44(1):20-5.

218. Kettler A, Wilke HJ. Review of existing grading systems for cervical or lumbar disc and facet joint degeneration. Eur Spine J. 2006;15:705-18.

219. Pfirrmann CW, Metzdorf A, Zanetti M, Hodler J, Boos N. Magnetic resonance classification of lumbar intervertebral disc degeneration. Spine. 2001;26(17):1873-8. 
220. Griffith JF, Wang Y-XJ, Antonio GE, Choi KC, Yu A, Ahuja AT, et al. Modified Pfirrmann grading system for lumbar intervertebral disc degeneration. Spine. 2007;32(24):E708-12.

221. Thompson JP, Pearce RH, Schechter MT, Adams ME, Tsang IK, Bishop PB. Preliminary evaluation of a scheme for grading the gross morphology of the human intervertebral disc. Spine. 1990;15(5):411-5.

222. Romeis B. Mikroskopiche Technik. Munchen: Oldenburg; 1968.

223. Weigert C. On a staining method for elastic fibers. Zentralbl Allg Pathol Anat (Jena). 1898;9:289-92.

224. de Oliveira F, de Vasconcellos Fontes RB, da Silva Baptista J, Mayer WP, de Campos Boldrini S, Liberti EA. The connective tissue of the adductor canal--a morphological study in fetal and adult specimens. J Anat. 2009;214(3):388-95.

225. Junqueira LC, Cossermelli W, Brentani R. Picrosirius staining plus polarization microscopy: a specific method for collagen detection in tissue sections. J Histochem. 1979;11:447-55.

226. Fullmer HM, Sheetz JH, Narkates AJ. Oxytalan connective tissue fibers: a review. J Oral Pathol. $1974 ; 3(6): 291-316$.

227. Fontes RB, Saad F, Soares MS, de Oliveira F, Pinto FC, Liberti EA. Ultrastructural study of the filum terminale and its elastic fibers. Neurosurgery. 2006;58(5):978-84; discussion 978-84.

228. Gruber HE, Hanley EN. Analysis of aging and degeneration of the human intervertebral disc. Comparison of surgical specimens with normal controls. Spine. 1998 Apr 1;23(7):751-7.

229. Ricard-Blum S. The Collagen Family. Cold Spring Harbor Perspectives in Biology. 2010 Dec;3(1):a004978-a004978.

230. Mosedale DE, Metcalfe JC, Grainger DJ. Optimization of immunofluorescence methods by quantitative image analysis. J Histochem Cytochem. 1996 Sep;44(9):1043-50.

231. Lehr HA, van der Loos CM, Teeling P, Gown AM. Complete chromogen separation and analysis in double immunohistochemical stains using Photoshop-based image analysis. J Histochem Cytochem. 1999 Jan;47(1):119-126.

232. Boenisch T, Farmillo A. Handbook of immunochemical staining methods. 3rd ed. Carpinteria, Estados Unidos: Dako Corporation; 2001.

233. Walker RA. Quantification of immunohistochemistry--issues concerning methods, utility and semiquantitative assessment. Histopathology. 2006 Oct;49(4):406-10.

234. Neumann M, Gabel D. Simple Method for Reduction of Autofluorescence in Fluorescence Microscopy. Journal of Histochemistry \& Cytochemistry. 2002 Mar;50(3):437-9.

235. Hoell T, Huschak G, Beier A, Hüttmann G, Minkus Y, Holzhausen HJ, et al. Auto fluorescence of intervertebral disc tissue: a new diagnostic tool. Eur Spine J. 2006 Aug;15(S3):345-53.

236. Matkowskyj KA, Schonfeld D, Benya RV. Quantitative Immunohistochemistry by Measuring Cumulative Signal Strength Using Commercially Available Software Photoshop and Matlab. Journal of Histochemistry \& Cytochemistry. 2000 Feb;48(2):303-11. 
237. Collins T. ImageJ for microscopy. Biotech. 2007 Jul;43(S1):S25-S30.

238. Zar J. Biostatistical analysis. 4th ed. Upper Saddle River, N.J.: Prentice Hall; 1999.

239. Gruber HE, Ingram J, Hanley EN. An improved staining method for intervertebral disc tissue. Biotech Histochem. 2002 Mar;77(2):81-3.

240. Vernon-Roberts B, Moore RJ, Fraser RD. The natural history of age-related disc degeneration: the pathology and sequelae of tears. Spine. 2007 Dec 1;32(25):2797-804.

241. Siivola SM, Levoska S, Tervonen O, Ilkko E, Vanharanta H, Keinänen-Kiukaanniemi S. MRI changes of cervical spine in asymptomatic and symptomatic young adults. Eur Spine J. 2002 Aug;11(4):358-63.

242. Okada E, Matsumoto M, Fujiwara H, Toyama Y. Disc degeneration of cervical spine on MRI in patients with lumbar disc herniation: comparison study with asymptomatic volunteers. Eur Spine J. 2010 Dec;20(4):585-91.

243. Shamji MF, Setton LA, Jarvis W, So S, Chen J, Jing L, et al. Pro-inflammatory cytokine expression profile in degenerative and herniated human intervertebral disc tissues. Arth Rheum. 2010;62:1974-82.

244. Lee S, Moon CS, Sul D, Lee J, Bae M, Hong Y, et al. Comparison of growth factor and cytokine expression in patients with degenerated disc disease and herniated nucleus pulposus. Clin Biochem. 2009 Oct;42(15):1504-11.

245. Martini DT, De Campos Boldrini S, De Vasconcellos Fontes RB, Liberti EA. Ultrastructural study of the temporomandibular joint after unilateral meniscectomy in Wistar rats. J Oral Rehabil. 2006;33(10):722-8.

246. Kaemmer D, Bozkurt A, Otto J, Junge K, Klink C, Weis J, et al. Evaluation of tissue components in the peripheral nervous system using Sirius red staining and immunohistochemistry: $A$ comparative study (human, pig, rat). Journal of Neuroscience Methods. 2010 Jun;190(1):112-6.

247. Hadi AM, Mouchaers KTB, Schalij I, Grunberg K, Meijer GA, Vonk-Noordegraaf A, et al. Rapid quantification of myocardial fibrosis: A new macro-based automated analysis. Anal Cell Pathol (Amst) [Internet]. 2010 Oct 26;Available from: http://www.ncbi.nlm.nih.gov/pubmed/20978317 [2011 Jul 01].

248. Yu J, Tirlapur U, Fairbank J, Handford P, Roberts S, Winlove CP, et al. Microfibrils, elastin fibres and collagen fibres in the human intervertebral disc and bovine tail disc. J Anat. 2007;210(4):460-71.

249. Cloyd JM, Elliott DM. Elastin content correlates with human disc degeneration in the anulus fibrosus and nucleus pulposus. Spine. 2007 Aug 1;32(17):1826-31.

250. Inoue H, Takeda T. Three-dimensional observation of collagen framework of lumbar intervertebral discs. Acta Orthop Scand. 1975 Dec;46(6):949-56. 
Anexos 
Anexo A

Tabela A.1 - Resumo da alocação dos cadáveres.

\begin{tabular}{|c|c|c|c|c|c|}
\hline Cadáver & RM & Macroscopia & Histologia & MEV & IHC \\
\hline \multicolumn{2}{|c|}{ Grupo Jovem } & & & & \\
\hline $300 / 08$ & & + & + & & \\
\hline $314 / 08$ & & + & + & & \\
\hline $479 / 08$ & + & + & + & & \\
\hline $2780 / 08$ & & + & + & + & + \\
\hline 2781/08 & + & + & + & & \\
\hline $2788 / 08$ & & + & + & + & \\
\hline $6040 / 08$ & & + & + & + & \\
\hline $9386 / 08$ & & + & + & & \\
\hline $11243 / 08$ & & + & + & & \\
\hline $11250 / 08$ & & + & + & & \\
\hline $1767 / 09$ & & + & + & & \\
\hline $4410 / 09$ & + & + & + & & + \\
\hline $4413 / 09$ & & + & + & & \\
\hline $5050 / 09$ & + & + & + & & \\
\hline $5091 / 09$ & + & + & + & & + \\
\hline
\end{tabular}

\section{Grupo Idoso}

\begin{tabular}{|c|c|c|c|c|c|}
\hline $320 / 08$ & & + & + & & \\
\hline $321 / 08$ & & + & + & & \\
\hline $323 / 08$ & & + & + & & \\
\hline $478 / 08$ & & + & + & + & \\
\hline $482 / 08$ & & + & + & + & \\
\hline $2786 / 08$ & & + & + & & \\
\hline $2787 / 08$ & & + & + & & \\
\hline $2789 / 08$ & & + & + & + & \\
\hline $2790 / 08$ & + & + & + & & \\
\hline $5981 / 08$ & & + & + & & \\
\hline $6042 / 08$ & & + & + & & + \\
\hline $8354 / 08$ & + & + & + & & + \\
\hline $8356 / 08$ & + & + & + & & \\
\hline $8358 / 08$ & + & + & + & & + \\
\hline $4411 / 09$ & + & + & + & & \\
\hline
\end{tabular}




\section{Anexo B}

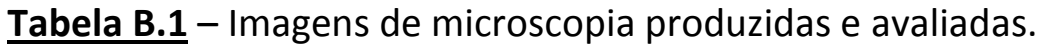

\section{Histologia}

\begin{tabular}{ccccc} 
Fragmentos / cadáver & Colorações $^{1}$ & Cadáveres & Total \\
\hline 10 & 5 & 30 & $=$ & 1500
\end{tabular}

\section{Imuno-histoquímica}

\begin{tabular}{cccccc} 
Fragmentos / cadáver & Séries $^{2}$ & Cadáveres & Campos & & Total \\
\hline 10 & 10 & 6 & 10 & $=$ & 6000
\end{tabular}

Total geral

NOTAS: $1-\mathrm{HE}$, Picro-Sirius (sob luz normal e polarizada), Verhoeff e Weigert 2 - Incluídos os 8 anticorpos e 2 controles negativos 